\title{
O coronel e o lobisomem nas veredas da literatura regionalista brasileira
}

\author{
Naiara Alberti Moreno
}

\section{SciELO Books / SciELO Livros / SciELO Libros}

MORENO, NA. O coronel e o lobisomem nas veredas da literatura regionalista brasileira [online]. São Paulo: Editora UNESP; São Paulo: Cultura Acadêmica, 2015, 290 p. ISBN 978-85-7983-675-6. Available from SciELO Books $<$ http://books.scielo.org $>$.

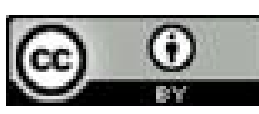

All the contents of this work, except where otherwise noted, is licensed under a Creative Commons Attribution 4.0 International license.

Todo o conteúdo deste trabalho, exceto quando houver ressalva, é publicado sob a licença Creative Commons Atribição 4.0.

Todo el contenido de esta obra, excepto donde se indique lo contrario, está bajo licencia de la licencia Creative Commons $\underline{\text { Reconocimento 4.0. }}$ 


\section{- CORONEL \\ E O LOBISOMEM \\ NAS VEREDAS \\ DA LITERATURA \\ REGIONALISTA \\ BRASILEIRA}

NAIARA ALBERTI MORENO 


\section{O CORONEL E O \\ LOBISOMEM NAS VEREDAS \\ DA LITERATURA \\ REGIONALISTA BRASILEIRA}


CONSELHO EDITORIAL ACADÊMICO

Responsável pela publicação desta obra

Prof. Dr. Adalberto Luís Vicente

Prof. Dr. Brunno Vinicius Gonçalves Vieira

Profa. Dra. Juliana Santini 
NAIARA ALBERTI MORENO

\section{O CORONEL E O \\ LOBISOMEM NAS VEREDAS \\ DA LITERATURA \\ REGIONALISTA BRASILEIRA}

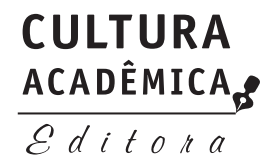


(C) 2015 Cultura Acadêmica

\section{Cultura Acadêmica}

Praça da Sé, 108

01001-900 - São Paulo - SP

Tel.: (0xx11) 3242-7171

Fax: (0xx11) 3242-7172

www.culturaacademica.com.br

www.livrariaunesp.com.br

feu@editora.unesp.br

CIP - Brasil. Catalogação na publicação

Sindicato Nacional dos Editores de Livros, RJ

\section{M836c}

Moreno, Naiara Alberti

O coronel e o lobisomem nas veredas da literatura regionalista brasileira [recurso eletrônico] / Naiara Alberti Moreno. - 1.ed. - São Paulo: Cultura Acadêmica, 2015.

Recurso digital

Formato: epub

Requisitos do sistema: Adobe Digital Editions

Modo de acesso: World Wide Web

ISBN 978-85-7983-675-6 (recurso eletrônico)

1. Carvalho, José Cândido de, 1914-1989. O coronel e o lobisomem.

2. Literatura brasileira - História e crítica. 3. Livros eletrônicos. I. Título.

$15-27114$

CDU: 869.909

CDU: 821.134.3(81)(091)

Este livro é publicado pelo Programa de Publicações Digitais da Pró-Reitoria de Pós-Graduação da Universidade Estadual Paulista "Júlio de Mesquita Filho" (UNESP)

Editora afiliada:

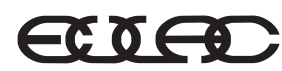

Asociación de Editoriales Universitarias de América Latina y el Caribe

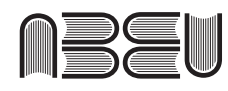

Associação Brasileira de Editoras Universitárias 
Aos meus pais, Maria Cleusa e Galdino, minha fortaleza. A Juliana Santini, meu exemplo. 


\section{Agradecimentos}

Agradeço à professora doutora Juliana Santini, pela orientação amiga, nos estudos e na vida.

Aos professores doutores Ivan Marques, Luiz Gonzaga Marchezan e Sylvia Telarolli, pelas leituras e contribuições decisivas ao desenvolvimento deste trabalho.

Ao professor doutor Márcio Roberto Pereira, por ter sugerido a leitura do romance que é assunto desta reflexão.

Ao professor doutor Benedito Antunes, pela orientação inicial, dedicada e acolhedora, e aos demais professores que participaram desta jornada acadêmica, aos quais também devo minha formação.

Aos amigos que acompanharam esta trajetória, pelo carinho.

À Fapesp, pelo financiamento imprescindível à realização deste trabalho, e à Editora Unesp, por esta publicação. 
Só sei que há mistérios demais, em torno dos livros e de quem os lê e de quem os escreve; mas convindo principalmente a uns e outros a humildade. [...] Às vezes, quase sempre, um livro é maior que a gente.

João Guimarães Rosa (1969, p.160) 


\section{SUMÁRIO}

Introdução 13

1 No "mato brabo da ficção" de José

Cândido de Carvalho 23

O coronel e o lobisomem no "mato brabo" da

ficção de José Cândido de Carvalho 23

O mundo mudou de roupa e penteado... e o romance regionalista também? 46

2. O lobisomem nas veredas da literatura regionalista brasileira: impasses da fortuna crítica de

O coronel e o lobisomem 83

O lugar de $O$ coronel e o lobisomem segundo

a historiografia literária 84

O lobisomem no sertão: regionalismo e insólito nos estudos críticos de $O$ coronel e o lobisomem 105

3 Um lobisomem na periferia do capitalismo 171 Ponciano somos nós 171 
12 NAIARA ALBERTI MORENO

Subdesenvolvimento e literatura

regionalista 186

Super-regionalismo e transculturação

narrativa: a convergência de

conceitos 199

O mundo mágico de $O$ coronel e o

lobisomem 210

Um lobisomem entre o sertão e a cidade:

modernização, mito e identidade 249

Considerações finais 265

Anexos 273

Referências bibliográficas 279 


\section{INTRODUÇÃO}

O romance $O$ coronel e o lobisomem, do escritor brasileiro José Cândido de Carvalho (1914-1989), a despeito de completar meio século de publicação em 2014, parece permanecer, de certo modo, deslocado no panorama da historiografia literária nacional. Lançado em 1964, o livro esteve entre as obras de ficção mais vendidas do Brasil no início da década de 1970, momento em que recebeu maior atenção por parte da crítica literária. Entretanto, passado esse período de visibilidade, a crítica literária deixou-o um tanto à margem de suas preocupações e, voltando seus holofotes à produção espantosa de João Guimarães Rosa, permitiu que questões profícuas e espinhosas, suscitadas pelo romance de José Cândido, ficassem pendentes de discussão. Diante disso, no momento em que se comemoram conjuntamente o cinquentenário de publicação de $O$ coronel e o lobisomem e o centenário do nascimento de seu autor, este estudo almeja, também como forma de homenagem, reanimar o debate crítico instaurado acerca da obra, bem como proporcionar-lhe novas perspectivas de leitura.

A desconfiança inicial, motivadora deste trabalho, surgiu do reconhecimento de um diálogo estimulante entre $O$ coronel e o lobisomem e o primeiro romance do autor, Olha para o céu, Frederico!, obra publicada em 1939. Suspeitava-se que esses romances, distanciados 
no tempo por um intervalo de 25 anos entre suas publicações, dialogassem com a corrente literária do regionalismo brasileiro, mas assumindo direcionamentos e contornos distintos: enquanto o primeiro romance parecia se aproximar do ideário estético predominante na prosa dos anos 1930 - sendo, por isso, frequentemente associado pela crítica à produção ficcional do ciclo da cana-de-açúcar de José Lins do Rego -, o segundo aparentava vincular-se, principalmente, à renovação representacional e estilística inaugurada pela prosa de João Guimarães Rosa, em meados de 1940, período do chamado super-regionalismo (Candido, 1989). Sustentando essa hipótese encontra-se a ideia de que a prosa de José Cândido teria passado, do primeiro para o segundo romance, por uma transformação essencial em seu modo de representar: a narrativa do primeiro livro é realista e mimética, enquanto a do segundo parece assumir uma dimensão insólita e irrealista. Desse modo, toda a reflexão que se desenvolve a seguir está direcionada à tarefa de compreender se a modificação do paradigma de representação observado no interior da produção romanesca de José Cândido pode ser vista, em parte, como uma metonímia de um processo maior, pelo qual passa a própria literatura brasileira, ao transitar de um regionalismo de inclinação mimético-realista (uma constante do romance de 1930) para outro de dimensão mítico-popular (característico dos anos 1950).

Como é possível entrever, a averiguação dessa proposição torna-se uma tarefa complexa na medida em que abrange vários aspectos: o projeto estético de um autor em específico, com destaque à sua produção romanesca; a interpretação da crítica sobre esse projeto ou sobre as obras isoladamente, uma vez que são poucos os trabalhos que se preocuparam em situar o romance focalizado como parte de uma produção autoral maior; o diálogo desse projeto estético com os de outros autores da literatura brasileira; a interpretação da crítica sobre esses diálogos e sobre esses outros autores; e, finalmente, a avaliação da pertinência das categorias críticas utilizadas pelos estudiosos para pensar tanto esses ficcionistas, quanto os períodos estéticos aos quais eles costumam ser associados. Uma vez que o desenvolvimento de cada um desses pontos referentes à tese central 
da proposta implica ainda inúmeros desdobramentos, pode-se antecipar que a discussão ora apresentada adquiriu uma proporção e um alcance maiores do que o previsto inicialmente. Com isso, quer-se dizer que a reflexão sobre esse romance em específico expandiu-se a outros territórios e domínios mais amplos da ficção e da crítica literária, contribuindo, inclusive, para ressignificar obras e conceitos à sua luz.

Um primeiro impasse instaura-se, então, ao se buscar o sentido do romance $O$ coronel e o lobisomem no conjunto da produção de José Cândido de Carvalho. Reconheceu-se a necessidade desse exame pela seguinte razão: sendo o intuito central desta proposta realizar uma leitura do romance em vista de sua possível relação com um determinado período estético da literatura brasileira, pareceu coerente, antes de mais nada, tentar compreendê-lo também como parte do universo de criação de seu próprio escritor, o universo de criação de José Cândido de Carvalho. Como se trata de um autor um tanto esquecido pelos estudos literários, deu-se ainda um passo atrás, em direção aos bastidores da ficção, para elucidar questões acerca da carreira literária e da vida intelectual de José Cândido, informações que se mostraram posteriormente úteis ao entendimento da cosmovisão expressa pelo romance. Desse modo, ao longo da discussão, outros materiais para além do romance corpus da pesquisa (demais livros do autor, textos publicados na imprensa, entrevistas, depoimentos, biografias etc.) são convocados para, quando necessário, esclarecer, embasar ou justificar o caminho de análise adotado, de modo a favorecer uma visão global e coesa de sua produção. Desse percurso, surgiram, inclusive, como se verá, as maiores surpresas deste estudo. Finalmente, com esse movimento de retorno à biografia e ao restante da produção do autor, espera-se também contribuir para a divulgação de sua obra, sobretudo da parte que continua relegada aos jornais e distante da reflexão crítica, a fim de incentivar novas pesquisas capazes de redescobrir esse universo ficcional ainda pouco explorado e bastante profícuo.

Ao percorrer o território da produção ficcional de José Cândido de Carvalho, manteve-se o cuidado, no entanto, de não perder de 
vista o romance que motivou a apresentação desse universo. Por isso, no primeiro capítulo deste livro, propõe-se a reconstrução do panorama da recepção crítica de $O$ coronel e o lobisomem pela imprensa. $\mathrm{O}$ intuito é mostrar quais foram as primeiras impressões críticas manifestadas a respeito da obra, a fim de compreender as tendências de leitura que posteriormente se constituíram, acerca do romance, no âmbito da historiografia literária e dos estudos críticos específicos. Porém, entre a reconstituição genérica da recepção da obra, feita no início do primeiro capítulo, e a apresentação verticalizada de alguns de seus estudos críticos, feita no segundo, optou-se por realizar uma leitura contrastiva entre os dois romances do autor. O interesse do estabelecimento desse paralelo entre os romances foi o de determinar, para além das semelhanças que compartilham, também os eixos temáticos e formais que os distanciam, verificando, assim, em que resultou, textualmente, o afastamento temporal existente entre as obras. Para tanto, essa comparação foi realizada de modo propositalmente descomprometido com os juízos da crítica, de maneira que estes só foram convocados à análise na medida em que confirmavam as considerações a que se chegava, partindo do contraste dos textos em si. Com isso, procurou-se não condicionar demasiadamente o resultado das considerações a um olhar já predeterminado pela crítica, mas antes observar como os textos dialogavam com a hipótese de transição aqui levantada. Considerou-se também pertinente para a consecução dessa etapa a ênfase à dimensão histórica e geográfica que as narrativas trazem como pano de fundo das ações. Finalmente, deve-se esclarecer que o enfoque da leitura, nesse momento, incidiu prioritariamente sobre o romance de 1939, já que a análise do outro é retomada ao final do trabalho.

Na sequência, a partir dos resultados obtidos pelo confronto entre as obras, passa-se a outro aspecto dorsal da proposta: a investigação da fortuna crítica do romance $O$ coronel e o lobisomem. Essa etapa corresponde ao segundo capítulo, que se divide em duas partes. A primeira delas destina-se a sondar e questionar a validade daquilo que leria, sobre o romance de José Cândido, quem nesta altura consultasse obras de referência da historiografia literária brasileira. Já a 
segunda parte volta-se a um número mais restrito de estudos críticos do romance, selecionados em função da verticalidade que demonstram em relação aos eixos de análise aqui propostos, confirmados pela leitura comparativa das obras, a saber, a presença do insólito na narrativa de 1964 e a sua inscrição na tradição regionalista da literatura brasileira. Os estudos em que se encontraram as abordagens mais aprofundadas desses aspectos - embora apresentem enfoques diferentes - são dos pesquisadores José Hildebrando Dacanal (1970), Regina Zilberman (1977) e Zilá Bernd (1998). Igualmente, partindo dos resultados alcançados com a comparação das obras, mas também os ampliando com a problematização dessas perspectivas analíticas e com a observação de questões ainda em suspenso tanto pela crítica quanto pela historiografia literárias, propõe-se, enfim, uma abordagem revitalizada à leitura do romance.

Assim, feito no segundo capítulo o levantamento crítico do estado da questão, desenvolve-se, finalmente, no terceiro, uma proposta autoral de leitura do romance: a hipótese que aqui se levanta é a de que essa narrativa, entre outras leituras possíveis, possa ser interpretada pela capacidade de comportar uma imagem do Brasil, mais especificamente do Brasil da década de 1950. Na continuação do capítulo, confirma-se a viabilidade dessa leitura ao se discutir as relações entre regionalismo literário e subdesenvolvimento, assim como também entre os conceitos de "super-regionalismo" (Candido, 1989) e "transculturação narrativa" (Rama, 2004). Dessa forma, procurou-se analisar o romance questionando as implicações da articulação de vozes do discurso crítico latino-americano, que se revelaram fundamentais à compreensão das fases do regionalismo literário brasileiro.

Foram comentadas ainda proposições de alguns estudos - (Ianni, 1991; Spindler, 1993; Caymad-Freixas, 1998; Moretti, 1996) - que compartilham, indiretamente, das bases dessa perspectiva crítico-teórica, segundo a qual o romance latino-americano de meados do século XX se caracteriza pela imbricação de um plano histórico e realista a outro inverossímil, inclinado ao mítico, tal como se visualiza em $O$ coronel e o lobisomem. Como denominador comum 
dessas propostas, encontra-se, grosso modo, a ideia de que um estilo artístico, uma tendência literária, é capaz de revelar e - o mais importante - reinventar o espírito histórico de uma época. Assim, privilegiou-se a discussão sobre os sentidos da dimensão fantasiosa do romance, a tradição da figura do contador de histórias e os conflitos culturais que aparecem sob a perspectiva do homem do campo.

$\mathrm{Na}$ continuação, como último movimento de análise do romance, é apresentada uma leitura pormenorizada do percurso do herói ao transitar do espaço rural para o urbano e, por consequência, do modo como se conforma seu processo de decadência. Nessa parte final, perpassa-se um viés de análise bastante profícuo a obras que, como $O$ coronel e o lobisomem, podem ser consideradas narrativas dos processos de modernização da América Latina. A sugestão final, que convida a uma abordagem diferenciada do romance, considera o retorno do mito fáustico, por uma perspectiva alegórica, em sua relação intrínseca com os processos de modernização representados pelas literaturas periféricas.

Como um adendo a essa introdução, cumpre esclarecer a adoção de uma perspectiva que subjaz a toda a discussão que se segue: deve-se dizer, de antemão, que se considera aqui pertinente e proveitosa a utilização do conceito de regionalismo no âmbito dos estudos literários. Como tal noção é crucial aos objetivos deste livro, pois dela advém as bases da proposição que se pretende comprovar, foi preciso problematizá-la e estudá-la previamente. Essa perspectiva foi adotada, portanto, somente depois de ter sido uma das primeiras preocupações da pesquisa. Desse modo, vale explicitar, à guisa de introdução, algumas das questões convocadas pelo conceito, as quais serão posteriormente retomadas a fim de aclarar o romance.

Nesse sentido, sabe-se que o regionalismo se apresenta como um conceito complexo e multifacetado, que permeia a compreensão da literatura nacional desde o seu processo de formação até as produções contemporâneas. No âmbito da historiografia literária, o termo filia-se à questão do nacionalismo e à dialética entre o aproveitamento de sugestões locais e a incorporação de modelos importados. Desse modo, a tendência regionalista, tomada como uma das dominantes 
estilísticas do romance brasileiro, percorre estágios decisivos no processo de formação e consolidação da literatura nacional, tais como o sertanismo romântico, o pré-modernismo, o ciclo de romances do nordeste e, ainda, o chamado "super-regionalismo" (Candido, 1989), assumindo feições e contornos peculiares ao longo do tempo.

Não obstante, poucos são os estudos que se ocuparam em pensar a transformação da prosa regionalista sem incorrer nas armadilhas que apenas recentemente têm sido superadas pela crítica, tais como considerar o regionalismo de modo reducionista e simplista em oposição ao universalismo ou, ainda, tomá-lo como um movimento datado, estático e uniforme, negando seu caráter proteico e suas constantes transformações. "Campo minado de preconceitos" (Chiappini, 1995, p.156), o regionalismo foi por muito tempo rechaçado pela crítica que, ou o desconsiderava, ou demonstrava resistência em admiti-lo enquanto tendência literária válida. Nessa perspectiva, o termo adquiriu uma conotação negativa, e mesmo pejorativa, visto que fora associado e reduzido à representação pitoresca e exótica, sendo, por isso, acusado pelo caráter supostamente localista, limitador e anacrônico. Assim, a crítica esquivou-se por muito tempo ao termo e às suas implicações, demonstrando certa relutância em avaliar as produções de cunho regional, ou analisando- as de modo a ignorar essa dimensão.

Contudo, segundo Chiappini, o regionalismo não pode ser compreendido como um movimento fechado em si mesmo e em um dado período histórico, mas como uma tendência mutável que persiste ao longo do tempo, adquirindo matizes diferenciados de acordo com as conjunturas contextuais e com os recursos estilísticos das respectivas épocas em que se manifesta (Chiappini, 1995, p.157). Essa ponderação aponta para a exigência de que também os paradigmas de interpretação utilizados pela crítica sejam repensados continuamente, caso a caso, a fim de se adequarem mais plenamente a essa produção desafiadora em constante renovação: "A persistência da gaffe ou 'praga' ao longo do tempo, por si só, deveria fazer a crítica desconfiar de que há mais mistérios no regionalismo do que pretende a nossa vã pressa de ser modernos" (Chiappini, 1994, p.701). 
Desse modo, acredita-se que superar essa carga de preconceitos cristalizados em torno do regionalismo favoreceria uma melhor compreensão dos diálogos que se estabelecem dentro da tradição regional. Isso é o que propõe, por exemplo, o pesquisador André Tessaro Pelinser ao constatar certo "apagamento", por parte da crítica, das marcas regionais de autores consagrados, como ocorre com a obra de Guimarães Rosa, que costuma ser vista apenas em diálogo com escritores do cânone internacional: "Confiamos na pertinência de revisar criticamente uma argumentação que, como se percebe, esconde a afinidade entre muitas obras, mormente no que tange à relação da produção rosiana com boa parte da escrita nacional" ( $\mathrm{Pe}$ linser, 2010, p.111).

De fato, leituras que busquem estabelecer vínculos de nossa produção com a literatura canônica ocidental cumprem, seguramente, com um papel importante da crítica; assim, Rosa é comparado a Joyce e José Cândido a Cervantes, contudo, ao se desconsiderar o caráter regional da obra desses autores nacionais, dificulta-se o reconhecimento dos diálogos que estabelecem entre si e, portanto, a compreensão de um momento específico da literatura brasileira. Guardadas as devidas proporções, pode-se reconhecer entre o romance de Rosa e o de José Cândido um denominador comum: ambos estariam num mesmo período, após o realismo típico do romance de 1930, escrevendo ficção regionalista - compreendida como aquela que apresenta ambientação, temas e personagens do campo - eivada de elementos insólitos.

Em síntese, com a leitura de uma ampla bibliografia sobre o regionalismo literário, foi possível perceber que, apesar da polêmica ser tamanha que se chegue a questionar a legitimidade do conceito, há uma crítica relativamente recente empenhada em redimensionar a discussão e apontar os prejuízos de se ignorar ou menosprezar essa dimensão presente em muitos romances nacionais. Ao que se constatou, o maior problema decorre do fato do termo "regionalismo" ter sido tomado em oposição a "universalismo", no sentido do alcance das obras, como se uma obra regionalista pudesse não interessar a pessoas de ambientes outros que não o retratado ou, ainda, que 
serviria àqueles leitores apenas como atrativo pelo exótico e pitoresco. Essa compreensão está pautada no reconhecimento de uma dialética entre local e universal, que auxiliou a compreender um momento de formação e afirmação da literatura nacional, então empenhada em mostrar o que possuía de singular e construir um passado heroico a seu povo. Além disso, em outro momento passou-se a associar os romances de espaço urbano à profundidade psicológica e os de espaço rural à superficialidade e tipificação.

Porém, como será demonstrado, não é nesse sentido que a questão deveria ser compreendida em relação aos romances de José Cândido, assim como também em relação a obras como São Bernardo, Fogo morto, Grande sertão: veredas e tantas outras que conseguem representar dramas psicológicos e existenciais conciliando-os à ambientação rural e às suas implicações específicas. Como exemplo máximo dessa conjunção na obra de José Cândido, pode-se afirmar que O coronel e o lobisomem trata, em última análise, do mesmo assunto dos grandes romances ocidentais: o desajuste do homem frente ao mundo que o cerca. No entanto, é preciso lembrar que esse desajuste do protagonista é desencadeado por um conflito econômico, social e cultural específico, que se relaciona ao processo de modernização do país. Assim, a problemática regional do romance não aparece apenas enquanto "moldura" ou pano de fundo da história, mas, ao contrário, mostra-se substancial à construção da narrativa, uma vez que há um conflito expressivo entre o espaço rural e o espaço urbano. É isso o que se verá a seguir, ao se percorrer as veredas trilhadas por esse lobisomem entre o campo e a cidade. 


\section{1 \\ No "MATO BRABO DA FICÇÃO" DE José Cândido de Carvalho}

\section{O coronel e o lobisomem no "mato brabo" da ficção de José Cândido de Carvalho}

Em contraste com a recepção pouco calorosa da estreia de José Cândido de Carvalho (1914-1989), com o livro Olha para o céu, Frederico!, de 1939, seu romance O coronel e o lobisomem obteve, desde o lançamento, em 1964, o reconhecimento tanto do público quanto da crítica, que logo o consagraram como obra-prima da literatura brasileira. O caminho dos originais à versão impressa do livro, no entanto, não foi simples: o romance estava pronto há algum tempo, mas houve dificuldades em encontrar uma editora que o avaliasse e o publicasse sem longa demora. A José Olympio estava com a programação de lançamentos completa para cerca de dois anos e a Civilização Brasileira, também consultada, demorava a emitir um parecer sobre a obra. ${ }^{1}$ Ansioso por ver o livro publicado, José Cândido desistiu de aguardar o lançamento por uma editora de maior notoriedade na divulgação de romances e entregou os originais às oficinas de $\mathrm{O}$

1 Cf. o discurso de Herberto Sales na cerimônia de recepção de José Cândido de Carvalho à Academia Brasileira de Letras, em 1º de outubro de 1974 (Sales, 1983, p.312). 
Cruzeiro, empresa famosa pela edição da revista homônima, para a qual o autor trabalhava desde 1957, e que publicava alguns títulos sob a direção de seu amigo, Herberto Sales. Assim, o livro composto em março de 1964, pelas Edições O Cruzeiro, chegava às livrarias em maio, com uma tímida tiragem de 3.000 exemplares, que se esgotou em cerca de quatro meses. ${ }^{2}$

A recepção crítica da obra pelos jornais foi imediata e entusiasta: o crítico Lago Burnett, poucos dias após a estreia, comentou seu enredo na coluna Literatura do Jornal do Brasil (14 maio 1964, Caderno B, p.3); Eneida de Morais a apresentou em Autor e Livro da Semana, no Suplemento Literário do Diário de Notícias (28 jun. 1964, p.2); sobre ela, também Wilson Martins escreveu um artigo intitulado "Uma obra-prima", na coluna Últimos Livros do Suplemento Literário d'O Estado de S. Paulo (11 jul. 1964, p.2); Herculano Pires publicou uma resenha seriada em Mundo dos Livros, Diário da Noite (28 e 29 jul. 1964, Caderno 2, p.8 e p.6, respectivamente); Leo Gilson Ribeiro, em Caminhos da Cultura, do Suplemento Literário do Diário de Notícias (13 set. 1964, p.2), afirmou ser esta "a surpresa mais agradável no setor da prosa brasileira de que temos notícia desde o encontro decisivo com a obra de Guimarães Rosa”; Hélio Pólvora a incluiu na análise dos romances mais importantes do ano, em "Lobisomem e Clarice no balanço", publicada na coluna Literatura, no Diário Carioca (20 e 21 dez. 1964, p.9).

Apesar da pouca eficiência do sistema de distribuição das Edições O Cruzeiro - uma vez que o foco editorial do grupo eram as revistas e não os livros -, o romance recém-lançado passou a figurar também, ainda que esporadicamente, entre as primeiras posições nas Preferências do Leitor, conforme enquetes semanais promovidas pelo Departamento de Relações Públicas da Distribuidora Nacional de Livros Ltda. (Correio do Paraná, 12 jul. 1964, p.6 e 27

2 Uma nota publicada no Jornal do Brasil, em 25 de novembro de 1964 (Caderno B, Literatura, p.3) anunciou o esgotamento do livro e o projeto de nova edição para o ano seguinte. 
set. 1964, p.8). ${ }^{3}$ Somando-se à acolhida da obra, vieram, então, os prêmios: Jabuti, da Câmara Brasileira do Livro, Luísa Cláudio de Sousa, do Pen Clube do Brasil, e Coelho Neto, da Academia Brasileira de Letras.

Após a publicação da segunda edição, em outubro de 1965, com uma tiragem de 10.000 exemplares, também pela editora $\mathrm{O}$ Cruzeiro - que agora exibia na contracapa os elogios de Nelson Werneck Sodré, Josué Montello, Marques Rebelo, Rachel de Queiroz e Cavalcanti Proença -, seria a vez da José Olympio passar a editar o romance. Assim, em outubro de 1970, era publicada, na prestigiada Coleção Sagarana, a terceira edição do livro, com estudos de Cavalcanti Proença, Wilson Martins e ilustrações de Poty. Na orelha, lia-se "O coronel e o lobisomem consagrado pela crítica" e seguiam-se os elogios de vários escritores. A partir dessa nova edição, a obra conquistou, de fato, visibilidade em relação ao grande público. A aprovação no âmbito das letras exibida nessa edição repercutiu nos jornais, e uma síntese dela foi fornecida pelo jornalista e crítico de arte Luís Martins (1970, p.15), ao elencar, em uma crônica de dezembro de 1970 - portanto, dois meses após a impressão da terceira edição -, os nomes da ficção e da crítica que aclamaram a obra:

Mas que importância tem o que digo, depois de Érico Veríssimo dizer que não hesita "em colocar $O$ coronel e o lobisomem entre os vinte melhores romances da literatura brasileira de todos os tempos"? E Raquel de Queiroz confirmar: "um grande coronel e um grande livro"? E Josué Montello sentenciar: "alcança a linha da obra-prima"? E Marques Rebelo proclamar: "é um dos pontos mais altos a que chegou a literatura brasileira"? E, no mesmo diapasão, opinarem R. Magalhães Junior, Alceu Amoroso Lima, Nelson Werneck Sodré, Adonias Filho? Que ressonância pode ter a minha débil voz nesse impressionante coro de louvores?

3 Repercussão semelhante se verificaria também por ocasião da publicação da segunda edição, segundo dados do Sindicato Nacional dos Editores de Livros, publicados na seção "Os mais vendidos" do Diário de Notícias, em $1^{\circ}$ de maio de 1966, p.3. 
Não importa. O importante é não desafinar. E eu não desafino: O coronel e o lobisomem é, de fato, um grande livro. (Agora em terceira edição.) (O Estado de S. Paulo, 3 dez. 1970, Caderno Geral, Crônica, p.15)

O público leitor, por sua vez, respondia também ao "coro de louvores", de modo que a obra se tornou em pouco tempo um best-seller, conforme afirmou Tavares de Miranda (1971, p.14), em nota "O louvor do lobisomem", de janeiro de 1971: "O grande êxito de livraria no momento é o livro de José Cândido de Carvalho, $O$ coronel e o lobisomem, romance dos tempos da Guarda Nacional, que o crítico Wilson Martins considerou verdadeira obra-prima da literatura brasileira". Dessa popularidade emergente com a edição da José Olympio foram também testemunhas as relações dos livros mais vendidos divulgadas nos jornais, como as publicadas no Jornal do Brasil entre 1971 e 1973, período de intensa presença do romance na imprensa. Todo esse sucesso propiciou, em 1974, a acolhida de José Cândido de Carvalho pela Academia Brasileira de Letras, que o elegeu "imortal", destinando-lhe a cadeira número 31, em sucessão a Cassiano Ricardo.

Tal repercussão nacional projetou o romance ao exterior ainda na década de 1970, quando foi publicado em Portugal (1971), na Argentina (El coronel y el lobisón, trad. Haydeé M. Jofre Barroso, editora Sudamericana, 1976), na França (Le colonel et le loup-garou, trad. José Carlos Gonzales, editora Gallimard, 1978) e na Alemanha (Der Oberst und der Werwolf, trad. Roman Suhrkamp, editora Suhrkamp, 1979). ${ }^{4}$ O livro ganhou também duas adaptações cinematográficas (uma de 1978, que concorreu ao Festival de Cannes, dirigida por Alcino Diniz, e a outra de 2005, sob a direção de Maurício Farias) e duas versões televisivas (a primeira foi produzida pela TV Cultura em 1982, em formato de telerromance, e reformulada

4 Apesar das tentativas de experientes tradutores, a versão em língua inglesa não se concretizou "devido às dificuldades de se encontrar as palavras certas para os personagens naquele idioma” (Jornal do Brasil, $1^{\circ}$ dez. 1974, Caderno RJ, p.4). 
em 1986, como minissérie com mais de 30 capítulos, dirigida por Arlindo Barreto; e a segunda foi realizada em 1994 pela Rede Globo, para a série Brasil Especial, sob direção de Guel Arraes e roteiro de Jorge Furtado). Paralelamente a essa propagação para outras línguas e linguagens, a publicação do romance tornou-se ininterrupta no Brasil, de modo que, atualmente, a obra já se encontra em sua $58^{\mathrm{a}}$ edição, com mais de 400.000 exemplares $^{5}$ impressos apenas pela José Olympio, afora os números de outras empresas que também a editaram, como Círculo do Livro e Rocco.

O sucesso do romance foi tamanho que, paradoxalmente, "apequenou” seu autor. A famosa criação, o coronel Ponciano de Azeredo Furtado, já quase prescindia de seu criador e das outras criaturas ficcionais que lhe eram congêneres. Com isso, José Cândido se tornou conhecido basicamente pelo epíteto "autor de $O$ coronel e o lobisomem". Assim, após o sucesso efervescente na década de 1970 e o falecimento do autor, em 1989, seu nome e o restante de sua produção sofreram um aparente processo de apagamento, responsável, em parte, por intensificar a injusta marca que levaria de ser "escritor de uma obra só". Por isso, a despeito do centenário de seu nascimento, comemorado em 2014, o autor e, por consequência, sua obra (que não se restringe ao aclamado livro) certamente ainda não dispensam apresentação.

Nesse sentido, cumpre expor aqui, ainda que brevemente, informações sobre a vida intelectual de José Cândido de Carvalho e o conjunto de sua obra, visando atender ao propósito deste livro, no que se refere à necessidade de melhor delinear o projeto estético do autor, nele situando seu principal romance. Afinal, se o intuito central desta reflexão é analisar o romance $O$ coronel e o lobisomem tendo em vista as conjunturas de sua produção e sua possível relação com um determinado momento artístico da literatura brasileira, nada mais coerente que, antes, buscar compreendê-lo também como parte do projeto literário do próprio escritor.

5 Valor estimado, considerando-se informações fornecidas pela atual direção editorial da José Olympio, que desde 2001 integra o Grupo Editorial Record. 
Ao longo da discussão, outros materiais que não necessariamente integram o corpus da pesquisa (demais livros do autor, textos publicados na imprensa, entrevistas, depoimentos, biografias etc.) serão convocados para, quando necessário, esclarecer, embasar ou justificar o caminho de análise adotado, de modo a favorecer uma visão global de sua produção. Com isso, espera-se também contribuir para a divulgação de sua obra, sobretudo da parte que continua relegada aos jornais e distante da reflexão crítica, a fim de incentivar novas pesquisas capazes de lançar luz sobre esse universo ficcional ainda pouco explorado pelos estudos literários.

Dessa maneira, convém assinalar, por ora, que o "autor de $O$ coronel e o lobisomem", ao longo de toda sua trajetória, atuou não apenas como romancista e homem de Letras, como costuma ser lembrado, mas também, e principalmente, como homem de imprensa, participando ativamente da vida jornalística do país, tanto que, mesmo após a consagração por seu premiado livro, José Cândido de Carvalho preferia ser chamado de jornalista, como afirmou em várias ocasiões: "Vivo exclusivamente para e do jornalismo e só escrevo [romances] nas folgas" (Carvalho, 1964, p.2); "Sou um jornalista que vez por outra vai ao romance" (1973, p.22); "Sempre fiz jornalismo. [...] Jornalismo é o que gosto de fazer. Faço com um pé nas costas" (1983, p.5).

De fato, José Cândido de Carvalho, fluminense da cidade de Campos dos Goytacazes, desempenhou intensa atividade jornalística, colaborando em diversos e importantes jornais e revistas. ${ }^{6}$ Em sua cidade natal, já em 1930 e com apenas 16 anos, foi revisor do semanário $O$ Liberal, e, a partir disso, passou a exercer funções

6 As informações sobre as atividades profissionais do autor foram consultadas e reorganizadas a partir da comparação entre os seguintes materiais: texto de apresentação do autor, por ele próprio, "JCC: uma história pessoal" e, pela José Olympio, "Sobre o autor” (Carvalho, 2007, p.7-12); estudos críticos e biográficos (Bacega, 1983; Ferreira, 2004; Nina, 2011) e discurso de recepção de José Cândido de Carvalho à Academia Brasileira de Letras (Sales, 1983). Outras informações específicas, provenientes de entrevistas, matérias e notas localizadas em jornais, serão identificadas quando mencionadas. 
de redator e colaborador em periódicos locais, como a Folha do Commercio, que contava com Raimundo Magalhães Júnior, um dos jornalistas mais prestigiados da época, o jornal O Dia, onde passou a comentar política internacional, e ainda a Gazeta do Povo e o Monitor Campista.

Bacharelando-se em Direito em 1937, mudou-se para o Rio de Janeiro e, em 1939, indicado por Vargas Neto (neto de Getúlio Vargas) a Vasco Lima, foi convidado a trabalhar em A Noite, jornal de grande circulação que chegou a publicar impressionantes quatro edições diárias. Nele permaneceria como redator por dezoito anos, assinando, entre outros textos, crônicas humorísticas sobre o conflito da segunda Guerra Mundial, que eram publicadas na coluna Nota Internacional. Mantendo a colaboração nesse jornal, passou a dirigir, em 1943, o diário fluminense $O$ Estado, a convite de seu amigo Amaral Peixoto, então interventor do Estado do Rio. Note-se que ambos os jornais estiveram submetidos ao controle do governo ditatorial de Getúlio Vargas: A Noite fora encampada em 1940, após decreto que a integrava às denominadas Empresas Incorporadas ao Patrimônio Nacional (Fundação..., [s.d.]), enquanto que $O$ Estado fora porta-voz do governo estadual, conforme o próprio escritor afirmara: "Era um jornal do Governo que, portanto, fazia política do Governo. Era um jornal pertencente às Empresas Incorporadas" (Carvalho, 2004, p.81). José Cândido esteve, portanto, desde o princípio de sua atuação na imprensa, integrado a um círculo de figuras influentes na política nacional no período do Estado Novo.

Em 1957, com o fechamento do jornal A Noite pelo novo governo, José Cândido começou a atuar junto aos Diários Associados, corporação que, fundada por Assis Chateaubriand, já foi a maior da história da imprensa brasileira, reunindo numerosos e importantes jornais, revistas, rádios e emissoras de televisão. O princípio de sua participação no grupo ocorreu, quando, a convite de Herberto Sales, tornou-se redator e chefe do departamento de copidesque de $O$ Cruzeiro, revista de maior tiragem do país na época, e na qual permaneceu até seu fechamento, em 1975. Nela assinou a coluna de textos humorísticos $\mathrm{O}$ Impossível Acontece, bem como as seções $\mathrm{O}$ 
Gramofone, que se tornaria Jornal de JCC, e Quem é Você?? dedicada a entrevistas. Além disso, dirigiu a edição internacional da revista e também colaborou como cronista em outros periódicos do grupo: O Jornal, onde assinava a coluna Diário de JCC; e A Cigarra, revista mensal editada pelas oficinas de O Cruzeiro. Entre 1957 e 1959, escreveu crônicas também para o Jornal do Brasil, quando o periódico encontrava-se em fase de revitalização sob a direção de Odylo Costa Filho. Colaborou, ainda, até os últimos meses de vida, com publicações regulares nos periódicos $O$ Fluminense, Revista Nacional e Jornal do Commercio.

Paralelamente a essa intensa atividade jornalística, José Cândido desempenhou cargos públicos que o aproximaram da vida política do país: foi redator do Departamento Nacional do Café (Ministério da Indústria e do Comércio); diretor do Departamento Estadual de Imprensa e Propaganda (DEIP) do Estado do Rio de Janeiro - órgão vinculado ao DIP, maior instrumento coercitivo da liberdade de imprensa durante o Estado $\mathrm{Novo}^{7}$ - e chefe da Divisão de Divulgação da Imprensa Estadual Fluminense. ${ }^{8}$ Sempre bem relacionado com próceres do governo, em 1970, auge da ditadura militar sob o comando do general-presidente Emílio Garrastazu Médici, foi nomeado diretor da Rádio Roquette-Pinto, cargo que ocuparia até 1974, quando passou a assumir a direção do Serviço de Radiofusão Educativa do MEC, a qual deixou em 1976. Ainda nesse período,

7 Essa ocupação, que não é mencionada em suas biografias e textos de apresentação, aparece noticiada no jornal A Noite (2 jun. 1943, p.3), em que se informa: "Por ato do governo do Estado do Rio, foi nomeado para o cargo de diretor da Divisão de Imprensa do DEIP, recentemente criado, o nosso companheiro de redação José Cândido de Carvalho."

8 A respeito dessa nomeação, também noticiada em A Noite (14 fev. 1949, p.3), afirma-se: "Na década seguinte [em 1950] o Diário Oficial fez o que bem se pode considerar sua melhor aquisição no período: a de José Cândido de Carvalho, extraordinário escritor e extraordinária figura humana, nomeado a 14 de fevereiro de 1949 para chefiar a recém-criada Divisão de Divulgação. Seu papel era coordenar a edição de livros que interessavam à história, literatura, ciências e artes do Estado, dando continuidade ao programa que Oliveira Rodrigues vinha executando com louvor desde 1942" (Imprensa..., [s.d.]). 
em 1975, foi eleito presidente do Conselho Estadual de Cultura do Rio de Janeiro, órgão que teve suas atividades encerradas em 1983 pelo então governador estadual Leonel Brizola. Foi também presidente, entre 1976 e 1981, da Fundação Nacional de Arte (Funarte), a convite do ministro Ney Braga; entre 1982 e 1983, do Instituto Municipal de Cultura do Rio de Janeiro (RioArte) e, a partir de 1984, da Fundação de Atividades Culturais de Niterói (FAC), atual Fundação de Arte de Niterói (FAN), em cuja sede se construiu, em 1988, a Sala José Cândido de Carvalho, em sua homenagem.

Mesmo com essa ampla e agitada atuação junto à imprensa e ao serviço público, José Cândido conseguiu desenvolver, para além dos romances mencionados, uma considerável produção ficcional que, na realidade, não necessariamente se opunha ao jornalismo; ao contrário, antes nele se formava e desenvolvia. Desse modo, a partir da imprensa, o escritor circulou por outros gêneros, entre os quais a crônica, a crônica política, o conto, o microconto e a biografia "estilizada", todos eles cultivados com a linguagem e o humor que lhe eram peculiares. Alguns de seus textos nascidos no jornal ganharam o status de permanência que o suporte em livro lhes assegurou. Assim, foram publicados, a partir da década de 1970: Porque Lulu Bergantim não atravessou o Rubicon (1971) e Um ninho de mafagafes cheio de mafagafinhos (1972), ambos com o subtítulo "contados, astuciados, sucedidos e acontecidos do povinho do Brasil"; Ninguém mata o arco-íris (1972), espécie de biografias curtas e criativas a que o autor chamou de "retratos 3x4"; Se eu morrer telefone para o céu (1979); e os títulos Manequinho e o anjo de procissão (1974) e Os mágicos municipais (1984), seleções de contos e crônicas já publicados nos outros livros. No entanto, há ainda muitos outros textos anteriores a esse período que, por alguma razão, não contaram com a mesma intenção, por parte do autor, de constituírem legado à posteridade e, com isso, continuam espalhados nos jornais e revistas nos quais colaborou.

Entre os textos não publicados em livro, foi encontrada, durante a pesquisa realizada para elaboração deste estudo, uma narrativa que importa em especial a esta discussão, e que será analisada mais 
adiante, quando comparada ao romance. Por enquanto, vale esclarecer algumas circunstâncias de sua publicação. Trata-se de uma crônica de 1958 em que aparece, pela primeira vez, a figura de Ponciano de Azeredo Furtado, não como "o coronel”, como conquistou fama e lugar na literatura brasileira, mas como "O Major", título do texto. Ao que consta, essa narrativa, que teria motivado a escrita do romance, permanece ainda inédita em livro, além de não ter sido recuperada para análise pelos estudiosos do autor.

Em 1974, Herberto Sales, o primeiro editor de O coronel e o lobisomem, menciona esse texto em seu discurso de recepção a José Cândido de Carvalho na Academia Brasileira de Letras e conta como a narrativa, de crônica, passou a romance. No entanto, nesse discurso, ao reconstruir uma conversa que tivera há anos com o autor, Sales afirma que a crônica aparece, na fala de José Cândido, com o mesmo título do romance:

[...] continuáveis autor de um único livro. [...] Foi quando, à falta de originais de um novo livro, concordastes, por insistência minha, em supri-la mediante o expediente de uma reunião, em volume, das vossas "historinhas". Combinamos que elas apareceriam sob a designação de "crônicas", gênero de boa tradição editorial no Brasil e para o qual havia um público certo. No fundo, temíamos que a designação de "historinhas" pudesse de alguma forma amofinar o volume. Por fim, um belo dia, me entregastes os originais tantas vezes reclamados. Li o título: O coronel e o lobisomem.

- Mas é um título excelente! - exclamei.

E vós me esclarecestes:

- Tirei-o de uma das minhas crônicas para o Jornal do Brasil. Aliás, é a crônica que abrirá o volume.

Assinamos imediatamente o contrato de edição. Entretanto, como as oficinas de O Cruzeiro estavam com uma avassaladora sobrecarga de trabalho, e em fase de instalação de novas máquinas, os originais dormiram em minha gaveta um longo sono de mais de um ano. E o mais curioso é que vós, ao contrário da maioria dos autores em tais circunstâncias, não demonstráveis nenhuma pressa em ver 
o livro na rua. Uma tarde, porém, entrastes na minha sala para me pedir de volta os originais.

$[\ldots]$

- Calma, rapaz. Seu livro entrará em composição na próxima semana.

- Não se trata disto - me respondestes.

E procurando tranquilizar-me:

- É que resolvi transformar em romance O coronel e o lobisomem. (Sales, 1983, p.311-2)

A referência ao Jornal do Brasil, como o periódico em que a crônica foi publicada, procede; no entanto, o título com que o texto, de fato, se apresentava no jornal não era ainda "O coronel e o lobisomem”, como é mencionado. Se, na época da entrega dos originais, a reunião de crônicas em que o texto sairia já se encontrava sob esse título, José Cândido certamente o havia alterado ao transpô-lo do jornal à compilação. E Sales, por sua vez, talvez tenha se confundido, com a distância de anos, ao atribuir a José Cândido a afirmação de que o título já existia no jornal - talvez, na ocasião, este tenha se referido à existência prévia do texto, não propriamente do referido título. Em todo caso, a crônica "O Major" (ver reprodução em "Anexos") foi localizada no Jornal do Brasil, na edição de 16 de agosto de $1958,1^{\circ}$ Caderno, terceira página. A data da narrativa no jornal e o depoimento de Herberto Sales demonstram que o projeto de transformá-la em romance levaria certo tempo a tomar forma. A figura de Ponciano e seu universo de lobisomens já se desenhavam no imaginário de José Cândido há, portanto, pelo menos seis anos antes de se tornarem famosos em livro.

Retrocedendo ainda mais na produção do autor, é possível encontrar, inclusive, as origens da crônica "O Major", pois parte considerável de seu enredo já havia surgido em 1951, em uma crônica intitulada "A Guerra do Paraguai em pessoa" (ver reprodução em "Anexos"), publicada em A Noite (5 dez. 1951, p.5). A crônica "O Major" consiste, portanto, em uma reformulação dessa outra narrativa que a antecedeu em sete anos, dela diferindo principalmente 
pela inclusão de novas passagens e pela alteração do nome do protagonista que, de Major Alfredo Assumpção Bragança, em 1951, passa, em 1958, a Major Ponciano de Azeredo Furtado, antecipando, assim, nome e sobrenomes do protagonista do romance de 1964. Portanto, embora José Cândido tenha demorado a publicar O coronel e o lobisomem, o que se verifica por sua produção ficcional na imprensa é um longo processo de maturação de alguns elementos que depois comporiam esta que foi sua obra de maior sucesso.

$\mathrm{Na}$ verdade, a ideia de escrever um romance era gestada ainda em momento anterior ao período de publicação dessas crônicas. Esse lento projeto de criação, que só se concretizaria em 1964, deixou indícios de seu percurso em diferentes materiais. Já em 1950, quatorze anos antes do lançamento de $O$ coronel e o lobisomem, foi publicada na imprensa uma nota intitulada "A volta de José Cândido de Carvalho", em que se anunciava um novo romance do autor: "Consta que José Cândido de Carvalho possui, inédito, um romance, intitulado 'Porto de Angústia'. Assim sendo, é mais do que possível que em breve o jovem escritor fluminense o lance" (A Manhã, 20 ago. 1950, Suplemento Letras e Artes, p.6). No entanto, contrariando as expectativas, esse título nunca foi publicado pelo autor.

As características que especificamente $O$ coronel e o lobisomem viria a apresentar começam a se delinear sutilmente em publicações do autor ainda anteriores à mencionada crônica "O Major", texto que antecipa, em nível já bastante amadurecido, elementos desenvolvidos no romance. Assim, em 27 de outubro de 1953, José Cândido, em crônica intitulada "Conversa sem importância", já admitia possuir "um romance nos estaleiros": "O meu famoso amigo Lúcio Cardoso, relembrando velhas conversas de mesa de café, espalhou a nova de que tenho um romance nos estaleiros. Humildemente, como certas figuras da Bíblia, vos digo que sim. Aconteceu há muito tempo" (Carvalho, 1953, p.27). Já por essa contextualização que inicia a crônica, é possível perceber que o texto aproxima-se da construção de um espaço biográfico, por meio do qual se identifica a voz do "cronista-narrador" como uma figuração do autor empírico ou, ainda, como uma persona do autor. 
A partir desse preâmbulo, o cronista narra como os originais de um romance que produzira inspirado na paisagem de uma pacata cidade foram rejeitados pelo diretor de um jornal, sob a alegação de conterem períodos muito curtos e, com isso, aparentarem escrita de um "revolucionário" ou "anarquista". O cronista então relata como ele, revolucionário aspirante a escritor, e o diretor do jornal, retrógrado e conservador, começaram a trocar farpas nos jornais.

Nesse ponto é interessante observar que a caracterização do diretor do jornal denota um sujeito apegado ao passado, a um estilo de escrita em desuso, tossindo "seu catarrinho de 1830" e fungando “à maneira de 100 anos atrás" (Carvalho, 1953, p.27). Entre esses elementos que ressaltam seus modos antiquados, encontra-se um que será caro também à figura do Ponciano romanesco: a "farda de major da Guarda Nacional" - salvo a diferença hierárquica, pois o Ponciano do romance, em vez de major, foi alferes, capitão e, por fim, coronel, portanto, "Oficial Superior" da Guarda Nacional. Finalmente, no desfecho da narrativa, o cronista conta como, depois do desentendimento com o diretor do jornal, partiu da pequena cidade levando consigo o projeto de um novo romance:

Enfim, lá se foi o trem levando a revolução que eu era. E enquanto a maquinazinha comia os trilhos, pensei, sem mágoas e sem rancores, como seria gostoso arrumar todo aquele mundo em páginas de livros e pedir ao bom José Olímpio (sic) que lhe desse prestígio e vida. E foi assim, num pacato trenzinho de estrada deficitária a 20 quilômetros por hora, que nasceu o meu romance. O balzaquizinho de porão que sempre viveu em mim, pulou para fora. E agora, José? (Carvalho, 1953, p.27)

Como se pode observar, aparecem outros elementos, além da menção ao amigo e também escritor Lúcio Cardoso, que confirmam a instauração de um fundo biográfico na narrativa, agora evidenciado na referência ao editor José Olympio, a quem José Cândido mais tarde realmente procuraria para lançar $O$ coronel e o lobisomem, e na utilização do próprio nome "José" ao referir-se a si mesmo, 
parodiando o famoso poema de Carlos Drummond de Andrade. Logo, compreendida a presença da voz de José Cândido no texto, ainda que como uma persona, pode-se daí chegar a algumas hipóteses: como até a época da publicação dessa crônica não havia ele conquistado fama como ficcionista, utiliza a expressão "balzaquizinho de porão" para referir-se à propensão, que nele continuava a existir, ao romance. "Balzaquizinho", no diminutivo, indicia ainda certo menosprezo ou modéstia em relação a sua capacidade criadora, como que demonstrando consciência de suas próprias limitações enquanto romancista.

Importa esclarecer, nesta altura, que se sua estreia literária com Olha para o céu, Frederico!, em 1939, não lhe conferiu significativa notabilidade, muito menor foi a repercussão de uma narrativa de mais de 200 páginas que fez para crianças, em 1941, intitulada Pinóquio à procura de Branca de Neve. Assinada apenas como "Cândido de Carvalho", a narrativa fantasiosa e voltada ao público infantil foi ilustrada pelo desenhista Solon Botelho e composta pela editora Getúlio Costa, em pleno ápice da Segunda Guerra Mundial. ${ }^{9}$ A obra, todavia, parece ter sido renegada pelo próprio autor (Carvalho, 2004, p.113-4), uma vez que nunca foi reeditada, sendo hoje raríssimas as cópias conhecidas e as ocasiões em que a ela se faz menção. Com isso, José Cândido continuava, na década de 1950, quase que ignorado pela cena literária. Antes dele próprio se assumir como um "balzaquizinho de porão", essa já vinha sendo, de certo modo, a imagem dele construída pela imprensa, como demonstra uma nota intitulada "Romancista esquecido", publicada em A Noite, na coluna de Augusto Maia (1952, p.3), em

9 A propósito do lançamento do livro, Paulo Cabral publicou uma resenha intitulada "Um escritor para crianças", na qual afirmava: "Pinóquio à procura de Branca de Neve é um verdadeiro romance, obra de ficção que os garotos de todas as idades lerão com prazer. Mesmo aqueles que já vão descendo a curva da longa estrada, encontrarão nas páginas de Cândido de Carvalho muita coisa para se desintoxicarem do ambiente que se respira hoje, trágico e doloroso. $\mathrm{O}$ livro [...] demonstra que no mundo ainda há lugar para o riso..." (A Noite, 21 dez. 1941, p.4). 
que é mencionado como um escritor a quem a carreira de jornalista havia roubado da literatura:

Falava-se do jornalismo, responsável pelo corte de muitas carreiras literárias: - Querem um exemplo fluminense? [...] O Zé Cândido de Carvalho, diretor de "O Estado" e da Imprensa Estadual. Revelou-se como romancista, publicando o Olha para o céu, Frederico! e se meteu em jornal. Hoje, nem para o céu o rapaz olha mais: seu tempo é pouco para atender aos vários jornais onde trabalha...

O próprio José Cândido, em entrevista a $O$ Globo, ratificaria, anos mais tarde, essa imagem de "romancista esquecido" que dele se fez enquanto não publicava outro romance: "Meu primeiro livro (Olha para o céu, Frederico!) ficou na segunda edição até 1947. Durante vinte e cinco anos não tratei mais de literatura, deixei de gostar. Dediquei-me a ser diretor de jornais fluminenses. Era um autor desaparecido" (Carvalho, 1974, p.33). Por outro lado, a afirmação do autor de que deixara de tratar e de gostar de literatura por vinte e cinco anos parece contrastar com o que se pode observar nos jornais do período, ao noticiarem seus projetos literários. Nesse sentido, o que se pode realmente constatar é que, depois de estrear no romance em 1939 e publicar um livro infantil em 1941, José Cândido mantivera-se aproximadamente uma década afastado da ficção romanesca, mas, passado esse período, não demorou muito - os vinte e cinco anos que alega - a começar a planejar e a amadurecer a ideia de escrever um novo livro. Assim, à publicação dessas obras de 1939 e 1941, seguiram-se anos mais tarde, recapitulando cronologicamente: o anúncio frustrado de "Porto de Angústia", em 1950; a crônica "A guerra do Paraguai em pessoa”, em 1951, que seria reformulada, em 1958, como "O Major"; e a crônica "Conversa sem importância", de 1953, que, informando um romance em construção, já apresentava indícios dos elementos que seriam desenvolvidos na obra de 1964. Ainda na década de 1950, o projeto do "balzaquizinho de porão" de escrever uma nova obra continuava a alimentar a expectativa da imprensa de que o "romancista esquecido" ressurgisse: 


\section{Novo livro de José Cândido de Carvalho}

José Cândido de Carvalho, que estreou em 1939, com Olha para o céu, Frederico!, romance do drama do açúcar na baixada fluminense, prepara um novo livro, desta vez ainda um romance. É ainda a paisagem fluminense que inspira o Sr. José Cândido de Carvalho. O cenário do seu livro é precisamente aquele do fim de império e começo da República. (A Noite, 17 ago. 1954, Ilustrada, Carroussel Literário, p.36)

Como se pode notar, nesse anúncio assinado por Armando Pacheco, em 1954, José Cândido já pretendia escrever um livro cujo cenário fosse a "paisagem fluminense" do final do século XIX, tal como o seria O coronel e o lobisomem. Em 1954, portanto, se a figura de Ponciano e o título do livro não haviam ainda aparecido, a intenção, ao menos, de escrever um romance com as características daquela que seria sua obra mais conhecida já era evidente. A obra, talvez, até se chamasse Ventania em agosto, como comprova uma interessante correspondência de 1957, encontrada nos arquivos digitais da ABL (Carvalho, 1957), por meio da qual José Cândido dá notícias de um novo livro a seu amigo, jornalista e crítico literário, Nelson Werneck Sodré:

Prezado amigo Nelson, não sei se coronel, não sei se general:

Junto mando um exemplar do velho e desmoralizado "Frederico". Não me esqueço de que você foi o melhor padrinho literário que ele teve nos remotos dias de 1939. Já tenho outro romance preparado que o José Olimpio vai publicar: "Ventania em agosto". Tenho a honra de dedicar o catatau a você. É a minha homenagem a um homem de ideas (sic) e de raro talento.

Abraços do seu admirador constante,

José Cândido de Carvalho.

Rio, 20/11/1957.

O bilhete, escrito em papel timbrado da editora O Cruzeiro, onde José Cândido trabalhava na época, contém alguns detalhes 
curiosos pelas coincidências em relação ao processo de construção de O coronel e o lobisomem. Por exemplo, logo na saudação, o autor utiliza como aposto ao vocativo as frases "não sei se coronel, não sei se general". Além de ser referência ao compêndio de contradições que definiu a vida de Sodré, ${ }^{10}$ a oscilação de titulações militares se daria, posterior e coincidentemente, nas patentes de Ponciano, em suas diferentes figurações, na crônica (major) e no romance (coronel). Além disso, o título prometido, Ventania em agosto, revela a atmosfera do romance dado como pronto, que certamente remete, considerando-se o enredo do livro de 1964, a um período de tragédias, conforme ideia também sintetizada nos ditos populares "agosto, mês do desgosto" ou "agosto, mês do cachorro louco", podendo indicar inclusive a presença do lobisomem na narrativa. Vale lembrar que a promessa de dedicar o "catatau" ao amigo foi cumprida, no entanto, somente na terceira edição de $O$ coronel e o lobisomem, pois, por alguma razão, a primeira fora dedicada apenas a seu pai e a seus amigos Herberto Sales e Aurélio Buarque de Holanda. Outro detalhe é que o autor reafirma no bilhete o que dissera na crônica "Conversa sem importância", de 1953, quanto à intenção de que o livro fosse publicado pela editora de José Olympio.

Meses após essa correspondência datada de novembro de 1957, José Cândido publicou, então, em agosto de 1958, a mencionada crônica "O Major", apresentando seu protagonista Ponciano de Azeredo Furtado, como ficou visto. Na sequência, em agosto de 1960, exatamente dois anos depois da crônica, sairia uma nota, na coluna "Cartaz I" do Diário Carioca, que anunciava: "O coronel $e$ o lobisomem é o novo romance de José Cândido de Carvalho, autor de Olha para o céu, Frederico!. O livro, que conta a história de um fazendeiro (arruinado) de Campos, está pronto para ser entregue ao

10 No momento em que José Cândido escreve, Nelson Werneck Sodré (19111999) já havia alcançado, em sua carreira junto ao Exército, o posto de general de brigada, conciliando essa função a sua formação como sociólogo, historiador de orientação marxista e crítico literário. Em agosto de 1961, quatro anos após essa correspondência, o historiador militar foi promovido, por antiguidade, a coronel, último posto da carreira no Exército (IPEA, 2011). 
editor" (Diário Carioca, 14-15 ago. 1960, Suplemento dominical, Letras e Artes, p.3). Apesar de o editor não ter sido nomeado pela notícia, pode-se inferir que fosse alguma das editoras que José Cândido procurara antes de decidir publicar o romance pelas edições de O Cruzeiro. Já para essa editora, entregaria os originais apenas em julho de 1963: "O jornalista José Cândido de Carvalho, que publicou há anos o romance Olha para o céu, Frederico!, vem de entregar (sic) à Editora Cruzeiro um novo livro, romance também: O coronel e o lobisomem" (Campos, 1963, p.3). O desejo do autor de ver sua obra editada seria, portanto, concretizado somente em maio de 1964, mês de impressão do romance pela editora $\mathrm{O}$ Cruzeiro, que o distribuiu às livrarias no começo de julho. É importante frisar que a descoberta dessas datas elimina a legitimidade de leituras que busquem compreender o romance como uma crítica ou sátira direta ao período ditatorial instaurado no Brasil no ano de publicação do livro.

Ao revelar as etapas de seu processo de criação, esse percurso demonstra que o autor não permaneceu durante vinte e cinco anos completamente distante do romance, uma vez que vinha, há muito tempo, amadurecendo os elementos que mais tarde empregaria em sua célebre narrativa. Assim, compreende-se também que muito da autoimagem de escritor "preguiçoso" (Carvalho, 2004, p.109), criada por ele para justificar a pouca produção romanesca, deve-se, antes, a uma busca de aperfeiçoamento e esmero do que, propriamente, ao ócio alegado. Também por isso, não só $O$ coronel $e o$ lobisomem demorou a ser escrito; processo semelhante seguiu seu romance $O$ Rei Baltazar, com a grande diferença de que este sequer chegou a ser lançado em vida do autor, que o prometia como último livro de sua carreira. Com o processo de elaboração noticiado desde março de 1974 (Faria Netto, 1974, p.3), o romance teve seu lançamento anunciado ainda para aquele ano (Jornal do Brasil, 1 set. 1974, Caderno RJ, p.4), porém, José Cândido faleceu em agosto de 1989, quinze anos depois do anúncio e exatamente vinte e cinco anos após a publicação de $O$ coronel..., deixando-o inacabado.

Em uma de suas últimas entrevistas, José Cândido explicava, com o humor que lhe era peculiar, a demora em lançar o livro por 
tão longo tempo prometido: "Eu só escrevo quando estou muito inspirado. Quer dizer, inspiração minha é muito rara, porque eu não sou como o Jorge Amado, que tem inspiração 24 horas por dia. Eu só tenho inspiração de três em três meses" (Carvalho, 2004, p.109). E, entre sério e trocista, afirmava que escrevia apenas por necessidade: "É a tragédia de não ser rico: a gente tem que escrever e ler" (Carvalho, 1971, p.2). A dificuldade de escrever, segundo ele "um carregar pedras sem fim" (Carvalho, 1984, p.11), era outra razão dada para explicar sua demora em publicar. Apesar de não gostar de conceder entrevistas, as poucas que deixou são também elucidativas de seu lento e árduo processo de criação. Nelas relatou sua luta com as palavras, principalmente com os adjetivos, com as personagens que pareciam adquirir vida própria e com a dificuldade de encontrar a linguagem adequada ao perfil de seus narradores. Suas declarações sobre a relação conflituosa que mantinha com a escrita soam até irônicas, não por parecerem inverdades, mas, pelo contraste que estabelecem com sua condição de jornalista, romancista consagrado, contista, cronista e membro da Academia Brasileira de Letras, ocupações todas centradas no uso da palavra. Nesse sentido, afirmou em depoimento concedido a Maria Aparecida Bacega:

Escrever, para mim, é uma danação. Eu não gosto de escrever. [...] A pessoa normal, um escritor como eu - um pequeno escritor - tem que se contentar com isso mesmo: escrever com dificuldade. Eu escrevo, reescrevo. Quando escrevo uma página, fico muito contente.

$[\ldots]$

Travo uma luta terrível com o adjetivo. Não sou uma pessoa fácil de escrever. Escrevo uma cópia, duas, três. Mesmo nos meus artigos de jornal - escrevo para um jornal de Niterói chamado $O$ Fluminense - faço duas, três cópias para chegar à versão definitiva. Não que eu seja pessoa perfeccionista, não. É do meu temperamento: mudo muito as coisas. (Carvalho, 1983, p.6) 
Se a exigência era tamanha mesmo em relação às publicações periódicas, sujeitas à efemeridade pelo próprio suporte, quanto mais em relação à escrita destinada à publicação em livros, que implicam certa condição de permanência. Sobre esse esforço, admitiu: "Neles [nos livros] coloquei o que tenho de melhor em escrever e romancear. Sou de raro trabalhar. Só de muitos anos em muitos anos é que desovo obra" (Carvalho, 1984, p.11). Ademais, a preocupação do autor não se limitava ao apuro da linguagem e do estilo. Os detalhes do conteúdo das obras foram também produto de intensa dedicação e pesquisa. Sobre esse trabalho envolvido na composição de seus livros, a biógrafa Cláudia Nina (2011, p.52) comenta que o autor "[...] fazia pesquisas tão minuciosas que, segundo sua filha Laura, havia listas de dezenas de tipos de capim que costumava investigar. E não só capim. Há listas de pássaros, patos, cobras, vegetação de lagos, árvores, peixes e até marrecas e ruas de Campos". Com isso, percebe-se a dimensão de seu empenho para com a escrita ficcional.

Ainda nesse sentido, entre os gêneros ficcionais que cultivou, elegeu o romance como o de maior complexidade:

Romance é assunto dificultoso para um papa-goiaba do Largo da Batalha de Niterói como eu. É que escrevo complicado, meio sobre o barroco. Limpo a escrita três ou quatro vezes. Só depois, com muito suor e lágrimas, é que a coisa vai ficando menos samburá de caranguejo, clareando. (Carvalho, 1984, p.11)

A escolha desse gênero proteico e multiforme como o de maior dificuldade para composição pode ser compreendida também em função de uma autoexigência bastante peculiar - uma de suas "limitações", como ele dizia - em relação a sua produção romanesca: “eu não gosto de me imitar”, declarava (Carvalho, 2004, p.100). Imitar-se corresponderia, segundo ele, a repetir o tipo de linguagem de um romance para o outro. Como criador de personagens marcantes, seus três romances (inclusive o que deixou inédito) são narrados em primeira pessoa: Olha para o céu, Frederico! é narrado 
por Eduardo, sobrinho de Frederico, em uma narração homodiegética; O coronel e o lobisomem aparece na voz do próprio coronel Ponciano, narrador autodiegético, e $O$ Rei Baltazar é contado por Diogo Maldonado de Sá, também narrador-protagonista. ${ }^{11}$ Mas, para José Cândido, não bastava criar personagens diferentes, era preciso desenvolver também uma nova linguagem para cada uma delas. $\mathrm{O}$ autor defendia que a linguagem do seu primeiro romance para o segundo era diferente e que assim deveria ser com o novo livro. E explicava:

[...] para eu fazer a linguagem de Frederico, eu faria dez livros. Como, hoje, eu faria dez livros na mesma linguagem de O coronel? [...] Veja bem. O nosso Guimarães Rosa fez um livro, mas ele chegou, a linguagem dele era a mesma em todo lugar. E eu, então, não gosto. Eu gosto de fazer outra linguagem. (Carvalho, 2004, p.100)

Como a personagem do último romance seria um "tabelião juramentado", José Cândido buscou criar uma linguagem que fosse condizente à visão de mundo desse profissional, uma "linguagem de tabelião": "Você imagina um tabelião na cama, amando, falando em linguagem de tabelião? [...] amando, como se fizesse um ofício" (Carvalho, 2004, p.73). Para empreender essa difícil missão, segundo Cláudia Nina (2011, p.133), o autor pesquisou intensamente a linguagem utilizada por escrivães, "construindo toda a narrativa com um linguajar que beira o estilo quinhentista".

Com base no conhecimento da linguagem dos romances de 1939 e de 1964, é possível afirmar que, embora haja um visível e maior investimento nos recursos linguísticos deste último, deve-se admitir, naquele, a existência de uma temática e de certos "lampejos"

11 "O livro é a história de um tabelião que enriquece e, depois, empobrece. Mas o que é interessante no livro é que ele é uma pessoa 'encantada', ali no livro. Ele fala por três pessoas. Porque nós, você, eu e ele, todos nós temos gente por dentro” (Carvalho, 2004, p.109). Cláudia Nina (2011, p.133) afirma que dessa técnica resulta "um romance complicado, de uma polifonia complexa e perturbadora no melhor sentido". 
estilísticos anunciadores de sua obra consagrada. Do mesmo modo, com a leitura dos fragmentos do romance ainda inédito, fica a impressão de que, a despeito do esforço do autor para "não se repetir", há uma essência em seu estilo que lhe é própria e da qual, positivamente, não consegue se esquivar. A busca por novas linguagens para seus narradores, muito justificável em função da harmonia entre quem diz e o modo como diz, não consegue apagar a própria linguagem autoral que há por detrás delas, e, com isso, beneficamente particulariza sua escrita, tornando-a peculiar e constante, sem, no entanto, ser a mesma.

Com toda essa preocupação e exigência, fica mais fácil compreender o retardo do lançamento de seus romances. Sobre o árduo processo de composição de $O$ coronel e o lobisomem, em específico, José Cândido, em declaração hiperbólica e bem-humorada encontrada por Cláudia Nina nos arquivos da ABL, revela:

Esguichei suor de chafariz para escrever as 250 páginas de $O$ coronel e o lobisomem. Pinheirais da Finlândia e do Paraná foram convertidos em papel que escrevi e inutilizei em meus largos anos de escriturizações, virgulações e craseações. Uma guerra, uma batalha. (Carvalho apud Nina, 2011, p.51)

Em síntese, José Cândido considerava ficção assunto sério e "dificultoso". O autor parecia seguir o legado de Machado de Assis, que asseverou aos escritores: "A precipitação não lhe afiança [à mocidade] muita vida aos escritos. Há um prurido de escrever muito e depressa; tira-se disso glória. [...] Faça muito embora um homem a volta ao mundo em 80 dias; para uma obra-prima do espírito são precisos alguns mais" (Machado de Assis, 1979, p.809). Assim, perfeccionista, o escritor não se permitia, apesar das inúmeras atividades que desenvolveu, tratar com descuido ou incúria suas produções ficcionais. Daí declarar:

Quanto à ficção, é mato brabo no qual rarissimamente circulo, temente que sou de mordida de cobra e dente de lobisomem. Vejam 
que não exagero. Publiquei o primeiro livro em 1939 e o segundo precisamente vinte e cinco anos depois. Entre Olha para o Céu, Frederico! e O Coronel e o Lobisomem o mundo mudou de roupa e de penteado. (Carvalho, 2007, p.12)

Com efeito, o romance $O$ coronel e o lobisomem demorou a ganhar forma e vir a público, seja em função da sua intensa atividade junto a outros setores ou do seu incansável e exigente trabalho de criação e depuração da escrita. Há, de fato, um considerável intervalo - ou "um balaio de tempo", como o próprio autor afirmou - entre seu romance de estreia e aquele que o consagrou - como o haveria também em relação ao que permanece inédito. Por isso, dizia-se um "escritor geracional", alguém que escreve "de temporada em temporada" $(O$ Globo, 27 jan. 1985, p.10). Para ele, O coronel e o lobisomem surgiu em momento tão distante e diferente da época de seu primeiro romance, que "o mundo havia mudado de roupa e penteado", e completava: "Basta dizer que nos dias de Frederico o mundo andava de aeroplano e agora no tempo do Coronel, o planeta viaja de jato. Nos dias do meu primeiro romance a lua ainda era dos namorados. Hoje é dos astronautas [...]" (Carvalho, 1984, p.11-2).

Dessa distância, a princípio temporal, emergiram as inquietações propulsoras deste livro: em que medida estaria o romance $O$ coronel e o lobisomem, de 1964, afastado da obra Olha para o céu, Frederico!, de 1939? Seria possível afirmar que o romance escrito vinte e cinco anos depois da estreia do autor na década de 1930 responde não apenas a um novo tempo histórico, mas a uma nova fase da literatura brasileira? A qual tendência literária o romance de 1964 estaria associado? Como a crítica o situou na historiografia literária? Que leitura pode-se fazer hoje do romance, tendo-se em vista o momento em que surgiu? Em outras palavras, como a geração em que o romance se inscreve poderia iluminá-lo? E, em sentido inverso - e talvez mais importante -, que leitura desse romance pode ampliar ou mesmo ressignificar a compreensão de uma fase da literatura brasileira a qual, presumivelmente, se relaciona? Conhecidas as instâncias de produção de $O$ coronel e o lobisomem e a posição da obra 
no conjunto ficcional de seu autor, é momento de propor respostas a essas indagações.

\section{O mundo mudou de roupa e penteado... e o romance regionalista também?}

A escritora Rachel de Queiroz (1983, p.ix), em 1970, por ocasião da reedição de $O$ coronel e o lobisomem, então pela José Olympio, fez a seguinte declaração:

Com $O$ coronel e o lobisomem, José Cândido deu vida nova ao regionalismo brasileiro. Até então parecia que alguém querendo apresentar o homem do interior, sua vida, seus amores, suas lendas e problemas, teria que inventar fórmula diferente, porque o velho romance regional, o velho conto, supostamente não tinham mais nada para dar... E vem agora José Cândido de Carvalho provar que, havendo crânio, talento, boa boca, nenhum assunto está esgotado ou morto.

Essa abordagem proposta pela autora, apesar de, num primeiro momento, poder parecer simplista, demanda, na realidade, uma série de conhecimentos para que seja compreendida e averiguada em suas implicações. Ajuizar que o romance $O$ coronel e o lobisomem corresponde a um novo regionalismo literário é pressupor a existência de um regionalismo anterior, do qual a obra, portanto, se diferiria. Subjaz, ainda, a essa afirmação um conceito de "regionalismo". Afinal, o que exatamente está se considerando regionalismo no âmbito da literatura brasileira? Nessa perspectiva, o que diferenciaria o "velho romance regional" do novo? Quais características do romance de José Cândido estão sendo consideradas para vinculá-lo a esse novo regionalismo? E, além disso, quais características estariam preservadas na obra para que, mesmo de modo renovado, continue a se identificar com o regionalismo?

Como a autora menciona apenas $O$ coronel e o lobisomem e não o outro romance do autor, Olha para o céu, Frederico!, na época em 
sua segunda edição, parece acertado concluir que somente com a obra de 1964 José Cândido teria conseguido conferir "vida nova" ao regionalismo brasileiro. Desse modo, pode-se deduzir que haveria entre os romances uma distância não apenas temporal, em função do intervalo entre suas publicações, mas também composicional e estilística, que corresponderia a momentos diferentes da produção do autor e, em um nível mais amplo, a estágios distintos de uma linhagem da produção romanesca nacional.

Na trilha dessas suposições, antes de perscrutar o conceito demasiado abrangente e complexo de regionalismo por definições teóricas e generalizantes, convém apresentar algumas considerações sobre esses romances do autor, especulações que serviram como pressuposto à presente análise. Para tanto, o romance Olha para o céu, Frederico! será lido tendo-se em perspectiva o romance $O$ coronel e o lobisomem, de modo a salientar os pontos de contato e distanciamento entre essas obras e suas possíveis relações com diferentes momentos do chamado regionalismo literário brasileiro. Essa etapa faz-se necessária, portanto, por desenvolver um raciocínio que, de uma percepção inicial apenas entrevista, passou a conduzir e justificar o caminho de análise proposto, nos capítulos 2 e 3, ao romance foco deste estudo. Dessa maneira, acredita-se que, para compreender o trajeto percorrido por José Cândido de Carvalho até se tornar autor de O coronel e o lobisomem, é fundamental observar, com mais vagar, seu romance de estreia, Olha para o céu, Frederico!.

\section{Frederico pela crítica: a estreia de José Cândido de Carvalho}

Escrito em 1936, mas lançado apenas em meados de 1939, o romance Olha para o céu, Frederico! marcou a estreia literária do então jovem jornalista José Cândido de Carvalho. Ao curioso título, seguia-se, na capa, um subtítulo que anunciava o gênero e a temática da obra: "Romance do açúcar na Baixada Fluminense". Editado pela Vecchi, na coleção Novos Autores Brasileiros, o romance, se na 
época não obteve grande visibilidade, conseguira ao menos tornar seu autor conhecido como romancista no meio literário. ${ }^{12}$

O romance de estreia de José Cândido foi, de modo geral, bem recebido pela crítica, ${ }^{13}$ mas sem muita surpresa, já que muitos resenhistas destacavam sua semelhança em relação à produção já consagrada de José Lins do Rego, de quem o jovem escritor era admirador confesso. A propósito dessa relação, o próprio autor, posteriormente, admitiria: "É um livro audacioso, porque entrei na seara de um grande escritor, que é o José Lins do Rego. Li muito José Lins do Rego, maravilhoso escritor [...]" (Carvalho, 2004, p.99). Entre os críticos que apontaram essa vinculação, Eliezer Burlá, comentando as "estreias promissoras" de 1939 no artigo "Três Novos", afirmou:

José Cândido estreia logo com uma desvantagem: usar a cana-de-açúcar como tema de romance. Esqueceu-se ele que tudo o que se referia a engenhos, mestres de tacha, usinas e banguês pertenciam, em copyright, a Zé Lins do Rego. Mas, apesar disso, a comparação inevitável não o atemorizou, e eis que ele nos apresenta um volume modesto e espontâneo: Olha para o céu, Frederico!

12 Em 14 de dezembro de 1939, para comemorar o centenário de Machado de Assis, o jornal literário Dom Casmurro preparou uma confraternização em homenagem aos ficcionistas do ano. Assim, o nome de José Cândido figurou entre outros homenageados, como José Lins do Rego, Rachel de Queiroz, Érico Veríssimo, Cornélio Pena, Marques Rebelo, Jorge de Lima e outros importantes escritores (Dom Casmurro, 9 dez. 1939, p.12; 16 dez. 1939, p.5).

13 Pode-se verificar essa acolhida nas seguintes fontes, entre resenhas, notas e comentários: "Livros Novos" (Jornal do Brasil, 12 jul. 1939); "Novos autores brasileiros", por Omer Mont'Alegre (Dom Casmurro, 16 set. 1939, p.8); "Três novos", por Eliezer Burlá (Dom Casmurro, 6 jan. 1940, Crítica, p.6); "Livros" (A Noite, 28 mar. 1940, p.4); "A produção literária de 1939”, por Emo Duarte, (Dom Casmurro, 13 abr. 1940, p.7); "Viagem em torno de Tônio Borja”, por Lêdo Ivo (Dom Casmurro, 7 dez. 1940, Crítica, p.6); "Olha para o céu, Frederico!”, por Roberto Lyra (A Noite, 11 fev. 1942). Outros pareceres também favoráveis à obra foram emitidos por escritores, entre ficcionistas e críticos, como Mário de Andrade, Jorge Amado, Alceu Amoroso Lima e Nelson Werneck Sodré, cujas apreciações, publicadas primeiramente em jornais, encontram-se reproduzidas na contracapa da primeira edição de O coronel e o lobisomem (Carvalho, 1964). 
[... Acontece, porém, que os ambientes da Baixada [Fluminense] são semelhantes aos do Vale do Paraíba, isto é, iguais àqueles que em cinco volumes Zé Lins nos descreveria. Seria natural que o romance de Cândido de Carvalho sofresse a influência do autor de Doidinho, seria mais do que natural que lhe imitasse a linguagem, que descrevesse os mesmos personagens. Foi natural ainda que os críticos apressados vissem nele um discípulo sem méritos, um escritor de poucos recursos. Mas para quem o leu sem prevenções foi reservada uma surpresa: José Cândido era um escritor nato, um escritor ainda em início, sim, mas uma bela afirmação literária. (Burlá, 1940, p.6)

Embora a maioria dos críticos da época tenha compartilhado dessa visão positiva e acolhedora a respeito da obra, anos mais tarde, quando do lançamento de $O$ coronel e o lobisomem, Wilson Martins (1964, p.2) publicaria um artigo, intitulado "Uma obra-prima", tão elogioso ao romance de 1964 quanto ácido em relação ao de 1939. O crítico, na mesma medida em que entusiasticamente exaltava as qualidades de um, rebaixava a importância e o mérito do outro. Assim, enquanto $O$ coronel e o lobisomem era "um extraordinário romance brasileiro e uma obra de arte sem falhas", que conferia "novas dimensões ao romance brasileiro", Olha para o céu, Frederico! sofria "de todas as limitações características do exército de epígonos que florescia à margem do 'ciclo da cana-de-açúcar' e do 'romance social”' (p.2). Acusou, ainda, o romance de 1939 de ser medíocre e de ter contado com a benevolência da crítica da época, que se contentava com escritores que "obedeciam docilmente aos padrões aceitos", chegando a afirmar:

Em larga medida, foi um erro literário consentir na segunda edição de Olha para o céu, Frederico!, e a prova está na nenhuma repercussão desse lobisomem literário no mundo intelectual dos nossos dias [...]; em 1939, o autor era talvez uma "promessa", como se diz, e, mais do que uma promessa, era um escritor excessivamente influenciado pela glória dos seus maiores, pelas modas transitórias, 
pelos cacoetes mundanos da literatura. (O Estado de S. Paulo, 11 jul. 1964, Suplemento Literário, p.2)

Curioso é que, apesar da mordacidade da crítica ao primeiro romance do autor, tamanho é o elogio a $O$ coronel e o lobisomem, que esse artigo seria depois publicado na reedição da obra pela José Olympio, em 1970. Como se viu, foi com essa edição que o romance ganhou, de fato, repercussão. Logo, certamente em função desse texto pouco convidativo à leitura do romance de 1939, o livro de estreia do autor permaneceu esquecido pela crítica, que se voltou, quase que exclusivamente, à "obra-prima” de 1964.

Buscando, talvez, desvincular a apresentação de Olha para o céu, Frederico! da temática da cana-de-açúcar - muito condenada pela crítica, mas fundamental ao enredo -, o subtítulo do lançamento, "Romance do açúcar na Baixada Fluminense", foi alterado nas edições seguintes, passando a "Romance acontecido em Campos dos Goitacases" (foco apenas no espaço), "Romance acontecido em Campos dos Goitacases nos dias do gramofone" (foco no espaço e tempo) ou, ainda, sendo excluído de todo. Isto, no entanto, não seria suficiente para que a obra deixasse de ser lida por esse viés, de modo que a aproximação com a prosa de José Lins faz-se, ainda hoje, importante quando o intuito é situar o romance no âmbito da literatura brasileira.

Nesse sentido, Luís Bueno, um dos poucos estudiosos contemporâneos que se ocupou do primeiro romance de José Cândido, confirma, em seu livro Uma história do romance de 30, que Olha para o céu, Frederico! apresenta-se como uma verdadeira súmula do "regionalismo à José Lins do Rego" (Bueno, 2006, p.447) e, a partir da comparação entre os autores, desenvolve sua leitura da obra. Entretanto, além das semelhanças, o pesquisador reconhece também os diferenciais da narrativa, que lhe conferem um lugar especial no interior do romance de 1930. Esse mérito, segundo ele, deve-se, sobretudo, à criação de personagens que fogem aos modelos convencionais da prosa do período, como o senhor de engenho Frederico, aparentemente ingênuo, mas sagaz em relação aos negócios, 
e Dona Lúcia, sua esposa adúltera, nada romantizada ou recatada. $\mathrm{O}$ crítico elogia, ainda, o motivo da obra - um narrador que tenta, sem sucesso, aviltar a imagem de seu tio -, mas considera que o romance não atinge a intensidade que poderia ter (p.453). Do balanço entre os acertos e as fragilidades que identifica no romance, Bueno (p.456) conclui: "De uma forma ou de outra há aqui um empenho em produzir uma obra que dialogue com a literatura de seu tempo sem deixar de buscar um caminho próprio. [...] obra que reafirma e procura renovar uma das correntes mais prestigiosas do romance de 30".

Como José Cândido mesmo resumiria, a verdade sobre a recepção de seu romance Olha para o céu, Frederico! é que "uns elogiaram, outros malharam” (Carvalho, 2007, p.12). Entre os primeiros, está o escritor Carlos Heitor Cony, que declarou recentemente, em uma conferência proferida na Academia Brasileira de Letras, preferir, entre os livros de José Cândido, o romance de 1939 ao de 1964, reconhecendo os valores deste, mas afirmando ser aquele "um grandessíssimo romance" (Cony, 2000).

Sem ignorar tais apreciações da crítica sobre o romance, é preciso, no entanto, lê-lo esquivando-se de certa visão estereotipada, uma vez que se queira compreendê-lo em sua posição e funcionalidade no projeto estético do autor. Como o foco da maioria das leituras da obra consiste em evidenciar sua inegável relação com a produção de José Lins, parece justificável propor uma abordagem que, sem negar esta, aponte outras intertextualidades quando preciso, mas centre-se principalmente na unidade do texto, mantendo em perspectiva seu romance de 1964. Sendo quase consensual que O coronel e o lobisomem é a obra-prima do autor, não se pode, todavia, negar a existência e a importância que teve seu primeiro romance como etapa necessária de experimentação e aprimoramento do desenvolvimento de sua prosa ficcional. 


\section{De Frederico a Ponciano: permanência e ruptura}

O romance Olha para o céu, Frederico! estrutura-se em duas partes: "Uma espécie de prefácio" e "O romance propriamente dito", sendo esta última constituída por 22 capítulos curtos e episódicos, composição semelhante à do livro $O$ coronel e o lobisomem. A narrativa também é ambientada em áreas rurais do norte fluminense. Essa espacialidade se comprova pela referência a localidades do estado do Rio de Janeiro, como Campos dos Goytacazes, Mussurepê, Santo Amaro e Quissamã. A região de Campos dos Goytacazes assume, inclusive, importância capital nas obras, indicada já por seus subtítulos: "Romance do açúcar no norte fluminense" (Carvalho, 1974) e "Deixados do Oficial Superior da Guarda Nacional, Ponciano de Azeredo Furtado, natural da praça de São Salvador de Campos dos Goitacases" (Carvalho, 1983). Assim, nesses romances, o espaço não aparece apenas como plano de fundo das narrativas, mostrando-se, antes, de extrema relevância para a configuração dos conflitos experienciados pelos narradores-personagens ao transitarem entre os contrastes do campo e da cidade, em um momento de profundas transformações econômicas e sociais.

Desse modo, há também, nas narrativas, elementos que permitem a ancoragem temporal dos enredos num plano histórico. No caso do primeiro romance, em específico, isso ocorre com precisão quando, a certa altura, o velho senhor de engenho Frederico afirma viver na região de Campos desde 1849 (Carvalho, 1974, p.68). ${ }^{14}$

14 É importante salientar que essa data aparece como 1889 nas três primeiras edições do livro, e não como 1849, como consta da quarta edição, revisada pelo autor. Descarta-se a possibilidade de ter havido algum problema tipográfico, pois a menção ao ano aparece mais de uma vez na narrativa, sem que destoe no interior de uma mesma edição. A primeira edição foi lançada pela editora Vecchi, em 1939, a segunda pela O Cruzeiro, em 1957, e a terceira, pela José Olympio em parceria com as editoras Três e Civilização Brasileira, em 1974. Essa alteração - além de outras que uma análise comparativa poderia identificar - foi realizada para a quarta edição da obra, que também sairia em 1974, publicada apenas pela José Olympio, na coleção Sagarana. Nessa edição, entre os paratextos do livro, há uma apresentação cujo título é "Um velho amor de 
Somando-se a isso um comentário de um de seus vizinhos - que afirma morar há mais de cinquenta anos no local e nunca ter visto Frederico se afastar de sua propriedade (p.82) -, é possível deduzir o período aproximado em que transcorre a ação do romance: entre meados do século XIX e início do século XX. Outros detalhes da narrativa confirmam, ainda, esse intervalo de tempo, como a menção ao extinto Teatro São Salvador (p.56), fundado em 1845 e demolido em 1919 (Sendra; Rangel, 2011), bem como a referência utilizada em um dos subtítulos da obra (Carvalho, 1974) ao gramofone, aparelho que surge no Brasil nas primeiras décadas do século XX (Palma, 2011). Assim, o período de tempo representado na obra encontra correspondência com episódios históricos do país, em um momento marcado, tanto no registro historiográfico quanto na criação ficcional carvalhiana, pela modernização dos engenhos da baixada fluminense. ${ }^{15}$

1939”, assinada pelo autor em abril de 1974. Nela, José Cândido esclarece que a obra "Retorna com alguns cortes, meia dúzia de retoques e uma escovadela no lombo" (Carvalho, 1974, p.xiii). Assim, é provável que a alteração do ano de 1889 para 1849 se deva a uma busca de maior compatibilidade entre os fatos da narrativa e os episódios da história do Brasil, já que seria anacrônico situar a vida de Frederico, senhor de engenho representante de um sistema colonial ainda sólido, entre 1889 e 1939.

15 Do ponto de vista historiográfico, em estudo sobre a economia açucareira no norte fluminense, Paulo Paranhos (2006, p.4) explica que já no final do século XVII, com o declínio da produção no Nordeste brasileiro, começa a florescer a lavoura de cana-de-açúcar em Campos dos Goytacazes. No entanto, segundo o autor (p.4), seria no século XIX que "a produção açucareira campista atingiria o auge com a introdução de novas técnicas no fabrico do açúcar, além da entrada vultosa de capitais para o aprimoramento dos primitivos engenhos que se transformavam em engenhos centrais e em usinas. [...] é o momento do surgimento dos 'barões do açúcar' em todo o norte fluminense, ensejando a dominação política, econômica e social por parte dessa elite açucareira, que começa a se instalar em suntuosas mansões". Assim, a partir de 1850, período inicial da ação narrada no romance, o desenvolvimento de Campos estaria sustentado pela agroindústria do açúcar, seguida da aguardente e do café (p.5). Referência nacional na produção de açúcar, Campos teve ainda a instalação da primeira usina do Brasil (p.7), "a Usina do Limão, em Campos, entrando em funcionamento em julho de 1879”. Nas narrativas carvalhianas, a importância da temática açucareira da região campista anuncia-se já pelo primeiro subtítulo do 
Na primeira parte da obra, em "Uma espécie de prefácio", o romance se inicia com o narrador-personagem Eduardo de Sá Meneses, sobrinho de Frederico Meneses, explicando as circunstâncias que o motivaram a contar a história apresentada na parte seguinte. Nessa "espécie de prefácio", o narrador encontra-se em sua fase adulta e, portanto, em um momento de narração ulterior ${ }^{16}$ ao dos fatos que, na sequência, irá relatar. Assim, a outra parte do livro, "O romance propriamente dito", configura-se como uma narrativa em flashback, analepse por meio da qual o narrador-personagem rememora episódios de sua vida para tentar resgatar a história de seu tio. A técnica de se iniciar o romance com um discurso metalinguístico, procedimento recorrente em narrativas de cunho memorialístico, é também utilizada nas páginas iniciais do romance São Bernardo (1934), de Graciliano Ramos (1991b, p.7-11), quando o narrador Paulo Honório expõe as circunstâncias em que produziu seu relato. No romance de José Cândido, de maneira semelhante, o narrador, ao fazê-lo, não situa a princípio claramente seu leitor, pois a narração começa subitamente, de modo que tanto sua imagem quanto a das demais personagens vão se definindo aos poucos durante o enredo. Eis o início da narrativa:

Um dia apareceu na primeira página de $O$ Estado um trabalho de um tal de Melo Pimenta falando do meu tio Frederico de Sá Meneses. Botava o velho nas nuvens, num altar de glórias. Não gostei desses elogios rasgados a um parente que não era um Meneses legítimo. Pisei nas tamancas. Respondi em artigo bem calibrado. Fiz considerações sobre o nascimento de Frederico. Esclareci o assunto. Que ficasse sabendo o ilustre articulista que minha casa de dois andares tinha, em suas recordações, muitos outros tipos de

livro de 1939, "Romance do açúcar na Baixada Fluminense", e pela dedicatória da obra de 1964, "[...] à memória de meu pai, o vendedor de açúcar, Bonifácio de Carvalho, com ternura” (1983, p.1).

16 Entende-se por narração ulterior o ato narrativo que se situa numa posição de inequívoca posteridade em relação à história. Esta é dada como terminada e resolvida quanto às ações que a integram (Reis; Lopes, 2000, p.256). 
nobreza, barões de sangue limpo, um Pedra Lisa que deixou fama, que foi íntimo de Dom Pedro. Arrotei grandeza por tudo que foi vírgula. Falei até em cartas que o Imperador escreveu a meu bisavô. (Carvalho, 1974, p.5)

Por esse introito, o narrador apresenta a desavença que travou nos jornais com Melo Pimenta, autor do artigo elogioso à figura de seu tio Frederico, então, falecido. Eduardo sentira-se ofendido com os elogios dirigidos a seu tio, pois defendia que ele não tinha sido um "Meneses legítimo", juízo que, se saberá mais tarde, deve-se ao fato de Frederico ter sido mulato, de ter possuído "nas veias algumas gotas de sangue escuro" (p.6). Para Eduardo, sua família deveria ser representada em sua nobreza por seus antepassados barões, "de sangue limpo", como seu bisavô Pedra Lisa, que fora amigo de Dom Pedro II. Nessa convicção de Eduardo reside, claramente, um preconceito racial elitista, decorrente de uma ideologia de branqueamento que se formara com as teorias eugênicas desenvolvidas no final do século XIX na Europa, e que mesmo a intelectualidade brasileira adotaria nas primeiras décadas do século XX.${ }^{17} \mathrm{O}$ autor, ao representar esse conflito, também denuncia, coerentemente à tendência do romance de 1930, um embate em que condição social e racial se confundem num mesmo preconceito elitista.

Eduardo publica essas opiniões no jornal Monitor Campista, num artigo em resposta ao texto de Melo Pimenta, com o intuito, portanto, de criticar seu próprio tio, desconstruindo a imagem positiva da qual discordava. No entanto, o artigo escrito por ele para rebater o discurso laudatório de Pimenta também recebe, por sua vez, uma réplica hostil, pois este o acusa de ingratidão, já que o sobrinho

17 Essa ideologia, aparentemente tão anacrônica, tem um histórico relativamente recente no Brasil (Maciel, 1999): em 1918 era criada a Sociedade Eugênica de São Paulo e em 1929 acontecia o $1^{\circ}$ Congresso Brasileiro de Eugenia, no Rio de Janeiro. Os defensores da eugenia acreditavam que fatores genéticos determinavam a situação de atraso do país, como se a miscigenação fosse capaz de justificar a condição de marginalização socioeconômica de uma camada cada vez maior da população. 
recebera do tio - o mesmo tio que agora publicamente critica - terras e dinheiro como herança:

Ingratidão maior não podia fazer o ilustre moço [Eduardo] a um homem que viveu 50 anos fazendo dinheiro na boca das fornalhas, espichando a casa dos Meneses, reconstruindo com mãos de calo o que os dedos finos dos barões arruinaram durante meio século de vida. (p.6)

Para não deixar de contra-atacar a acusação, a saída encontrada por Eduardo, após alterar-se e chegar a agredir Pimenta fisicamente - "Peguei o escriba de jeito e transferi para seus fundilhos meia dúzia de pontapés” (p.6) -, seria escrever o romance:

[...] eu imaginei uma vingança em regra. Escrever uns apanhados, um arrazoado, que mostrasse Frederico a olho nu. [...] Que tal um negócio escrito por mim que botasse a limpo a vida dos barões de São Martinho? [...] comecei a escurecer papel com minha letra miúda. Melo Pimenta não perdia por esperar. (p.6)

Desse modo, a partir de "O romance propriamente dito", a narrativa concretizaria uma vingança a seu agora inimigo Melo Pimenta, espécie de destinatário intratextual do relato. A desforra consistiria, portanto, em conseguir provar que seu tio não merecia a valoração que Pimenta lhe atribuíra no jornal. No entanto, há momentos do relato em que Eduardo perde o foco que a priori estabeleceu, ora cogitando mudar a direção de sua argumentação - "No princípio destes apanhados, mesmo dando a mão à palmatória de Melo Pimenta, pensei em fazer do meu tio um figurão, um segundo Pedra Lisa [...]" (p.15) -, ora realmente cedendo às razões de seu oponente e com ele concordando - "Não quero dar o braço a torcer. Quando falo de Melo Pimenta [...], sinto que perco o prumo e logo procuro embicar para outro assunto. Mas o escriba tem razão" (p.43).

Assim, a narrativa não se configura, por fim, como a revanche inicialmente planejada, pois o cumprimento dessa promessa de 
vingança acaba por não existir concretamente. Pode-se afirmar que o fracasso do intuito do narrador repercute na estrutura da narrativa, que acaba não atendendo ao desígnio com que fora criada e anunciada. Apesar disso, embora a narrativa não se complete em sua função, há, em sua estrutura, um retorno do narrador a um ponto próximo do qual partiu, como que fechando um ciclo, e isso se verifica por meio da observação de seu plano temporal. Atentar à organização temporal da narrativa auxilia na tarefa de compreender e sondar a imagem que o narrador Eduardo constrói de Frederico e, por extensão, a que constrói de si próprio, uma vez que falar de outro implica, também, se autorrevelar.

Considerando-se a relação entre o tempo da diegese e o tempo do discurso ou, ainda, "entre a ordem temporal da sucessão dos eventos na diegese e a ordem por que o discurso narrativo os produz" (Aguiar e Silva, 1991, p.751), a primeira parte ("Uma espécie de prefácio”) corresponderia a um momento adiantado da diegese. Esse momento inicial no discurso, mas avançado na história contada, encontraria correspondência com o final do romance, ponto no qual o narrador volta a assumir uma perspectiva próxima ao presente da narração, aparente na flexão dos verbos no presente: "Agora estou no fim. [...] Saio destes ermos de bolsos vazios" (Carvalho, 1974, p.125); além dos verbos que, também no presente, indicam uma prospecção ao futuro: "Arranjo um emprego público. Sigo o mesmo caminho de tio Nabuco, do primo Carlos de Sá Meneses. Um emprego público” (p.128). Dessa forma, início e término do romance emolduram o relato de Eduardo por meio da aproximação que manifestam em relação ao momento do presente da enunciação. ${ }^{18}$

No intervalo entre essas porções iniciais e finais do romance, o presente da narração volta à tona em várias passagens. Essa técnica

18 Utiliza-se aqui o termo enunciação como correspondente ao discurso do narrador, no sentido que, a partir das considerações de Gérard Genette, Paul Ricoeur (1995, p.161) desenvolveu o conceito: "Como autor do discurso, o narrador determina, de fato, um presente - o presente da narração -, tão fictício quanto a instância de discurso constitutiva da enunciação narrativa. [...] É esse o presente fictício que atribuímos ao autor fictício do discurso, ao narrador". 
difere-se da utilizada em $O$ coronel e o lobisomem, obra em que, propositalmente, quase se apaga o momento e as circunstâncias em que se constrói o discurso do narrador. Isso se faz necessário no romance de 1964, pois só ao final o leitor deverá descobrir que o coronel Ponciano, narrador, estava morto enquanto contava sua história. ${ }^{19}$ Já no romance de 1939, o presente da narração faz-se recorrente, como ilustra o excerto abaixo, extraído do sétimo capítulo, trecho em que o narrador realiza digressões metalinguísticas comentando o seu próprio ato de escrita:

Sei que é um defeito não escrever em ordem, colando um fato noutro. Às vezes, de um relato que ficou a outro que começa, vai distância longa de muitos anos. Por exemplo, dessa tarde de coruja e mandacaru até o aparecimento da usina São José correu tempo de alguns pares de anos. Deixo também de trabalhar de pincel em certos quadros porque não tenho jeito. Borro, encharco as coisas. O Tavares Gonzaga, do Monitor, quer que eu aperte a mão nas tintas. Fez com que eu lesse um livro que falava em tardes de "ouro e pedrarias". Achei tudo isso um disparate. Pelo que meti o pau no escrito. Gonzaga, apoiado no charuto, veio em defesa das "tardes de pedrarias”. Que eu era uma besta de chocalho. E brincalhão:

- O Barão de Sá Meneses é um bugre. Só falta a flecha.

Encurtando, escondi os pincéis e continuei o arrazoado. (p.32-3)

Afora passagens dessa natureza que retardam o andamento da ação, predomina no relato, a despeito da desordem alegada pelo narrador, a sequência linear e cronológica dos eventos, verificando-se apenas frequentes elipses, inerentes a qualquer narrativa. Tanto é que, passado o momento inicial elucidativo da circunstância motivadora da narração, a voz do narrador, no começo de "O romance propriamente dito", assume a perspectiva da personagem que, menino e depois jovem, vivenciou os fatos contados, e não mais do adulto que

19 Esta e outras questões serão aprofundadas no Capítulo 3, em que se analisa com maior verticalidade o romance $O$ coronel e o lobisomem. 
prefacia o livro. Em outros termos, reestabelece-se uma sequência cronológica dos fatos sob a perspectiva, na maior parte das vezes, da personagem que os vivenciou e não do narrador distanciado no tempo. Isso provoca na narrativa um efeito que, ao presentificar os eventos, relativiza o domínio e a autoridade do eu narrador em relação ao que seria a continuação de sua própria história, uma vez que ao contá-la encontra-se limitado à visão da personagem, ou seja, à perspectiva do eu narrado. Tal presentificação do discurso - recurso ainda mais intenso no romance de 1964 - confere certo frescor às memórias, fazendo que o leitor sinta-se acompanhando de perto o desenrolar dos fatos vividos em outra época pelo narrador, ${ }^{20}$ como se verifica no uso dos tempos verbais e marcadores temporais: "Não sei como não poquei de tanta saudade. [...] No São Martinho eu não teria os cuidados de algodão da minha tia Nica. [...] Agora só os olhos duros de Frederico" (p.11-2, grifo nosso).

Desse modo, para construir o retrato de seu tio Frederico, Eduardo rememora situações desde a sua infância, quando, órfão aos 10 anos de idade, passaria com ele a morar. A imagem de Frederico vai sendo, portanto, delineada aos poucos, à medida que Eduardo resgata ou julga, a partir de sua perspectiva e subjetividade, as situações que vivenciou. Com isso, a figura de Frederico adquire diferentes contornos ou interpretações em função dos diferentes momentos por que passa Eduardo e da consequente oscilação de sua percepção. Assim, o narrador descreve a figura de Frederico, inicialmente, sob o impacto das impressões que lhe causaram os comentários que ouvia, quando criança, na casa de outro familiar, seu tio Nabuco. Essas impressões, no entanto, são com o tempo desfeitas.

20 Acerca dessa instância narrativa, pautada na confluência do narrador homodiegético com a perspectiva centrada na personagem ao vivenciar os fatos, afirma Yves Reuter (2004, p.77): "Ele narra a sua história como se ela se desenrolasse no momento da narração. Constrói-se uma ilusão de simultaneidade entre os acontecimentos e sua narrativa (o que autoriza a utilização do presente). $\mathrm{O}$ narrador não está, portanto, distanciado do presente e sua visão se acha limitada, idêntica à da personagem que percebe o que lhe acontece no momento em que ocorre". 
Isto ocorre porque, sob o ponto de vista do então menino Eduardo, vai-se construindo uma imagem negativa, quase fantasmagórica, de Frederico: "Fazia meu tio um sujeito enorme, um gigante de história de gente velha. Talvez que ele quisesse engordar o sobrinho para a panela" (p.12). E, mais adiante: "Talvez que até Frederico fosse um morcego. [...] Frederico me esperaria de faca em punho, de caldeirão no fogo" (p.13). Essa imagem de Frederico criada pela imaginação do menino a partir de conversas ouvidas na casa de seu tio Nabuco, onde o equiparavam a um "segundo Judas" (p.12), é rejeitada mais tarde pelo mesmo Eduardo que, ao conviver com seu tio, percebe o quanto se enganara: "Mas logo vi que meu tio não era o demônio que a língua de Nabuco pintava nas conversas de rabo de mesa. Cuidei encontrar um gigante de dedos cabeludos. Puro engano" (p.14). Assim, os temores e angústias de Eduardo na infância vão sendo dissipados com o avanço do tempo diegético da narrativa, já que imperam as impressões e sensações do eu narrado (plano do enunciado), e não as do eu narrador, temporalmente distante dos eventos (plano da enunciação). ${ }^{21}$

Esse período em que viveu com o tio se estenderia por quinze anos. No entanto, apesar da longa convivência, Eduardo admite: "Nunca penetrei muito na alma ressequida de meu tio. [...] O diabo é que nunca pude abrir o cofre fechado que ele foi. O certo mesmo é apresentar meu tio como era, como viveu no São Martinho" (p.16-7). Conhecendo o restante do romance, o leitor poderá extrair dessas afirmações pelo menos duas conclusões: a primeira é que o próprio narrador, nos dois primeiros períodos do excerto, coloca sob suspeita a competência e a autoridade que possui para construir um retrato de seu tio; a segunda é que, ao mesmo tempo em que fornece essa pista ao leitor - ou seja, essa sinalização para que dele desconfie -, na continuação e na contramão dessa atitude, o narrador procura reestabelecer a confiabilidade de seu relato, afirmando que irá apresentar Frederico

21 Segundo Paul Ricoeur (1995, p.147-8), "a partir do momento em que se incorpora à diegese o discurso do personagem sobre sua experiência, é possível reformular o par enunciação-enunciado, [...] num vocabulário que personalize seus dois termos: a enunciação torna-se o discurso do narrador, enquanto o enunciado torna-se o discurso da personagem". 
tal "como era". O leitor deve, portanto, permanecer em alerta, mesmo porque outros indícios da não confiabilidade desse narrador emergem de seu próprio discurso: "[...] Tudo mentira, gosto de fabricar invenções. Não sei por que nasci assim. Ainda hoje essa doença toma conta de mim" (p.56). Essa tendência de Eduardo de "fabricar invenções" seria posteriormente aproveitada na caracterização da figura de Ponciano, tanto na crônica de 1958, quanto no romance de 1964.

Mantendo o narrador do romance de 1939 sob suspeita, percebe-se que Eduardo, ao recuperar os anos que passou com seu tio, por vezes trai a si mesmo em seu objetivo inicial de criticá-lo, pois começa a esboçar, no retrato que constrói de Frederico, não só defeitos, mas também, ao contrário do que almejava, algumas qualidades desse seu familiar. E, mais do que isso, Eduardo acaba relatando, sobre si mesmo, episódios que revelam aspectos negativos de sua índole, como o fato de, por exemplo, ter se relacionado adulteramente com a esposa do próprio tio enquanto vivia sob seu teto. Para Luís Bueno (2006, p.450), "Os melhores momentos do livro vão surgir das dificuldades que Eduardo tem ao julgar Frederico" e, pode-se acrescentar, pelo tanto que, com isso, denuncia si mesmo.

Com efeito, o fato de o narrador ser traído por seu próprio relato, ao não conseguir compor um quadro completamente negativo do tio, gera um impasse na narrativa que acaba por interferir na caracterização da personagem de Frederico. Este, ao mesmo tempo em que se mostra egoísta, avaro, apegado às suas terras, figura também, no relato de Eduardo, como um bom empreendedor e administrador, já que fora ele quem reerguera as posses dos Sá de Meneses, família até então chefiada por barões luxuosos e esbanjadores. Eduardo, por sua vez, já pobre ao final do romance, revela, sem necessariamente admitir ou aceitar, o quanto errou por não ter adquirido ao menos um pouco da conduta bem-sucedida de seu tio enquanto administrador de terras. O manejo dessa espécie de narrador infiel, ${ }^{22}$ que trai a si

22 Empresta-se aqui o conceito de narrador infiel do estudo Foco narrativo e fluxo de consciência: questões de teoria literária, em que Alfredo Leme Coelho de Carvalho explica (1981, p.47): "Nas narrativas de primeira pessoa pode ocorrer a figura do narrador infiel. Este é o narrador que nós percebemos que mente 
próprio em seu discurso, seria ainda aprimorado por José Cândido no romance de 1964, obra cujo narrador, além de participar da ação, também a protagoniza.

No primeiro romance do autor, o narrador, portanto, não se apresenta exatamente como protagonista da história, como já assinala o título ao mencionar o nome da personagem principal (Frederico). Assim, verifica-se a existência de um narrador em primeira pessoa (Eduardo), cuja participação no relato ocorre numa esfera secundária, já que busca enfocar e deslindar a imagem de seu tio sob uma perspectiva deliberadamente condenatória. No entanto, ao tentar fazê-lo, Eduardo falha: não apenas malogra no objetivo de construir uma imagem totalmente difamatória de Frederico, como também, o que é mais importante, acaba por se autorrevelar ao leitor, mostrando em seu discurso, à revelia de sua intenção, suas fragilidades, contradições e fracassos. Assim, Eduardo, enquanto tenta desmascarar seu tio, expõe suas próprias mazelas. Nesse sentido, o fracasso é definitivo, pois a narrativa, que constrói como última saída para concretizar o objetivo de denegrir a imagem de outro, volta-se sobre ele mesmo, envenenando sua própria imagem.

Para expor e condenar a figura do falecido tio Frederico, Eduardo contrasta-a com a imagem de seus antepassados barões, de modo que enquanto enobrece os barões de sua família, demonstra rejeição e menosprezo em relação a Frederico. Com isso, o leitor acaba por conhecer também os valores e a visão de mundo de Eduardo: "O mundo do meu tio era feito de terra. O meu era dos barões. Um mundo perdido, enterrado como o meu bisavô Pedra Lisa. Um mundo de romance" (Carvalho, 1974, p.26). O mundo "feito de terra" de Frederico equivale ao apego a sua propriedade, o engenho São Martinho. Daí, inclusive, o título do romance, que corresponde a uma frase constantemente dita por Padre Hugo ao advertir Frederico da necessidade de "olhar para o céu", ou seja, de preocupar-se com a

deliberadamente, ou que faz uma falsa ideia dos fatos que descreve, ou que tem de si mesmo um conceito diferente daquele que lhe é atribuído pelo autor implícito, ou, enfim, que se distancia deste em um ou mais eixos de comparação". 
vida espiritual, e não com a vida terrena dos bens materiais. Eduardo, por sua vez, vivia preso à idealização de uma aristocracia rural, a qual seus antepassados teriam pertencido, mas que, em sua época, já estaria desaparecendo. Como na percepção de Eduardo, em seu "mundo de barões", Frederico não estava à altura de ser representado num romance, o retrato de seu tio começa a ser composto por meio da técnica da preterição, recurso da retórica que consiste em fingir que não se quer falar de coisas sobre as quais se está, na verdade, falando:

Não posso fazer de Frederico uma figura de livro. Nunca teve um gesto, uma atitude que eternizasse sua vida em minha admiração. Pedra Lisa ainda hoje enche as nossas conversas com o açúcar de sua bondade. Perto do barão, Frederico é um anãozinho, um fio de gente. Vivi com meu tio perto de quinze anos. E estou vazio dele. Seu retrato está na sala de visitas. Um rosto murcho, com os ossos de fora, olhos pequeninos, tudo sem grandeza. Comparado com outros Meneses, parece trabalhador de bagaceira. (p.16, grifo nosso)

Pela comparação que estabelece, Eduardo revela ainda as razões latentes de seu desprezo pelo tio. No caso, compara-o a um "trabalhador de bagaceira", função que contrasta com a vida de nobreza, luxo e esbanjamento dos barões de sua família, os "outros Meneses" que admira. Isso demonstra que Eduardo, além de rememorar a trajetória de seus demais familiares de modo acrítico e idealizado, não considerava o trabalho como uma virtude, interessando-lhe, antes, a vida de hedonismo, ostentação e requinte dos outros barões do açúcar, que viviam então numa atmosfera de belle époque no Brasil:

Houve um Ricardo de Sá Meneses que assombrou com seus gastos de bolsa. Mandava vir atrizes do estrangeiro para esquentar sua cama alta de senhor de açúcar. Uma loucura de banquetes. Vinhos de preço em garrafas de cristal, conservas caras, mesa farta onde eram servidas as melhores comidas do mundo. (p.14) 
Neste ponto, convém frisar que elevados gastos, consumo de artigos importados de luxo e relações com prostitutas estrangeiras compuseram a realidade da elite brasileira do Rio de Janeiro no século XIX. Isso é o que conclui o historiador Jeffrey Needell em suas análises (1976; 1988). Segundo o pesquisador, com o fortalecimento das relações neocoloniais entre o país e as nações do hemisfério norte, especialmente após 1850 - período retratado no romance -, houve um aumento da absorção dos fenômenos culturais europeus por parte de uma elite brasileira, sobretudo a carioca (Needell, 1988). Entre os fenômenos assimilados, Needell destaca justamente os padrões de consumo, a moda do vestuário e as preferências sexuais (prostituição elegante) como aspectos reveladores de uma "fantasia eurófila" por parte da elite brasileira. Para esta, os paradigmas franco-ingleses de consumo corresponderiam a uma ideia de civilização e de cultura com a qual buscava-se acriticamente se identificar:

O que o consumidor carioca projetava nas mercadorias de luxo importadas era a mesma fantasia aristocrática dos burgueses europeus. Só que para os cariocas esta fantasia tinha um sentido diferente. No Rio, não se tratava de um simples caso de identificação de classe [uma vez que já pertenciam a uma elite] mas, sobretudo, de identificação cultural. O fetiche que os cariocas adoravam nos importados de luxo tinha a ver com ser um aristocrata europeu. (Needell, 1988, p.5, grifo nosso)

Assim, enquanto na Europa a burguesia emergente com o capitalismo aspira aos valores e padrões de comportamento de uma camada aristocrática da sociedade, no Brasil há uma elite que, ainda num contexto neocolonial, não dispõe de um referencial interno, passando, portanto, a buscar seu modelo nos códigos culturais europeus, tomando-os como paradigma de civilização. Como essa assimilação acontece, portanto, de modo descompassado, em função das diferentes conjunturas da elite rural brasileira em relação às da burguesia europeia, Needell (1988, p.11) considera essa identificação cultural como uma "fantasia de civilização": "Era o paralelo de um paradoxo 
maior - a realidade das relações entre o Brasil neocolonial e o Atlântico Norte casando-se com a fantasia de uma cultura franco-inglesa universal, a própria fantasia de civilização". Ressalte-se que isso explica igualmente a adesão irrefletida aos ideais de eugenia implícitos no preconceito de Eduardo.

Desse modo, pode-se entender o estilo de vida do senhor de engenho Ricardo de Sá, integrante de uma aristocracia agrária brasileira, como representação de um fenômeno da dinâmica econômica, social e cultural do país no período de transição entre o Império e a República. ${ }^{23}$ A ideologia dessa elite rural terá efeitos sobre os próprios comportamentos de Eduardo quando passa a administrar as terras de seu tio, como se verá mais detalhadamente adiante. Por enquanto, cumpre ressaltar que ambos os narradores dos romances de José Cândido - tanto Eduardo quanto Ponciano - passam por um período de transformação que, propiciado pela vivência no ambiente urbano, é marcado pela incorporação de hábitos de consumo e comportamentos associados a uma elite cujo paradigma cultural é o europeu. Por essa razão essas personagens investem na aparência, compram roupas sofisticadas, frequentam salões e teatros, envolvem-se com prostitutas e aderem a uma vida luxuosa, sem economias e afeita ao chamado fetichismo da mercadoria.

23 Para melhor aclarar o que está em perspectiva nesta leitura, convém recuperar a interpretação que, do ponto de vista sociológico, Florestan Fernandes (1976, p.27-8) faz do período em questão: "À medida que se intensifica a expansão da grande lavoura [...], gradualmente uma parcela em aumento crescente de 'senhores rurais' é extraída do isolamento do engenho ou da fazenda e projetada no cenário econômico das cidades - e no ambiente político da Corte ou dos Governos Provinciais. Por aí se deu o solapamento progressivo do tradicionalismo vinculado à dominação patrimonialista e começou a verdadeira desagregação econômica, social e política do sistema colonial. Essa porção de senhores rurais tendeu a secularizar suas ideias, suas concepções políticas e suas aspirações sociais; e, ao mesmo tempo, tendeu a urbanizar, em termos ou segundo padrões cosmopolitas, seu estilo de vida, revelando-se propensa a aceitar formas de organização da personalidade, das ações ou das relações sociais e das instituições econômicas, jurídicas e políticas que eram mal vistas e proscritas no passado. Em uma palavra, ela 'aburguesou-se', desempenhando uma função análoga a de certos segmentos da nobreza europeia na expansão do capitalismo”. 
De volta ao romance de 1939, é possível compreender melhor os valores de Eduardo e sua rejeição a Frederico, além de que passa a fazer sentido a afirmação de que seu mundo era o dos barões, enquanto o de seu tio era o da terra. Ainda nessa direção, embora Eduardo, ao longo da narrativa, se refira à linhagem tradicional de sua família evocando geralmente "os Meneses" ou "os barões" no plural, acaba por conferir maior destaque à imagem de seu bisavô Pedra Lisa para sintetizar a nobreza de seus antepassados. Também senhor de engenho, ou barão do açúcar, Pedra Lisa é lembrado ao longo do romance por sua bondade e generosidade - "grande de coração", “mão larga, mão de santo” (Carvalho, 1974, p.14) -, estabelecendo um contraponto com Frederico em sua vida "sem grandeza" (p.16), marcada por comportamentos interpretados por Eduardo como reflexo de miserabilidade e sovinice. Promovendo o contraste em relação à grandiosidade atribuída à memória de Pedra Lisa e dos demais Meneses, Eduardo salienta negativamente o comportamento sóbrio e a vida modesta de Frederico, voltada exclusivamente ao trabalho e às economias, associando-o insistentemente a elementos relacionados à pequenez, caracterização que vai ao encontro de seu intuito de diminuí-lo.

Assim, Frederico seria um sujeito "diminuído", "menor que um anão” (p.40), por não corresponder às expectativas de Eduardo, para quem um homem de comando deveria se impor, se fazer respeitar, zelar por sua honra e demonstrar social e publicamente seu poder. Frederico era o oposto dessas atitudes que lembram a ostentação de poder dos barões de sua família: falava baixo, mesmo com seus subalternos; era discreto, pois não dava demonstrações de seus lucros, pelo contrário, reclamava constantemente das dificuldades financeiras; ao invés de esbanjador e perdulário, era um poupador; com humildade, inferiorizava-se e fazia-se de vítima enquanto aumentava e enaltecia a força dos outros usineiros que conhecia; sem vaidades, suportava calado afrontas e provocações de parentes e vizinhos, de modo que, sem se alterar com seus rivais em momento inapropriado, fria e calculadamente esperava a melhor ocasião para agir, deixando-os antes convictos de sua tolice, para só depois surpreendê-los com suas artimanhas de administrador. 
Frederico mostrava-se humilde, bajulador e depreciava seu patrimônio enquanto valorizava o alheio: "A São José [propriedade de seu primo Carlos] é uma força danada. O primo, com o Araçá no papo, tem comida para duas usinas. Eu é que vivo penando nesta terra de formiga queimadeira" (p.36). Cauteloso, prudente e desconfiado com a modernidade, Frederico não investiu na transformação de seu engenho em usina. Matreiro, temia investir em maquinário e dizia a respeito do açúcar: "É negócio que não dá garantia a ninguém" (p.46). No entanto, evitando contrariar opiniões, não discordava dos que diziam ser a usina o futuro dos engenhos e até asseverava: "Estou cansado de avisar, de prevenir. Açúcar de forma [de engenho] deu o que tinha de dar. Está de vela na mão” (p.36). O vizinho Quincas de Barros, então dono de uma grande usina, ao ouvir isso, saía da casa de Frederico envaidecido com a confirmação de seu poder: "os elogios [...] pocavam no teto da sala mais que foguete de festa" (p.36).

Interessante é notar que Frederico não mudava seu discurso, criticando o elogiado depois que este se retirava; ao contrário, continuava a afirmar o mesmo, numa postura coerente com o que dissera, impossibilitando acusarem-no de falsidade. Desse modo, quieto, apequenando-se enquanto engrandecia os outros, foi crescendo sem ser notado, sem que cuidassem do perigo que poderia representar sua esperteza para os negócios. Frederico suportava, quando sabia ser proveitoso, até mesmo o vizinho Quincas avançando os limites das cercas sob sua propriedade. Dava-se por desentendido, dizia ser boato, mesmo sabendo da verdade: "Sua fala era mole, fala mansa que não levava vigor. [...] E nenhum sinal de raiva no rosto de Frederico. O mesmo de sempre. Até parecia que o usineiro estava fazendo negócio vantajoso para ele. Sujeito sem sangue!” (p.39). Já Dona Lúcia, estouvada, impaciente e sem compreender as razões de tal passividade, reclamava da falta de autoridade do marido. Ele, de cabeça baixa e fala mansa, nada fazia, e ela, enérgica e impositiva, enfrentava o desaforo do vizinho usineiro: "A grandeza de Dona Lúcia cobria tudo. [...] E meu tio? Um diminuído, um degradado. [...] Menor que um anão” (p.40).

Confirmando a cautela de Frederico, Barros e muitos dos que apressadamente modernizaram seus engenhos com auxílio de capital 
estrangeiro, viram-se, com a chegada da seca, assolados por dívidas, consequência da falta de cana-de-açúcar para manter a produção e os lucros que demanda uma usina. Ardiloso, Frederico, como que montando as peças de um quebra-cabeça, conseguiu antever o futuro dos negócios e se preparar para esse momento. Assim, sabendo da vantagem que certamente teria, emprestou dinheiro a seu primo Carlos, dono de uma propriedade que fornecia cana-de-açúcar a Barros. Sem conseguir recuperar o capital e pagar Frederico, Carlos acabaria por lhe entregar sua propriedade por uma quantia irrisória. Com isso, como era Carlos o principal fornecedor de cana a Barros, Frederico, agora dono da propriedade que era de seu primo, passa a deter o controle da produção, colocando o grande usineiro em sua dependência: "Agora essa arrogância [de Barros] estava presa na munheca de Frederico" (p.63). Apesar da seca também afetar a produção do São Martinho, sem uma usina que abastecer e também sem credores estrangeiros a quem prestar contas, Frederico não sofreu os mesmos prejuízos de Barros.

Por esses episódios, Eduardo compreenderia melhor, com o passar do tempo, as motivações que se escondiam por detrás dos comportamentos e da aparência de fraqueza de seu tio e, fracassando em seu intuito, teria de admitir:

Por baixo de sua moleza, dos gestos de caracol, havia uma raposa de mil astúcias. As paredes do São Martinho, que viram barões, nunca tiveram um capitão de batalha como Frederico. Houve um valentão como sinhozinho de Sá, um santo como o barão de Pedra Lisa e um verrumador de donzela como Afonso de Meneses, que foi até doutor. A força de Frederico era de outro jeito. Não tinha olhos para as belezas de dona Lúcia, nem perdeu tempo como os veludos dos brasões do São Martinho. Suas raízes vinham do barro. Só teve carinho para o açúcar que saía das tachas. (p.43)

Agindo de maneira diferente dos demais barões, sob a aparência de fraco e inofensivo, Frederico mantinha, portanto, a estabilidade e o crescimento financeiro de seus negócios: "Faço questão de dizer 
que esses modos mansos de Frederico enganaram meio mundo, jogaram muita gente no barro" (p.43). Eduardo afirma ainda que Frederico "papava as terras dos parentes pobres almoçando com eles na mesa" (p.48) já que, com suas manobras, era capaz de preservar-lhes a afeição - "A língua do meu tio adoçava tudo" (p.49) -, a ponto de sentirem-se ainda gratos a ele. Por essa astúcia do tio, Eduardo compara-o, com frequência, à imagem da raposa. Além disso, diria também a respeito do tio, em função de sua dissimulação, esperteza e tino para manter os negócios sem criar rivalidades: "Frederico sabia esconder as unhas. Era gavião que voava feito andorinha” (p.48).

Apesar de todo seu empenho em criticar o tio, ao resgatar a trajetória de Frederico, Eduardo acaba por rever seus juízos e admitir: "Hoje, que o tempo passou, vejo melhor esse meu tio de São Martinho. Não foi um pé de pau qualquer como apregoava José Nabuco. É bem verdade que não foi um senhor de açúcar como eu queria que fosse. Nada da grandeza dos outros Meneses" (p.47, grifo nosso). Como se verifica, além de relativizar as condenações que fizera a seu tio, Eduardo deixa transparecer em suas ponderações suas próprias ambições (frustradas), pois era dele o desejo de que Frederico fosse um nobre senhor do açúcar. Não só isso, ele próprio desejava ter sido um homem de poder, aspiração que já na infância se anunciava:

Gostava de falar desses nomes compridos: Antonio Joaquim de Melo e Sá Meneses, barão da Pedra Lisa. [...] Me via senhor de fornalha, de casaca e barba embutida no rosto branco. E na sala dos retratos, em frente dos meus parentes barbudos, eu dizia alto o nome de cada um:

- Aqui Saturnino Amarante de Sá Meneses, que furou muita barriga de paraguaio nas brigas do Lopes. O primeiro barãozão da família. (p.18) $)^{24}$

24 Note-se que a menção à Guerra do Paraguai surge, como também acontece na crônica "O major", em um contexto que remete à figura do contador de histórias. Em ambos os casos essa figura é evocada em tom de burla ou desconfiança, ao exemplificar pretensos feitos de nobreza e valentia das personagens. 
Esse futuro aristocrático que o menino Eduardo vislumbrava para si mesmo terminaria, ironicamente, na pretensão - que o leitor acaba não sabendo se seria ou não concretizada - de se obter um emprego público, função que a narrativa expõe como medíocre e parasitária, pela ideia de "mamar no governo" (p.127), posição desprovida, portanto, do resplendor por ele idealizado. Mas, antes de chegar a esse ponto ápice de sua derrocada, o acusador Eduardo parece incorrer nos mesmos erros de Frederico, sobretudo nos mais condenáveis, sem, no entanto, absorver-lhe os aspectos positivos. Mais do que isso, Eduardo parece reunir o que houve de pior não só em Frederico, mas também nos barões de sua família. Por outro lado, as virtudes tanto de um quanto de outros, Eduardo não as alcançaria. Por fim, seu relato só confirma as acusações de Melo Pimenta, ao invés de negá-las, como era o propósito com que foi criado.

Como Eduardo conta sua história da infância à maturidade, a narrativa abarca as diferentes fases e as transformações pelas quais passou: "Cresci muito. [...] eu aprendia coisas sem conta" (p.2930). Essa estrutura teleológica pautada na trajetória de aprendizagem do narrador permite pensar numa apropriação da tradição do Bildungsroman [romance de formação]. ${ }^{25}$ De menino órfão, triste, supersticioso, ligado ao catolicismo e à devoção aos santos, Eduardo, ainda aos 10 anos, vai morar com o seu tio, no São Martinho. Em uma paisagem que lembra em muito a nordestina, com engenhos

25 Sem desconsiderar a complexidade e as nuances do conceito, utiliza-se aqui o termo Bildungsroman, tomando-se por base a definição de Luísa Flora ([20-- ]), no E-Dicionário de Termos Literários, ao se pautar nas características consideradas por Dilthey como as mais marcantes do paradigmático romance $O s$ anos de aprendizagem de Wilhelm Meister: "O protagonista é uma personagem jovem, do sexo masculino (às mulheres não era, na época, possível a liberdade de movimentos que permite ao herói o contacto com múltiplas experiências sociais decisivas no percurso de autoconhecimento), que começa a sua viagem de formação em conflito com o meio em que vive, determinado em afrontá-lo e recusando uma atitude passiva; deixa-se marcar pelos acontecimentos e aprende com eles, tem por mestre o mundo e atinge a maturidade integrando no seu carácter as experiências pelas quais vai passando; em constante demanda da sua identidade, representa diferentes papéis e usa diferentes máscaras; sofre pelo imenso contraste entre a vida que idealizou e a realidade que terá de viver [...]”. 
de açúcar, mandacarus e cajueiros, passa a adolescência. Nesse período, tem a sexualidade despertada por Lúcia, a moça de 20 anos com quem Frederico casara-se. Como seria também Esmeraldina, personagem feminina de destaque no romance de 1964, Dona Lúcia é uma mulher de personalidade forte, sedutora, pouco decorosa e em nada romantizada. Eduardo sente-se, como ocorreria também com Ponciano, um joguete nas mãos da mulher:

O que doía, o que picava em mim mais que espinho brabo, era a secura de dona Lúcia. Queria que ela tivesse palavras de meiguice, dissesse coisas de namorada. Mas a senhora do São Martinho era feita de outro barro. Dura. Nada das doidices das moças dos romances. Fazia de mim sua serventia, como se eu fosse um moleque de cozinha. [...] A verdade é que a senhora do São Martinho dominava minha vontade. Em seu poder eu era um boneco de engonço. (p.54-5)

O envolvimento de Eduardo com a esposa de seu tio lhe traria sentimentos de culpa, remorso, medo e o afastaria da vida espiritual que nutria na infância: "Não é para incriminar ninguém, mas Dona Lúcia era um bocado de mau destino. Retirou de mim os santos, fiquei vazio de Deus" (p.44). Sentindo-se cada vez mais desprotegido e amedrontado com a possibilidade de ser descoberto em sua traição, Eduardo começa a imaginar e temer a presença de Frederico:

O diabo é que em todo o canto eu via os olhos de Frederico. Olhos gastos, vermelhos de tanto fogo de fornalha. Talvez que até o barulho que vinha dos matos fosse meu tio pisando gravetos. [...] Que diria se visse o sobrinho nesse serviço de safadeza? Eu era um degradado, um pecador que nem toda a bondade de padre Hugo limparia em muitos anos. (p.44-5)

Nesse ponto já é possível notar uma inversão bastante significativa. A recomendação do padre Hugo a Frederico, que serve de título à obra, passa a ser válida também para o "degradado" e "pecador" Eduardo. Com a morte de Frederico, que, num gesto de bondade, 
deixa-lhe a herança, agrava-se a evidência da ingratidão de Eduardo. Ele, agora, à frente do comando do engenho São Martinho sente-se poderoso e autossuficiente, manda inclusive retirar o retrato de Frederico da sala de sua casa. O poder torna-o ainda arrogante - "[...] tomei gosto pelo berro" (p.90) -, impositivo, agressivo e impiedoso para com seus subjulgados. Eduardo criticava seu tio pela sovinice, mas ele mesmo, ao passar a administrar as terras que seu tio lhe deixa, torna-se pior em muitos sentidos. Nesse ponto da narrativa, ele se compara a Frederico aos vinte anos, como forma de explicar o quanto se encontrava entusiasmado com a propriedade e a gestão dos negócios, o domínio faria dele uma pessoa cruel e mesquinha.

Por meio da personagem de Eduardo, enquanto representante de uma elite rural, percebe-se na narrativa uma crítica social aos desmandos dos poderosos e às condições de subumanidade de seus dependentes. A exploração das classes inferiores por uma elite rural foi uma das tônicas do romance de 1930 e tal temática que toca diretamente no problema do subdesenvolvimento do país se mantém nesse romance de José Cândido, derradeiro da década. Eduardo, sem embargos, revela: "Trabalhador comigo deixava o couro nas esteiras ou no corte da cana. [...] Lavava as mãos. Não tinha nada com as desgraças do povo, com a meninada empanzinada de vermes" (p.101). Os agregados de suas plantações chegam a denunciá-lo pelos maus tratos que padeciam em suas terras. Dona Lúcia, a quem Frederico também destinou parte da herança, condenava esses comportamentos de Eduardo. Numa reação que faz lembrar o inconformismo da personagem Madalena, esposa de Paulo Honório, do romance São Bernardo, Lúcia acusa Eduardo de ser um carrasco, de faltar-lhe "coração" e compara-o a Frederico: "Que Frederico, perto de mim [de Eduardo], era um anjo com asinhas de veludo" (p.101).

Ainda durante esse momento de euforia, em que estava entusiasmado com a administração da propriedade e ocupado em cortar gastos, Eduardo transforma o engenho de São Martinho em usina, convencido da lucratividade do empreendimento pelo representante de uma empresa alemã - fato que representa, também como é usual no romance de 1930, a entrada de capital estrangeiro no 
país. Contrariando a opinião do pai de Lúcia e do mestre de açúcar do São Martinho, Eduardo sentia que modernizando o engenho se afastaria do atraso que associava a seu tio, por conta da cautela e receio deste diante das transformações. Mas, ao contrário do que esperava, inicia-se aí sua trajetória de decadência. Conquistando visibilidade social por sua usina, Eduardo se envaidece com os artigos que seu amigo Gonzaga publica no jornal comentando o poder do novo usineiro. Para não perder essa notoriedade pública, ele lança mão até de mecanismos ilegais como forma de garantir sua expansão econômica, conforme revela ao afirmar: "Abocanhei uns pastos a poder de escrituras falsificadas" (p.102). Embora Eduardo acusasse Frederico de ser um "comedor de terras", nota-se que seu tio ao menos se mantinha na legalidade, de modo que suas conquistas davam-se antes por astúcia e planejamento do que por falcatruas, como faria o sobrinho.

Com essas inclinações, Eduardo trilha um caminho semelhante ao dos barões vaidosos, esbanjadores e inconsequentes de sua família. O coronel Ponciano também teria sua trajetória de queda demarcada pela mudança de espaço e interesses, transição do comando do meio rural para as distrações e prazeres da vida urbana voltada ao luxo dos teatros e à preocupação com a aparência. Do mesmo modo, Eduardo começa a descuidar dos negócios e passa a gastar muito dinheiro na cidade de Campos, onde leva uma vida boêmia, vivenciando a mencionada fantasia de civilização das elites, frequentando o "Café High-Life" e pensões "de porta aberta" (p.102). Em uma dessas ocasiões, em companhia de seu amigo Gonzaga, Eduardo embriagado revela seu desejo de poder e afirmação de uma pretensa superioridade social: "Fiquei alterado. Gritei que era barão, bisneto de Pedra Lisa. E na mesma hora quis abrir as veias para que vissem a cor do meu sangue. O sangue azul dos Sá de Meneses” (p.103). Essa atitude lembra os arroubos de Rubião ao herdar a herança de Quincas Borba, no romance de Machado de Assis, e também o comportamento do também herdeiro coronel Ponciano quando, negando sua derrocada, rasga dinheiro e grita com as pessoas pela rua, convicto de que estivessem dele zombando. 
Eduardo, ainda nesse período, envolve-se com Luísa, prostituta a quem passa a sustentar. Por outro lado, a imagem pública que procurava construir de si era a de homem bom e honrado. Para tanto, utilizava novamente os jornais com a ajuda de Gonzaga, que publica notícias falsas sobre doações a carentes por parte de Eduardo, apontando-o como "grande continuador das tradições de nobreza dos Sás Meneses” (p.105). Na realidade, as doações nunca existiram e não havia, portanto, razões para o enaltecer. Também por meio de farsas, envolve-se na política, prometendo benefícios ilusórios aos pobres e conquistando, com isso, eleitores. Por criticar o governo nos jornais, como parte da estratégia de alcançar notoriedade entre o povo, passa a ter despesas com fiscais e multas. Com o mau andamento dos negócios, uma vez que sua propriedade ficara entregue à negligência $e$ má administração do irmão de Luísa, Eduardo endivida-se, precisando fazer empréstimos nos bancos.

Nesse ponto, a semelhança com Ponciano também se evidencia, pois Eduardo se vê igualmente manipulado por uma mulher que o leva a entregar o controle de suas terras a alguém inábil e descomprometido com o trabalho, fator decisivo para a ruína de ambas as personagens. Assim como Ponciano que, quando arruinado, seria afrontado por seus empregados, Eduardo perde a consideração e o respeito de seus subalternos, sendo inclusive insultado pelo encarregado de cuidar de suas terras, que lhe diz aos berros: "Barão feito nas coxas, barão de meia cuia" (p.125). Diante dessa humilhação, já ao final do romance, Eduardo não consegue esboçar nenhuma reação sequer, apenas recorre à imagem de Frederico, reafirmando a própria incapacidade para exercer o trabalho e, consequentemente, sua inferioridade diante do tio: "Sentado estava, sentado fiquei. Em que lugar andava Frederico que não vinha tomar conta de seus pertences? Felisberto dava as ordens, o irmão de Luísa é quem mandava e desmandava. O São Martinho agonizava” (p.125).

Eduardo não consegue se desvencilhar da imagem de Frederico e, com isso, a presença de seu tio se impõe ao longo da narrativa mesmo após sua morte: "O casarão dos Sás Meneses, enterrado na noite, era de meter medo. Em todo lugar eu via Frederico, os olhos 
de pitanga de meu tio. Não metia rifle de vigia no lado de fora só para não dar parte de fraco" (p.121). Assim, contrariando os intuitos de Eduardo, Frederico sobrepõe-se ao sobrinho, revelando-se, mesmo morto, mais forte e incólume às críticas do que ele, a despeito de sua autoridade discursiva. Vale lembrar que, também em vida do tio, Eduardo sentia-se vigiado, em decorrência dos sentimentos de culpa e medo que experimentava em momentos de intimidade com Lúcia: "O diabo é que em todo o canto eu via os olhos de Frederico. Olhos gastos, vermelhos de tanto fogo de fornalha" (p.44).

O término de Eduardo é, portanto, marcado pela pobreza, solidão e humilhação, sintomas que, se opondo a seus anseios e expectativas iniciais, configuram seu fracasso. Nesse momento, cria-se um efeito irônico pela distância entre as aspirações da personagem, devido ao sentimento de continuidade aristocrática e o desejo de envelhecer integrando uma elite social, e o final efetivo de sua trajetória, desprovido de qualquer mérito ou grandeza:

Agora estou no fim. A usina morreu no princípio do verão. [...] Saio destes ermos de bolso vazio. [...] Não adiantou nada meu vozeirão de arrebentar cristaleira. Ontem, rente ao espelho, fiz um exame de minha pessoa. Eu era um anão de gente, capaz de caber num dedal. Mãos vazias, murchas. Se morresse agora embarcaria como um joão-ninguém. Nem os santos eu tenho mais, que o gosto deles perdi faz muito tempo. Às vezes, cuido ouvir o riso encardido de Frederico. Estou barbado mais que um barão. Uma tarde dessas, estando eu na varanda, um moleque passou e gritou:

- Olha o maluco! Tem doido lá em cima.

[...] Levo na mala os rabiscos que escureci nas noites de São Martinho. (p.129-30)

O narrador, agora no último capítulo, atribui a si mesmo a imagem da pequenez; percebe a inutilidade de seus modos arrogantes; pela pobreza em que se encontra, julga-se sem valor; sente-se abandonado pelos santos e atormentado pela lembrança de Frederico; com a barba grande que em nada remete à altivez dos antigos barões, 
mas sim seu processo de degeneração, tolera calado demonstrações de desrespeito e humilhação dos que o cercam. Essa cena, aliás, lembra muito a situação enfrentada pelo Capitão Vitorino Carneiro da Cunha, personagem de Fogo Morto (publicado em 1943), de José Lins do Rego, com a diferença de que este, assim como Ponciano, conquista a empatia do leitor. Após o reconhecimento da situação em que se encontra, Eduardo, um tanto digressiva e caoticamente, comenta fatos do passado, o estado de outras pessoas no presente e os planos para o futuro:

Amanhã embarco para o mundo. [...] Nem sei em que oco anda padre Hugo. Procuro os santos e eles não aparecem. Mais de uma vez ouvi passos nos corredores e na sala de visitas. O vento no São Martinho é astucioso. Faz da noite o que bem quer. Detesto pio de coruja. Bem que eu podia ter um nome comprido: Visconde Eduardo Noronha de Sá Álvares Meneses. (p.126-7)

Estas e outras informações são dispostas um tanto aleatoriamente, como que acompanhando o fluxo de raciocínio do narrador, que está então confuso e se vê incapaz de realizar com clareza um balanço de sua vida e traçar um projeto para o futuro. Eduardo menciona, entre outros planos, a obtenção de um emprego - "O Dr. Abelha Figueiredo, que ajudei a subir na política, diz que vai arranjar para mim um posto de quinhentos réis por mês numa repartição do governo" (p.126, grifo nosso) - e uma aliança conjugal - "Entro no uso e no gozo de Naninha de Sousa. São duzentos pacotes que a menina traz por entre flores de laranjeira. Não preciso mais de usina, de Fredericos que trabalhem para mim" (p.127). O leitor, porém, percebe que esse futuro desejado, apesar de possível, é ainda incerto. Isto porque, com relação ao casamento, por exemplo, seu plano já quase fracassara anteriormente, quando Naninha, moça apaixonada por ele e proveniente de família abastada, avisa-o de que seu pai já se opunha ao enlace pela demora do pretendente em se manifestar conclusivamente.

A verdade é que, pelo distanciamento do autor fictício em relação ao narrador, o leitor compreende que o destino de Eduardo, apesar 
de suas convicções, é agora instável. Em todo o caso, ainda na melhor das hipóteses, se terminasse conforme planeja, poder-se-ia supor uma vida medíocre, utilitária e parasitária, uma vez que já revelara ser indiferente aos sentimentos de Naninha e via com desprezo o emprego público. Com isso, entende-se que a submissão a essas circunstâncias só se deve a interesse, conveniência e falta de opções mais vantajosas. Portanto, do mesmo modo que pretende parasitar o governo, conta com os lucros que, na metonímia dos "duzentos pacotes", o casamento por conveniência com Naninha poderia lhe render. E seria esse o "nobre" final da vida de Eduardo.

Como é possível constatar, Olha para o céu, Frederico! apresenta muitos pontos de contato com $O$ coronel e o lobisomem. Há, entre as obras, semelhanças em relação ao gênero, ao universo temático, à localização espaço-temporal das histórias, ao tipo de foco narrativo, à caracterização das personagens, aos detalhes do enredo e, ainda, ao estilo. Sobre este último item - até o momento não comentado, mas talvez perceptível pela transcrição de trechos do romance -, frise-se que há marcas evidentes de uma proximidade estilística entre as obras, principalmente pela utilização de expressões e neologismos do romance de estreia, como "poucocasista", "a bem dizer", "labutas dos travesseiros", "pensão de porta aberta", que conferem certo grau de humor à narrativa e assinalam o estilo bastante peculiar da prosa do autor. Por esses fatores, torna-se inegável a existência de certa permanência temática e mesmo formal entre uma obra e outra, permitindo-se visualizar uma linha que as une no interior do projeto estético do autor.

Se os pontos de contato entre as obras de José Cândido lhes garantem o reconhecimento de uma continuidade, as similaridades, contudo, não são tão profundas que permitam aos romances serem equiparados em todas as suas dimensões. E, como o interesse é definir o que representa o romance $O$ coronel e o lobisomem em sua especificidade, no interior da produção carvalhiana e, por extensão, no panorama da literatura brasileira, faz-se necessário procurar, para além das semelhanças, os pontos de divergência entre esse livro e aquele que o antecedeu em longa data. Nesse sentido, pode-se notar 
que, apesar das proximidades, houve no romance de 1964 um aprimoramento ou, pelo menos, uma transformação relativa a muitas das categorias mencionadas, que resultaram na composição de um romance de maior tensão e refinamento estético. Sem pretender realizar, por ora, uma análise do romance $O$ coronel e o lobisomem, o que se fará no último capítulo deste trabalho, pode-se ao menos antecipar algumas constatações sobre as dissociações mais evidentes tendo-se em vista, principalmente, o cotejo da obra com o livro de estreia.

No plano das personagens, por exemplo, Eduardo e Ponciano contrastam em pontos cruciais de suas caracterizações, sobretudo quanto aos valores morais, o que altera profundamente a intensidade dos dramas por eles vividos e as saídas que lhes são possíveis. Apesar de ambos serem representantes de uma elite agrária e se depararem com conflitos econômicos, sociais e culturais bastante semelhantes em suas trajetórias, Eduardo é altamente mesquinho e despótico em relação àqueles que lhe são inferiores socialmente, enquanto Ponciano é generoso e solidário com os mais humildes e indefesos, promovendo identificação e empatia por parte do leitor. Se Eduardo, em certo momento, manda surrar um menino que anda lhe roubando frutas da propriedade, Ponciano salva de qualquer punição um rapaz que fora encarregado de lhe matar, por se apiedar das condições de miséria que levaram o garoto a aceitar o trabalho oferecido por um homem poderoso e do qual o garoto dependia.

Sobre isso, convém aclarar que os diferentes critérios por que os narradores definem as ideias de grandiosidade ou pequenez, recorrentes para julgarem a si e aos outros, revelam também o distanciamento existente entre seus valores morais. Para Eduardo, as ideias de pequenez e grandeza são aplicadas em vista das posses e da ostentação do status social das pessoas, de modo que a pequenez, para ele, está associada à pobreza, à simplicidade, à humildade e ao trabalho, e a grandeza, à riqueza e à demonstração de poder e autoridade. Já para Ponciano, as noções de pequenez e grandeza baseiam-se nos valores de justiça ou injustiça em que acredita, e que corresponderiam à índole das pessoas. Com isso, pode-se notar, inclusive, que a exaltação da sua imagem e sua autoassociação a elementos de grandeza 
(Ponciano se descreve como homem alto, robusto, de barba grande e voz grossa) decorrem menos de uma superioridade e vaidade gratuitas e mais dos valores que demonstra possuir: para Ponciano, a grandeza do porte físico deve estar associada ao valor do caráter. Um exemplo que pode ilustrar essa constatação encontra-se no seguinte trecho em que o herói, tentando fazer justiça, tal como um coronel quixotesco, ${ }^{26}$ condena a covardia da atitude de Pedro Braga, personagem que batera em uma criança:

- Então, vosmecê, com esse calibre todo, é o tal de Pedro Braga, judiador dos pobrinhos dos currais?

E dedo apontado para os seus avantajados de tamanho, com cara de nojo, fiz ver o grandalhão que foi um desperdício de Nosso Senhor Jesus Cristo botar em cima das suas botinas uma grandezona assim de dois metros. É que o povo do céu queria fazer dele uma palmeirona, coisa de brigar contra o vento brabo e o corisco ardiloso, mas que ele, pelos seus procedidos, tinha deitado tudo a perder, estragado tão bela obra da nascença:

- A bem dizer, vosmecê encolheu como chita ordinária. É um toquinho de gente, seu Pedro Braga. Vosmecê virou anão, Seu Pedro Braga. (Carvalho, 1983, p.145)

$\mathrm{O}$ fato de Ponciano frequentemente engrandecer-se e tentar mostrar certa superioridade não prejudica sua própria imagem; antes de ser uma atitude de arrogância e soberba, como ocorre na personagem Eduardo, ela acaba por revelar os valores que Ponciano possui e toma como ideal.

Assim, ao final das narrativas, enquanto Eduardo, apesar da ruína, ainda entrevê um caminho possível (o emprego público e o casamento por conveniência) - saída medíocre, mas por isso mesmo em sintonia com seu caráter -, a Ponciano, como espécie de herói trágico em sua grandiosidade, resta a morte, dada sua inadaptação

26 O tema do quixotesco em $O$ coronel e o lobisomem e em Fogo morto foi amplamente abordado na tese de Eunice Prudenciano de Souza (2010). 
aos valores de um novo tempo. Porém, sua história não acaba aí - e talvez nisso resida o principal motivo do distanciamento entre as obras: Ponciano refaz-se num mundo fantasioso do além-túmulo, um mundo mágico, tal como o universo (imaginário?) em que, em vida, transcorriam suas aventuras.

O "término" da trajetória de Ponciano contribui para a construção de uma dimensão insólita ao romance, uma vez que o herói narra sua própria experiência de morte (e de pós-morte), mesmo sem dela ter plena consciência. Assim, depois de sentir uma forte dor no peito, então num plano do além-vida, Ponciano se encontra com conhecidos seus já falecidos, que estão com asas de anjos, e ele, livre de todas as suas aflições anteriores, também como um ser mágico emanando luz, montado em uma "mulinha de guerra" ("prenda" de São Jorge, santo de sua devoção), sai em disparada no encalço do demônio, pois "ia travar luta mortal contra o pai de todas as maldades" (Carvalho, 1983, p.304).

Esse final, revelador das circunstâncias em que se constrói o discurso do narrador, não garante por si só toda a atmosfera mágica do romance. Nesse sentido, dentre as peculiaridades desse romance que o afastam da obra de estreia, a mais notável apresenta-se já no título, dada sua importância no conjunto da narrativa: trata-se da presença do lobisomem enquanto representante de um universo lendário que permeará o relato do coronel Ponciano. Junto dele, surgem ainda outros seres do repertório mitológico universal e brasileiro, como a sereia e o ururau, aparecendo em meio ao "sertão" fluminense ou aos "ermos", expressões frequentemente utilizadas para designar a espacialidade rural da história. Além desses componentes folclóricos relacionados ao misticismo popular e à tradição da narrativa oral, Ponciano relata também aparições de fantasmas de sua família, como a de seu avô Simeão. Afora episódios dessa natureza, mesmo o galo Vermelhinho, o "Pé de Pilão", adquire contornos fantasiosos em vista de suas habilidades, força e façanhas que ultrapassam os limites de uma realidade convencional ou possível.

Por esses aspectos, verifica-se no romance $O$ coronel e o lobisomem uma sensível ruptura com o tipo de representação realista 
existente em Olha para o céu, Frederico!. Nesse romance de estreia, o que mais se aproxima de uma dimensão não realista são as imagens construídas pela imaginação infantil do amedrontado Eduardo, bem como suas crenças ligadas ao catolicismo, sendo que estas, evocadas também pelo título, enfraquecem-se com sua trajetória de declínio. ${ }^{27}$ A figura do lobisomem chega a ser mencionada nesse primeiro romance, mas de modo passageiro, como um mero detalhe de uma narrativa secundária, parte de uma história (um dos "causos") que Frederico gostava de contar sobre os atos de valentia de seu sogro. Assim, apesar de se anunciarem, são escassos, esparsos e de pouca relevância esses elementos que, no primeiro romance do autor, podem ser associados a uma realidade extraordinária. Desse modo, parece viável afirmar, em consonância com as relações já estabelecidas pela crítica e aqui mencionadas, que o romance de 1939 se mantém próximo à produção regionalista dos anos 1930 por aderir a um paradigma de representação realista característico da tendência, que, não por acaso, também foi chamada de "neorrealismo" (Bosi, 1974, p.479). O livro de 1964, por sua vez, a despeito das semelhanças que guarda em relação ao de 1939, em especial pela manutenção da mesma ambientação rural e do caráter central de muitos dos conflitos a ela inerentes, dele se afastaria e, por extensão, da estética dos anos 1930, não apenas por sua localização temporal, mas principalmente pela incorporação de uma dimensão insólita à narrativa.

Estaria nisto, então, a razão de escritores e críticos afirmarem que o romance $O$ coronel e o lobisomem foi capaz de renovar o regionalismo literário brasileiro? Ou seria essa renovação, promovida pelo romance, uma ruptura definitiva com a vertente regionalista? $\mathrm{Ou}$ ainda, levando a especulação ao extremo, o regionalismo nunca teria existido e seria um equívoco ou anacronismo da crítica utilizá-lo

27 A inclinação religiosa de Eduardo na infância e adolescência deve-se, na narrativa, ao fato de ter estudado sob a orientação de padres, que lhe ensinavam "as letras" por meio das hagiografias; daí, então, seu encantamento pela vida dos santos católicos. José Aderaldo Castello (1999, p.327), ao tratar de outro romance da década de 1930, lembra que era comum, ainda nesse período, o ensino particular estar subordinado a ordens religiosas. 
para pensar a obra de José Cândido? Admitindo-se a pertinência do conceito, como falar em regionalismo para tratar de uma obra que surge após o aparecimento da prosa de Guimarães Rosa, lembrada pela superação do regional? Antes de apresentar uma proposta para a resolução - ainda que parcial - dessas questões, certamente relevantes para se pensar o caminho da prosa ficcional brasileira em meados do século XX, convém recuperar o modo como a fortuna crítica de José Cândido lidou com esses impasses. Nessa linha de raciocínio, convém, portanto, traçar um panorama que demonstre como a crítica situou a obra do campista no cenário literário, se e como abordou a possível inovação/superação de tendências e a que exatamente a atribuiu (ao insólito, à linguagem, à superação do regionalismo?). Partindo das leituras críticas da obra, problematizando-as, ampliando-as e atualizando-as, espera-se, ao final, propor uma abordagem ao menos renovada do romance de José Cândido de Carvalho, capaz de iluminá-lo e, com isso, esclarecer também as nuances que conferem ao momento estético no qual se inscreve. 


\section{2 \\ O LOBISOMEM NAS VEREDAS DA LITERATURA REGIONALISTA BRASILEIRA: IMPASSES DA FORTUNA CRÍTICA DE O CORONEL E O LOBISOMEM}

Em vez de iniciar esse percurso pela fortuna crítica de maneira cronológica, começando pelas resenhas de jornais da época, parece conveniente e mais produtivo primeiro se perguntar: o que leria sobre o romance $O$ coronel e o lobisomem quem hoje consultasse obras de referência da historiografia literária brasileira?

Uma breve consulta a publicações dessa natureza evidencia o pouco espaço concedido aos comentários sobre a produção de José Cândido de Carvalho, que aparecem geralmente ofuscados pelas análises de obras de autores paradigmáticos do período, como Guimarães Rosa e Clarice Lispector. De modo geral, essa é a tendência das historiografias tradicionais, como se verifica nos seguintes livros: volumes V eVI da coleção A literatura no Brasil, organizada por Afrânio Coutinho (1997), História concisa da literatura brasileira, de Alfredo Bosi (1974), História da literatura brasileira, de Nelson Werneck Sodré (1982) e o volume II de A literatura brasileira: origens e unidade (1500-1960), de José Aderaldo Castello (1999). A exceção encontra-se na publicação recentemente ampliada de História da literatura brasileira: da Carta de Caminha aos contemporâneos, de Carlos Nejar (2011), em decorrência da estrutura da obra, que conta com um texto ensaístico para cada autor. 
Na sequência, após discutir a posição do romance na historiografia literária, será o momento de apresentar e comentar algumas leituras críticas da obra. Trata-se dos estudos de José Hildebrando Dacanal (1970), Regina Zilberman (1977) e Zilá Bernd (1998). Esses trabalhos foram selecionados em vista da verticalidade que demonstram em relação aos eixos de investigação aqui propostos, a saber, a possível inscrição do romance na tradição regionalista da literatura brasileira e a presença do insólito na narrativa. Desse modo, partindo dos resultados já alcançados, mas também os ampliando com a problematização dessas perspectivas e com a observação de questões ainda em suspenso tanto pela crítica quanto pela historiografia literárias, será proposto um novo caminho de leitura para o romance de José Cândido de Carvalho.

\section{O lugar de $O$ coronel e o lobisomem segundo a historiografia literária}

No quinto e penúltimo volume de A literatura no Brasil, Ivo Barbieri (1997) assina o texto "Situação e perspectivas", que constitui o sexto tópico do capítulo "O modernismo na ficção". Nesse texto, o crítico realiza uma breve apresentação de vários ficcionistas das décadas de 1950 e 1960. José Cândido de Carvalho é o primeiro escritor abordado, ao que seguem os nomes de Herberto Sales, Mário Palmério, Bernardo Élis, entre outros autores. Saliente-se que as apresentações das obras de Guimarães Rosa e Clarice Lispector aparecem juntas na distribuição do livro, no tópico "Instrumentalismo", exatamente anterior ao de Barbieri, e essas análises - extensas - são assinadas, respectivamente, por Franklin de Oliveira e Luiz Costa Lima.

Ivo Barbieri (1997, p.560) inicia suas considerações identificando a existência de três "núcleos aglutinadores" ou "linhagens" na ficção do referido período: o primeiro seria composto por romances documentários, de testemunho e crítica social; o segundo, por obras intimistas, voltadas aos "subterrâneos da consciência"; e o terceiro, por obras que trabalham com as possibilidades da língua, 
“experimentando novas técnicas e novos meios de expressão". Na sequência, situando José Cândido no primeiro grupo, o crítico afirma:

Por força da tradição literária, instaurada nos períodos romântico, realista, naturalista e intensificada no Modernismo, é sob o signo da representação de áreas regionalmente marcadas que se inscreve grande parte dos prosadores contemporâneos. É grande a família dos que se celebrizaram contando a saga rude dum Brasil primitivo, semibárbaro, feudal. Nesses, o romance e o conto fizeram-se veículo de análise e crítica social, a linguagem diversificou-se com o aproveitamento dos falares regionais, mas a arte de narrar guardou as marcas da tradição. Enquadram-se nessa tendência, entre outros, José Cândido de Carvalho, Herberto Sales e Mário Palmério. (Barbieri, 1997, p.560-1, grifo nosso)

Pelo excerto transcrito, verifica-se que o crítico toma José Cândido e os demais autores mencionados como continuadores de uma tradição literária que teria percorrido vários períodos estéticos, desde o Romantismo, e cuja base seria a "representação de áreas regionalmente marcadas". Essa "tradição literária”, não propriamente nominada pelo autor, parece corresponder, por sua caracterização, a uma concepção de regionalismo em sentido amplo, como uma tendência que se manifesta em diferentes momentos da literatura nacional, conforme propõe Araújo (2008, p.119): "Pode-se abordar a tradição regionalista como uma das dominantes construtivas do romance romântico brasileiro, da mesma forma que se pode recorrer a ela para compreender momentos decisivos da moderna literatura brasileira, de modo a promover releituras da permanência dessa tradição no sistema literário" . Retornando às considerações de Barbieri, o grupo de "prosadores contemporâneos", herdeiros dessa tradição literária "anônima”, apresentaria uma obra marcada pela crítica social, no plano ideológico, e pelo aproveitamento de falares regionais, no plano linguístico.

Sobre a obra de José Cândido, especificamente na imediata continuação do trecho citado, Barbieri (1997, p.561) afirma: "Olha 
para o céu, Frederico (1939) e O coronel e o lobisomem (1964) de José Cândido de Carvalho (1914) ilustram bem o epigonismo de 1930". Ora, essa homogeneização das obras não se sustenta, tanto em vista das diferenças - aqui apresentadas - existentes entre elas, quanto também das opiniões daqueles que visualizaram, no surgimento do livro de 1964, uma renovação do regionalismo, em específico (Queirós, 1983), ou uma nova dimensão ao romance brasileiro, em geral (Martins, 1970). Assim, o crítico, ao inscrever José Cândido de Carvalho entre os autores das décadas de 1950 e 1960, promove a indistinção entre seus dois romances, anulando suas peculiaridades e associando, ambos, ao período de 1930. O que se verifica, portanto, é a tentativa de aproximar as obras do autor, desconsiderando a distância temporal que as separa e, principalmente, homogeneizando-as em seus traços constitutivos como se ambas correspondessem a uma mesma faceta da prosa de cunho regional.

Embora a associação, feita por Barbieri, entre o primeiro romance de José Cândido e o regionalismo dos anos 1930 seja oportuna e mesmo elucidativa para a compreensão de aspectos temáticos e formais da configuração da obra, conforme já demonstrou Luís Bueno (2006), o mesmo não se pode afirmar quanto à vinculação que faz do romance de 1964 a esse momento da prosa ficcional que lhe antecede em pelo menos três décadas. Se mesmo em Olha para o céu, Frederico!, obra derradeira dos anos 1930, pode-se reconhecer, por seu tom às vezes irônico e humorístico, certo distanciamento da seriedade das obras regionalistas mais representativas da década - o que permitiria pensar em um investimento do autor na diferenciação de seu trabalho -, em O coronel e o lobisomem, romance encarado como renovador da tendência, essa distância, que não é apenas temporal, acentua-se; entre outras razões, como se constatou, pela adesão de um novo paradigma de representação, não mais pautado na inclinação mimético-realista característica da prosa dos anos 1930.

Interessante nesse ponto é notar que tal perspectiva de Barbieri, a respeito da prosa de José Cândido, se contrapõe à apresentada no sexto volume dessa mesma coleção que, dirigida por Afrânio Coutinho, reúne textos de diferentes autores. Diante disso, faz-se agora 
uma breve digressão antes de se retornar às considerações de Ivo Barbieri. Nesse sexto volume da coleção, o crítico e ficcionista Assis Brasil (1997) assina o capítulo "A nova literatura brasileira”, um dos que compõem a conclusão da obra. Nesse capítulo, ao tratar do romance brasileiro posterior ao ano de 1956, o crítico menciona um grande número de escritores. José Cândido de Carvalho é o segundo deles, aparecendo logo depois de Herberto Sales, a quem o autor o compara. Na perspectiva de Assis Brasil (1997, p.248), "Deve-se desligar Herberto Sales do chamado Romance do Nordeste [...]. Ligado por certas contingências ao que os críticos chamam de 'regionalismo', os romances de Herberto Sales, no entanto, podem ser apreciados sem esta visão estrábica e limitada da década de 30". Para justificar essa opinião, o crítico afirma que, embora Sales apresente as "constantes da escola”, já não seria possível situá-lo entre os romancistas de 1930 despreocupados com o plano da forma, "da criação", e voltados apenas a suas "cogitações parassociais ou paraideológicas" - ressalva feita apenas a Graciliano Ramos. Na continuação, Assis Brasil apresenta José Cândido sob esse mesmo juízo:

Neste mesmo plano de concepção, vale a pena citar José Cândido de Carvalho: O coronel e o lobisomem (1964) - a rica experiência de linguagem, "o retrato do Brasil" interiorano, sem aproximações a escolas ou preconceitos literários. O interesse de renovação da prosa de José Cândido de Carvalho o credencia a prosseguir com os novos, em busca de maior projeção do romance brasileiro. (Brasil, 1997, p.248, grifos nossos)

Desse modo, pela comparação dos dois únicos momentos em que José Cândido de Carvalho é mencionado na coleção, percebe-se que se falou pouco sobre o autor e, mesmo assim, com pouco acordo entre as visões: enquanto Ivo Barbieri equipara ambos os romances do escritor dizendo que "ilustram bem o epigonismo de 30”, Assis Brasil, aproximando-o da prosa de Herberto Sales, rejeita qualquer vinculação de seu romance de 1964 "a escolas ou preconceitos literários”, ou seja, ao regionalismo de 1930. Embora Assis 
Brasil desassocie O coronel e o lobisomem dessa tendência que, como o próprio crítico afirma na avaliação de Sales, estaria voltada às preocupações "parassociais ou paraideológicas", reconhece no romance carvalhiano - ainda que entre aspas - "“o retrato do Brasil' interiorano”. A ideia de "escola ou preconceito”, mencionada pelo crítico, pode explicar muito dessa postura da crítica em resistir à utilização do termo regionalismo, ainda que para isso suas avaliações beirem à contradição. Logo, constata-se um impasse na opinião desses críticos quando comparados entre si e, no caso do último, o problema se anuncia mesmo internamente a suas ponderações.

De volta aos comentários de Ivo Barbieri (1997), o crítico aproxima, então, a prosa de $O$ coronel e o lobisomem dos seguintes autores: de José Lins do Rego, pela semelhança da caracterização do coronel Ponciano em relação ao capitão Vitorino, de Fogo Morto; de Graciliano Ramos, pela "força do estilo", e de Guimarães Rosa, de cuja prosa o campista captaria "ressonâncias", "sem contudo se aproximar da ousadia inventiva e arquitetônica de Grande sertão: veredas". E, para finalizar o único e longo parágrafo em que tratou dos dois romances do autor - além de outros prosadores -, Barbieri assevera:

O coronel e o lobisomem padece de sensível desequilíbrio estrutural. De início, o autor liga episodicamente os capítulos, tecidos com as valentias de que o personagem narrador "tem honra e faz alarde". Da metade para a frente, encaminha organicamente a narrativa, mas sem o mesmo interesse dos episódios iniciais. Em consequência desta quebra, o Coronel Ponciano, que se heroicizara pela própria loquacidade, apequena-se e se esvai. (Barbieri, 1997, p.561)

Observe-se a linha de raciocínio: o "desequilíbrio estrutural" de que padece a obra, na visão do crítico, estaria no fato de a narrativa começar com os feitos heroicos de Ponciano e se encaminhar "organicamente" (o que só paradoxalmente resultaria ainda em uma "quebra") à perda do interesse por esses mesmos episódios iniciais. $\mathrm{O}$ grave problema estrutural de que sofre o romance consistiria, assim, na "des-heroicização" de Ponciano, que "apequena-se e se esvai". 
Aos que conhecem o romance, não parece necessário explicar o grande equívoco dessa leitura, mas, por ser um texto que compõe uma obra de referência à historiografia literária brasileira e, certamente, um dos primeiros a que um leitor em formação poderia recorrer para buscar maiores informações e formar um juízo sobre a produção de José Cândido, mostra-se oportuno desfazer qualquer ambiguidade.

Aquilo que essa leitura aponta como razão para um suposto desequilíbrio estrutural do romance $O$ coronel e o lobisomem consiste, justamente, na explicação de um de seus maiores méritos composicionais: a crescente tensão da narrativa, decorrente da degradação de um herói, cujo drama frente à ameaça representada pelo mundo alcança tal tragicidade que sequer pode ser resolvido no plano da realidade, exigindo, assim, da obra, uma saída formal só encontrada em uma dimensão, por assim dizer, mágica. A diminuição gradativa da força do herói consolida-se, de fato, mais claramente a partir da metade da narrativa que, não por acaso, é quando Ponciano começa a fixar-se no ambiente urbano, deparando-se cada vez mais com sua impotência e desajuste frente aos valores de um novo tempo.

Logo, o que o crítico compreende como um momento de "quebra" da continuidade dos feitos heroicos da personagem corresponde exatamente ao momento em que o declínio de Ponciano torna-se mais evidente. A tensão instaurada na narrativa é levada ao ápice em seu final e o protagonista, apenas em outro plano que não o da vida e da realidade comum, volta a ser - ou, mesmo, passa a ser - um herói grandioso e destemido, com coragem suficiente para se dispor a enfrentar o responsável por todo o sofrimento do mundo. Para ir um pouco além, sem, contudo, pretender antecipar a análise da questão, pode-se dizer que o fenômeno compreendido pelo crítico como uma falha estrutural da narrativa poderia inclusive ser válido para associá-lo, considerando-se um esquema proposto por Alfredo Bosi (1974, p.440), aos "romances de tensão transfigurada", nos quais o conflito entre o herói e o mundo só alcançam solução pela "transmutação mítica ou metafísica da realidade".

Embora essa associação mostre-se possível em vista da composição do romance de José Cândido, Bosi ilustra esse grupo apenas com 
as obras de Guimarães Rosa e Clarice Lispector, definidas como as "experiências mais radicais" do gênero. A menção a José Cândido de Carvalho, em História concisa da literatura brasileira, se realiza no mesmo capítulo geral em que se faz essa reflexão, mais precisamente no subtítulo "Permanência e transformação do regionalismo". Nessa parte, depois de arrolar inúmeras obras lançadas entre princípio da década de 1930 e final da década de 1960, relacionadas de algum modo à "corrente da "literatura social”", é no último parágrafo que se encontra o comentário sobre o romance $O$ coronel e o lobisomem. Frise-se que, nesse tópico, enquanto o crítico apenas menciona e pouco comenta as obras de outros ficcionistas (trata-se de uma história concisa, como já explica o título), o romance de José Cândido é o único ao qual concede um parágrafo todo - e, justamente, o que antecede o tópico destinado a Guimarães Rosa:

Menção à parte merece José Cândido de Carvalho que conseguiu, em O Coronel e o Lobisomem (1964), captar os conflitos e os anseios de um homem de mente rústica sem cair na cilada que espreita as tentativas desse gênero, isto é, sem enrijecer a sua personagem no puro tipo, o que, aliás, lhe seria fácil realizar com brilho, dados os pendores do ficcionista para explorar o ridículo das suas criaturas. Releva ainda notar a justeza expressiva da sua linguagem verdadeiramente clássica sem deixar de ser moderna. (Bosi, 1974, p.481)

O crítico, portanto, chama a atenção para a linguagem do romance, clássica e moderna a um só tempo, e para a capacidade do autor em captar os conflitos de "um homem de mente rústica", sem, com isso, torná-lo um tipo, ou seja, uma personagem desprovida de profundidade psicológica. O relevo à dimensão psicológica da personagem e à importância do conflito do herói com seu meio também aparecem na única outra referência que Bosi faz a José Cândido - ao falar do enfraquecimento do "veio neorrealista da prosa regional" e da permanência de uma ficção intimista, a partir dos anos 1950: 
Escritores de invulgar penetração psicológica, como Lígia Fagundes Telles, Antônio Olavo Pereira, Aníbal Machado, José Cândido de Carvalho, Fernando Sabino, Josué Montelo, Dalton Trevisan, Autran Dourado, Otto Lara Resende, Adonias Filho, Ricardo Ramos, Carlos Heitor Cony e Dionélio Machado têm escavado os conflitos do homem em sociedade, cobrindo com seus contos e romances de personagem a gama de sentimentos que a vida moderna suscita no âmago da pessoa. E o fluxo psíquico tem sido trabalhado em termos de pesquisa no universo da linguagem na prosa realmente nova de Clarice Lispector, Maria Alice Barroso, Geraldo Ferraz, Lousada Filho e Osman Lins, que percorrem o caminho da experiência formal. (Bosi, 1974, p.435, grifos nossos)

Por sua vez, Nelson Werneck Sodré, o historiador, comunista, militar e crítico literário, a quem José Cândido dedicaria $O$ coronel e o lobisomem, faz apenas uma única e breve menção ao romance do autor em seu livro História da literatura brasileira. Das três grandes partes em que essa obra se divide ("Literatura colonial", "Esboço da literatura nacional" e "Literatura nacional"), a referência a José Cândido aparece nesta última, especificamente no tópico "A crise formalista", que vem depois de "Modernismo". Sodré apenas situa José Cândido em um quadro amplo e variado de autores da literatura da época, escolhidos, aparentemente, de modo um tanto aleatório:

[...] Nessa fase [década de 1930], ainda, começam a aparecer autores novos, como Oswaldo Alves; Orígenes Lessa, que passa do jornalismo à ficção, contista e novelista que retrata gente do povo; J. J. Veiga, dono de obra singular em nossas letras; Mário Palmério, que liberta o regionalismo do pitoresco e fixa os costumes provincianos; W. Autran Dourado, escritor seguro de seu mister, dono de uma prosa límpida e adequada à pintura das emoções; Bernardo Ellis, regionalista sem os cacoetes típicos do gênero; Dalton Trevisan, que encabeça extensa lista dos modernos e excelentes contistas brasileiros. Nessa menção a autores e obras tão diversas - entre elas, caberia referir a criação original de José Cândido de Carvalho, $O$ coronel e o 
lobisomem (1964) - fica evidenciada a amplitude atingida pela moderna ficção brasileira. (Sodré, 1982, p.599)

Sobre o romance de José Cândido, a única constatação, portanto, é a de que se trata de uma "criação original". O silêncio do crítico pode se dever a várias razões, como a amizade com o autor ou a brevidade geral dos demais comentários. O trecho citado deixa margem para algumas suposições. Nesse sentido, note-se que, quando o crítico comenta as obras de Mário Palmério e Bernardo Élis, fica a impressão de haver uma indecisão em seu julgamento, como se desejasse apontar a faceta regionalista dos autores e, ao mesmo tempo, negá-la, como se, na mesma perspectiva de Assis Brasil, fosse característica condenável ou empobrecedora às produções: "[...] que libera o regionalismo do pitoresco e fixa os costumes provincianos" - a associação dessas ideias soa até contraditória; "[...] regionalista, sem os cacoetes típicos do gênero" - ou seja, regionalista, mas, sem ser regionalista. Por esse raciocínio - talvez incondizente com as reais motivações do crítico, mas, pelo menos, coerente em sua base pelo próprio texto do autor -, pode-se supor que a falta de maiores detalhes sobre o romance de José Cândido decorra dessa dificuldade para compreender, definir ou mesmo aceitar essa fase da literatura nacional que, ainda fecunda (para o embaraço da crítica), busca seu material e essência no aproveitamento da temática rural, mas por novos meios de expressão.

O estudioso José Aderaldo Castello, em A literatura brasileira: origens e unidade (1500-1960), também procura situar o romance de José Cândido de Carvalho. O esquema de periodização da obra como um todo se distribui em três grandes momentos: Período Colonial (compreendendo os estilos de época do Quintentismo ao Pré-Romantismo), Período Nacional-I (do Romantismo ao Simbolismo), compondo ambos o volume I, e Período Nacional-II (Pré-Modernismo e Modernismo, até a década de 1960), correspondendo ao volume II. As referências a José Cândido encontram-se, portanto, neste último volume, que compreende em sua totalidade apenas as produções do século XX. José Cândido consta do capítulo 
XXII da obra, intitulado "Produção literária do Modernismo - plenitude e transformação: $2^{\circ}$ ) A prosa de ficção - 2. Novas contribuições". Depois de tratar dos "Romancistas do Nordeste" no capítulo anterior (José Américo de Almeida, Rachel de Queiroz, Jorge Amado, José Lins do Rego e Graciliano Ramos), o crítico aborda, em "Novas contribuições", os autores que surgem no panorama ficcional entre as décadas de 1930 e 1940: Ciro dos Anjos, Cornélio Pena, Otávio de Faria, Érico Veríssimo, Vianna Moog, José Vieira, José Cândido de Carvalho, Marques Rebelo, José Geraldo Vieira, Dionélio Machado, Lúcio Cardoso, Clarice Lispector e Guimarães Rosa. Segundo Castello (1999, v.2, p.323), entre esses escritores haveria "alguns presos a posições regionalistas, outros independentes e inovadores, mas todos continuadores de nossa ficção modernista".

O romance de José Cândido é apresentado, mais uma vez, pouco antes da análise da obra de Guimarães Rosa, autor contemplado com um tópico isolado em vista do método adotado por Castello, que consiste em destacar, em cada um dos capítulos, uma obra ou escritor paradigmático do período. Como o critério utilizado pelo historiador baseia-se na disposição cronológica dos autores tendo por referência o ano de sua estreia literária, José Cândido, cuja primeira publicação reconhecida se deu em 1939, aparece entre o grupo dos autores que surgem durante as décadas de 1930 e 1940 e acaba não sendo retomado quando o crítico aborda as obras de 1960. Se isso, por um lado, não implica, de modo algum, no descrédito do conjunto dessa historiografia de Castello - a qual, inclusive, recorrer-se-á adiante para embasar a discussão sobre o regionalismo - por outro, expõe a certa assincronia a posição de algumas obras. No caso de José Cândido, inscrito entre autores da década de 1930 e 1940 pelo lançamento de Olha para o céu, Frederico!, é pelo romance O coronel e o lobisomem, lançado apenas vinte e cinco anos depois, que o autor terá sua contribuição avaliada por Castello e posta em relação a outros títulos. Está claro que isso não impede o crítico de habilmente efetuar antecipações e recuos para estabelecer paralelos e associações. Mas, principalmente, pela recorrência do fato em outras obras, reconhece-se uma tendência da historiografia literária em situar $O$ coronel e 
o lobisomem, romance de 1964, antes da prosa de Guimarães Rosa, cuja estreia no conto se deu em 1946, com Sagarana, e no romance, em 1956, com Grande sertão: veredas. Ou seja, com isso, o romance de José Cândido é retirado de seu contexto (meados de 1960), posterior ao aparecimento da prosa revolucionária de Guimarães Rosa, para ser apresentado antes dela. Aderaldo Castello (1999, v.2, p.334) situa José Cândido entre os autores da década de 1930 e 1940 - o que é pertinente tendo em vista seu critério de seleção -, apesar de referir-se ao livro $O$ coronel e o lobisomem para comentar a atuação do autor, mencionando o romance de 1939, Olha para o céu, Frederico!, apenas em nota de rodapé. Os comentários sobre o livro de 1964 apresentam-se em um único parágrafo, no qual se apontam vários diálogos com a tradição suscitados pela obra:

[...] E ainda José Vieira e José Cândido de Carvalho, autores respectivamente de Vida e Aventura de Pedro Malazarte e O coronel e o lobisomem, que exemplificam entre nós reflexos do picaresco, com o exagero e a fantasia do narrado, gerando a mentira fabulosa. Contamos, neste sentido, com uma significativa sequência de narrativas, seus heróis e anti-heróis: Casos de Romualdo, de Simões Lopes Neto, irmão de Histórias de Alexandre, de Graciliano Ramos, Macunaíma ao qual se prende, pelo veio da literatura popular em verso, a Vida e Aventura de Pedro Malazarte. Com todos eles se relacionam $O$ Coronel e o Lobisomem e algumas criações de Jorge Amado, destacadamente A morte e a Morte de Quincas Berro D’Água. [...] E, com exceção desta novela de Jorge Amado, a qual compõe com Gabriela, Cravo e Canela dois exemplos de destaque, os demais citados surgem como projeções da imaginativa recriadora da cultura tradicional - contos, cantos, mitos retransmitidos pela oralidade, uns originais nossos, outros incorporados e assimilados. Em todas elas, por sua vez, a linguagem se faz inconfundível e adequada, conforme já se observou a propósito de $O$ Coronel e o Lobisomem e, caso à parte, Grande Sertão: Veredas, personificando mesmo seus personagens-heróis, autonarradores. Talvez o traço em comum seja a oralidade, ao mesmo tempo distinto de um para 
o outro e graças sobretudo ao ritmo. Regionalismo? Sim, enquanto compromisso com a cultura popular brasileira, suas tradições retransmitidas oralmente, sem prejuízo, contudo, da universalidade do legado assimilado. (Castello, 1999, v.2, p.334-5)

Demonstrando conhecimento da crítica anterior ao retomar explicitamente considerações de Manuel Cavalcanti Proença (1970), José Aderaldo Castello (1999, v.2, p.334) inicia sua apreciação afirmando haver no romance de José Cândido "reflexos do picaresco, com o exagero e a fantasia do narrado, gerando a mentira fabulosa" e, a partir disso, menciona algumas obras que também comporiam essa tradição. Esse ponto é significativo por problematizar a hipótese, que se está aqui averiguando, sobre os elementos que contribuem para a dimensão insólita do romance. Se os episódios extraordinários (no sentido de estarem para além do comum) corresponderem apenas a mentiras contadas por Ponciano, o "invencioneiro e linguarudo" (Carvalho, 1983, p.3), isso poderia desestabilizar a hipótese rastreada sobre a existência de uma esfera insólita no romance? Considerando-se o final da narrativa, conforme demonstrado, pode-se antecipar que não: ainda que se aceite que as histórias de Ponciano apresentam-se como mentiras forjadas no interior de seu discurso, e ele, portanto, corresponda a um contador de histórias como o era na crônica, isso não abalaria a essência de irrealidade que persiste na estrutura macro da obra, dada a condição sobrenatural do narrador enquanto "defunto autor". Esse problema será retomado adiante, uma vez que esta é uma resposta apenas parcial à questão que, para ser elucidada, demanda uma análise instrumentalizada da obra sob tal perspectiva.

Sondando a continuação do raciocínio de Aderaldo Castello (1999, v.2, p.335), O coronel e o lobisomem e as demais obras destacadas (com exceção dos livros citados de Jorge Amado) seriam "projeções da imaginativa recriadora da cultura tradicional", relacionada a criações populares de transmissão oral, como contos e mitos, oriundos tanto do repertório nacional quanto do estrangeiro assimilado. Isto, no caso do romance em questão, pode-se entender 
que corresponda à incorporação de elementos do universo folclórico e das crendices populares, presentes nas figuras híbridas do lobisomem, da sereia e do ururau.

O crítico destaca ainda, aproximando José Cândido a Guimarães Rosa, a importância da linguagem "inconfundível e adequada" do romance, que tem a capacidade de, como também ocorre em Grande sertão: veredas, "personificar" o herói autonarrador. Nesse ponto, procurando explicar (utiliza um "talvez") o denominador comum existente entre os autores, o crítico aponta, simplesmente, para a possibilidade de ser a "oralidade" de ambos, ainda que reconheça diferenças em relação ao "ritmo" de cada um. E, para finalizar, como que não convencido da aproximação justificada unicamente pelo critério da linguagem - ainda mais quando se está tratando de um período todo herdeiro da liberdade linguística conquistada pelos modernistas dos anos 1920, que incorporaram à linguagem literária os mais diversos falares e coloquialismos oriundos da "oralidade" -, o crítico encontra o que sinteticamente pode definir a correlação entre os autores, repita-se, tão próximos e tão singulares a um só tempo: "Regionalismo? Sim, enquanto compromisso com a cultura popular brasileira, suas tradições retransmitidas oralmente, sem prejuízo, contudo, da universalidade do legado assimilado" (Castello, 1999, v.2, p.335, grifo nosso). Portanto, o estudioso admite a existência de uma filiação comum a essas obras das décadas de 1950 e 1960, a que chama regionalismo - denominação a que outros críticos se esquivam por meio de circunlóquios. ${ }^{1}$

Finalmente, entre os autores das historiografias literárias mencionadas, Carlos Nejar (2011) versa sobre o romance de José Cândido de Carvalho em História da literatura brasileira: da Carta de Caminha aos contemporâneos. Nejar, que além de crítico é poeta premiado e de vasta produção, opta por um modo bastante particular para apresentar suas considerações sobre José Cândido e os demais autores que analisa, pois se utiliza de uma linguagem poética, por

1 As implicações do termo na historiografia e crítica literárias brasileiras serão discutidas no Capítulo 3. 
vezes ambígua, e de um formato ensaístico despreocupado com o periodismo literário. Desse modo, a organização e o projeto do livro diferenciam-se essencialmente do teor dos outros estudos aqui apresentados. ${ }^{2} \mathrm{O}$ ensaio sobre José Cândido (o livro possui um tópico para cada autor, pois o intuito é valorizar as peculiaridades individuais) intitula-se "O coronel e o lobisomem e outras histórias do picaresco e assombrado de José Cândido de Carvalho" e apresenta-se no capítulo "Os mágicos da ficção". Assim, o nome de José Cândido aparece ao lado de autores que cultivaram o insólito ficcional: Murilo Rubião, Campos de Carvalho, Lygia Fagundes Telles, Dalton Trevisan, Samuel Rawet, Ricardo Ramos, Autran Dourado, José J. Veiga, Hilda Hilst, Moacir C. Lopes e Hélio Pólvora. Guimarães Rosa que, nas outras historiografias vinha acompanhando (geralmente sucedendo) José Cândido, aparece agora em momento bastante anterior e junto apenas de Clarice Lispector, no capítulo "Poética do romance contemporâneo". A diferente disposição e categorização desses autores sugere por si só um pouco do modo peculiar como o crítico compreende a dinâmica entre as obras.

Carlos Nejar inicia seu ensaio apresentando dados sobre a vida e obra de José Cândido. ${ }^{3} \mathrm{Na}$ sequência, compara o romance de

2 Em entrevista, Carlos Nejar (2011) explica a proposta diferenciada de seu livro: "A vinculação da literatura a uma visão puramente social tem empobrecido certa crítica, entre nós, pois a obra que não se realiza esteticamente, através da linguagem, pode valer como panfleto, testemunho, jamais como arte. Não permanecerá. O social entrará pela porta dos fundos ou pela despensa, não na entrada da casa. Daí a distinção que marca a minha História: não são os gêneros que determinam a linguagem, é a linguagem que determinará os gêneros. Feito esse introito, por mais problemática que seja a questão do talento individual ou do gênio na perspectiva histórica tradicional, é impossível não reconhecê-los". É oportuno esclarecer que as outras historiografias literárias comentadas seguem uma metodologia explicitamente díspar desta de Nejar, pois buscam compreender a formalização estética das obras tendo em vista as conjunturas históricas, sociais e culturais do país.

3 Verificam-se algumas incorreções quanto às datas apontadas por Carlos Nejar (2011, p.780) em relação a José Cândido, mesmo na edição revista da obra. Foram localizadas as seguintes ocorrências: o falecimento do autor ocorre em $1^{\circ}$ de agosto de 1989, não no dia 10 desse mês; o lançamento de Olha para o céu, 
1939 com o de 1964 para afirmar a superioridade deste. A partir disso, focalizando-se em $O$ coronel e o lobisomem, o crítico destaca a figura do coronel Ponciano, comparando-o a outros personagens da literatura brasileira, a saber, Riobaldo, Fabiano, capitão Rodrigo Cambará e Vitorino Carneiro da Cunha. Ao chamar a atenção para a linguagem do romance, Nejar afirma (2011, p.781): "Sem lembrar ninguém, sem transitar pelo enveredar rosiano, contemporâneo de si mesmo, reproduziu a estilizada, astuta e viandante fala do povo". A dissociação entre a linguagem dos dois autores acaba, de qualquer modo, por relacioná-los, evidenciando que, embora o crítico não os considere parecidos estilisticamente, isto se apresenta como uma leitura frequente da obra, pois, do contrário, seria desnecessário afirmar-lhes as diferenças. Distinguindo-os, ainda, o crítico (p.783) acrescenta que José Cândido não utiliza "os valores simbólicos" como Guimarães Rosa e "nem inventa palavras, nem é demiurgo e cosmológico. E seu alicerce é irracional, como a representação de todo um mundo velho que desaba". Apesar de afastá-los quanto à linguagem, Nejar (p.783) apontaria, depois, traços da prosa do campista que também costumam ser ditos sobre a do mineiro - "a riqueza do idioma que se revitaliza de achados, entre arcaísmos, ditos populares [...]", mas na continuação atribui essa linguagem à "malandragem do carioca", como que para desviar a aproximação que o comentário poderia suscitar.

A partir daí, o crítico toca em um dos aspectos presentes no título do ensaio: o elemento picaresco, que reconhece tanto na personagem, quanto em seu criador. Sobre este, afirma: "[José Cândido] como todo picaresco, ri-se dos poderosos, ou até da transitoriedade humana". E, quanto à personagem, retomando a figura de Ponciano, compara-o "ao herói pícaro, com mecanismo de parodização subjacente e ao mesmo tempo de valentia, certa imponente arrogância senhorial - peculiar aos coronéis" (p.783). Além de reconhecer em Ponciano o herói pícaro, associa-o também ao herói quixotesco e,

Frederico! data de 1939, não de 1938 e, desse modo, não são 26 anos, conforme afirma, mas $\operatorname{sim} 25$ que a separam de O coronel e o lobisomem (1964). 
para tanto, compara-o novamente a Vitorino: enquanto este seria o herói quixotesco inclinado ao ridículo, Ponciano corresponderia ao quixotesco que raia ao humor, com "gumes de sátira cortante e peculiaridades épicas” (p.783). A inclinação ao modelo de Cervantes, pode-se entender, corresponderia ao idealismo de Ponciano, enquanto as "peculiaridades épicas" dizem respeito à grandiosidade e à tragicidade de que se falou sobre a personagem.

O outro elemento mencionado no título do texto, o assombrado-caro a essa reflexão por justificar a inclusão do autor entre "Os mágicos da ficção" -, aparece no ensaio de Nejar em tom ainda mais poético, momento menos empenhado em explicar a dimensão mágica do romance e mais em sugerir-lhe abordagens e diálogos com os cânones do fantástico da literatura ocidental. Essa parte da discussão se inicia com as seguintes afirmações: "O sobrenatural se rivaliza com o cotidiano, o teor do fantástico conduz à fábula” (p.783). Com efeito, as ideias de conflito ou de convivência harmônica entre o sobrenatural e o cotidiano procuram servir de base para as discussões propostas pelas teorias voltadas ao estudo do "fantástico", em suas diversas vertentes. Na perspectiva do autor, portanto, o sobrenatural no romance "rivaliza", ou seja, disputa, concorre, com o cotidiano, de modo a conduzir à fábula, termo que pode ter sido usado em alguma das seguintes acepções: fábula enquanto "narração de aventuras e de fatos (imaginários ou não)" ou, simplesmente, "fato inventado; invencionice" (Houaiss, 2009).

Esses sentidos se confirmam na continuação do texto, com a alusão às "imagens de faiscantes lances" que o romance suscitaria na imaginação do leitor. Corroborando a ideia de que José Cândido, picaresco, ri-se dos poderosos, Nejar faz referência às personagens caricaturais que se pretendem "eminências", mas que na verdade não o são. E afirma que todo esse mundo "[...] começa e termina na infância. Por ser linguagem”. Em outros termos, o crítico (e agora também poeta) aproxima o mundo ficcional carvalhiano, em sua criação verbal, ao universo da infância, por ser o período da vida em que a imaginação é mais aflorada. Em suma: tudo é criação, invenção, inclusive a linguagem da obra: "A infatigada invenção, desinventando 
o idioma, virando de pernas ao ar e sempre exatíssimo, conduz a etapas da imaginação imprevistas" (Nejar, 2011, p.784). Reiterando a afirmação de que José Cândido seria um "inventor de linguagem”, o crítico (p.781) poeticamente sugere a atuação da invenção sobre o idioma que, portanto, é reinventado, mas ainda assim, apesar das modificações, conserva-se "exatíssimo". Nesse ponto, Nejar está corroborando uma percepção de Rachel de Queiroz, citada no início de seu ensaio, segundo a qual as palavras de José Cândido no romance, se ainda não existiam, estavam fazendo falta, ou seja, eram precisas e justas, "exatíssimas" em seu sentido. Diante de toda essa ênfase na criação linguística do autor, soa contraditório o trecho em que o próprio Nejar afirma que José Cândido era diferente de Rosa porque "nem inventa palavras" (p.783).

De qualquer modo, o crítico continua a enfatizar a importância da invenção no romance, agora também em relação ao protagonista, de modo que a imaginação geraria um "polo hipnótico" que vai da linguagem ao protagonista e vice-versa. E, para encerrar, propõe:

Porque não há linguagem que não ensine a enganar, ou caia em sua própria armadilha, ou carisma. Ainda que na picardia, a criação de José Cândido confirma a frase de Plotino: "o desejo de ver provoca a visão". E a visão provoca a fantasmagoria. [...] Dostoievski afirma que todos saímos debaixo do capote de Gogol. Ampliando esse conceito, o coronel Ponciano e José Cândido saíram debaixo do nariz de Gogol. No lado engraçado, com tomadas de nonsense, cinético e aventureiro, bárbaro e prepotente, às vezes inofensivo, outras, grotesco, como a classe social decadente que representa. [...] Tudo gira em torno de Ponciano, e ele é o mundo. O lobisomem, como o Mefistófeles de Goethe, nasceu para ser vencido. O resto o completa. $\mathrm{Ou}$ nele se confunde. (p.783-4, grifo nosso)

No trecho destacado, a menção à capacidade da linguagem de "ensinar a enganar" e, ao mesmo tempo, tornar-se uma "armadilha" que logra quem a enuncia refere-se à figura de Ponciano, como se ele, de tanto mentir, passasse a crer nas ilusões criadas. E, de fato, essa é a 
tônica de muitas passagens da vida cotidiana do herói que, desejando se mostrar valente e inabalável, acaba por se tornar cômico, traído pelo próprio discurso na tentativa de convencer o leitor, resultado do distanciamento entre o narrador e a voz do autor implícito. Com a frase de Plotino, Nejar sugere que Ponciano, de tanto desejar "ver", via. Ou seja, está se insinuando que a dimensão mágica do romance não passa de uma criação mental de Ponciano, um universo que lhe é particular. Logo após evocar o fantástico que marca a literatura de Gógol, o crítico-poeta ainda remete à "classe social decadente" que o protagonista representa. Com isso, se as análises das dimensões insólita e social do romance, na leitura de Nejar, não chegam a se conjugar, ao menos também não se excluem. E, no encerramento, estabelecendo diálogo também com a obra de Goethe, o autor sugere que Ponciano, centro de tudo no romance, assim como Fausto, inconformado com suas limitações, precisou buscar na magia o fim de suas incertezas, mas, com isso, precisaria também derrotar sua traidora criação, o lobisomem (ou o diabo, a representação do mal, no fim da narrativa), tal como o protagonista da peça alemã precisaria vencer Mefistófeles e a maldição a que estava condenado.

Vários pontos da argumentação de Carlos Nejar buscam embasar-se, ainda que não declaradamente, como o faz José Aderaldo Castello, nas reflexões de Manoel Cavalcanti Proença (1970), autor do ensaio "Romance definitivo". Além desse texto, alguns comentários de Nejar deixam ver ainda ecos da análise de Wilson Martins (1970) em "Uma obra-prima". Ambos os ensaios merecem ser mencionados ao lado de obras de referência da historiografia literária pela relevância que ganharam, como se vê, enquanto norteadores da crítica e do público, ao se apresentarem como paratextos do romance O coronel e o lobisomem, a partir da $3^{\text {a }}$ edição da obra, quando, então editada pela José Olympio, alcançaria o posto de best-seller.

Nesse sentido, muitos dos intertextos apontados por Aderaldo Castello e Carlos Nejar, entre a obra de José Cândido e a de outros autores da literatura nacional, já se encontravam no ensaio de Cavalcanti Proença. É desse crítico também o reconhecimento da filiação picaresca explorada por ambos os historiadores. Cavalcanti Proença 
(1970, p.xii) insere Ponciano numa linhagem de personagens que resgatam a figura do contador de histórias: "Filiação aos criadores de cidades míticas [...] filiação aos 'queima-campo', caboclos imaginosos da linha de Barão de Munchhausen”. A relação com este último, protagonista do livro de Rudolf Erich Raspe (2011), é enfatizada pelo crítico pelos "tantos outros casos [de Ponciano], secos e crespos, difíceis de engolir, a não ser meio tonteado com a fala narrativa do Coronel" (Proença, 1970, p.xiii). As aventuras do Barão de Munchausen são as histórias mirabolantes de um ex-combatente de guerra junto ao exército russo que, na velhice, passa a contar seus feitos inverossímeis, mas envolventes. Pela narração em primeira pessoa, são descritas, numa ambientação rural, lutas com animais ferozes, episódios de caças impossíveis, aparições de seres mágicos etc. Com isso, Proença está afirmando, apoiado pelas vozes de Castello e Nejar, que o universo insólito de Ponciano constitui-se de invenções do narrador, e não de uma "realidade" mágica construída como possível no interior da narrativa.

Como a figura do contador de histórias encontra também espaço na literatura ligada ao meio rural brasileiro, Proença não tarda em reconhecer o vínculo e afirmar a importância da literatura regional como base e precursora da literatura brasileira. Aponta também, nesse sentido, a vinculação de Ponciano com Riobaldo, afirmando a equiparação do mérito das obras de ambos. O fator social é outro elemento, destacado pelo autor, que também pode ser compreendido na esteira da tradição da literatura regionalista: "[Ponciano] é um tipo decadente; não em pessoa, mas porque representa uma estrutura agrária sem saída na sua organização social arcaica" (Proença, 1970, p.xv).

O ensaio de Wilson Martins (1970), por sua vez, publicado primeiramente em jornal (1964, p.2) logo após a estreia do romance, aproxima-se da leitura de Proença em alguns pontos, mas dela se afasta em outros. Quanto à relação da obra com a tradição da literatura regionalista, diferentemente de Proença, que aceita a vinculação, Martins mostra-se resistente e intransigente aos romances de inclinação social dos anos 1930, aliás, motivo da crítica mordaz que 
desfere ao livro de estreia de José Cândido. Mesmo reconhecendo a "influência inegável de Grande sertão: veredas", em $O$ coronel e o lobisomem, o crítico afirma:

No fundo, O coronel e o lobisomem é um romance urbano, ou, pelo menos, civil (no sentido etimológico da palavra), romance psicológico como o de Guimarães Rosa é metafísico, os recursos propriamente de estilo sendo, em ambos, apenas o veículo apropriado para a interpretação de uma realidade que se desdobra em vários planos verticais (e não horizontais, como seria o caso no romance regionalista). (Martins, W., 1970, p.xxi-xxii, grifo nosso)

Por essa ponderação, entende-se que Rosa igualmente não seria um autor regionalista, pois, na concepção do crítico, o regionalismo corresponderia a "planos horizontais" da realidade, a uma realidade rasa, portanto, sem profundidade. Assim, sem aceitar a possibilidade de que obras regionalistas tenham "profundidade" psicológica, o crítico opta por definir $O$ coronel e o lobisomem como um "romance urbano", "psicológico". Mas, ao atribuir nuances diferenciadas às definições empregadas aos autores, Wilson Martins reconhece o aspecto social da obra de José Cândido:

[... se a metafísica em Guimarães Rosa é, antes de tudo, psicológica, a psicologia, em José Cândido de Carvalho, é, sensivelmente, "social", ou, se quisermos, grupal. Mas, ainda aqui, convém não simplificar em excesso: o Coronel é, desde a primeira linha, um excêntrico, ou seja, um tipo fora da norma. (p.xxii)

No entanto, o aspecto social do romance é novamente suplantado pelo plano psicológico que o crítico, inclusive, usa de argumento para reprovar a obra de José Lins do Rego - crítica que já vinha sendo insinuada desde o princípio do ensaio, com o ataque ao "romance social" dos anos 1930 e seus seguidores: 
[...] José Cândido de Carvalho conseguiu superar a aflitiva incapacidade de José Lins do Rego em criar uma psicologia definida, consistente e sobretudo convincente: o "ciclo da cana-de-açúcar" é obra de um primitivo, de um contador oral; já José Cândido de Carvalho, em sua fase atual, é o escritor (como Guimarães Rosa), o homem para quem a literatura é literatura. (p.xxiii, grifo nosso)

Observe-se, portanto, que, na compreensão do crítico, as noções de primitivismo e narrativa oral adquirem conotação claramente pejorativa ao serem utilizadas para atacar Lins do Rego. Desse preconceito cosmopolita decorre, obviamente, o fato de não aceitar que a obra de José Cândido possa se relacionar à vertente regionalista. O trecho final também insinua que, para ele, as obras de inclinação social não seriam propriamente literatura.

Como Cavalcanti Proença reconhece a importância da literatura regional ao tratar do romance, os críticos nesse ponto se afastam, portanto, radicalmente. Apesar dessa dissonância, verifica-se, por outro lado, a confluência das opiniões dos ensaístas a respeito dos elementos sobrenaturais do romance. Compreendendo a dimensão insólita da narrativa também como uma criação da mente do herói, Wilson Martins (p.xxi) fala em "combates imaginários" do "velho Quixote" Ponciano e se utiliza da ideia da "loucura criadora e poética" para explicar o final da narrativa. Logo, quanto a esse aspecto, sua leitura encontra sintonia com a de Proença, bem como com as de Nejar e Castello.

Por ora, dessa excursão pelos juízos encontrados na historiografia literária brasileira nos ensaios mencionados que tratam do romance de José Cândido de Carvalho, reconhece-se, no geral, certa constância na escolha dos tópicos a serem discutidos sobre a obra, embora, no saldo, as conclusões sejam as mais diversas, ainda que partam de um mesmo ponto. No plano das semelhanças, a inclusão do autor no Modernismo parece, com exceção de Nejar, ser uma constante entre os críticos; verifica-se também a recorrência de autores nos vários intertextos resgatados, com destaque para Guimarães Rosa; nota-se a valorização da linguagem em sua inextrincável relação com a figura de Ponciano, bem como com o êxito pela construção psicológica do 
protagonista; todos os críticos acabam também por apontar aspectos sobre a quase inescapável dimensão social do romance, ainda que discordem sobre a importância que a esse aspecto se deve conceder. No entanto, apesar dos pontos de contato, chama a atenção, diante do panorama dessas leituras, o desacordo existente entre os diferentes posicionamentos sobre a relação da obra com o regionalismo, impasse aparente, sobretudo quando os críticos procuram situar o autor na tradição literária. Sobre o plano mágico da narrativa, outro ponto polêmico, percebe-se que a tendência dos autores que o discutiram - há os que sequer o mencionam - foi justificá-lo pela capacidade inventiva do narrador-protagonista, como se os episódios insólitos não passassem de invenções deliberadas ou crenças imaginárias da personagem, à semelhança dos contadores de história, e não como uma realidade representada pela narrativa.

\section{O lobisomem no sertão: regionalismo e insólito nos estudos críticos de $O$ coronel e o lobisomem}

O problema que se visualiza diante desse quadro geral da historiografia, e que não foi resolvido plenamente pela fortuna crítica mais recente do autor, consiste na falta de uma leitura unificada e integradora das seguintes questões suscitadas pelo romance - por si só bastante complexas, mas ainda pouco discutidas, mesmo que isoladamente: a averiguação da pertinência e implicações de se pensar a obra em relação ao regionalismo literário e a investigação minuciosa da conformação e função dos elementos insólitos na narrativa. Acredita-se que uma análise que congregue essas perspectivas pode abrir novos caminhos à "leitura do sertão nacional como lócus do insólito”. ${ }^{4}$ A compreensão da obra em relação à ideia

4 Emprestamos a expressão da descrição do Simpósio "Um ser tão fantástico: temáticas e configurações do sertão insólito”, coordenado por Alexandre Meireles da Silva e Roberto Henrique Seidel, realizado no II Congresso Internacional Vertentes do Insólito Ficcional, de 28 a 30 de abril de 2014, no Rio de Janeiro (UERJ). 
de regionalismo - como já se demonstrou e como ainda se verá em outros autores - é pouco pacífica entre a crítica do romance, cujos conceitos e pré-conceitos precisam ser compreendidos, hoje, no contexto em que se firmaram, pois é notório que carecem de atualização. Do mesmo modo, sobre a "dimensão irrealista" da obra, apesar de parecer haver um consenso entre algumas das opiniões apresentadas (Proença, Castello, Nejar), explicando que são invencionices do narrador, verifica-se que a questão, principalmente a partir de 1970, deixa de ser consensual entre a fortuna crítica do romance. A confirmação mais expressiva dessa constatação são as publicações dos livros: Realismo mágico, de José Hildebrando Dacanal, em 1970, e Do mito ao romance: tipologia da ficção brasileira contemporânea, de Regina Zilberman, em 1977. Ambos os estudos contemplam a dimensão do insólito no romance $O$ coronel e o lobisomem e também em Grande sertão: veredas, além de outras obras, mas os autores adotam perspectivas diferentes ao fazê-lo, sendo que até hoje não houve um estudo que retome e avance propriamente essas discussões como ponto central da análise. ${ }^{5}$

A década de 1970, em que surgem esses estudos, demonstrou-se propícia para despertar tais questionamentos a respeito do insólito, pois foi nessa época que Cem anos de solidão começou a conquistar espaço no mercado literário brasileiro, aparecendo nas listas de livros mais vendidos do país e figurando, inclusive, ao lado do romance $O$ coronel e o lobisomem, conforme se verificou durante esta pesquisa. ${ }^{6,7}$ Seria também nessa década, em meados de 1975, que

5 Exceções são a dissertação O lobisomem do coronel Ponciano, de Célio José Vieira (1984), o artigo "O maravilhoso como ponto de convergência entre a literatura brasileira e as literaturas do Caribe", de Zilá Bernd (1998) e a dissertação No mato brabo da ficção: estudo sobre José Cândido de Carvalho, de Edna da Silva Polese (2005), as únicas publicações localizadas que, embora tangencialmente, tocam nos problemas aqui levantados.

6 Cf. Os mais vendidos nos estados. Jornal do Brasil, Rio de Janeiro, 30 jan. 1971, Suplemento Livro, p.10.

7 Durante esta pesquisa, localizou-se um anúncio, publicado no Jornal do Brasil (19 dez. 1975, Caderno B, p.3), intitulado "Edição latina”, em que se divulgava a edição em língua espanhola do romance $O$ coronel e o lobisomem. A 
o crítico e ficcionista Bernardo Élis, já mencionado entre os autores da época, constataria essa nova dimensão representacional na obra de José Cândido de Carvalho - a qual Élis também explora em seus livros - e, utilizando-se um tanto indistintamente de alguns termos, procuraria, no encerramento de "Tendências regionalistas no modernismo”, se não explicar o fenômeno, ao menos sugerir-lhe um novo viés de análise:

Ainda devíamos abordar aspectos fundamentais da literatura moderna como seja o aproveitamento do mágico, do fantástico, do imaginoso e o mítico ou alegórico, a exemplo do que se encontra em José Cândido de Carvalho, Ariano Suassuna e outros, tudo dentro da melhor tradição do nosso fabulário popular do tipo das infindáveis aventuras de pedros malasartes, e outras estórias em que o fantástico, o poético, o místico, o imaginoso é a substância responsável por sua sustentação e desdobramento. Por aí entraríamos num dos filões mais extraordinários e bem pouco estudados de nossa literatura oral. (Élis, 1975, p.101, grifo nosso)

Como é possível observar, já em meados da década de 1970 apontava-se a falta de estudos sobre esse aspecto do romance de José Cândido, questão que ainda hoje permanece em suspenso. Na verdade, a área de estudos sobre o "novo fantástico" brasileiro (denominação genérica para designar o fenômeno) ainda está se consolidando, conforme demonstra o artigo "Antecedentes conceituais e ficcionais do realismo mágico no Brasil”, de autoria de Milton Hermes Rodrigues (2009), pesquisador que menciona a obra de José Cândido para

nota afirmava que o livro seria lançado em 1976, pela editora Sudamericana, a mesma que editava a obra de Gabriel García Márquez. E, completava: "García Marquez, aliás, é quem assina a apresentação do livro de José Cândido de Carvalho, onde afirma que $O$ coronel e o lobisomem é sem dúvida um dos momentos mais altos da literatura latino-americana”. De fato, a obra ganhou sua edição em espanhol no ano indicado e por essa mesma editora, no entanto, a apresentação foi feita pela tradutora do romance e não há nenhum outro paratexto na obra assinado pelo escritor colombiano. 
tratar da questão do insólito. Considerando-se as produções teórico-críticas nacionais sobre o insólito ficcional brasileiro do século XX, levantadas pelo autor em sua busca pelos "antecedentes conceituais" dessa categoria, percebe-se que poucos são os críticos que trataram da questão e, entre os que se destacam, encontram-se justamente os estudos pioneiros de Dacanal e Zilberman. Rodrigues (2009), assim como Dacanal, opta pela denominação "realismo mágico" para designar as manifestações do "novo fantástico", por reconhecer ser o termo mais usual entre a crítica.

De fato, embora Zilá Bernd (1998), outra pesquisadora que tratou do insólito em $O$ coronel e o lobisomem, preferisse o termo realismo maravilhoso, adotando as concepções de Irlemar Chiampi (1980), realismo mágico é a forma mais comumente utilizada, o que se confirma tendo em vista algumas publicações recentes que fazem uso desse termo (ou de sua variação, "realismo fantástico") para se referirem à obra. Assim ocorre, por exemplo, em um artigo assinado por Paulo Bentancur (2009, p.12), no jornal literário Rascunho, intitulado "Humor e magia":

José Cândido de Carvalho achara o jeito. Tinha o radicalismo de Guimarães Rosa, quebrando todas as normas, e possuía, ao mesmo tempo, um jeito seu, único, de ser menos formal que Rosa e mais fabulista. Acrescentando-se aí o humor - ausente em Rosa - e o Realismo Mágico, tão em voga naquela década na América Latina (não esquecer um certo eco da literatura de cordel). Se Rosa exige três leituras para que nos afeiçoemos à voz do narrador, José Cândido precisa de uma só, ainda que sua linguagem seja, sob vários aspectos, renovadora.

Utilizando-se de uma variação do termo, Cícero Sandroni, na orelha do livro $A B C$ de José Cândido de Carvalho, afirma ser o romance $O$ coronel e o lobisomem "pioneiro no realismo fantástico latino-americano, hoje pedra de toque da literatura brasileira". Também nessa obra, a crítica Cláudia Nina (2011, p.63), recuperando uma das cenas do romance (a luta entre o galo Vermelhinho e uma 
cobra surucucu), afirma tratar-se de "um lance flagrante de realismo mágico”. Essa publicação da José Olympio torna-se sugestiva ainda à abordagem aqui proposta, pois além das referências à dimensão insólita do romance, promove (ou reassegura) igualmente a identificação da produção do autor, de um modo geral, à vertente regionalista: a obra integra um projeto que se volta também (sob o mesmo título $A B C$, como referência à literatura de cordel) aos escritores nordestinos José Lins do Rego, Rachel de Queiroz e Ariano Suassuna. Em outros termos, o mercado editorial continua legitimando a associação do campista José Cândido de Carvalho à literatura regionalista e não se pode desconsiderar isso.

Mas, afinal, sob quais perspectivas a dimensão insólita do romance foi compreendida pelos estudos de José Hildebrando Dacanal, Regina Zilberman e Zilá Bernd, autores que mais se dedicaram a essa discussão? A primeira observação que se deve fazer, de antemão, é que nem todos buscaram articular essa dimensão do romance ao conceito de regionalismo, relação que este trabalho tem buscado sondar. Outro ponto a salientar é que essas publicações têm naturezas e propósitos distintos, sendo as duas primeiras livros e a terceira, um artigo. Finalmente, cumpre esclarecer que, neste percurso, serão visitadas também opiniões de outros nomes da crítica que fomentaram a polêmica gerada em torno dessas questões, ampliando o panorama de leituras da obra.

A análise que o crítico literário gaúcho José Hildebrando Dacanal, então recém-graduado e já professor da UFRGS, ${ }^{8}$ realiza do

8 Em depoimento presente em sua tese de doutorado, sob orientação do prof. Luís Augusto Fischer, José Hildebrando Dacanal (2008, p.72) recupera dados de sua trajetória profissional, relacionados ao período em questão: "Em março de 1967 comecei a trabalhar como tradutor/redator e eventualmente repórter/editor do Correio do Povo. Em abril, ingressei por transferência no curso de Letras da Universidade Federal. Em 1968 li, pela primeira vez, obras da ficção brasileira. Colei grau em 1969. Em maio de 1970 comecei a dar aulas de Literatura Brasileira no mesmo curso, a convite dos profs. Flávio Loureiro Chaves e Guilhermino César. Em agosto publiquei Realismo mágico, um conjunto de ensaios sobre Grande sertão: veredas, $O$ coronel e o lobisomem e Fogo morto. Em novembro, agraciado com uma bolsa de estudos pelo Serviço 
romance $O$ coronel e o lobisomem corresponde a um dos três ensaios que compõem o livro Realismo mágico, lançado pelo autor em 1970. Os outros dois textos que o integram são voltados aos romances Grande sertão: veredas e Fogo Morto. No prefácio, intitulado "A desmagicização do mundo”, José Dacanal apresenta os pressupostos metodológicos que fundamentam as análises das obras: enquanto o romance de José Lins do Rego conta com uma interpretação "genético-estrutural”, a abordagem dos outros dois livros, sem apresentar "inovação maior do ponto de vista da metodologia crítica", demonstraria a preocupação do autor "com uma problemática sócio-histórica" de "profundas repercussões no campo da literatura" (Dacanal, 1970, p.9), situação que estaria sendo negligenciada pelos estudos literários brasileiros de seu tempo. O estudioso explica, então, que esse problema estaria relacionado ao chamado "ciclo do romance latino-americano", fenômeno literário que representaria um "corte" na literatura ocidental:

A afirmação de que Cem anos de solidão, O coronel e o lobisomem, Grande sertão: veredas, para citar apenas as mais importantes, renovam a técnica da narrativa, é insuficiente. Se for permitido falar ainda em termos da retórica clássica, poder-se-ia dizer, talvez, que tais obras quase fazem parte de um novo gênero literário ou, pelo menos, que estão a exigir uma classificação nova. (Dacanal, 1970, p.9, grifo do autor)

Na continuação de seu raciocínio introdutório, o crítico defende que mais do que a uma renovação da técnica narrativa, a ruptura instaurada por essas obras no cenário literário estaria relacionada a um abandono da verossimilhança, pressuposto correspondente à consciência lógico-racionalista que norteava a produção de matriz europeia. Em suas palavras,

Alemão de Intercâmbio Acadêmico (DAAD), parti para a Alemanha, tendo na cabeça o projeto de escrever uma tese de doutorado comparando a natureza da narrativa fantástica europeia com as obras do então chamado realismo mágico latino-americano". 
Esta "continuidade racionalista", como poderia ser classificado este traço que informou toda a literatura ocidental, desemboca numa consequência inevitável: o mágico ou o fantástico sempre foram trabalhados a partir de uma perspectiva racionalista; fazendo ver e sentir que se tratava do incomum, do não natural, do fora da série (Sue, Hoffmann, Walpole); creditando-o à anormalidade individual do herói (Dostoiévski, Cervantes) ou passando decididamente para o terreno da alegoria, do simbólico, como é o caso de Swift ou de Kafka [...].

O mágico, o maravilhoso em sua naturalidade, o mítico, ou como quer que o denominemos, somente agora, nas literaturas do Terceiro Mundo, passou a fazer parte da narração romanesca. [...] Urge abandonar o real-naturalismo (e derivados) e analisar o romance latino-americano a partir dele próprio, como fenômeno integrante de um outro mundo que não o europeu, de outro milieu que não o mediterrâneo. (p.10, grifo do autor)

Contextualizando esse fenômeno, o crítico lembra que o romance do chamado realismo mágico aparece com maior intensidade em países como Colômbia, Guatemala, México e Peru, justamente aqueles em que as culturas autóctones possuem vigor inquestionável ou representam um dado essencial na constituição histórica de seu povo. No cenário brasileiro, Dacanal (p.11) aproxima os casos de José Cândido e de Guimarães Rosa, justificando que as obras de ambos tematizam "o homem do interior que perdera o contato com os centros urbanizados da orla atlântica brasileira”. Essas ocorrências se distinguiriam dos romances brasileiros dos anos 1930, já que, nestes - embora em geral o espaço corresponda a áreas interioranas e os heróis, por vezes, sejam vistos a partir deles próprios -, conservava-se a perspectiva do homem citadino.

Essa transformação verificada no âmbito literário estaria relacionada a um momento histórico em que os povos dos países do então chamado terceiro mundo passariam por um despertar cultural, consequência do enfraquecimento do poder político da Europa, e se reconheceriam também como agentes da história. $\mathrm{O}$ ciclo do romance 
latino-americano que, segundo o autor, teria se iniciado em 1950 procederia e se integraria nesse novo episódio da história política do mundo. Desse modo, Dacanal (p.11), em sintonia com os estudos latino-americanos de seu tempo e estimulado declaradamente pelas ideias de Alejo Carpentier, reitera: "Se isto for ignorado creio impossível compreender a fundamental importância de obras como Cem anos de solidão, Grande sertão: veredas, O coronel e o lobisomem e $O$ reino deste mundo".

Nesse sentido, o crítico argumenta que os romances de Guimarães Rosa e de José Cândido são "obras essenciais do 'realismo mágico" e que busca analisá-las "como sendo o contraponto artístico do fenômeno histórico da desmagicização do mundo entrevisto por Max Weber" (p.12, grifo do autor). A continuação desse trecho merece ser transcrita, pois é quando o ensaísta reconhece que, embora se trate de um fenômeno promovido por nações periféricas, há nelas uma elite que o encoraja. Em outras palavras, há uma elite no interior dos países periféricos, que seria a real responsável por idealizar tais transformações:

[...] agora começa a ser sentido com toda a violência o choque entre o Ocidente que avança e os povos extraeuropeus que se rebelam tentando, consciente ou inconscientemente, defender suas culturas autóctones, no que são apoiados pelas elites que, no interior da própria civilização pragmático-racionalista, começa, a contestá-la violentamente. (p.12)

A fundamentação que subjaz ao discurso de Dacanal encontra-se nas formulações sobre o "real maravilhoso", como expressão literária de caráter latino-americano, propostas por Alejo Carpentier, autor explicitamente mencionado no prefácio do livro do crítico brasileiro. No entanto, Dacanal opta, sem maiores explicações, pelo termo "realismo mágico", permitindo-se entender que o utiliza como sinônimo do outro conceito. A categoria denominada "realismo mágico" possui um sentido mais abrangente, uma vez que, em seu emprego pela crítica, não se restringe a recobrir manifestações do 
"novo fantástico" em territórios da América Latina, sendo conceito de comum utilização em análises de obras de países do hemisfério norte, como ocorre com a produção da escritora inglesa Ângela Carter.

Já o ensaio dedicado ao estudo do romance de José Cândido, intitulado "Entre o mítico e o sacral", é composto por uma introdução e três subdivisões, nas quais são analisadas, respectivamente, a estrutura da obra, a decadência do herói e o conflito entre o plano mítico e o racional.

Inicialmente, Dacanal (p.30) revela considerar O coronel e o lobisomem "uma das quatro ou cinco obras mais importantes da literatura brasileira", equiparando-o, nesse sentido, aos romances Quincas Borba, São Bernardo e Grande sertão: veredas. Em semelhança a este último, o romance de José Cândido apresentaria como característica essencial justamente o abandono do real-naturalismo, propiciando a manifestação de uma concepção de mundo mítico-sacral. No entanto, ainda em sua visão, as obras difeririam pelo trabalho com a espacialidade: o romance de Rosa apresentaria uma paisagem mais fluida, menos localizável e de difícil apreensão por estudos de sociologia, enquanto o de José Cândido retrataria um mundo "mais natural" (p.31), com grupos sociais mais facilmente apreensíveis. A dissimetria apontada entre as obras parece justificar-se na medida em que sugere a ideia, inquestionável, da existência de uma dimensão metafísica que, na obra de Guimarães Rosa, a paisagem adquiriria. No entanto, é sabido que o romance do escritor mineiro "suporta", como o do campista, uma leitura sociológica, no sentido de que permite o reconhecimento de grupos sociais pertencentes a uma espacialidade e temporalidade históricas específicas, representadas literariamente. Por essa razão, tal diferença que alega haver entre as obras parece inconsistente para seu intuito de justificar o que na sequência afirma:

Ninguém, de são juízo, qualificaria Grande sertão: veredas como romance regionalista. Mas foi assim que Raquel de Queiroz se referiu a $O$ coronel e o lobisomem. Com certa razão. Esta é a grande diferença entre as duas obras, refletida, aliás, na própria linguagem. A 
que "conta" o mundo de Riobaldo é mais construída. A de Ponciano mais natural, se bem que ambas tenham em comum aproximar-se do "mundo original das coisas", do significado, desmascarando-os das camadas de artificialidade adquiridas pelo significante através do uso e do tempo. (p.31, grifo do autor)

De fato, retomando o início da passagem, ao compreender o regionalismo como um indicador de obras limitadas esteticamente, puramente documentais, anacrônicas, desprovidas de sentidos universais significativos a homens de qualquer época ou espacialidade e produtoras de personagens típicas, sem complexidade psicológica, seria absurdo utilizar o termo para pensar o romance de Guimarães Rosa. Dessa perspectiva, não seria igualmente inadequado afirmar que o romance de José Cândido integraria o rol das obras regionalistas? Por que, então, essa a diferença entre as obras? O argumento de que apenas uma resistiria a uma leitura de inclinação sociológica parece não proceder, haja vista a quantidade de trabalhos críticos que buscam discutir a formalização estética de conflitos históricos nacionais no romance de Rosa. Afinal, se há no romance de José Cândido a representação da decadência dos coronéis, como afirma o crítico, no de Rosa, visualiza-se, é impossível negar, uma realidade semelhante vivenciada pelos jagunços em um sistema de ordem em crise. ${ }^{9}$ Não bastassem esses desacertos que se impõem na introdução, no capítulo destinado ao exame do romance de José Cândido, Dacanal parece se esquecer do argumento que utilizara anteriormente para justificar a pertença ao regionalismo de uma e não da outra obra e afirma, sobre $O$ coronel e o lobisomem:

Ao se tentar uma análise inicial [d'O coronel e o lobisomem] em termos da crítica sociológica tradicional - perfeitamente possível, válida e, mais ainda, absolutamente necessária em José Lins do

9 O próprio crítico chegaria a afirmar, posteriormente, que um dos pontos que gostaria de trabalhar com mais afinco em sua interpretação sobre Grande sertão: veredas seria justamente "a matéria histórica” da obra, como "os fenômenos do coronelismo e da jagunçagem na República Velha” (Dacanal, 1988, p.6). 
Rego, por exemplo, e tantos outros - tudo escorre pelos dedos. [...] Sob este ângulo, O coronel e o lobisomem é quase tão fluido quanto Grande sertão: veredas. (p.35)

Assim, o próprio crítico se contradiz e anula sua justificativa. Afinal, Grande sertão: veredas seria ou não uma obra regionalista? Encurralado entre uma voz de autoridade que afirma o regionalismo em $O$ coronel e o lobisomem e a pressão de uma visada "transcendental", "universal", comum às análises de Rosa - sem contar o peso da carga pejorativa que o termo adquiriu na crítica brasileira - o ensaísta opta por uma saída frágil e incapaz de sustentar sua tese de que constituiriam casos distintos. Tanto é que - por esse viés, sem critérios com que aprofundar sua argumentação, além de contradizer-se - o crítico procura amparo para sua tese na diferenciação do tratamento da linguagem entre os romances. Porém, essa alternativa se mostra igualmente frustrada, não só porque se exime de explicar como exatamente a linguagem poderia determinar o caráter regionalista de uma obra e não da outra, mas também porque, como se viu, termina por admitir as semelhanças entre os romances, mesmo no plano linguístico. Assim, fica a impressão de que a necessidade de justificar o regionalismo de um dos romances e negar o do outro é o que o força a buscar explicações conflitantes entre si.

$\mathrm{Na}$ sequência, Dacanal argumenta que $O$ coronel e o lobisomem seria o mais radical dos dois romances, no sentido de que nele a oposição entre o real e o mítico se daria de maneira mais violenta: enquanto Ponciano se movimentaria entre dois planos irreconciliáveis, Riobaldo pertenceria a um mundo mais unitário e coeso. Assim,

Riobaldo caminha de uma concepção mítico-sacral da História e do mundo até chegar ao plano de um existencialismo agnóstico, onde se detém ("Existe é homem humano. Travessia.") Sua trajetória espiritual é linear. Ponciano, ao contrário, é dilacerado pela atração dos opostos. (p.31, grifo do autor) 
A tensão a que Ponciano estaria sujeito decorreria do fato de viver "num tempo que não é mais o seu" e se debater entre a atração de um mundo semiurbanizado (a cidade de Campos dos Goytacazes) e um mundo perdido do interior, o Sobradinho, "ainda estruturado em bases mítico-sacrais, no qual o lobisomem e a sereia são aceitos como seres naturais, reais, que integram o acontecer normal da existência" (p.31, grifo do autor). Por fim, dessa tensão insolúvel resultaria a autodestruição do herói. Observe-se que os eventos sobrenaturais, especificamente os de natureza folclórica, como os casos do lobisomem e da sereia, são compreendidos na leitura de Dacanal como "realidades" no interior da narrativa, episódios, portanto, em harmonia com o mundo mítico do herói, e não resultantes de mera criação da mente de Ponciano, que viveria sob um mundo regido por uma normalidade convencional e apenas fantasiaria suas ações. A leitura do crítico procura, com isso, não "racionalizar" o romance, ou seja, não violentar o caráter insólito da narrativa, aceitando-o como realidade possível no universo da obra de José Cândido.

A estrutura do romance reafirmaria também esse caráter extraordinário da narrativa, ou mítico, como afirma o crítico, pois, segundo ele, o primeiro plano narrativo, que se inicia quando Ponciano se apresenta antes de começar a narrar suas memórias, não se fecha ao final da ação. Depois que o narrador realiza um flashback para contar como foi sua vida desde a infância, iniciando o segundo plano da narrativa, não há mais retorno ao primeiro, que corresponde, acrescente-se, ao momento da enunciação, conforme visto aqui anteriormente ao se cotejar as obras do autor.

Dacanal (p.33) explica o fenômeno se utilizando do termo "fantástico": "O coronel e o lobisomem se encerra com o fantástico - nos dois sentidos - episódio da luta contra 'o pai de todas as maldades', episódio completamente ambíguo dentro da estrutura da narrativa da obra". O uso do termo "fantástico" pelo crítico parece abranger não só seu sentido genérico, como algo fora do comum ou fantasioso, mas também sugere estender-se, pela ideia de "ambiguidade", ao sentido específico que possui na teorização de Tzvetan Todorov (1975), como aquilo que hesita entre o natural e o sobrenatural. 
Nesse ponto, aceitando-se que a ideia do fantástico associada à ambiguidade pode evocar a terminologia todoroviana, reconhece-se um desencontro na fundamentação teórica do raciocínio: as categorizações do fantástico e do realismo mágico não apresentam a mesma significação, não devendo ser tomadas como sinônimos. A razão principal da diferença decorre das várias modalidades de manifestação do insólito: nas narrativas do fantástico, permanece a ambiguidade sobre a naturalidade ou não do evento incomum, enquanto que, nas produções do chamado realismo mágico, o acontecimento extraordinário é aceito como tal no interior da narrativa, não restando dúvidas quanto ao caráter sobrenatural e racionalmente inexplicável do evento.

Recuperando o final do romance, momento em que Ponciano manifesta sintomas de abalo mental e sente uma dor aguda no peito, Dacanal sonda a composição estrutural da obra, exercício de análise já aqui parcialmente empreendido:

O leitor que prestara atenção à construção técnica da narrativa fica confuso. É o delírio que seria narrado nos "deixados" pelo próprio Ponciano? É a morte, e Ponciano seria também um "defunto autor"? Ou o "retorno ao real" ocorreria naturalmente como nos episódios da sereia e do lobisomem? Se assim fosse, o círculo narrativo poderia cerrar-se com a volta ao real, somente que agora se trataria do retorno ao primeiro parágrafo do livro.

Seja como for, a estrutura narrativa do romance de José Cândido de Carvalho levanta espinhosas e fascinantes interrogações que não podem encontrar solução técnica no âmbito dos padrões narrativos tradicionais (como o "defunto autor" de Machado explica bem o que ele é e esclarece tudo perfeitamente!) nem podem ser explicadas, o que a mim pareceria ridículo, como falhas da própria estrutura. $\mathrm{O}$ melhor é tentar estabelecer se, na verdade, não estamos diante de uma obra de outra natureza que a da novela tradicional e do romance do real-naturalismo, o que exigiria certa reformulação de conceitos. (Dacanal, 1970, p.33-4) 
A despeito do aparente amálgama de teorizações incompatíveis, o crítico lança perguntas importantes à compreensão da estrutura narrativa do romance, mas as deixa em aberto com um "seja como for", desobrigando-se da necessidade de examinar o fenômeno com maior profundidade e rigor analítico. No entanto, na parte final do ensaio, ele se volta ao conflito que define como a oposição entre o mítico e o racional e propõe uma leitura profícua à esfera insólita da narrativa, alegando que as abordagens sociológica e psicológica, úteis a obras do real-naturalismo, são insuficientes para atender à composição do romance de José Cândido. Assim, lança a tese que irá defender:

Neste momento de impasse [insuficiência das abordagens sociológica e psicológica] se revela a grandeza do romance [O coronel e o lobisomem] que surge como obra ímpar que, ao lado de Grande sertão: veredas, cria em definitivo o novo dentro da ficção brasileira que até agora permanecera, a grosso modo, em dois planos: o regionalista e o urbano. Em nenhum deles se enquadra Ponciano. Porque a trajetória e a tragédia de Ponciano, como a caminhada de Riobaldo, são de outra natureza. Elas oscilam entre dois polos de atração: o mítico-sacral e o racional. Eis em que tudo se resume. (p.36, grifo do autor)

Note-se que, novamente, o regionalismo é negado ao romance. De qualquer modo, para negá-lo foi preciso mencioná-lo e, talvez, ao defender a existência de um novo dentro da ficção brasileira, o crítico não esteja tão distante da percepção de Rachel de Queiroz, ao afirmar que José Cândido estaria, com esse romance, dando vida nova ao regionalismo. $\mathrm{Na}$ sequência, os dois polos que visualiza em ambos os romances corresponderiam, segundo ele, a dois mundos, ou ainda, a duas concepções de mundo. No caso do romance de José Cândido, essas diferentes concepções estariam representadas na espacialidade agrária do Sobradinho e na semiurbanizada de Campos dos Goitacazes que, nesse sentido, não seriam apenas duas estruturas socioeconômicas, mas funcionariam também como símbolos dessa oposição. O herói Ponciano viveria o choque entre essas duas concepções de mundo, entre essas duas culturas, que manifestariam, 
nele, uma luta entre dois planos de consciência, o mítico e o racional. Esse embate seria diferente do vivenciado por Rubião, protagonista de Quincas Borba, pois no caso deste as contradições decorreriam de apenas um plano de consciência, enquanto Ponciano apresentaria dois planos, correspondentes a essas dimensões em choque que, aliás, estruturariam a narrativa. Ponciano, seria, portanto, o herói dilacerado entre dois mundos:

Ponciano autodestrói-se porque compreende que o conflito em que se embate é insolúvel e só resta o desaparecimento; sua consciência, a do plano mítico-sacral, entrara em crise ao contato do agrupamento semiurbanizado e teria obrigatoriamente que desaparecer de maneira completa diante do plano racional. Contudo, o plano mítico-sacral fazia parte integrante, era a sua própria personalidade. O impasse não tem saída. A solução: o autodestruir-se, o desaparecer. O sacral não tem mais lugar no mundo. Ou se transforma, negando-se [refere-se a Riobaldo], ou resiste e cai [Ponciano]. Nos dois casos é o desaparecimento. (p.37, grifo do autor)

O alternar-se dos planos na consciência de Ponciano resultaria em sua personalidade contraditória, aparente quando, em certos momentos, ridiculariza a concepção de mundo vigente no campo, por suas crendices e, em outros, vive essa dimensão, "abraça a sereia, desencanta o lobisomem ou luta contra 'o pai de todas as maldades"” (p.37). Construída dicotomicamente entre os mundos do campo e da cidade, a psicologia de Ponciano não poderia ser apreendida por categorias provenientes de uma consciência unívoca e racionalista. Aos que pudessem alegar, de um ponto de vista racional, tratar-se de artifícios, "elucubrações mais ou menos justificadas", Dacanal sentencia: "O conflito mencionado transparece com clareza meridiana no texto". Assim ocorreria também com a estrutura da obra, que oscilaria entre "o plano racional, realista, e o mítico-sacral, fantástico, mágico, ou como se quiser chamá-lo” (p.37). Para ele, a narrativa terminaria no "plano do fantástico", gerando, pelo capítulo final, uma "irracionalidade estrutural" na obra (p.37). 
Embora possa parecer, a partir da perspectiva de Ponciano, que ao final o sacral se impõe ao racional, o conflito visto "de fora" demonstraria o contrário, ou seja, observada de um ângulo externo, a destruição do herói - ou autodestruição, como o crítico compreende - significaria a vitória da consciência racional sobre a sacral. O herói de Grande sertão: veredas, por sua vez, não desapareceria ou se autodestruiria, pois teria conseguido "evoluir" - para usar a palavra do ensaio - "até o ponto de negar completamente o mundo mítico-sacral e aceitar só e unicamente o mundo racional, num plano agnóstico-existencial” (p.39). Esse ponto da argumentação de Dacanal merece uma ressalva, porque, conforme leitura de Eduardo Coutinho (2013), Riobaldo é um homem atormentado pela ideia de ter vendido a alma ao diabo, sem, no entanto, ter certeza se ele realmente existe. Assim, a narração de sua vida a seu interlocutor, homem urbano de passagem pelo sertão, se faz com o propósito de tentar, com a ajuda dele, sanar essa dúvida que o angustia. E Coutinho confirma o fato resgatando as seguintes palavras que Riobaldo dirige a seu interlocutor: "Quero é armar um ponto dum fato, para depois lhe pedir um conselho. [...] Conto ao senhor é o que eu sei e o senhor não sabe; mas principal quero contar é o que eu não sei se sei, e que pode ser que o senhor saiba" (Rosa apud Coutinho, 2013, p.80-1). Com este último trecho que, deve-se reconhecer, poderia sintetizar todo um tratado da função da psicologia, fica notório que Riobaldo não é um homem tão racional e livre de suas "crendices" como quer a análise de Dacanal (1970, p.39): "Riobaldo evolui, estabelece um 'compromisso', chega ao plano da consciência racional sem cair na 'consciência problemática' que ora é o apanágio do Ocidente. De qualquer forma, renega o plano da consciência sacral".

Em todo caso, o crítico estabelece essa distinção entre Ponciano e Riobaldo para concluir que esses heróis apresentam as duas únicas saídas para as "ilhas de consciência mítico-sacral" que ainda existiriam no mundo diante do avanço da civilização pragmático-racionalista: ou a autodestruição ou a negação do mundo mítico. Em ambos os casos, no entanto, o mundo mítico-sacral estaria condenado a desaparecer. E, para concluir, Dacanal recupera Cem anos 
de solidão lembrando que o fenômeno, não sendo exclusividade da literatura brasileira, manifesta-se também no restante do continente latino-americano:

Riobaldo e Ponciano se identificam, enfim, porque um e outro personificam a condenação destas "ilhas". Seu futuro é sem esperança. Na negação consciente de si próprias ou na revolta suicida o resultado final é o mesmo: o desaparecimento. É curioso, se não sintomático, que outra grande obra como Cem anos de solidão, do colombiano Gabriel García Márquez, esteja centralizada sobre este problema. Mais curioso é que termine com um furacão apocalíptico que varre a aldeia de Macondo da face do planeta "porque as estirpes condenadas a cem anos de solidão não tinham uma segunda oportunidade sobre a terra". (p.39)

A recepção desse livro de José Hildebrando Dacanal encontra certa resistência na leitura de Wilson Martins. Um ano após o lançamento do livro, Martins o comenta, juntamente a outros títulos de crítica literária, em uma resenha intitulada "A prática da teoria", publicada no jornal O Estado de S. Paulo, em 15 de agosto de 1971, texto que pode ajudar a esclarecer a motivação das atualizações realizadas posteriormente pelo ensaísta gaúcho. Nele, o crítico já consagrado Wilson Martins comenta o que, em sua perspectiva, configurariam os erros e acertos da análise de Dacanal. Assim, antes de saltar ao ano de 1977 para conhecer o olhar de Regina Zilberman sobre o assunto, faz-se oportuna uma breve excursão por essas e outras reflexões da crítica literária que, construída nos jornais da época, se ocupou em situar o romance de José Cândido de Carvalho.

$\mathrm{Na}$ resenha que faz do livro Realismo mágico, Wilson Martins (1971, p.4) refere-se a Dacanal como "um crítico em processo de amadurecimento", considerando-o um tanto deslumbrado pelas "cintilações das doutrinas e dos nomes (Lukács, Lucien Goldmann) e ainda insuficientemente seguro das inexoráveis realidades da história literária e da história propriamente dita”. Acusa ainda as técnicas de interpretação dos ensaios de pouco sistemáticas, 
fragmentárias e fundadas em noções arbitrárias ou incorretas. O crítico se mostra bastante incomodado, principalmente com a ideia de que os romances analisados poderiam integrar um "ciclo do romance latino-americano”, o que considera um disparate. (Deve-se lembrar que, ainda nessa época, o Brasil era um país praticamente à margem das discussões sobre a América Latina, tomada então quase que como sinônimo de América Hispânica.) Nesse sentido, Martins ataca ainda a análise de Fogo morto, explicando o que seria a noção de "ciclo" dentro da obra de Lins do Rego, o que, para ele, o ensaísta não teria compreendido.

Por outro lado, Wilson Martins (p.4) pondera a análise de $O$ coronel e o lobisomem para concluir que, apesar das concepções críticas equivocadas que falseariam a visão do ensaísta gaúcho sobre a literatura brasileira, ele "acaba por descobrir a verdade essencial que as ambiciosas teorias ocultavam". Admitindo os momentos em que a análise alcançaria tal "verdade essencial", o crítico endossa a ideia utilizada por Dacanal sobre a oscilação entre o mítico-sacral e o racional como fundamentos de duas concepções de mundo verificáveis nos romances de José Cândido e Guimarães Rosa. A ressalva positiva, no entanto, dura pouco: logo em seguida, Martins reafirma sua condenação, de um modo geral, àqueles que se deixam seduzir pelas "invocações encantatórias" das linhas teóricas então vigentes (referindo-se a Lukács, Adorno e o formalismo russo), e encerra sua resenha numa comparação, pode-se dizer, um tanto ríspida:

Bem entendido, nada substitui a argúcia crítica - e os praticantes da crítica por analogia muitas vezes lembram os perdigueiros sem faro, que correm nervosamente pelo campo, erguem o rabo, espiam argutamente pelas moitas - e jamais erguem a caça. (p.4)

Wilson Martins, dois meses antes de publicar essa resenha, escrevera, em junho de 1971, um artigo sobre o romance de José Cândido, intitulado "O personagem quixotesco", no qual desenvolve algumas ideias presentes em ensaios anteriores, "Uma obra-prima", de 1964, já aqui comentado, e "Romance urbano”, de 1968. Faz-se 
pertinente resgatar algumas das considerações do crítico expressas nesses textos a fim de compreender suas contribuições à leitura do romance, bem como as razões de sua discordância em relação às ideias de Dacanal.

No artigo de 1964, em linhas gerais, Wilson Martins (1964, p.2) afirmava que $O$ coronel e o lobisomem se tratava de um romance urbano, e que a realidade nele expressa se construía em vários "planos verticais" (profundos, portanto), em contraposição aos planos horizontais (rasos, sem densidade) do romance regionalista. Além disso, o crítico já relacionava Ponciano a Dom Quixote, pela "loucura poética" e seus "duros combates imaginários contra onças e lobisomens”. No artigo de 1968, no entanto, Martins apresenta outra perspectiva quanto à vinculação da obra do campista ao regionalismo: romance urbano seria, dessa vez, um livro de Ignácio de Loyola Brandão, que na ocasião o crítico resenhava; enquanto que os romances de José Cândido e Mário Palmério, mencionados de passagem como obras de outra tendência, configurariam o "regionalismo estético", ou ainda, "regionalismo tratado como matéria estética (e não mais sociológica ou pitoresca)" (1968, p.4). O coronel e o lobisomem, então, em quatro anos, deixa de ser "urbano" e passa a ser "regionalista" com tratamento estético. Assim, localizando agora a obra no outro grupo, o crítico salienta a oposição dessas tendências não sem reiterar sua acusação, já feita no texto de 1964 ao romance de Guimarães Rosa, que padeceria, segundo ele, de certo desequilíbrio entre o plano linguístico e o "propriamente romanesco":

Todo o problema estava em obter equilíbrio entre a matéria e a forma [...]. Se em Guimarães Rosa o desnível entre esses dois valores é inegável e visível, em Mário Palmério e José Cândido de Carvalho deparamos ao contrário, com a arte das perspectivas e com o sentido da unidade levadas ao seu ponto extremo de perfeição; ao lado desse "regionalismo estético", o romance urbano de Ignácio de Loyola mostraria o seu caminho de uma arte romanesca incrustada no seu tempo e recriando o espaço nos planos do imaginário. (Martins, W., 1964, p.2) 
É, por sua vez, no ensaio "O personagem quixotesco", de 1971, que Wilson Martins desenvolve com maior depuro suas ideias sobre o romance $O$ coronel e o lobisomem, sendo, certamente, apesar de possíveis pontos frágeis, o mais acurado de seus textos sobre a obra. A seguir, transcrevem-se alguns trechos do ensaio que, embora um tanto longos, dão destaque para pontos relevantes sobre o que se vem aqui discutindo:

A releitura, sete anos depois, de $O$ coronel e o lobisomem torna incontestável que José Cândido de Carvalho escreveu efetivamente uma daquelas obras-primas do romance que atravessam os tempos e acrescentam uma dimensão nova à literatura existente. [...] Ele criou um tipo romanesco e um estilo; e tendo, igualmente, elevado a matéria regionalista, do plano do pitoresco ou documentário, ao plano da invenção estética, consolidou a renovação de uma espécie literária que Guimarães Rosa e Mário Palmério (ambos em 1956) já haviam iniciado. É nessas perspectivas, creio eu, que deve ser lido e relido O coronel e o lobisomem; e, se é certo que Guimarães Rosa não só mostrou o caminho, mas também até onde é possível usá-lo para ir longe demais, é da mesma forma verdade que Mário Palmério e José Cândido de Carvalho restabelecem o equilíbrio de composição que é a primeira condição da obra-prima - a sua condição essencial. [...] Em O coronel e o lobisomem [...] a qualidade mais alta, ao nível da realização, está na profunda identidade entre o personagem e o estilo da narrativa; entre o estilo propriamente dito e a natureza da história; entre esses dois elementos e o coronel Ponciano enquanto tipo romanesco. (Martins, 1971, p.4, grifo nosso)

Observe-se que, ainda nesse texto, Martins (p.4) aceita a filiação de José Cândido, mesmo que longínqua, ao romance nordestino, mas dessa tendência o autor se afastaria pelo investimento no aproveitamento ficcional do fato documental e pela maior complexidade concedida à figura humana, fatores que marcariam um novo momento da prosa regionalista: 
O que esse livro veio afinal demonstrar (contra os princípios do romance "nordestino" e "social" de que provém longinquamente o autor) é que, além de ser, por definição, indiferente à criação literária, o documento só pode servi-la e servir-lhe na medida em que for inventado, quero dizer, submetido ao processo de ficcionalização sem o qual existem fatos, mas não literatura; assim, a verdadeira decadência da sociedade patriarcal não ocorre pelos sucessivos desaparecimentos do bangue em face do engenho, [.... mas pela decomposição psicológica de um universo mental, pela transformação sutil, mas irreparável e inevitável, dos valores e das crenças. Por isso, há, na realidade como na literatura um processo característico de "quixotização" dos tipos que realmente representavam as crenças e os valores de uma determinada sociedade quando sobrevivem o suficiente para conviver com a sociedade seguinte. O Quixote é, no fundo, um saudosista e um desesperado; [...] José Cândido de Carvalho criou, a exemplo de Cervantes, a figura pungente, não do louco, como se pensa e escreve, mas do homem sensível que se vê desaparecer o seu mundo - e, antes de mais nada, o seu mundo espiritual - diante da invasão dos bárbaros.

[...] O que importa, na figura do Quixote, não são os fatos, mas a significação; no romance, os fatos representam-se pelas peripécias da intriga, e a significação pela natureza profunda do personagem. Percebe-se agora que a diferença essencial entre o romance "nordestino" e o de José Cândido de Carvalho, entre os cangaceiros da ficção propriamente regionalista e os de Guimarães Rosa e Mário Palmério, está em que, no primeiro caso, o romancista se preocupava com os fatos, e, no segundo, com a significação do personagem. Em Grande sertão, o que importa, na verdade, não é o cangaço, mas o sentido do cangaço na grande máquina do mundo; [...] em $O$ coronel e o lobisomem, é o lento esfarelamento de um quadro de valores que a crença no abantesma simboliza de maneira perfeita. O coronel, visto como figura social, não é anacrônico por ser um patriarca nas suas fazendas, mas por acreditar em almas do outro mundo: ele é coronel porque acredita no lobisomem. [...] não é o fato de acreditar no lobisomem o que importa; o que realmente conta é que toda a vida 
social, com seus valores próprios, materiais e cotidianos, esteja organizada em torno do lobisomem como uma constelação nas linhas ideais do seu desenho.

Ora, para transmitir eficientemente, em termos literários essa realidade, José Cândido de Carvalho descobriu instintivamente que lhe era necessário inverter o grande postulado estético dos anos 30 (a que ele próprio havia sucumbido, em 1939, com Olha para o céu, Frederico!): trata-se agora de escrever com o máximo de literatura e o mínimo de realidade. (p.4, grifo do autor)

Diante do exposto, é possível perceber que as perspectivas de José Hildebrando Dacanal (1970) e Wilson Martins (1971) convergem para um mesmo sentido no que concerne à percepção de um distanciamento entre o romance de José Cândido e a prosa dos anos 1930, bem como no que diz respeito ao reconhecimento, por ambos os críticos, de um processo irreversível de desaparecimento do universo de valores e crenças do protagonista. Por outro lado, as referências a Dom Quixote atendem a propósitos e pontos de vista distintos em cada texto. Assim, enquanto Martins resgata o livro de Cervantes para afirmar a semelhança entre a composição de Quixote e Ponciano, Dacanal o menciona como modo de exemplificar obras modelares da consciência dessacralizada e da perspectiva racionalista, traços determinantes de toda uma tradição da ficção ocidental e dos quais os romances do ciclo latino-americano se afastariam. Para o crítico gaúcho (Dacanal, 1970, p.11), o romance de Cervantes trabalharia "o mágico ou o fantástico" a partir de um viés racionalista, atribuindo-os à anormalidade do herói. Em outras palavras, os fatos inverossímeis ou insólitos no romance cervantino seriam explicados pela perturbação psicológica do protagonista. E seria por afastar-se dessa consciência racionalista que $O$ coronel e o lobisomem, ao lado de outras obras da literatura latino-americana, conformaria um evento novo na prosa ficcional.

Embora as duas perspectivas divirjam pelas motivações com que convocam o romance de Cervantes às suas análises, considerando-se o fato de Dacanal defender que o romance $O$ coronel e o lobisomem 
manifesta uma consciência mítico-sacral, é preciso admitir que seu ponto de vista não se afasta tanto do expresso por Wilson Martins, quando este sustenta que a visão de mundo de Ponciano (sua consciência mítico-sacral, como preferiria Dacanal) é a que determina a visão do leitor:

[... pode-se aduzir que o ritmo estilístico é o próprio Ponciano, o sistema de imagens, as figuras e a visão de mundo que o romancista nos comunica por intermédio e através das palavras: a nossa visão do mundo é a de Ponciano, o que explica a imediata cumplicidade ativa que se estabelece entre o leitor e o personagem. (Martins, 1971, p.4, grifo nosso)

A confluência desse raciocínio é assegurada, deve-se lembrar, pelo próprio Wilson Martins quando, ao resenhar o livro de Dacanal, endossa o argumento da existência da tensão entre o mítico-sacral e o lógico-racional, que estaria presente no romance de José Cândido e Guimarães Rosa. A respeito desse jogo de forças opostas, apresentado por Dacanal em 1970 e legitimado por Martins em 1971, é preciso lembrar que fora Antonio Candido quem primeiro o reconhecera e o apontara como princípio presente em Grande sertão: veredas, no ensaio "O homem dos avessos". Em 1957, Candido, portanto, já sentenciava sobre o romance de Rosa: "Nesta obra combinam-se o mito e o logos, o mundo da fabulação literária e o da interpretação racional, que disputam a mente de Riobaldo, nutrem a sua introspecção tacteante e extravasam sobre o Sertão" (1978, p.139).

Seja ou não em função das críticas de Wilson Martins, fato é que José Hildebrando Dacanal republica seu ensaio sobre O coronel e o lobisomem, em 1973, sob a denominação "As contradições do coronel”, como parte do livro Nova narrativa épica no Brasil. ${ }^{10}$ Do livro Realismo mágico, de 1970, esse é o único ensaio que o crítico aproveita, pois

10 Utiliza-se aqui a segunda edição do livro Nova narrativa épica no Brasil, publicada em 1988. Segundo o autor, em prefácio, essa edição mantém quase inalterado o texto da primeira, acrescida apenas de um ensaio sobre Os guaianãs, de Benito Barreto. 
enquanto a análise de Fogo morto, atacada por Martins, é excluída, a de Grande sertão: veredas é completamente reformulada e ampliada. O livro traz ainda um estudo sobre o romance Sargento Getúlio, de João Ubaldo Ribeiro. Comentários sobre a obra Cem anos de solidão, de García Márquez, são situados como apêndice do livro. Todas as obras analisadas aparecem agora não mais sob o rótulo do realismo mágico, mas classificadas como representantes da categoria que o crítico denomina "nova narrativa épica latino-americana". Essa classificação por ele desenvolvida é justificada no interior do ensaio sobre Grande sertão: veredas ("A epopeia de Riobaldo"), texto que ocupa mais da metade do livro. Nele, o crítico aprofunda e esclarece questões levantadas nas análises que compunham o livro de 1970.

O novo modo de designar o fenômeno que visualiza na literatura latino-americana é bastante expressivo de uma reformulação de conceitos por parte do autor, talvez motivada pelas críticas que recebeu. Quanto ao ensaio sobre o romance de José Cândido de Carvalho, em específico, além do novo título, notam-se também algumas pequenas alterações no corpo do texto em relação à primeira versão, aliás, modificações indicativas do reconhecimento posterior, por parte do crítico, da fragilidade de certos pontos de sua análise, como alguns dos aqui questionados. Nesse sentido, considerando-se os problemas identificados, merece atenção especialmente a mudança de um vocábulo: o crítico (Dacanal, 1970, p.36) afirmava, no ensaio de 1970, que Grande sertão: veredas criava algo de novo na ficção nacional, que até o momento permanecia dividida em dois planos: "o regionalista e o urbano"; nas novas versões do ensaio, no entanto, o par é alterado para “o agrário e o urbano” (Dacanal, 1988, p.85). E não só isso: em Era uma vez a literatura, publicação de 1995 em que retoma essas questões, o crítico repudia, explicitamente, a utilização do termo regionalismo, ao afirmar que os romances analisados

[...] representam um grupo mais ou menos isolado dentro da ficção brasileira desta segunda metade do século. Isolado ou característico em primeiro lugar por serem de temática agrária - não me fale em regional ou regionalista! Em segundo lugar por fixarem o mundo do 
sertão, o mundo da cultura caboclo-sertaneja, isto é, as sociedades interioranas distantes da costa. [...] eu chamei de nova narrativa épica brasileira as obras que fixam estes mundos interioranos, muito marcados pela cultura ibérica, não influenciados, pelo menos não de maneira considerável, pela visão de mundo lógico-racional da cultura europeia anglo-francesa da era pós-Independência. São obras em que a ação épica, no sentido hegeliano do termo, está presente. Quer dizer, não há nestas obras um distanciamento entre o herói e o mundo. Existe, de fato, um conflito de visões de mundo, mas acima disto está a ação de heróis que se movimentam e agem num contexto cultural mítico-sacral. Ou pré-lógico-racional. (Dacanal apud Pires, 2008, p.52)

Dacanal substitui ainda o conceito de "realismo mágico" por "nova narrativa épica latino-americana" e elimina algumas das aparições do termo "fantástico". Outro ponto que o crítico reconsidera na republicação do ensaio refere-se ao momento em que nega a importância da dimensão representacional de um plano sócio-histórico em Grande sertão: veredas. Em lugar de reformular a ideia, Dacanal acrescenta uma nota de rodapé que acaba por tentar indiretamente justificar as demais imprecisões e inconsistências de sua análise: "Evidentemente, esta fluidez e esta idealização em Grande sertão: veredas não são tão absolutas assim. Credite-se tal afirmação a uma certa ingenuidade do autor à época da redação deste ensaio" (Dacanal, 1988, p.81, grifos do autor).

De qualquer modo, o que há de mais significativo nessa publicação é o desenvolvimento de sua proposta sobre o que seria a "nova narrativa épica latino-americana" ${ }^{11} \mathrm{Na}$ parte introdutória do ensaio "A epopeia de Riobaldo", Dacanal esclarece que seus fundamentos teóricos partem das ideias de Hegel, em Lições de Estética,

11 Além disso, Dacanal (1988) utiliza a expressão "nova narrativa épica latino-americana”, sem conceder os devidos créditos - provavelmente por desconhecimento - a Arturo Torres-Rioseco (1897-1971), crítico chileno e professor de literatura latino-americana nos Estados Unidos, que já a utilizara anteriormente no livro The Epic of Latin American Literature, cuja primeira edição é de 1942. 
e de Lukács, em Teoria do romance. A justificativa para o uso desse instrumental teórico é a de que esses estudiosos teriam captado "as coordenadas históricas dentro das quais surgiu e desapareceu o romance” (1988, p.19). Mas a convocação desses autores à reflexão levou o crítico a esquematizações e simplificações certamente prejudiciais às premissas de seu raciocínio. Sabe-se que, apesar dos pontos de contato, as formulações do filósofo alemão e as do pensador marxista húngaro chocam-se em questões fundamentais quanto à concepção que possuem do romance. Conforme explica Letizia Zini Antunes (1998), Lukács aceita e adota a proposição de Hegel, segundo a qual o romance é produto literário típico da sociedade burguesa e, por isso, expressa uma cisão fundamental entre o eu e o mundo. No entanto, o pensador húngaro discorda da ideia de que o romance deva indicar um caminho de reconciliação entre o indivíduo e o mundo, tal como acredita Hegel. Para Lukács, ao contrário, essa reconciliação seria impossível. Além disso, para ele, Hegel não teria percebido que a oposição entre o indivíduo e a sociedade teria por base a contradição essencial do modo de produção capitalista, pelo conflito entre as classes burguesa e proletária. Partidário da ideologia marxista, Lukács acreditava na superação da sociedade capitalista para um novo e superior modelo de produção.

Não bastasse tais divergências entre os autores, ignoradas ou pelo menos não mencionadas por Dacanal, o próprio Lukács (Antunes, 1998) incorreria em contradição, pois, apesar de ter defendido que as produções literárias devessem ser analisadas em vista das conjunturas sócio-históricas em que surgem, pratica, posteriormente, análises em que desconsidera os novos contextos de formação das obras, analisando-as por meio de parâmetros anacrônicos, úteis a obras de momento histórico anterior. Com isso, foi acusado de não ter compreendido e, consequentemente, de menosprezar obras do século XX, como as de Joyce, Proust e Kafka, uma vez que as analisava pautando-se em critérios estéticos pensados originalmente para obras do realismo europeu do século XIX. Theodor Adorno (apud Antunes, 1998) é, inclusive, uma das vozes de autoridade, enquanto teórico da ficção moderna, que o ataca sob esse argumento, chegando 
a afirmar que Lukács não apenas é incapaz de distinguir romances completamente diferentes entre si, dando-lhes o mesmo tratamento, como também se mostra incapaz de perceber as diferenças existentes entre as proposições dele próprio (Adorno) e as de Walter Benjamin.

Desconsiderando essas implicações, Dacanal busca encontrar nos teóricos um ponto de partida para compreender um fenômeno que verifica em romances latino-americanos da segunda metade do século XX e situá-los frente à tradição e ao desenvolvimento da ficção ocidental. O crítico reporta-se à obra que marcou o início do romance moderno, Dom Quixote, de Cervantes, e chama a atenção para o fato de que nela já se verifica a perspectiva ficcional lógico-racionalista, marca essencial de toda a narrativa de ficção surgida posteriormente na Europa, principalmente durante a efervescência do romance do real naturalismo, entre os séculos XVIII e XIX. Seriam consequências dessa perspectiva: a busca da verossimilhança, conquistada por meio de artifícios que tornariam a história crível, verossímil (por exemplo, a história é testemunhada por alguém ou há papéis encontrados que confirmam os fatos, atestando a veracidade do relato etc.); e o consequente distanciamento de tudo que não fosse verossímil a uma consciência lógico-racional, ou seja, quando se retrata o inverossímil, o próprio narrador anuncia essa circunstância, confessando que os fatos são anormais, estranhos, criando, com isso, um efeito de distanciamento dos eventos insólitos, compactuado com a ótica racionalista do leitor. A essas histórias encontram-se, muitas vezes, explicações naturais que anulariam a anormalidade dos eventos.

No caso do romantismo alemão, retrato da desilusão diante do real, sequer chega a haver uma relação de contraposição entre o real, ou verossímil, e o irreal, ou inverossímil, uma vez que se estaria no território do maravilhoso, mundos regidos por outras leis que não as do mundo "real", ordinário. Mencionando os contos de Hoffmann, Dacanal (1988, p.14) sugere que mesmo o fantástico produzido pela literatura alemã não consegue, apesar dos esforços, "colocar lado a lado o verossímil e o inverossímil", revelando ser impossível a criação de mundos não regidos pela logicidade e pelo racionalismo. 
Isso ocorreria, por exemplo, quando a história insólita termina por se insinuar como ficção alegórica ou simbólica, pois, nesses casos, o evento incomum deixa de sê-lo, para apenas representar uma outra matéria. Processo semelhante se daria com outras obras europeias, como as satíricas de Swift, Rabelais e Voltaire, além de romances alegóricos, como os de Melville, Wilde e Balzac.

Saltando ao romance latino-americano da segunda metade do século XX, a "nova narrativa épica latino-americana" configuraria, segundo Dacanal, uma ruptura na diretriz da continuidade racionalista, cuja norma era o distanciamento. Essa nova configuração assumida pelo romance colocaria "lado a lado, de forma inocente, sem distanciamento, o mundo real, verossímil, e o mundo mítico-sacral, inverossímil", incorporando "elementos integrantes de estruturas conscienciais completamente diversas daquelas que informaram [...] a ficção ocidental" (Dacanal, 1988, p.15, grifos do autor). Por essa razão, o autor defende que seria preciso, para compreender essa nova produção literária, ignorar as categorias críticas criadas "em um e para um outro mundo ficcional".

Na sequência, o crítico apresenta as razões da utilização do conceito de épico em sua formulação. Recorrendo a Hegel e Lukács, perpassa os três momentos em que a épica teria se manifestado: primeiramente, a épica propriamente dita, o epos grego; em segundo lugar, a produção da era medieval; e, por último, o romance da moderna idade burguesa europeia. Embora em cada uma dessas etapas o conceito adquira uma nuance própria, decorrente dos diferentes universos de valores e estruturas de pensamento de cada era, o termo, em todos os casos, evocaria a narração da ação do homem sobre o mundo. O crítico vale-se, então, da ideia hegeliana, reproduzida em muitos aspectos por Lukács, de que o romance europeu corresponderia à epopeia burguesa, cujo objeto seria a realidade tornada prosaica. Depois de insinuar, aludindo com imprecisão, a divergência conceitual entre os autores a respeito da constituição do romance, Dacanal, elogiando a primeira parte de Teoria do romance, de Lukács, afirma: 
O que Hegel esboça sumariamente, sem alcançar plena clareza, Lukács retrabalha e amplia: a caracterização e o enquadramento definitivos do romance como forma do que se poderia chamar de um novo gênero épico e como único fenômeno literário possível de ser, com propriedade, assim qualificado, ao lado do epos grego, por ser um mundo completo em si próprio, completo mesmo em sua intrínseca problematicidade.

$[\ldots]$

Depois dele [de Lukács] não será mais possível esquecer - sob pena de não se entender nada - que o romance europeu é realmente a epopeia de "um mundo sem deuses", dessacralizado, onde todos os valores são relativos e onde esta relativização é, paradoxalmente, a própria plenitude. Um mundo estilhaçado, órfão de um centro catalisador ou, melhor, mundo cuja própria unidade é a de não possuí-la. (Dacanal, 1988, p.17-8)

O romance do real-naturalismo, representando um mundo dessacralizado (sem deuses), seria a forma de expressão artística própria da idade burguesa, em sua perspectiva ficcional lógico-racionalista. A Primeira Guerra Mundial, no entanto, teria significado um momento de desintegração da idade burguesa europeia e, por consequência, a "crise do romance" (p.18), sua principal forma de expressão artística. Assim, Dacanal afirma que, a partir disso, embora a narrativa ainda possa existir na Europa, o "romance europeu", compreendido nesses padrões, teria definitivamente desaparecido. Dessa forma, o crítico esclarece que Hegel e Lukács importam para a análise de uma obra da "nova narrativa latino-americana" na medida em que ambos conseguiram captar as diretrizes históricas em que o romance teria surgido, se desenvolvido e desaparecido, percebendo a estrutura de consciência laicizada, dessacralizada do mundo europeu:

[... por terem desvelado o essencial, esclarecem, por contraposição, a especificidade de uma obra nascida dentro de outras coordenadas históricas. [...] Ora, a nova narrativa épica latino-americana é, para 
mim, um outro tema, um terminus comparationis, inexistente até então, para o romance europeu. (p.19)

Por essa razão, para o crítico, uma obra como Grande sertão: veredas integraria, se não um novo gênero literário, ao menos uma nova forma de narrativa épica, novo momento possuidor de uma essencialidade própria, surgida dentro de coordenadas históricas específicas, diferentes das que informaram o romance europeu. Desse modo, por representar um "corte na narrativa ocidental", esse novo momento estético exigiria uma análise que partisse dele próprio, sem recorrer ao romance real-naturalista europeu, que já estaria superado. É também nesse sentido, para não evocar indesejadamente a narrativa europeia, que o crítico explica preferir a denominação "narrativa épica" a utilizar o terminologia "novo romance", que poderia remeter à configuração específica do nouveau roman europeu.

Antes de prosseguir com os outros esclarecimentos de ordem teórica, por meio dos quais o crítico busca amparar sua perspectiva de análise, faz-se forçoso destacar um ponto que emerge de modo bastante problemático em sua proposição. Na verdade, trata-se de uma questão que salta aos olhos justamente por estar ausente de sua abordagem ou, ainda, por sua "despresença", como diria Ponciano. Ao recuar à construção de toda uma tradição da narrativa europeia, buscando elaborar, ambiciosamente, um raciocínio teleológico que permitisse, ao final, situar a produção romanesca brasileira e latino-americana da segunda metade do século XX na literatura do ocidente, Dacanal atropela um evento fundamental à compreensão do fenômeno que busca explicar: não se encontra, em seu horizonte de reflexão, qualquer menção ao papel que as vanguardas europeias poderiam desempenhar diante desse panorama. A despeito da proximidade histórica das manifestações vanguardistas ao momento estético que procura decifrar, o crítico simplesmente se abstém de qualquer esforço para afirmar ou mesmo recusar suas possíveis implicações no processo de ruptura instaurado pela literatura latino-americana na tradição da narrativa ocidental. As vanguardas impuseram-se como contraponto à tradição da narrativa do realismo 
europeu. Procuraram questionar, transgredir, romper, opor-se a todo o legado de racionalidade decorrente do utilitarismo burguês.

O surrealismo, por exemplo, apresenta uma proposta que, apesar das peculiaridades, partilha de alguns dos aspectos apontados por Dacanal ao definir a "nova narrativa épica". Segundo Peter Bürger (2012, p.120-2), em Teoria da vanguarda,

Partindo da experiência de que uma sociedade ordenada segundo a racionalidade-voltada-para-os-fins limita cada vez mais as possibilidades de desdobramentos do indivíduo, os surrealistas procuraram descobrir momentos do imprevisível na vida cotidiana. Sua atenção, por conseguinte, se dirige para os fenômenos que não têm lugar num mundo ordenado segundo essa racionalidade-voltada-para-os-fins. A descoberta do maravilhoso no cotidiano representa, sem dúvida, um enriquecimento das possibilidades de experiência do "homem-urbano"; mas ela se acha ligada a um tipo de comportamento que renuncia a toda e qualquer planificação em favor de uma receptibilidade integral às impressões. No entanto, os surrealistas não se dão por satisfeitos - eles buscam provocar o extraordinário. A fixação em determinados lugares (lieux sacrés) e o esforço em torno de uma mythologie moderne indicam que, para eles, se trata de dominar o acaso, tornar receptível o extraordinário.

$[\ldots]$

Não está sendo criticado o objetivo determinado, o lucro enquanto princípio que domina a sociedade capitalista-burguesa, mas a racionalidade-voltada-para-os-fins.

A exclusão das vanguardas pelo crítico gaúcho, fato que se poderia tentar justificar em razão de uma busca exclusiva pela manifestação do épico na literatura, não parece medida defensável. Uma possível motivação, condizente com a perspectiva teórica adotada, pode advir da adoção quase irrestrita da perspectiva de Lukács, ao igualmente desconsiderar o valor e importância das manifestações vanguardistas, tomando como modelos de arte os modelos do realismo. Ignorar esse novo momento da produção artística europeia, 
com o qual se nutriram - antropofagicamente - muitos escritores, inclusive brasileiros, significa certamente pular um episódio crucial para a compreensão das inovações que se verificam posteriormente no continente latino-americano. De qualquer modo, deve-se reconhecer que tal salto acaba por corresponder a um modo, deliberado ou não, de "aparar arestas", eliminando pontos indesejados que poderiam desestabilizar a unidade e o caráter superficial e esquemático de seu raciocínio.

Ainda no ensaio "A epopeia de Riobaldo", em seu segundo tópico, o crítico procura explicar o sentido com que utiliza o binômio mítico-sacral, recorrente em sua explanação. Primeiramente, o ensaísta lembra que os conceitos utilizados no âmbito literário devem encontrar, nesse mesmo âmbito, seu sentido e definição. Assim, a utilização do conceito mítico-sacral nos limites da "nova narrativa épica latino-americana" deveriam ainda ser discutidos e fixados. $\mathrm{O}$ autor busca ainda desvincular do uso que faz dessa terminologia os estudos antropológicos de Lévi-Strauss, os estudos dos mitos de Mircea Eliade e também o campo das pesquisas sobre o inconsciente, de Freud, Jung e Reich. No entanto, admite a viabilidade de ampliar a utilização do termo a esses terrenos, a fim de reconhecer fenômenos literários semelhantes ou idênticos aos percebidos na "nova narrativa épica".

A concepção de mítico-sacral em suas análises estaria ligada, nesse sentido, à definição de uma estrutura de consciência, em outras palavras, uma forma do homem ver o mundo que o cerca, de interpretar o real. A consciência, por sua vez, seria a capacidade do indivíduo isolado de ordenar o real dentro das coordenadas próprias às estruturas de captação do real, estruturas estas que lhe são dadas pela sociedade na qual nasceu e viveu e por sua experiência existencial. Assim, uma estrutura de consciência mítico-sacral seria a forma por meio da qual um indivíduo, como parte de um grupo, capta e interpreta os "fenômenos cuja epifania presencia" (Dacanal, 1988, p.41). Essa captação da realidade para esse tipo de consciência ocorreria de modo oposto ao da consciência lógico-racional. Para esta, a captação dos fenômenos ocorreria apenas na dimensão da objetividade 
- o mundo exterior existe e é interpretado na medida em que possui objetividade empírica ou lógica -, enquanto que, para a consciência mítico-sacral, é possível aceitar como existentes entidades que não possuam tal existência empírica ou lógica. Na evolução histórica dos grupos humanos, a consciência mítico-sacral antecederia a lógica-racional, mas se manifestaria ainda em grupos isolados como os indígenas e populações que se mantiveram afastadas da civilização, "grupos humanos localizados no hinterland latino-americano e que, agora, inesperadamente, passaram a integrar novamente o processo histórico manifestando sua vitalidade em criações artísticas de extremo vigor [...]" (Dacanal, 1988, p.43).

Tendo utilizado a denominação lógico-racional para definir a estrutura de consciência presente na ficção do real-naturalismo, Dacanal conjectura quais seriam as possibilidades terminológicas adequadas para definir o modelo de ficção que a esse se oporia, elegendo como viáveis os termos "mágico", "mítico", "sacral” e "mítico-sacral". O primeiro deles, no entanto, é descartado sob as justificativas de ser demasiadamente fluido e de sua aplicação ser pouco tradicional no âmbito literário; por outro lado, "realismo mágico" seria uma expressão conveniente, já que, apesar da redundância, aludiria, por oposição, ao realismo realista. Já termos consagrados e com limites mais claros seriam "mítico" e "sacral": o primeiro teria sentido mais ou menos unívoco nos campos da antropologia, da história das religiões e da filosofia, enquanto o segundo adquiriria sentido no plano teológico. Mas Dacanal (1988, p.44) afirma que essas concepções isoladas não interessam a seu tipo de análise:

Assim, optou-se pelo termo híbrido mítico-sacral. Contra esta opção poder-se-ia argumentar que a razão de sua escolha talvez tenha sido sua pouca clareza. Até certo ponto a objeção é correta. Quando um termo ou expressão não carrega um sentido definido e consagrado pode-se, com facilidade, atribuir-lhe um. Se os termos mítico e sacral isolados possuíam viabilidade relativa mas exigiam uma redefinição cuidadosa, podemos juntá-los e dar-lhes viabilidade, simplesmente. 
A despeito da arbitrariedade de muitas de suas afirmações, como ocorre com a justificativa acima e outras enunciadas, Dacanal, tendo publicado essa pequena coletânea de ensaios em 1973, ampliando a discussão iniciada em 1970, certamente contribuiu, a seu modo, à construção de uma perspectiva de análise para o romance de José Cândido de Carvalho e para obras de outros autores latino-americanos. Embora os meios pelos quais busca sustentar seu ponto de vista sejam, por vezes, falhos, lacunares, contraditórios, deve-se reconhecer seu esforço e coragem para tocar em questões espinhosas em vista dos limites de atuação de uma crítica literária brasileira que apenas começava a demonstrar interesse pelo diálogo das letras nacionais com a literatura hispano-americana.

Dado o reconhecimento às compilações ensaísticas de Dacanal, não se pode esquecer que a crítica cultivada nos jornais já vinha promovendo a reflexão sobre a literatura brasileira e a literatura dos demais países latino-americanos. Assis Brasil publicara, por exemplo, em 27 de dezembro de 1969, um artigo intitulado "Nós temos melhor", no caderno Arte e Crítica do jornal O Globo. Nesse texto, o escritor e crítico literário comenta o sucesso do lançamento de Cem anos de solidão no Brasil, lembrando, no entanto, que a literatura nacional já produzira obras tão ou até mais inovadoras que a do colombiano, nesse segmento literário conhecido por promover a ruptura com o realismo convencional. Porém, Assis Brasil (1969, p.9) lembra que nossos romances do gênero permaneciam, até então, no "limbo editorial e promocional". De fato, O coronel e o lobisomem, romance que ele menciona ao longo do artigo comparando a Cem anos de solidão, ainda estava em sua segunda edição, portanto, sem muita visibilidade:

Os nossos possíveis best-sellers - digo os de nível literário - ainda estão no limbo editorial e promocional. Gabriel García Márquez poderia agora deflagrar uma corrida ao livro de $O$ coronel e o lobisomem, de José Cândido de Carvalho, por exemplo, de que é irmão em técnica e concepção. Mas os brasileiros, ainda com aquele velho espírito colonialista, aceitam de olhos fechados o que vem de fora, 
dizem amém e logo concordam que com alguns apressados de que nada de igual temos em nossa literatura. (Brasil, 1969, p.9)

Inflamado em seu afã nacionalista, Assis Brasil (1969, p.9) no mesmo artigo compara o protagonista de $O$ coronel e o lobisomem com o de Cem anos de solidão, para declarar a superioridade do brasileiro:

Dizem os neófitos e os críticos de segunda categoria que Cem anos de solidão abandona o realismo e rompe a fronteira do natural com o sobrenatural. E daí? E argumentam que na literatura brasileira não há nada igual. Claro que há o melhor. Já nos referimos ao Coronel e o lobisomem, de José Cândido de Carvalho - o personagem deste romance deixa o velho Buendía no chinelo. E José Cândido faz mais, faz uma linguagem para mostrar aquele mundo de fábulas, lendas e mitos.

Sobre essa comparação entre as personagens, o próprio José Cândido se manifestou em entrevista dizendo que em comum com o protagonista de Cem anos de solidão, Ponciano era feito "de sonhos" e tinha "os pés na terra". Assis Brasil também refere-se ao realismo mágico para situar a obra de José Cândido em um grupo de escritores brasileiros, e salienta que isso não elimina o caráter combativo e de denúncia dos problemas sociais que permeiam a narrativa:

O certo é que a literatura de ficção no Brasil, nos últimos dez anos, já abandonou o realismo por uma espécie de realismo mágico, onde no entanto os problemas sociais e as injustiças continuam a ser denunciados com a mesma veemência de um documento sociológico. Citemos José Cândido, e um pouco para trás Adonias Filho, e mais Clarice Lispector, Guimarães Rosa, e os mais novos, Autran Dourado, Osman Lins, e os novíssimos José J. Veiga, José Edson Gomes, Jorge Mautner, Rubem Fonseca e inúmeros outros. (Brasil, 1969, p.9) 
A tendência da crítica em relacionar o romance $O$ coronel $e$ o lobisomem ao realismo mágico parece ter se estabelecido quase desde o surgimento da obra: em 1966, na solenidade de entrega do prêmio Coelho Neto da ABL a José Cândido de Carvalho, Josué Montello declara que o livro é da mais alta qualidade literária e afirma: "estamos em face de uma espécie de realismo mágico, em que as qualidades de observação se conjugam naturalmente com a força da invenção como que inconsistente do narrador palrador" (Jornal do Brasil, 30 jun. 1966, $1^{\circ}$ Caderno, p.14). Essas apreciações demonstram, portanto, que o uso do termo se consolidou desde cedo e tornou-se corrente na fortuna crítica de José Cândido, fato em conformidade com o período do boom latino-americano.

Regina Zilberman (1977) notou também a proximidade desse fenômeno da literatura brasileira ao que acontecia na ficção dos demais países da América Latina e defendia, assim como Assis Brasil, a necessidade de pensar conjuntamente a faceta mítica da obra e seu plano de fundo sócio-histórico. A autora do livro Do mito ao romance: tipologia da ficção brasileira contemporânea identifica um "desvio" da ficção nacional de influência europeia e um retorno a mitos indígenas e africanos. Trata-se de um momento do despertar do arcaico em sociedades a caminho da modernização. Assim, Zilberman investiga o mito e sua relação com a história, de modo que constata em alguns romances brasileiros, entre os quais $O$ coronel e o lobisomem, a conjunção da modernidade com o maravilhoso e o extraordinário. Para tanto, a autora percorre as definições do mito em várias áreas do saber, aprofundando com rigor teórico questões levantadas por Dacanal e propondo outras, de modo a demonstrar como a literatura brasileira se vinculou à expressão mítica criando uma tipologia (código, modelo) comum a obras da época. Para ela, o maravilhoso (como o extraordinário ou o sobrenatural) é tomado como categoria literária por fazer parte do mito.

Nesse estudo, o mais completo localizado sobre a questão, Regina Zilberman inicia sua reflexão lembrando que a história da literatura brasileira corresponde, desde o Romantismo, a uma busca de identidade, no sentido da afirmação de valores nacionais em oposição às 
importações estrangeiras. $\mathrm{O}$ mesmo teria se passado com as demais literaturas latino-americanas, oriundas também de uma condição de subdesenvolvimento e ainda servis ao estatuto colonial, na medida em que dependem de outros países mais poderosos política e economicamente. Essa procura teria levado os escritores hispano-americanos à descoberta e valorização do repertório mitológico próprio dos indígenas, primeiros habitantes do continente, e das populações advindas da colonização, com destaque para a contribuição negra, cultura rica em primitividade e magia. Esses acervos culturais de índios e negros, fundidos ou não com o elemento branco, tornaram-se, segundo a autora (1977, p.15), "a fonte mais importante para a criação de uma nova arte literária, [...] marcada pela presença do maravilhoso", e caberia ao romance explorar tais recursos.

Como o aproveitamento da mitologia também ocorre na literatura europeia, a autora esclarece, endossando o pensamento de Carpentier, que se trata de fenômenos distintos: no caso da América Latina, o caudal mitológico decorre da formação étnica específica do continente, resultado da fusão entre os povos conquistadores, conquistados e transplantados. Além disso, a permanente reelaboração dos mitos da Antiguidade ou dos mitos bíblicos pelas literaturas europeia e norte-americana não configura um programa literário que particularize um grupo de autores e obras concomitantes em países distintos, utilizando-se de um procedimento artístico comum.

Para explicar o caso nacional, Zilberman recorre à sistematização de Darcy Ribeiro (2007), segundo a qual o povo brasileiro - ao lado dos chilenos, venezuelanos e colombianos - integra o grupo dos "Povos novos", populações caracterizadas pelo cruzamento das três raças formadoras da nacionalidade latino-americana. Esse caso difere dos "Povos transplantados", argentinos e uruguaios, marcados em sua formação étnica principalmente pelo influxo europeu, e dos "Povos-testemunho", como mexicanos e peruanos, oriundos das antigas civilizações do continente. Segundo a autora, a influência negra, nesse contexto, apesar da larga repercussão cultural e artística, pouco teria influenciado, salvas algumas exceções, na literatura, a arte da palavra. A partir disso, a autora constata, no entanto, que 
a narrativa brasileira posterior a 1945, vista panoramicamente, apresenta "alguns textos anômalos", por traduzirem em seu interior "uma visão mítica da realidade e da História, mostrando pontos em comum com a cosmovisão destes povos primitivos" (Zilberman, 1977, p.16). Tais textos, por essa razão, contrariariam as expectativas de uma sociedade branqueada e de destacada influência estrangeira, como seria o caso da brasileira. Nos anos 1970, essa "anomalia" ou "anormalidade" configuraria uma "corrente literária que, à sua maneira, se associa ao Real Maravilhoso hispano-americano” (Zilberman, 1977, p.16). Daí o delineamento de seu corpus e do propósito de seu estudo:

[...] a indagação das raízes deste fenômeno, descrevendo como se constitui através de textos que se singularizam ainda por outro aspecto: são os que desencadearam este procedimento, os pioneiros; isto é, O continente (de 1949), de Érico Veríssimo, Grande sertão: veredas (de 1956), de João Guimarães Rosa, O coronel e o lobisomem (de 1964), de José Cândido de Carvalho, e Um nome para matar (de 1967), de Maria Alice Barroso, são narrativas que deram vazão a tal conteúdo mitológico antes de 1970, ano chave, vale dizer, isentos de qualquer influxo alheio ou recíproco, exclusivamente pela necessidade interna de criação e vinculados a um contexto que, embora aparentemente distinto do hispano-americano, propiciou similar eclosão. Portanto, não foi a moda literária ou o sucesso de outrem que indicou aos seus autores o rumo a tomar, tanto que, antes, nunca se chegou a estabelecer uma relação entre eles, tendo suas obras sido analisadas noutra perspectiva crítica, de preferência documental e regionalista (é o caso, para ilustrar, de $O$ continente, tido como a versão romanceada da história do Rio Grande do Sul). (Zilberman, 1977, p.17, grifos da autora)

Ressalte-se que Zilberman procura marcar o distanciamento entre a abordagem por ela proposta e a perspectiva crítica "regionalista", entendida aqui como a de caráter documental. Na continuação, a autora apresenta a hipótese que constrói a partir de suas 
constatações: para ela, a literatura brasileira apresenta, a partir de 1945, "textos originais onde se verifica a presença de traços marcantes de sobrenatural e extraordinário, traços estes que desaguam na configuração de um mito cosmogônico" (Zilberman, 1977, p.17, grifos da autora). No entanto, é nesse ponto que a literatura brasileira se afastaria da hispano-americana, uma vez que naquela o aproveitamento das mitologias não decorre propriamente da cosmovisão de influência negra e indígena. Assim, enquanto na literatura hispano-americana seria representada uma problemática existencial do ser humano sob o prisma do mito oriundo das culturas que povoaram a América, numa dialética entre o antigo e o moderno, nas narrativas brasileiras, por sua vez, a preocupação estaria voltada à revelação da vigência de estruturas sociais envelhecidas, que sobrevivem somente à custa do mito. Neste caso, o elemento antigo surge como um obstáculo ao processo de modernização, cuja denúncia adquire caráter social.

Ultrapassando as limitações da abordagem de Dacanal, Regina Zilberman discorre sobre o conceito de mito, e, para tanto, ampara-se em teóricos como K. Schilling, Mircea Eliade e Lévi-Strauss. Conforme a autora, em primeiro lugar, o mito deve ser compreendido em sua vinculação ao grupo de indivíduos que o gerou, no caso, povos selvagens em estado evolutivo primitivo, que carecem (ou prescindem?) de uma ciência ou filosofia que lhes permita dominar e compreender a realidade que os cerca. Consequentemente, o mito seria uma expressão fortemente ligada à natureza e à sabedoria instintiva, diferente do pensamento filosófico, o qual implicaria um distanciamento entre o homem e aquilo que suscita a reflexão. Isso não quer dizer que os produtos culturais primitivos tenham caráter pré-racional, pois a cosmovisão selvagem seguiria, na verdade, uma lógica própria, manifestada por meio de uma apreensão racional do ambiente. A particularidade do mito estaria em emergir como "resposta às necessidades imediatas do real", enquanto que "a filosofia e a ciência, embora também úteis, dirigem-se ao estabelecimento de uma causa primeira que não é redutível a um objeto, nem vive nesta realidade, rejeitando a imanência inerente ao mito" (Zilberman, 1977, p.23). 
O mito seria, portanto, uma tentativa de explicitação do universo, anterior à religião, ou seja, uma ordenação do mundo pelo homem primitivo. Assim, o mito não seria uma ficção, uma explicação intelectual ou uma fantasia artística, mas uma "realidade viva", que domina e determina o mundo e o destino dos homens. Logo, as narrativas míticas seriam "a afirmação de uma realidade original $[. .$.$] que determina a vida, o destino e a atividade da raça$ humana" (Zilberman, 1977, p.24). E seria a narração a forma principal do mito: é por meio dela que se conta como, graças às façanhas dos seres sobrenaturais (os deuses), uma realidade veio à existência. O mito cosmogônico é "o relato de uma criação com um significado exemplar, já que mostra a ordem da vida e do mundo presente no todo ou em parte" (1977, p.24-5). Aproximando-se da proposição de Dacanal, a autora afirma que o mito está repleto de "sacralidade" e de "acontecimentos extraordinários". No entanto, a ideia do "extraordinário" deve ser relativizada nesse contexto, por se tratar de criação de um mundo pós-mitológico, já que na concepção primitiva o evento mítico se dá na natureza, sendo-lhe imanente, portanto, verídico, e não resultado de alucinação ou fantasia. Do mesmo modo, o sobrenatural é, na realidade, o natural, aquilo que está presente na natureza na concepção do homem primitivo.

Dessa forma, o mito adquire o significado de evento fabuloso (fictício) somente quando a crítica racionalista põe em questão seus valores. Antes disso, em Homero, mythos e logos são vocábulos que significam "o verbo": logos como o lado subjetivo de quem pensa e fala, oriundo do entendimento, e mythos como o factual (apesar da aparência paradoxal), como a própria História, testemunho direto do passado, presente e futuro, de modo que não se distingue o "verbo" do "ser", eliminando-se a distância entre significante e significado. A palavra (o verbo) adere ao objeto que designa: expressão e objeto expressado são uma mesma coisa. E como o mito não apenas designa, mas é o próprio ser, torna-se o princípio ordenador imóvel de um permanente presente que se repete para perpetuar. $\mathrm{O}$ mito coloca-se, portanto, fora do fluir histórico, garantindo eternamente 
o presente idêntico ao momento primordial da origem. Disso decorre o absolutismo do tempo primordial inerente ao mito.

$\mathrm{O}$ mito propõe ainda uma visão globalizante, avessa à noção de individualidade oriunda da filosofia grega, pois, como realidade sagrada, é o fundador da primitiva instituição de uma comunidade. Nela, cada um se sente indivíduo sem sair do plano social, em outras palavras, "o ser humano dilui-se no grupo, o clã, e a responsabilidade nunca é individual, mas de toda a sociedade" (Zilberman, 1977, p.26). Além disso, o todo orgânico da realidade mitológica é garantido também pela unidade entre homem e natureza: "o espaço se torna soberano, englobando o homem que o cultua e de onde provêm as forças que o governam, mas das quais paradoxalmente começa a se liberar" (p.26). Daí decorreria a "totalidade do espaço circundante", entidade autônoma, mas que precisa ser compreendida para dela se ter controle. Finalmente, enquanto sistema globalizante, o mito supõe a crença e a adoração, de modo que o homem a ele se ligue irracionalmente, pela fé que tudo justifica. E aqui aproxima-se novamente da reflexão de Dacanal. Pela crença e irracionalismo, a liberdade ausenta-se: "A segurança da existência mítico-sacral reside no fato de que me faz falta tal liberdade" (Schilling apud Zilberman, 1977, p.26). Caberia à filosofia a conquista dessa liberdade, mas também a insegurança e a solidão do individualismo, consequências do afastamento da ligação instintiva com a natureza.

Resgatando as reflexões de Lévi-Strauss sobre o pensamento selvagem, Zilberman chama a atenção ainda para o fato de que as sociedades primitivas podem ser compreendidas não apenas pelos seus comportamentos visíveis, mas principalmente pelo que a eles permanece subjacente, como uma categoria inconsciente ou uma estrutura. Nesse sentido proveniente da antropologia estrutural, o mito se apresenta como a garantia de segurança da vida coletiva, ao se manifestar como uma cosmovisão totalizante, que resolve contradições sociais infra ou superestruturais. Cumpre, portanto, a função de ideologia das sociedades primitivas, ao propor uma concepção uniforme, capaz de justificar as necessidades internas e corrigir ou dissimular os desequilíbrios de tais comunidades. Segundo a autora 
(Zilberman, 1977, p.28), “o início por excelência que o mito narra é o mundo cultural, isto é, aquele em que o homem manipula objetos por ele criados, assinalando a superação da submissão à natureza".

A autora aproxima as reflexões do antropólogo sobre o mito às do teórico Wladimir Propp sobre o conto popular (ou maravilhoso). Do ponto de vista da semiótica narrativa, ambos os gêneros seriam estruturalmente idênticos, porém se difeririam pelo conteúdo que veiculam, sendo o primeiro de natureza cosmogônica e o segundo de caráter recreativo, o que modifica a relação do homem com cada um desses objetos narrativos: "[...] enquanto não houver o vínculo sacralizado entre o indivíduo e o contorno natural expresso no relato, não existe o mito e, portanto, o objeto de análise tem caráter diferente, embora a matéria e as personagens permaneçam idênticas" (Zilberman, 1977, p.35). Assim, explica a autora, faz-se preciso verificar se as atitudes dos seres ficcionais são mediadas pelo sagrado, ou seja, se são de índole mítica. Este seria o pressuposto fundamental que distinguiria certas obras de uma tradição em que o universo interno do texto é secular e cotidiano, como seria o caso, acrescente-se, do romance convencional burguês. Na continuidade desse raciocínio, Zilberman (1977, p.37) afirma: "[...] se atestamos a presença do mito em certos romances brasileiros, torna-se imprescindível um tipo de análise que conduza à revelação das contradições que, segundo sua natureza, ele quer encobrir". É com base nesse pressuposto que a autora procura construir uma tipologia capaz de abranger os romances por ela analisados.

Os romances Grande sertão: veredas e $O$ coronel e o lobisomem são compreendidos pela autora como sagas individuais, aventuras vividas por um único indivíduo, em oposição aos demais romances mencionados, que são analisados como sagas familiares. Zilberman busca inicialmente constatar a presença do mito nos romances de Rosa e José Cândido, apontamentos que realiza isoladamente.

Em linhas gerais, sobre o primeiro, afirma-se que a noção de sertão assinala a primazia do espaço na narrativa. O espaço geográfico habitado pelo herói Riobaldo caracteriza-se pela presença de um modo de vida semifeudal, pautado nas relações entre o pequeno e 
o grande proprietário de terras e mantido pelo "atraso cultural" e uso da violência (Zilberman, 1977, p.95). A definição de sertão no romance deixa de designar uma parte de um todo para significar a totalidade, equiparando-se à dimensão do mundo. O segundo modo a exprimir a totalidade da natureza encontra-se na inexistência de limites que separem o real do sobrenatural, o que equivale à penetração do real por seres extraordinários, como as duas grandes entidades de Deus e do Demônio que povoam os espaços e se impõem ao homem. Essa cisão entre os polos positivo e negativo no plano das divindades repercute sobre o plano humano, na medida em que se reconhecem na narrativa homens destinados ao bem ou ao mal. Essa dupla divisão comprovaria a ausência de fronteiras entre o mundo humano e o dos deuses (entendido como o das forças naturais). Já o absolutismo do tempo primordial encontra-se na identificação entre o momento histórico, a despeito de suas peculiaridades, e a existência de um primitivismo essencial. Uma última totalidade estaria na identificação entre a palavra e o que ela nomeia, como se lhe fosse inerente:

[... ] esta unidade entre a fala e o referente não resulta da cosmovisão mítica, mas é de fato o seu princípio; é no momento em que a enunciação se confunde com o acontecimento enunciado que, de certo modo, o modifica e lhe dá o cunho de mito. Este, portanto, acaba denunciando seu caráter como produto da palavra e, concomitantemente, como produto de uma inversão: a do signo (convenção) em acontecimento (Zilberman, 1977, p.99)

No entanto, a autora lembra que a narrativa rosiana não pode ser confundida com o mito em si, uma vez que já se declara antes de tudo como uma narração, a de Riobaldo a seu ouvinte. Em vez disso, o universo mítico no romance é posto em xeque, pois convive com a ameaça de destruição pela cidade: o sertão, enquanto espaço, e sua primitividade, enquanto tempo, correm o risco de desaparecer sob o avanço da civilização urbana e sua nova era. Esse movimento que anuncia o desaparecimento do contexto mítico aparece no romance, 
segundo a autora, mais como uma transformação regular e espontânea do que como uma catástrofe.

$\mathrm{O}$ reconhecimento da presença do mito no romance $O$ coronel $e$ o lobisomem se dá de modo semelhante ao percurso trilhado tendo como objeto o romance rosiano. Para Zilberman (1977, p.99), o absolutismo da natureza no romance carvalhiano provém igualmente da caracterização do espaço em que se desenrolam os episódios: "o Sobradinho e seus arredores [...] agem como um microcosmo, porque sintetizam o mundo para o coronel, aparecendo concomitantemente como espaço mágico, distinto na sua constituição do espaço dessacralizado da cidade". Nessa conjuntura, verifica-se a inexistência de limites entre o mundo humano e não humano (pelos processos de antropomorfização e animalização dos seres), bem como entre o ordinário e o extraordinário (pela presença de fantasmas e seres lendários). No entanto, o mais importante rompimento dos limites naturais é, segundo a autora, a possibilidade de superação da morte experienciada por Ponciano. Desse modo, ocorre a anulação do conceito de morte enquanto fronteira, já que o protagonista por ela passa sem sequer dela tomar ciência. A continuidade do espaço, superando a vida e a morte, não impede, porém, a circunscrição de uma "região fixa" identificada com o campo, confirmando o vínculo entre concepção mítica e modelo de economia agrícola:

Assim, quando o coronel se fixa por um certo período na cidade, que como no texto de Guimarães Rosa é a ameaça mais concreta à dessacralização do mundo mítico, ele vem a participar de um mundo profano, onde desaparecem os seres mitológicos, erguem-se limites rígidos entre os reinos e à morte é atribuído o final da existência. (Zilberman, 1977, p.100)

Correlata à totalidade do espaço natural encontra-se a unidade do tempo primordial, também detectada pela eliminação da distância entre a vida e a morte, o que permite que o avô de Ponciano retorne depois de morto em forma de assombração. A autora observa ainda que a passagem do tempo na cidade é marcada por contagem 
cronológica, enquanto no campo se registra pela associação aos ciclos naturais.

A última unidade, entre o signo e o referente, também se estabelece nesse romance, de maneira que tudo o que a palavra denomina corresponde a um acontecimento. Isso se faz notar, aponta a autora, no episódio em que Ponciano, ao relatar um caso de assombração a Juquinha Quintanilha, com o intuito de assustá-lo, acaba por também amedrontar-se com a história contada. Além desse momento, há também aqueles em que o exagero das aventuras contadas acaba por se tornar expressão da verdade. No entanto, o protagonista não é o único responsável por esse que é um ato coletivo: “[...] não é só o coronel que inventa, criando fantasias que são encaradas como realidade, já que todas as pessoas que convivem neste meio ajudam a expandir a fama dos feitos de Ponciano" (Zilberman, 1977, p.101). Assim, as formas que buscam nomear o mundo são assumidas como verdadeiras, identificando-se aos seres e objetos a que dizem respeito. $\mathrm{O}$ alardeado sucesso de Ponciano com as mulheres ocorre apenas nesse plano. Nisto a autora identifica um "crescente afastamento da realidade nos modos de fazer referência a ela, desde a imaginação até o delírio” (Zilberman, 1977, p.101). Para o leitor, por outro lado, permaneceria a "distinção entre os dois reinos, o do real e o da fantasia, aparecendo-lhe o texto como produto de ficção, num posicionamento que difere de Ponciano”. Ou seja, para Zilberman, a palavra manifesta sua capacidade de tornar o contado como realidade apenas na perspectiva de Ponciano e de outras personagens, mas não na do leitor, que consegue manter distanciamento a esse artifício. O limite da palavra que constrói a unidade de um mundo mítico está na ameaça do pensamento de um mundo urbano dessacralizado, representado na narrativa.

Depois de indicar tais índices da presença do mito nos romances, Zilberman passa a analisá-los por suas estruturas. Em $O$ coronel e o lobisomem, a autora reconhece o modo de ser de um romance picaresco ou de uma série de contos, em que, portanto, a ação central não aparece necessariamente marcada em subsequências centrais, como é o caso do romance rosiano. Além disso, a narrativa estaria cindida em dois grandes momentos: os oito primeiros capítulos tratando das 
aventuras do coronel no campo, enquanto os demais, de sua vivência na cidade. Na primeira parte é que se notaria o caráter picaresco. A autora prossegue analisando os episódios de um ponto de vista da semiótica narrativa, a fim de determinar o sentido dos elementos míticos em seu interior.

Por essa análise, reconhece que nas aventuras do coronel há sempre uma tarefa a cumprir, com o intuito de reestabelecer uma ordem prévia e eliminar um determinado mal (brigar com o gigante, caçar uma onça ou lutar com o lobisomem). Ao processo de cumprimento dessas tarefas, no entanto, impõe-se sempre um impedimento por parte do coronel que, alegando não ter autorização superior ou afirmando ser ato desonroso à sua patente militar, delega então a missão a um outro agente, como o galo Vermelhinho que vence as rinhas ou o menino que mata a onça em seu lugar, ambos trazendo-lhe fama. Nesses casos, "a instância da palavra terá sempre um papel harmonizador, conciliando o coronel consigo mesmo e com o meio ambiente" (Zilberman, 1977, p.122). Embora o leitor perceba o espaço criado entre ação e denominação, a unidade de ordem mítica permanece intacta no mundo interior ao texto. Assim, fuga transforma-se em enfrentamento e se anulam os polos contraditórios. Segundo Zilberman (1977, p.122-3),

[...] os elementos míticos que assinalam o texto [...] têm um papel marcante no interior da narrativa, já que anulam os seus conflitos internos. Isto é, para que a aventura não se descaracterize, é preciso a invocação de um universo mítico que assegure uma unidade tal que evite a revelação da falsidade no interior da mesma. Neste sentido, guardando-se as proporções entre o estilo cômico de J. Cândido de Carvalho e o épico de J. Guimarães Rosa, estabelece-se um ponto em comum entre o cumprimento da tarefa por Ponciano e Joca Ramiro: em ambos, ele apresenta uma falha que denuncia ao leitor a sua transitoriedade, mas que encontra uma harmonização através da presença do mito. Mais uma vez, o mito aparece como um fator de equilíbrio dentro da sociedade representada assegurando a inexistência de contradições, pelo menos ao nível aparente. 
As tarefas cumpridas realmente por Ponciano, no entanto, só dizem respeito aos seres extraordinários, de modo que "são estes que asseguram a fama real do coronel, sobretudo diante do incrédulo leitor, porque, mesmo após uma fuga, ele os enfrenta e derrota-os" (Zilberman, 1977, p.123). A autora reconhece, portanto, que os episódios sobrenaturais impõem-se como realidades no interior da narrativa mesmo ao leitor incrédulo que reconhece o engodo do restante do relato. Assim, o mundo mítico, alicerçado por uma visão mágica do real, apresenta-se como algo imprescindível para legitimar a fama e a superioridade do herói sobre o meio em que vive. Essa saída, porém, não é possível para a missão de conquistar uma mulher com quem possa se unir e ter filhos, e nisso surge um segundo padrão estrutural que a autora reconhece na narrativa. $\mathrm{O}$ universo citadino em que Ponciano busca suas pretendentes com a finalidade de se casar surge como o empecilho a seu êxito, pois se opõe ao universo mítico do campo, inviabilizando o estabelecimento de qualquer união e levando o herói ao fracasso, além de não permitir o êxito com as mulheres pelo plano mítico. Por essa razão, a autora visualiza uma associação consonante a tal oposição espacial: enquanto o elemento feminino estaria circunscrito ao ambiente urbano (cultura), que lhe estaria vedado, o masculino estaria representado pelo campo (natureza), único espaço em que Ponciano alcançaria sucesso. Esse impedimento relacionado ao gênero se daria também em Grande sertão: veredas, com a impossibilidade da união de Riobaldo e Diadorim.

Por reconhecer que o espaço rural marca o distanciamento entre ele e seu objeto de desejo (o elemento feminino), Ponciano muda-se para a cidade, fase que corresponde à segunda metade do romance e a um terceiro padrão reconhecido pela autora. Esse é o momento em que se inicia a trajetória de queda de Ponciano: apaixonado por Esmeraldina, crendo-se correspondido, mas sendo enganado, ele é levado à falência. Em sua tentativa de adaptação, Ponciano carrega para a cidade os valores e o comportamento do meio rural, e por isso fracassa. Assim, amplia-se a esfera do vedado: "Não somente é a mulher, mas o ambiente em que ele circula, a cidade. $\mathrm{O}$ acesso à cultura torna-se impossibilidade para Ponciano, e ele volta ao campo". 
(Zilberman, 1977, p.126). Esse terceiro padrão estrutural detectado pela autora é assinalado por elementos da narrativa burguesa: ascensão e queda de um homem de negócios; fracasso sentimental associado à derrocada financeira; relações pessoais reificadas e interesseiras. Além desses pontos, se oporiam aos outros dois padrões: a presença do realismo em oposição à presença dos elementos mágicos da primeira parte; mudança de cenário, do rural ao urbano; mudança nas relações pessoais, antes alicerçadas no favor e depois nas relações de compra e venda; e o abandono da estrutura picaresca, constituída por episódios de estrutura idêntica, por uma narrativa de desenvolvimento linear. Esse novo modelo narrativo no interior do romance corresponderia a um novo mundo que não pode ser abordado pelas regras do primeiro, o que criaria a seguinte correspondência: o mundo rural estaria para a narrativa fechada e a presença do mito na mesma proporção em que o mundo urbano estaria para a narrativa linear e o mundo dessacralizado.

O último movimento, a volta de Ponciano empobrecido e decadente para o campo, marcaria um retorno ao primeiro padrão narrativo, pois é o momento em que o herói, depois da morte, irá travar uma luta com o Diabo, em um retorno claro às aventuras extraordinárias: "Para Ponciano, a morte aparece como um sonho, do qual acorda percebendo-se com capacidades extraordinárias" (Zilberman, 1977, p.127). Desse modo, a narrativa deixa de ser linear para adquirir novamente uma estrutura mítica, fechada e repetitiva. O mito, no entanto, caminha para seu desaparecimento e superação, como também ocorre no romance rosiano:

Enquanto presença, ele [o mito] se constitui, como já dava conta Grande sertão: veredas, pela emergência de um mundo masculino, a meio passo da natureza e da cultura, polos opostos que exigem uma opção. Riobaldo opta pela segunda [cultura] e pela palavra consciente, que é a narração e não mais o relato mítico; Ponciano decide-se pela primeira [natureza] quando percebe que a História, mesmo no universo preferentemente mítico, orienta-se para o outro lado, e pelo silêncio. No primeiro caso, o mito, anulando-se, acaba por dar 
conta do seu contrário: a narrativa dessacralizada, onde existe homem humano, e executa a última fundação: a da civilização. No outro caso, o mito permanece, mas acaba superado pelas contradições estabelecidas por ele mesmo (palavra X ação), emergindo daí também um mundo não mítico porque anterior a este, mas não uma fundação.

Assim, em ambos os casos permanece o contexto da destruição do universo mágico, sendo que a transição do mundo do mito ao da realidade dessacralizada aparece como resultado do progresso histórico. Essa transição equivale ainda a uma passagem "do mito à literatura" - e nesse ponto esclarece-se o título do livro de Zilberman -, pois ambos são livros de memórias, problematizando o ato de narrar. O reviver do mito pela palavra provocará a oposição entre relato mítico e narração enquanto fator da existência, de modo que no conflito entre mito e literatura, a última se impõe: "O contador passa então do universo do mito ao da palavra dessacralizada, do mundo do imanente ao do conceito [...]" (1977, p.130). Para sintetizar, os romances teriam em comum: uma cosmovisão mítica; um antagonismo entre mundo mítico e profano em que este se sobrepõe pela presença das contradições internas do mito; e a existência de um conflito entre mito e literatura, do qual esta se sobressai. Disso, a autora extrai que a presença do mito no interior de um texto literário pode determinar uma tipologia, sendo o suficiente para delimitar uma série de narrativas. Nelas se verificaria que "o mito é sempre suprimido no final, o que só faz intensificar a noção de começo, pois trata-se do princípio de um contexto não mítico, onde a palavra é invocada para traduzi-lo, uma palavra nova e primeira" (Zilberman, 1977, p.131).

Pela análise da estruturação mítica nas narrativas, Zilberman (1977, p.137) conclui que o mito "conta o início de uma organização social”, depois de expor uma época original em que o homem estava atado à natureza e era dela dependente. Essa submissão do homem à natureza é o que permitiria a "eclosão do sobrenaturalismo do real, admitindo a presença de seres extraordinários mesclados ao cotidiano". Porém, a autora lembra que o pensamento mítico ligado à natureza pode não desaparecer totalmente mesmo depois 
dessa transformação fundamental (da natureza à cultura). Riobaldo enfrenta a transformação deixando de ser jagunço e casando-se, enquanto que Ponciano é incapaz de empreendê-la, e retorna a um estágio anterior. Em todo caso, ainda que o mito se integre à narrativa, ele não a abrange na sua totalidade, pois todos os textos ao final dão conta de sua superação: "eles são vistos como passagem histórica, fruto da evolução que o próprio mito quer esconder, mas que acaba impondo-se" (Zilberman, 1977, p.138).

Depois de verificar a estrutura do mito nos romances de José Cândido e Guimarães Rosa, Regina Zilberman procura as raízes desse fenômeno no interior da literatura brasileira a fim de compreender como sua incorporação se processa, especificamente na ficção nacional. Para tanto, a autora elege as narrativas Iracema, de José de Alencar, e "A Salamanca do Jarau", do livro Contos gauchescos e lendas do Sul, de João Simões Lopes Neto, como textos precursores dessa linhagem que busca a construção de um mito para o Brasil. Após passar por esses textos do Romantismo e do Pré-Modernismo, Zilberman inclui também em seu percurso investigativo produções, inclusive em verso, do Modernismo: Martim Cererê, de Cassiano Ricardo, Macunaima, de Mário de Andrade, e Cobra Norato, de Raul Bopp. Por esse esforço de encontrar, desde Iracema, o princípio de uma tradição no interior da literatura brasileira, Zilberman garante um avanço notável em relação à análise de Dacanal que, ignorando as raízes do fenômeno mítico na literatura nacional, partia diretamente da oposição entre os romances brasileiros e o romance burguês europeu.

A trajetória de formação dessa linhagem estabelecida por Regina Zilberman é em parte legitimada pelo próprio José Cândido de Carvalho que, em entrevista concedida quando da publicação de $O$ coronel e o lobisomem, revela: "Para escrever esse romance tive muito cuidado e reli muita gente: Guimarães Rosa, Mário de Andrade, Cavalcanti Proença e, ainda que pareça estranho, Eça de Queiroz" (Carvalho, 1964, p.2). Diante da pertinência da associação, convém registrar algumas das considerações da autora sobre o romance de Mário de Andrade, pautadas nos estudos referenciais Roteiro de 
Macunaíma, de Cavalcanti Proença, e Morfologia de Macunaíma, de Haroldo de Campos.

Com base no primeiro, a autora recupera a ideia de que Macunaíma se aproxima da epopeia medieval, já que guarda em comum com essa tradição a sobre-humanidade do herói e a presença do maravilhoso. Assim, o protagonista, que reúne traços considerados essenciais à composição do indivíduo nacional, encontra-se fora do tempo e do espaço, numa gama de variedades regionais que lhe proporciona uma identidade móvel. Na mesma direção, da reflexão do segundo a autora resgata a aproximação de Macunaíma aos contos maravilhosos da literatura russa, cuja morfologia é estudada por W. Propp. Essa associação seria possível em função da utilização, pela rapsódia de Mário, de fontes populares de caráter mágico, como as lendas que remetem a um pensamento primitivo, original. Alinhavando as obras, a autora demonstra que Macunaíma corresponderia a um momento de contestação do mito:

[...] percebe-se a unidade que existe entre este texto [Macunaíma] e os de Simões Lopes, onde predominam as categorias do maravilhoso e sobrenatural, presentes numa criação que se apoia na tradição folclórica. E o Macunaíma mantém ainda um vínculo com Iracema, cujo início imita de modo paródico. (Zilberman, 1977, p.175)

[...] a rapsódia de Mário circula no meio mítico estabelecido por Alencar e Simões Lopes Neto, mas de modo anárquico, parodiando suas realizações e tomando diante delas uma posição crítica. A obra configura-se então como um espelhamento que, refletindo uma imagem deformada do objeto a que se refere, põe à luz o seu caráter de consagração dos valores aceitos na sociedade. Nestes termos, o autor transita por esse ambiente, afastando-se dele e indicando que, se se coloca a possibilidade da crítica, esta somente se torna possível quando de fora, através do riso. (Zilberman, 1977, p.177)

O riso, uma conquista e atitude típica do Modernismo, implica um distanciamento que a narrativa mítica não comporta. Assim, 
Macunaíma anula a índole mítica, investindo-se de uma perspectiva de demolição. Também em decorrência desse distanciamento, segundo a autora (1977, p.181), as obras modernistas, apesar de situarem seus heróis no sertão ou na floresta, eliminam essa espacialidade, "transformando o ambiente em cenário, papel pintado, através de conceitos vagos que os designam: no fundo do mato virgem, Terras do Sem-Fim". Esse "sequestro do contexto", que acentua a personalidade exótica dos elementos, se desfaz, no caso de Macunaíma, apenas quando o herói está em São Paulo. E, por essa razão, Zilberman (1977, p.181) lembra: "Mário de Andrade é o homem da cidade [...] e são os problemas do Brasil urbano que realmente afluem na rapsódia”. Desse modo, o americanismo do programa modernista é relativizado, já que o mundo rural é abolido e a sua ideologia de fundo localista é identificada às populações regionais. Daí a autora (Zilberman, 1977, p.181) concluir que "o Modernismo, tendo a intenção de levar às últimas consequências a questão [do americanismo], acaba por suprimi-la sem resolvê-la, adiando o problema para a geração seguinte".

A última parte do estudo de Regina Zilberman apresenta um panorama das modificações do romance brasileiro posterior a 1928. Retomando uma proposta de sistematização de Antonio Candido, segundo a qual a literatura brasileira dos anos 1930 coincidiria com um momento em que se aflora a consciência do subdesenvolvimento do país, Zilberman afirma que a ficção desse período é marcada pela denúncia social, em uma linha combativa, engajada e de feição neorrealista. Embora saliente que o espaço ficcionalizado nos romances é tanto o urbano quanto o rural, a autora reconhece a predominância do último, por permitir que se revelem as condições de miséria e sub-humanidade de regiões interioranas. No plano histórico, a crise de 1929, ao reduzir a capacidade nacional de importação de produtos, teria impulsionado um novo esforço de industrialização do país. Assim, o romance dos anos 1930 incorpora os efeitos dessas modificações econômicas e sociais, sinalizando a necessidade de reformas no campo.

A autora nota que mesmo narrativas que tomam a cidade como cenário revelam, muitas vezes, a dependência econômica do meio 
urbano em relação à produção agrícola rural, condição natural, uma vez que se trata de uma modernização ainda incipiente. Assim, Zilberman (1977, p.184) conclui que das obras analisadas, tanto anteriores quanto posteriores ao Modernismo, o espaço em que a mentalidade mítica se desenvolve é o campo: "Neste sentido, o corpus pensado sincrônica e agora diacronicamente possui este importante ponto em comum com o desenvolvimento da literatura brasileira: ele é regionalista [...]". As obras que analisa coincidiriam, portanto, com o regionalismo enquanto uma tradição literária nacional, mas dentro dessa tendência maior se individualizariam pela presença do mito. Diante dessa constatação, a autora busca compreender o fenômeno de assimilação do mito pela literatura regionalista, mas para tanto utiliza-se de um instrumental semiótico:

O mito é, antes de tudo, a antítese do regionalismo; este é a condição histórica de uma nação, o mito é a sua transfiguração em a-historicidade, inscrevendo as narrativas numa tradição imemorial, dada pelas narrações bíblicas ou da fundação da cidade eterna, Roma. O regionalismo é a espacialização da literatura, o mito é a sublimação do específico em genérico. Em outras palavras, o mito incrustado na literatura regional é a sua modificação em fatalidade, tornando-se a afirmação positiva (logo, mandamento) dos valores que são justamente aqueles que devem ser vencidos para que haja justiça social; por isso, constrói-se sobre o dever-ser (mandamento) e o seu contrário (proibição), exercendo um papel de controle sobre as contradições sociais e mascaramento do equilíbrio. (Zilberman, 1977, p.185, grifos da autora)

Em Alencar e João Simões, seria pelo mito que os valores regionais $-e$, portanto, subdesenvolvidos - se tornariam universalmente válidos, narrando suas origens e a engrenagem de sua repetição, no sentido de afirmar, pelo elemento mitológico, a ideologia da classe social dos latifundiários que dominavam a política da época. No entanto, o desenvolvimento industrial iniciado nos anos $1930 \mathrm{e}$ intensificado nos anos 1950 levou a um gradativo esvaziamento do 
poder do grande latifúndio. Diante disso, a autora (Zilberman, 1977, p.185) questiona: "Se é assim, por que ocorrem agora [anos 1970] tais narrativas fundamentadas no mito e numa ideologia que é a da preservação da propriedade agrária e confirmação a nível mágico de sua vigência?". E a explicação aparece na sequência: "Acontece que, se os textos lidam com personagens ligadas à produção agrícola, buscarão eles uma forma que seja o verdadeiro modo de expressão da classe dona de terras" (Zilberman, 1977, p.185). Desse modo,

[... ] a causa do emprego do mito como elemento unificador da narrativa deveu-se à sua identificação com a classe social a que se referia; porém, ele ainda se vale desse modo expressivo por uma última razão: é ele que decreta o inalterável e consagra o status quo porque permanente retorno à origem; e é esta que convém aos proprietários, quando percebem, como Ponciano, que o seu tempo de predomínio passou. E, se isto de fato se deu, a alternativa é anular o tempo, atividade para a qual concorre o mito. Com efeito, [...] os textos onde ele aparece surgem num momento historicamente determinado, aquele em que os privilégios desta mesma classe estavam ameaçados pela introdução ou fortalecimento de uma burguesia oriunda da ascensão industrial. (Zilberman, 1977, p.186)

A diferença entre as primeiras narrativas que plasmam o mito (como Iracema) e o estágio em que o fenômeno se encontra na prosa posterior a 1950 (como Guimarães Rosa e José Cândido) estaria em uma questão de - salvo engano, pode-se dizer - perspectiva, pois os últimos: "veem o processo de dentro, como um desenvolvimento de uma origem [...] e um fim que [...] é a derrocada de uma classe específica, imposta pela evolução por que passou o país desde os tempos coloniais até o presente" (Zilberman, 1977, p.187, grifos nossos). O mito em Alencar e Simões Lopes Neto, embora procure manter seus vínculos com o folclore ou com a tradição aborígene, se estabelece como "uma última máscara que a intenção imperialista - associada com a classe proprietária rural, que sempre tira partido dessas narrativas - assume" (Zilberman, 1977, p.167), ou seja, é o imperialismo 
europeu que triunfa, de uma perspectiva externa. Para melhor esclarecer esse ponto, convém lembrar que a autora (Zilberman, 1977, p.144) demonstra, na análise de Iracema, como José de Alencar destrói os efeitos mágicos do texto ao fazer coincidir a voz do narrador à perspectiva racional do homem branco e civilizado, representado na figura do protagonista Martim. ${ }^{12}$

No entanto - e este parece ser um dos pontos mais profícuos e intrigantes da reflexão de Zilberman - essa perspectiva interna, o olhar "de dentro" do processo, contida nos romances de José Cândido e Guimarães Rosa, não significaria necessariamente, segundo ela, a conquista de autonomia em relação aos valores europeus ou ainda a libertação de uma tradição literária de jugo estrangeiro.

A autora chega a essa conclusão a partir da discussão da ideia, de Mario Vargas Llosa, de que os grandes romances refletem sociedades que estão por perecer: para a autora, a derrocada de uma sociedade aparece, como se viu, representada nos romances em questão pelo processo mítico. Esse fenômeno se ligaria aparentemente ao programa do Real Maravilhoso, proposto por Alejo Carpentier, momento em que a ficção latino-americana se ocuparia da cosmovisão selvagem e do pensamento mágico inerente à formação do continente, opondo-se à tradição da narrativa ficcional europeia. Com efeito, retomando Antonio Candido, Zilberman sustenta que todo o esforço da literatura brasileira, desde o Romantismo, foi o de afirmar sua autonomia por meio de uma série de correntes que quiseram criar padrões e arquétipos nacionais (indianismo, regionalismo, nativismo modernista etc.). As principais respostas a essa necessidade se deram pela escolha de "temas novos", peculiares à

12 Regina Zilberman exemplifica o esforço de José de Alencar em conferir verossimilhança à narrativa de Iracema quando, pelo narrador, busca explicar de uma perspectiva objetiva e racional os ritos aborígenes, impedindo, com isso, a aceitação de qualquer realidade mágica que esses rituais pudessem conter: assim, os efeitos de um determinado licor não corresponderiam a uma imersão "real” numa realidade "mágica", mas sim a um "sonho" mágico, o que equivale a uma explicação racional para o fenômeno. 
realidade nacional, e isso culminaria com a recusa inclusive das formas literárias importadas.

Nesse sentido, romances como os de Rosa e José Cândido não apresentariam uma forma nova de representar, ao afastarem-se da mimese como princípio da arte ocidental e se aproximarem do mito? E não seria essa, como queria Carpentier, a possibilidade de descolonização no plano artístico? A resposta de Zilberman, contrariando aparências, é não - pelo menos num plano ideológico. Para a autora (Zilberman, 1977, p.188-9), essa literatura, embora expressando uma visão interna do processo e assumindo um novo modo de representação, continua a afirmar, na verdade, valores europeus:

[...] levando-se em conta os casos aqui analisados, os resultados contradizem a hipótese, já que sempre culminam com a afirmação dos valores europeus. Aliás, a conclusão não poderia causar estranheza. Com efeito, se eles traduzem uma passagem e uma derrocada como resultado das transformações promovidas pela industrialização, a ascensão, entrevista nas sagas individuais [Grande sertão: veredas e O coronel e o lobisomem], é a da civilização burguesa, que, no Brasil, caracteriza-se pela inautenticidade de sua autonomia, pois depende da inversão de capitais estrangeiros. [...] Devido a isto e aos fatos antes mencionados, ainda não é aquela forma que libertará a nossa literatura, mesmo porque não resiste até o final dos textos; na verdade, ela é sobretudo o que se afirmou acima: aquela expressão vinculada às personagens do texto, ligadas a uma economia agrícola. Mas não libera uma tradição literária de um jugo estrangeiro, assim como o passo histórico seguinte, que nestas obras às vezes é assinalado, não produziu a independência econômica.

Zilberman (1977, p.189) defende que não se pode considerar realizada a perseguida descolonização de que trataria o romance latino-americano ao narrar o estado de crise e decomposição de uma sociedade, o que viabilizaria uma arte "realmente autóctone". A argúcia crítica da autora a leva ainda a questionar - mesmo na década de 1970, ou seja, estando muito próxima temporalmente ao 
fenômeno - qual seria a validade de um programa que defende o "específico americano", uma vez que isso poderia revelar, por seu revés, uma intenção exotista, como a dos europeus no século XVI em relação ao novo continente. Assim, sustentando uma perspectiva que contempla a relação dialética entre o dado local e o estrangeiro na literatura nacional, a autora (1977, p.189) estabelece o fulcro de seu raciocínio:

$[\ldots]$ o verdadeiro americano $[\ldots]$ radica na humanidade do indivíduo deste continente e, se o poeta traduz dramas locais, estes só terão significado se se integrarem num projeto de liberação do homem, seja do Terceiro Mundo ou das potências imperialistas. Devido a isto, a não identidade destes textos com esta ideologia americanista pode tornar-se uma virtude; em contrapartida, eles podem chegar ao extremo oposto, crendo inelutável (em alguns casos, com júbilo, como Alencar) a ocidentalização. Há, pois, uma dualidade neste processo, estando cada narrativa atada de um lado a um patrimônio cultural e ideológico do qual até agora toda a América não pôde escapar e de outro, a este esforço liberador que a faz aderir à transformação histórica e à revelação de suas condições. E sem se levar em conta tal ambiguidade, que é o pathos do Terceiro Mundo, jamais se compreenderá esta mesma realidade, o seu meio caminho entre a opção por si mesmo e a sedução de uma direção tida como inevitável.

Aos que pudessem indagar pela falta de atrelamento da discussão à questão do gênero romance, Zilberman responde buscando em Bakhtin (1998) o sustentáculo e a legitimação de sua abordagem pelo viés do mito: conforme afirma, pela presença do componente mítico em sua aliança com a classe latifundiária, os textos estudados poderiam, caso ao final não revelassem uma derrocada, ser epopeias. Mas, como o fazem, configuram-se, na verdade, como romances, gênero que surge entre outras criações populares justamente parodiando as formas literárias derivadas do mito e utilizadas pela classe aristocrática. Gênero sempre móvel, proteico, afinado à evolução de uma realidade, associado ao progresso, o 
romance seria, portanto, a forma de expressão mais adequada para representar as tendências de edificação de um mundo novo, de uma nova configuração social.

Diante disso, é possível perceber o quanto a reflexão de Zilberman avança em profundidade ao se utilizar, com propriedade, de conceitos antes mobilizados sem rigor e precisão por Dacanal. A autora compreende, portanto, o fenômeno de incorporação do insólito no romance $O$ coronel e o lobisomem como a integração do mito à narrativa romanesca. No entanto, o componente mítico, utilizado como instrumento de afirmação de uma sociedade latifundiária em vias de desaparecimento, não resistiria enquanto "mito" no texto. Permaneceria, assim, apenas o contexto da destruição do universo mágico. Isso porque, segundo a autora, problematiza-se, nesse romance e também em Grande sertão: veredas, ambos livros de memórias, o ato de narrar. Desse modo, Do mito ao romance explora a possibilidade de existência de uma relação de oposição entre o relato mítico (o mito) e a narração (o romance) nessas obras.

Mas a autora reconhece uma diferença entre as obras na configuração desse processo, guardada aqui para o final para melhor discuti-la: segundo ela, se desse embate sobreviveria, no romance de Guimarães Rosa, a palavra dessacralizada (o romance, a narração, a literatura) acima do mito, no de José Cândido, por outro lado, o rompimento com o mundo mítico se daria pelo silêncio final, pela anulação da palavra (aliada ao mito), dada a total inserção de seu agente, Ponciano, no universo natural. Isso porque a palavra para Ponciano seria um modo de solucionar conflitos. Nisso residiria a diferença do tipo de aproveitamento do mito entre as obras. Em suas palavras: "Esta é a contrapartida da questão discutida, pois, se no texto anterior [Grande sertão: veredas] a literatura aparece como possibilidade num mundo profano, aqui [O coronel e o lobisomem] ela some, junto com o mergulhar de Ponciano no universo natural" (Zilberman, 1977, p.130). Tal mergulho o levaria ao silêncio, à destruição do mito: "Para Ponciano, a palavra desempenha também um papel fundamental, o de harmonizar os conflitos e confirmar a veracidade das aventuras do coronel; em vista disso, ela é uma aliada do 
mundo mítico, aliança que se rompe somente quando o agente opta pelo silêncio, isto é, pela sua anulação".

Se é dada a possibilidade de divergir de algo em seu raciocínio, o ponto parece ser este: embora não comprometa o restante de sua direção argumentativa, parece contestável a afirmação de ser o silêncio de Ponciano, ao final, a razão do rompimento com o mundo mítico. Zilberman (1977, p.130) entende que a palavra é "aliada do mundo mítico", por "harmonizar os conflitos e confirmar a veracidade das aventuras do coronel”. No entanto, não seria exatamente o contrário? A palavra, na realidade, trai Ponciano e, ao invés da harmonia, instaura um conflito entre ele e o mundo: é seu discurso que o denuncia. E mais, a palavra de Ponciano não o trai apenas ao expor as fraquezas dele ao outro - como personagens e leitor que o percebem ingênuo -, sua palavra o trai também ao fazê-lo nela acreditar, ou seja, só a ele ela confirma a veracidade de suas aventuras, na medida em que acaba aceitando-a e dela se convencendo.

Nesse sentido, são esclarecedoras algumas considerações feitas por Nelly Novaes Coelho em 1966 - ainda que a autora não mencione o papel da palavra como agente do engodo armado por Ponciano a si próprio: segundo ela, as ocasiões em que o coronel se aproveita de situações ou se vangloria por sua coragem, mas que acabam revelando seu medo, não fazem dele necessariamente um farsante, antes denunciam sua ingenuidade:

Aí estão os contrastes do nosso quixotesco herói, com seus rompantes e suas bazófias; indiscutivelmente homem conhecedor dos homens e sagaz explorador das circunstâncias favoráveis. Porém o curioso é que apesar de essas fragilidades estarem registradas abertamente [acrescente-se: pela palavra]; em momento nenhum, o Coronel nos dá a impressão de ser covarde... A sensação final que nos fica (mesclada a uma certa malícia e bonomia) é a de uma tocante coragem: a coragem dos fracos, que não têm consciência de sua fraqueza e muito simplesmente acreditam na própria fortaleza e confundem valentia com os astutos recursos usados, a fim de se porem a salvo; e salvaguardarem as aparências. 
Coronel Ponciano não é, pois, um farsante; é um homem cheio das muito naturais fragilidades humanas, mas que acima de tudo acredita em si mesmo; em sua força; em seu poder, tal como D. Quixote acreditava na alta estirpe de seu Rocinante; e em sua missão cavalheiresca de defender os fracos e espalhar a justiça na terra. E é devido à crença ingênua que Ponciano revela ter em sua própria grandeza, e em seu papel dentro daquele pequeno mundo, que o vemos como o D. Quixote de nossa ficção. Um coração generoso e manso que se queria ver como um "coração de leão". (Coelho, 1966, p.348-9)

Ao ser traído pelo próprio discurso, ao acreditar nas histórias fantasiosas que inventa, ao crer-se portador de poderes sobre-humanos, Ponciano parece assumir, em sua figura, uma representação do Brasil, em sua euforia desenvolvimentista, no contexto mundial da época de publicação do romance. No entanto, como o desdobramento dessa hipótese conduz a uma nova possibilidade de leitura da obra - leitura que aqui se quer propor como modo de atualizar sua fortuna crítica -, convém guardá-la para o terceiro capítulo deste livro, de modo que, por ora, apenas assinalando-a e mantendo-a em perspectiva, se prossiga com a visada crítica de Zilá Bernd.

No artigo "O maravilhoso como ponto de convergência entre a literatura brasileira e as literaturas do Caribe”, Zilá Bernd (1998) propõe uma leitura do romance $O$ coronel e o lobisomem pelo aporte teórico do realismo maravilhoso. Na primeira parte do artigo, "Literatura brasileira (e latino-americana): entre racionalidade e magia”, a autora retoma a questão já apontada por Zilberman (1977), de que a literatura brasileira se afirmaria, desde seu princípio, pela busca de uma identidade nacional. Para tanto, a fonte de sua diferenciação estaria no "maravilhoso americano", oriundo do aproveitamento das culturas autóctone e africana. Segundo a autora, a escrita praticada pelas elites buscou sempre privilegiar formas eruditas herdadas de uma tradição greco-latina, de modo a ignorar o imaginário maravilhoso presente nas culturas de povos subalternos: "[...] até o Modernismo, o imaginário mágico-sacral ou é excluído das diversas 
formas de representação literária ou é captado a partir de uma visão exógena, mais no sentido de obter o que se costuma chamar de cor local" (Bernd, 1998, p.1). Assim, os modernistas seriam os primeiros a tentar incorporar a visão mítica das cosmogonias americanas ao patrimônio letrado, como ocorre com a obra de Mário de Andrade, ao buscar abolir a distância e a hierarquização entre cultura de extração popular e cultura erudita.

Esse projeto de aproximação, no entanto, seria abandonado pelo romance de 1930, que tomou os rumos do engajamento e da denúncia da situação de opressão em que vivia principalmente a população nordestina. No romance de 1930, essa denúncia se fazia pela neutralização do misticismo popular:

[...] por estar inteiramente comprometido com a melhoria da situação dos oprimidos, [o discurso do romance de 1930] procurará neutralizar todo o misticismo presente na cultura popular por considerar que é precisamente este misticismo que conforma a postura submissa dos desfavorecidos face a seus opressores. (Bernd, 1998, p.2)

Com essa ideia, a autora reitera a formulação de Alfredo Bosi (1988), no ensaio "Céu, inferno". Nesse texto, o autor compara a ficção de Graciliano Ramos à de Guimarães Rosa para concluir que, embora ambos fossem observadores de tipos, ambientes e situações arcaico-populares, haveria uma importante diferença entre eles: enquanto o primeiro, mediado pelo determinismo, teria dificuldades para aderir ao mundo mágico dos sertanejos, o segundo se aproximaria desse mesmo universo, mediado pela religiosidade popular. Nessa linha de raciocínio, conforme Bernd (1998, p.2), Rosa manifestaria sua adesão à cultura popular pelo modo de ver os homens e o destino, entrando, assim, em sintonia com "as versões simbólicas e maravilhosas da realidade que tecem os sertanejos para superar a extrema carência em que vivem". Na linha de García Márquez e Alejo Carpentier, Rosa assimilaria os relatos mágicos e insólitos dos iletrados, interpretando-os como formas alternativas de narrar os acontecimentos históricos e de aceitar o destino. José Cândido de 
Carvalho, nesse cenário, é um dos autores que teria superado essa dicotomia:

Assim, com Ramos, de modo ainda incipiente, e com Rosa, explicitamente, começam a ser desbravados os caminhos que levam à construção de um primeiro nível de hibridação onde se associam tradição oral e visão maravilhosa da realidade a elementos da cultura letrada. Será com José Cândido de Carvalho na década de 60 e com João Ubaldo Ribeiro, na década de 80, que estes antagonismos serão verdadeiramente ultrapassados, havendo uma real apropriação por parte do escritor dos aportes da cultura popular que são crioulizados com os da cultura erudita, tendendo-se a uma dissolução gradativa das fronteiras que separam as duas vertentes. (Bernd, 1998, p.2)

Assim, apenas a partir da década de 1960 se daria a plena adesão ao imaginário mágico, por um trabalho de apropriação, reutilização e reciclagem de formas oriundas da cultura popular, que permaneceram em situação de isolamento, na periferia do sistema. O romance O coronel e o lobisomem romperia com essa situação pela diluição das fronteiras entre logos e mitos, entre a racionalidade da literatura erudita e a "visão mágico-maravilhosa" dos contos e lendas da tradição popular (Bernd, 1998, p.3). A poiando-se no estudo de Irlemar Chiampi (1980), Zilá Bernd compreende esse fenômeno como um nível de hibridação praticado pela literatura do chamado boom dos anos 1950 e 1960. No entanto, Bernd discorda de Chiampi quando esta afirma que haveria nessa literatura resquícios de um princípio de hierarquização no qual a cultura popular ficaria num plano inferior ao da cultura erudita. Em todo caso, a presença dessas mesclas e reciclagens favoreceria a diversidade do mundo, afastando-se da ânsia do absoluto e produzindo uma escrita capaz de conferir identidade às literaturas das Américas.

Apesar de, em 1998, afirmar conhecer apenas os estudos de Dacanal (1973) e Miyazaki (1988), Zilá Bernd compartilha, de certo modo, novamente da opinião de Zilberman, pois na segunda parte do artigo, "O universo maravilhoso do coronel", defende que 
José Cândido se inscreva na mesma vertente de Mário de Andrade e Guimarães Rosa. Para Bernd, essa linhagem se caracteriza pelo cruzamento de elementos das culturas oral e popular e da cultura erudita, compondo "escrituras híbridas". Além disso, o romance $O$ coronel e o lobisomem se vincularia ainda à vertente latino-americana do maravilhoso, fato que, lembra a autora, Érico Veríssimo já teria reconhecido ao afirmar, quando da publicação da obra, que se estava diante de uma "espécie de realismo mágico".

Questionável no raciocínio da autora é a convicção de que o romance, por ser publicado no ano de 1964, seria uma crítica irreverente aos militares que praticaram o golpe militar. Como visto no primeiro capítulo deste livro, o romance já estava pronto há dois anos e desde 1963 encontrava-se com o editor à espera da publicação. Além disso, o eixo da trama, a história de um militar decadente, contador de histórias inverossímeis, já aparecia nas crônicas "A Guerra do Paraguai em pessoa”, de 1951, e "O Major”, de 1958. Logo, a autora se equivoca quando propõe:

[... ] não seria temerário afirmar que não foi mera coincidência o fato de JCC escolher este momento para falar de um coronel - figura símbolo de autoridade e arbítrio tanto na realidade como na ficção brasileiras - e de sua decadência e passeísmo (sic). O tom irônico e carnavalizado do romance diluiu o impacto da crítica irreverente e seu caráter subversivo. (Bernd, 1998, p.4)

Por outro lado, a leitura de Bernd se aprofunda quando resgata o trabalho de Tieko Miyazaki (1988) para discutir uma questão que perpassaria os romances Grande sertão: veredas, O coronel e o lobisomem e Sargento Getúlio. Segundo Miyazaki, essas obras, ao focalizarem distintos momentos e regiões brasileiras em vista de uma problemática geral do confronto de culturas, tratariam do desaparecimento da função histórica de algumas figuras: o jagunço, o coronel e o sargento, respectivamente. Desse modo, o desaparecimento da importância de tais funções seria sucedida por uma tentativa de reconquistar ou de reconstruir uma identidade perdida. O coronel 
Ponciano, diante de uma encruzilhada entre dois tipos de cultura, vê-se na tentativa desesperada de recompor sua própria identidade, daí a razão para o uso da primeira pessoa no romance: a narração em primeira pessoa, lembra a autora, é característica do discurso de afirmação identitária.

Nesse trabalho de rememoração do narrador, unem-se memória individual e coletiva, de modo que as recordações do coronel são entremeadas por mitos do folclore brasileiro e universal. Endossando a opinião de Irlemar Chiampi (1980), Zilá Bernd (1998) afirma que "poderíamos dizer que o narrador introduz o maravilhoso através do suporte da narração tética (representação do real), colocando real e maravilhoso em relação não contraditória, como ocorre nas narrativas do Realismo Maravilhoso" (Bernd, 1998, p.5). ${ }^{13}$ Em sua perspectiva, portanto, real e maravilhoso convivem na obra, fundamento que justificaria sua associação às narrativas do chamado realismo maravilhoso. A partir disso, a autora explica que em cenas como a do ururau e a da sereia, ocorre um processo de "naturalização do sobrenatural”, garantido, no caso do primeiro, pela descrição do animal em um jantar (uma situação real), e, no do segundo, pela pergunta da sereia sobre a possibilidade de se casar com o coronel. Desse modo, o insólito deixa de ser o "outro lado", ou o desconhecido, para incorporar-se ao real, como se o maravilhoso estivesse na realidade, conforme perspectiva de Carpentier. Explica, então, Bernd (1998, p.7): "Por isso, o narrador não se desconcerta diante do sobrenatural, dizendo apenas ter fingido espanto e que não se deixaria levar pela sereia para as 'profundezas das águas verdes'”.

Essa interpretação, no entanto, parece um tanto questionável, uma vez que Ponciano, na verdade, teme o sobrenatural e só nega esse fato para parecer corajoso e conquistar fama. Logo, ainda que se aceite que real e sobrenatural convivam na narrativa, não se pode dizer, necessariamente, que o insólito não provoque medo e assuste as personagens. Embora saia vitorioso ao final de suas aventuras sobrenaturais e acabe se convencendo de seu pretenso

13 A paginação indicada refere-se à versão de impressão, gerada ao salvar o artigo. 
heroísmo, Ponciano comumente se assusta no princípio, e é justamente quando tenta esconder esse fato que ele se denuncia, evidenciando seu medo.

Outro ponto importante da reflexão de Bernd, novamente amparada em Miyazaki, é o reconhecimento da figura do contador de histórias no romance. De fato, conforme se verificou, a figura antropológica do contador de histórias na ficção de José Cândido já se faz presente nas crônicas, antes de se plasmar na forma romanesca. Em O coronel e o lobisomem, a representação do contador revelaria a consciência de que a cultura popular estaria morrendo e o pensamento mágico restringindo-se ao campo:

Assim, revivendo relatos nos quais muitos já não acreditavam taxando-os de "invencionices do povo bronco dos ermos", o coronel empreende uma tentativa desesperada de preservá-los da ameaça de desaparecimento. Ao narrá-los, o coronel está, portanto, repetindo o gesto dos contadores, compelidos a exercer a memória em meio a uma população que não dominava a escrita. O gesto de preservação, contudo, é duplo: preservando a oralidade, o narrador preserva sua própria figura de coronel em vias de desaparição como as estórias que conta. (Bernd, 1998, p.6)

Entre essas "estórias" do contador Ponciano, Zilá Bernd confere maior destaque à do lobisomem, mito que a autora compara ao do zumbi na literatura francófona do Caribe. Conforme explica, o mito do lobisomem é universal, registrado desde Heródoto, e foi levado da Grécia a Portugal, para depois se espalhar para o continente americano. Mistura de lobo e homem, é um dos "animais fabulosos" mais conhecidos no mundo. Em sua essência, está a capacidade de se transformar em lobo, de se metamorfosear. A tese de Bernd é de que a transformação que está no cerne da figura do lobisomem pode simbolizar, como tema literário no Brasil e na América Latina, o caráter híbrido e de permanente metamorfose do continente americano. Segundo ela, seres híbridos como o lobisomem e o zumbi expressam a ambiguidade humana e se constituem em "bodes expiatórios da 
comunidade que, ao eliminá-los, exorciza seus medos perante o estranho e o desconhecido" (Bernd, 1998, p.11).

A autora conclui afirmando que no corpus analisado, entre romances brasileiros e caribenhos, ocorre o trânsito de duas lógicas que interagem sem se antagonizar, duas visões de mundo que são apresentadas de forma não contraditória. O efeito disso seria o abalar de certezas, proporcionando "efeitos de verdade" ao leitor, já que são várias as formas de compreender as Américas.

O que os autores visam não é a construção de uma escritura pasteurizada e previsível, ou a inscrição de formas e sentidos populares pelo mero gosto de produzir efeitos de exotismo. Creio que no bojo de seu projeto de escritura está a elaboração de uma identidade americana crioulizada ou híbrida, alicerçada no reconhecimento do outro ou estruturada com base na não hierarquização das diferenças. (Bernd, 1998, p.12)

A direção que a autora aponta, no sentido de que a absorção das formas populares pelas narrativas está associada com a construção de uma identidade americana híbrida, fornece bases para a proposição a ser feita no capítulo seguinte. Nesse sentido, pretende-se demonstrar, a seguir, como ocorre a construção de uma identidade latino-americana, em geral, e brasileira, em específico, no romance de José Cândido de Carvalho. Com efeito, conforme já se mencionou ao final da apresentação do estudo de Regina Zilberman, o romance $O$ coronel e o lobisomem permite que se visualize, na caracterização de seu protagonista, o que se poderia entender como uma espécie de retrato do Brasil da segunda metade dos anos 1950. Por essa leitura, torna-se possível indicar uma interpretação viável da função da dimensão insólita do romance, além de definir o lugar da obra tanto no contexto histórico de sua publicação, quanto na vertente regionalista da literatura brasileira, cumprindo, assim, com os intuitos propostos neste estudo e favorecendo uma atualização da fortuna crítica do romance. 


\section{3 \\ UM LOBISOMEM NA PERIFERIA DO CAPITALISMO}

\section{Ponciano somos nós}

A cultura pode ser vista como a matéria de criação do artista. Ao debruçar-se sobre a realidade, o dilema ou o absurdo, o artista lida principalmente com os elementos espirituais que manifestam ou recobrem o desafio. Lida com a cultura, com o mundo das ideias, imagens, símbolos, signos, representações, sublimações, exorcismos, fantasias. Um dos segredos da fabulação artística está em que ela desvenda o dilema e o absurdo escondidos na realidade. Há formas de vida e movimentos da história que aparecem de modo surpreendente, ou enlouquecido, quando o artista inventa possibilidades do real. O episódico, fugaz ou insólito pode revelar andamentos do todo. Neste sentido, a arte é uma forma original, privilegiada, de conhecimento.

(Ianni, 1991, p.12)

Em vários países, se não em todos, há romances que constroem a fisionomia da sociedade nacional, enquanto história, cultura, lutas sociais, vitórias, 
derrotas, façanhas. Fica bastante nítida a ressonância da nação no romance; e deste na imagem que uns e outros podem construir da nação. $\mathrm{Na}$ América Latina, o romance inventa a sociedade nacional.

(Ianni, 1991, p.51)

José Cândido de Carvalho, ao comentar sua obra, declarou, certa vez, em entrevista: "A gente só precisa partir da premissa de que a realidade supera a imaginação” (1971, p.2). De fato, jornalista desde os 16 anos, o escritor parece ter encontrado as bases para a sua criação ficcional de natureza insólita justamente na realidade de sua época. A tentativa de identificar a realidade ou o momento histórico que se plasma no romance $O$ coronel e o lobisomem poderia reportar, imediatamente, aos fenômenos políticos do coronelismo ou do golpe militar de 1964. No entanto, conforme se demonstrou, a fatura do romance é anterior a este último evento, além de que o eixo da história do coronel Ponciano já havia despontado em crônica do autor de 1958. Já a tematização do coronelismo enquanto sistema político - bastante evidente na história do coronel Ponciano, um "Oficial Superior da Guarda Nacional" - parece não dar conta de aclarar plenamente os sentidos que o romance alcança e tampouco possibilitar que se explique sua conformação estrutural de modo satisfatório. Nesse sentido, a hipótese que aqui se levanta é a de que o romance, entre outras leituras possíveis, pode ser interpretado pela capacidade de comportar uma imagem do Brasil, mais especificamente do Brasil da década de 1950. Aceitando a sugestão de Octavio Ianni, a nação repercute no romance e este, por sua vez, a reinventa.

Para compreender em que medida a figura de Ponciano pode ser tomada como uma espécie de representação do Brasil, vem a propósito resgatar, sem incorrer em determinismos ou pretender uma visão estritamente sociológica da obra, o panorama histórico imediatamente anterior ao lançamento de $O$ coronel e o lobisomem. Entre 1956 e 1961, encontrava-se em vigência o Plano de Metas. O 
programa econômico implantado pelo então presidente Juscelino Kubitschek tinha o objetivo de modernizar rapidamente o país, promovendo um surto desenvolvimentista, razão do slogan "50 anos em 5”, criado pelo poeta Augusto Frederico Schmidt. O ambicioso projeto alavancou a economia nacional por meio de um intenso investimento em industrialização, garantido tanto pelo setor público quanto pelo privado. No entanto, uma das medidas fundamentais à consolidação desse processo consistiu na abertura a investimentos diretos de capital estrangeiro. Assim, embora os objetivos dessa política de crescimento tenham sido a diminuição da importação de produtos pelo país e, com isso, a tentativa de superação da condição de subdesenvolvimento, sua implantação resultou em um alto endividamento público, gerador de um quadro de instabilidade econômica.

Ponciano pode ser compreendido em vários aspectos como um retrato desse Brasil. O pensamento fantasioso que lhe permite ver a si próprio como um herói é equiparável à imaginação que alicerçou o sonho de uma nação em um momento histórico de euforia e promessas de mudança. Os dois metros de altura do herói de José Cândido e sua propalada força e coragem são proporcionais ao gigantismo do país de maior extensão territorial do continente sul-americano e a seu alardeado potencial de crescimento econômico. E gigante também é a ingenuidade que tanto Ponciano quanto a nação por ele representada demonstram pela convicção na veracidade de seus "mágicos poderes": o discurso mítico de Ponciano e o discurso otimista do governo se voltam contra seus próprios agentes, fazendo-os crer em soluções mágicas para os problemas.

Além disso, ambos almejam a transformação: vindo de uma classe de latifundiários enfraquecidos, Ponciano precisa se integrar ao mundo urbano e a uma classe emergente de capitalistas para sobreviver, para prolongar sua existência pela constituição de uma família; o projeto de JK, por sua vez, prevê igualmente a necessidade de rompimento com o modelo agrário-exportador de matérias-primas - e, por consequência, com a elite latifundiária que o agencia -em favor de uma revolução democrático-burguesa que surge com a 
industrialização. ${ }^{1}$ Há, portanto, o objetivo de superar a condição de atraso e marginalidade em que se encontram, saindo da periferia em rumo ao centro: Ponciano está na periferia da periferia (no meio rural de um país subdesenvolvido) e o Brasil na periferia do mundo capitalista ocidental.

Nesse mesmo sentido, se Ponciano fracassa em sua tentativa de transformação, tampouco o Brasil consegue se impor ao restante do mundo, permanecendo, ao contrário, subjugado ao controle das nações hegemônicas. É a um processo de modernização reflexa (Ribeiro, 2007) que se assiste: experimentam-se apenas os efeitos reflexos do progresso alcançado pela industrialização das grandes potências. Tal é o subdesenvolvimento que, segundo Darcy Ribeiro (2007, p.41), não pode ser compreendido como uma fase de transição entre o feudalismo e o capitalismo, a qual afetaria uniformemente todos os povos imersos nesse estágio de evolução, como ocorreu na Europa: "O subdesenvolvimento é, na verdade, o resultado de processos de atualização histórica só explicáveis pela dominação externa e pelo papel constritor das classes dominantes internas, que deformam o próprio processo de renovação, transformando-o de uma crise evolutiva num trauma paralisador".

Nesse sentido, o insólito da narrativa não é uma resposta positiva a um anseio ufanista que visa a satisfazer olhares estrangeiros ávidos por exotismo, pelo contrário: a convocação do mágico à narrativa serve como instrumento de autorrevelação das fantasias nacionais, pela denúncia do caráter ilusório do progresso repentino do país, assinalando a existência de uma consciência da real precariedade das condições do momento histórico. Por essa perspectiva, o mito

1 Claudio Bojunga [20--] rebate a acusação de que tenha havido desinteresse por parte de JK pela reforma agrária: "É uma bobagem enorme quando criticam Juscelino por não ter feito reforma agrária. Existem certas coisas, em certos momentos, que estão fora do horizonte do possível. É a mesma coisa que pedir ao presidente Franklin Roosevelt, que foi um grande presidente dos Estados Unidos, que ele desse partida na campanha dos direitos civis nos anos 1930, com a Depressão. Não era possível. Tanto é que esse problema só foi se colocar nos anos 1960. É evidente que certas coisas o Juscelino não podia fazer, mas o que ele fez bastou para que a sua se tornasse uma presidência paradigmática”. 
representado não se restringe à função de instrumento de afirmação de uma elite agrária dirigente em declínio no plano nacional, como propõe Zilberman, antes é a imagem de um país rústico, selvagem e arcaico, iludido com as ideias de civilização e progresso. Ponciano é o brasileiro da segunda metade da década de 1950, seduzido pelos influxos das metrópoles e dos grandes centros e, dados a permanência da condição de subdesenvolvimento de boa parte do país e o desequilíbrio social que ainda o assola, Ponciano somos nós. Assim, o romance $O$ coronel e o lobisomem pode ser entendido como uma paródia de um Brasil periférico em seus delírios de civilização.

Mediando ocultamente a confluência das imagens desses gigantes sonhadores parece estar a figura histórica do presidente Juscelino Kubitschek (1902-1976), conhecido como homem que ousou governar com a imaginação, levando os brasileiros a viverem o sonho intenso de serem modernos e cosmopolitas. ${ }^{2}$ Primeiro presidente eleito por voto direto após a proclamação da República, JK foi o responsável pela construção de Brasília, a nova capital federal, instalada no centro geográfico do país como forma de promover o desenvolvimento do interior, distribuindo a hegemonia litorânea ao oeste e expandindo, com isso, os núcleos de influência do território nacional. $\mathrm{O}$ projeto já estava previsto em constituições brasileiras

2 Para mais concretamente recuperar o que foi a atuação de JK na presidência, convém expor um balanço de seu governo: "Durante os cinco anos do governo Kubitschek, o produto interno bruto (PIB) cresceu à média anual de 7\%, contra os $5,2 \%$ do período de 1945 a 1955 . O PIB industrial foi ainda mais expressivo: $10,7 \%$ ao ano, em média. A produção industrial cresceu $80 \%$, a siderurgia, $100 \%$, a indústria mecânica, $125 \%$, a elétrica e de comunicações, $300 \%$, e o setor de transportes em espetaculares $600 \%$. A inflação média anual, de 24,7\%, seria desprezível diante dos patamares que alcançaria no futuro. O governo JK construiu 20 mil quilômetros de estradas e pavimentou 5.600 quilômetros de rodovias já existentes, literalmente abrindo caminhos para a nascente indústria automobilística nacional. Implantou a indústria da construção naval e elevou a produção de petróleo de 6.800 para 100 mil barris diários. Construiu a refinaria Duque de Caxias - e as hidrelétricas de Três Marias e Furnas, aumentando a potência total instalada de 3 milhões de $\mathrm{kW}$, em 1954, para 4,7 milhões no final do quinquênio. Criou ainda a Sudene, para promover o desenvolvimento do Nordeste, e a Comissão Nacional de Energia Nuclear” (Werneck, 2002). 
anteriores, mas era sempre postergado pelos outros governantes. A construção de Brasília, obra liderada pelos arquitetos Lúcio Costa e Oscar Niemeyer, terminou em um tempo recorde de 41 meses e se tornou reconhecida como uma das maiores façanhas da história brasileira do século XX. Por realizações dessa magnitude, JK foi homenageado como "o brasileiro do século", em uma eleição divulgada pela revista Istoé em 1999, para indicar figuras brasileiras de maior destaque do século XX: "Com líderes como esse, não temos o que temer, pois somos capazes, como povo, de seguirmos adiante. Pedimos a JK que continue a nos inspirar", afirmou, na ocasião, o então presidente Fernando Henrique Cardoso. ${ }^{3}$

Sem a compreensão do carisma despertado por essa figura histórica (e quase mitológica), a confessa simpatia de José Cândido de Carvalho por Juscelino Kubitschek poderia, em um primeiro momento, parecer contraditória a seus valores, uma vez que o escritor professava uma profunda aversão ao progresso.

Para melhor esclarecer essa questão é preciso lembrar que José Cândido chegou a fundar a Sociedade dos Inimigos do Progresso: a proposta, aparentemente absurda, pretendia-se séria e contava, ainda, com a adesão de escritores como Rachel de Queiroz, presidente da sociedade, e Carlos Drummond de Andrade, que participaria como patrono. O Jornal do Brasil, de 23 de janeiro de 1975 (1 ${ }^{\circ}$ Caderno, Nacional, p.17) noticiava: "Escritores no Rio preparam criação de sociedade para lutar contra o progresso". A informação era que José Cândido pronunciaria, naquele dia, um discurso na ABL apresentando o manifesto do programa. A intenção do grupo era discutir os efeitos maléficos do desenvolvimento para o bem-estar do homem. Alceu Amoroso Lima, sob o pseudônimo de Tristão de Athaíde, refere-se à associação, no artigo "Uma cultura agonizante" (Jornal do Brasil, 28 fev. 1975, $1^{\circ}$ Caderno, p.6), como uma sociedade simbólica, mas José Cândido afirmava, por certo um tanto jocosamente, tratar-se de uma sociedade "com estatuto, reuniões e diretoria" (Carvalho, 1975, p.1). Embora o projeto pareça não ter sido levado

3 Cf. O brasileiro do século. Istoé, São Paulo, n.1.577, 22 dez. 99. 
a cabo, José Cândido afirmava, ainda depois de alguns anos, sua necessidade. Ser um inimigo do progresso era-lhe, na verdade, uma ideia fixa, já que seu próprio estilo de vida condizia com o objetivo da projetada Sociedade. Os trechos a seguir são partes de entrevistas concedidas nos anos de 1977 e 1979, respectivamente, e demonstram bem essa sua obsessão:

Sempre achei que o progresso atrasa a vida. O mundo vai se desfigurando por ele. Há aparelhos para tudo, até para tirar cera do ouvido. As cidades modernas não foram feitas para gente de carne e osso. (Carvalho, 2004, p.132)

Se eu pudesse, andava de pincenê, polainas, bengala ou guarda-chuva. Dava um chute no mais aristocrático automóvel e fazia a gasolina retornar, pelo mesmo cano que a descobriu, às profundezas. (Carvalho, 2004, p.134)

Moro em Niterói, numa chácara, e não tenho carro. A vida hoje é para o automóvel, não para as pessoas. $\mathrm{O}$ amor que era na porta, hoje é na Barra. Tenho esperança que isso vá acabar porque a gasolina está acabando. Espero que inventem algo bem pior para que todos andem a 20 quilômetros. A Rachel de Queiroz queria fundar a Sociedade dos Inimigos do Progresso. Acho que a ideia deve ser retomada, porque senão até a lua vai ser loteada. As minhas viagens são, no máximo, para Niterói. Sou o Marco Polo de Niterói. Quando vou a outro estado, tiro passaporte. Sou filho de portugueses, tradicionais navegantes, mas não sou um viajor. (Carvalho, 1979, p.4)

Esse posicionamento de José Cândido perante a modernidade torna-se complexo quando posto ao lado de sua estima pela figura de JK, o grande impulsionador da industrialização brasileira. A maior demonstração dessa admiração aparece, em sua obra, no texto "O futuro manda lembranças", parte do livro de entrevistas criativas, ou "retratos 3 x 4" como prefere designá-las, Ninguém mata o arco-íris. O livro foi publicado em 1972, mas o texto de seis páginas em que busca retratar JK, fixando-o em um "arco-íris" de personalidades a serem eternizadas, data de 3 de agosto de 1968, 
conforme informação constante da obra. "Minhas viagens em torno dos outros" é como José Cândido define o teor pessoal do mosaico de retratos que constrói no livro (Carvalho, 1972, p.xii). Eduardo Portella demonstra ter compreendido bem o espírito da publicação ao prefaciá-la com um pequeno texto intitulado "Desta vez, a mitologia urbana”. De fato, a viagem de José Cândido em torno da figura histórica de JK no livro acaba por acentuar os contornos míticos do presidente. Prova disto é que o escritor (Carvalho, 1972, p.156) inicia o delineamento do retratado do seguinte modo: "Nunca perdeu tempo em miúdas faxinas de ódio ou ressentimentos. Construiu uma cidade e mudou o jeito deste país. É lendário e histórico. É JK”. Tal texto, um primor pela condensação de sentidos das descrições imagéticas, merece ser comentado para dar concretude à possibilidade de leitura, que aqui se apresenta, do romance O coronel e o lobisomem.

Depois desse pequeno preâmbulo, o texto divide-se em doze subdivisões ou pequenos flashes, de apenas um parágrafo em sua maioria. No primeiro fragmento, "Lenda em óculos e paletó" - imagem de uma mitologia urbana de que fala Portella - José Cândido de Carvalho (Carvalho, 1972, p.156) apresenta o contexto em que se realizou a entrevista: Rio de Janeiro, residência do ex-presidente mineiro, em dia chuvoso, "bom tempo para conversinha mineira, em recanto de sala, bem fumada e bem cafezada”. E, já afirmando sua admiração por essa figura equiparável a um país inteiro, declara: "Viajo por essa fabulosa nação que é JK em pessoa. Dependurado em seu fascínio" (Carvalho, 1972, p.156, grifos nossos).

O próximo quadro, "Luar para exportação", retoma o cenário da infância de JK. É a trajetória do natural ao artificial: Diamantina, os confins de Minas Gerais em uma época desprovida dos confortos da modernidade, inclusive, da luz elétrica. Não por acaso o biógrafo destaca a beleza do luar que ilumina Diamantina e suas adjacências. Mas o tom lírico logo se desfaz em gracejo: "Quando chega agosto, que é mês de vento e desgosto, o luar de Diamantina está maduro para ser encaixotado e exportado" (Carvalho, 1972, p.156). A referência ao mês de agosto - mote da ficção insólita de José Cândido 
- indicaria, portanto, um tempo ideal para se "exportar o luar". Note-se a fusão de elementos díspares, criando um efeito poético pela estranheza das associações: um luar "maduro", elemento abstrato, impalpável, caracterizado como uma fruta a ser encaixotada e exportada. A imagem alude à política econômica adotada pelo governo JK, de diminuição da importação de produtos estrangeiros em favor da exportação de produtos nacionais.

Cada detalhe do texto, aliás, é significativo ao fazer referência a um dado histórico, como ocorre na seguinte construção: "Não é vantagem fazer serenata em Diamantina. Se o instrumento é desafinado, se a voz é empenada, o luar pega logo o violão e canta suas cantorias antigas, como aquela do peixe vivo que não pode viver fora da água fria" (Carvalho, 1972, p.156). A cena evoca o tipo de paisagem e a atmosfera que o campo assume na ficção de José Cândido; mas, mais que isso, a menção à "serenata", às "cantorias antigas" e à canção popular do peixe vivo são referências diretas a símbolos que identificavam a figura de JK: "Filho de Diamantina, adorava serenata, em especial quando se cantava o 'Peixe vivo', canção folclórica que acabou se convertendo em uma espécie de hino com que Juscelino era saudado em toda parte" (Werneck, 2002). Há ainda referência a uma "serenata da melhor marca mineira" que teria sido oferecida a JK, "com milhares e milhares de figurantes [...]. Um comício de gente" (Carvalho, 1972, p.156). As imagens podem ser alusão à Frente Ampla, grupo político criado em 1966, que reuniu as maiores lideranças civis do país, Carlos Lacerda, JK e João Goulart, com o intuito de se opor ao Regime Militar instalado em 1964. A Frente Ampla se tornaria a maior manifestação operária do país e, por isso, em abril de 1968, foi proscrita pelo governo ditatorial, o que levou JK a abandonar a política. Daí o texto de José Cândido afirmar que depois da enorme serenata, JK quer organizar outra "em tom menor. [...] Com o luar por companheiro” (Carvalho, 1972, p.158). Como a entrevista é publicada em agosto de 1968 e o narrador afirma ser este um fato recente, a explicação adquire plausibilidade. $\mathrm{O}$ que entrevistador e entrevistado não sabiam é que meses depois, em dezembro, JK seria preso com o decreto do AI-5. 
No frame seguinte, "Diamantina intocável”, o "político mais simpático da história do Brasil”, como o descreveu Carlos Lacerda, assim aparece: "Com um pé no sapato e outro no chinelo, JK ri do luarão de sua terra. Dizendo assim: - É da melhor marca nacional." (Carvalho, 1972, p.158). A cena de fortuita não tem nada. Um pé no sapato e outro no chinelo é uma imagem que por si só basta para indicar um misto de seriedade e descontração na personalidade do presidente, no entanto, ele de fato tinha por hábito descalçar os sapatos quando sentado. E foi em uma dessas ocasiões, mais especificamente quando em companhia de uma atriz norte-americana, que um fotógrafo o flagrou, registrando uma imagem que inspirou, inclusive, Nelson Rodrigues a escrever "Descalço com Kim Novak":

[...] Ninguém mais antipresidencial. Ele trouxe a gargalhada para a presidência. Nenhum outro chefe de Estado, no Brasil, teve essa capacidade de rir - e nos momentos mais inoportunos, menos indicados. Dir-se-ia que ele tinha sempre um riso no bolso, riso que ele puxava, escandalosamente, nas cerimônias mais enfáticas. Os outros presidentes têm sempre a rigidez de quem ouve o Hino $\mathrm{Na}$ cional. Cada qual se comporta como se fosse a estátua de si mesmo. Não Juscelino. Quando ele tirou os sapatos para Kim Novak (que achado genial! que piada miguelangesca!), ele foi o antipresidente, uma espécie de cafajeste dionisíaco. Eu diria que jamais alguém foi tão brasileiro. O novo Brasil é justamente isso: - um presidente que tira os sapatos para uma beleza mundial. (Jornal Brasil em Marcha, 10 fev. 1961)

Como não poderia deixar de ser, na ficção de José Cândido, ao lado do riso, o sobrenatural marca presença no quadro "Os fantasmas andam de noite". O escritor teria perguntado: "Presidente, como anda Diamantina em matéria de assombração?”. A partir disso, a cena que se desenrola parece ser uma variação de alguns episódios da vida de Ponciano. Diante da indagação, JK não ri - leva a sério assunto de assombração - e para responder retorna ao tempo de menino. Agora JK é o contador de histórias: 
E regressa de lá [de "suas noites de calças curtas"] com um personagem enluarado, um certo cavaleiro que foi morto em perdidos anos e que teimou em não falecer. Ficou encantado, vivendo mais do que em seus dias de carne e osso. Comenta o bom humor de Juscelino:

- Que fantasma de castelo inglês, que nada! Assombração para o meu gosto só a do mineiro de Diamantina.

E relata, de óculos em punho, ser o enfeitiçado das noites de Diamantina um fantasma andador. Pontual, saía sempre na hora certa, no ponteiro da meia-noite. Navegando em pata de cavalo. E era em pata de cavalo que atravessava a cidade para desaparecerem na noite do sertão. JK recorda:

- Embaixo dos cobertores, enrolado de medo, a gente via, sem olhos, o cavaleiro passar em seu galope encantado.

O cavaleiro da noite! Muitas vezes, no Catete ou no Alvorada, em Nova Iorque ou em Paris, no poder ou no exílio, Kubitschek ouviu seus perdidos passos. Melhor, vai ouvir esse tropel a vida toda. Enquanto tiver um coração de menino. (Carvalho, 1972, p.158-9)

Tanto a caracterização de JK como contador de histórias com "coração de menino", quanto a descrição do cavaleiro falecido que continua a perambular pelo mundo em "galope encantado" remetem imediatamente à atmosfera de $O$ coronel e o lobisomem: igualmente contador de histórias de coração infantil, Ponciano também fica em estado de encantamento, quando se depara com uma sereia:

Aí ponderei:

- Ponciano está encantado.

Em verdade, o coronel não deliberava mais. Nem sentia o barulho do mar, nem o vento da costa. Tudo escureceu como noite sem lua fosse. Na unha do encanto eu valia menos que um jacá furado ou agulha partida. Achei tudo isso uma falta de respeito que ofendia meu brio militar. (Carvalho, 1983, p.106) 
A semelhança é ainda mais notável ao final do romance, quando o coronel Ponciano, morto, ainda sai montado em sua "mulinha de desencantar lobisomem", para o conflito final, ou talvez eterno, a "guerra do demônio" (Carvalho, 1983, p.303): "Em pata de nuvem, mais por cima dos arvoredos do que um passarinho, comecei a galopar. Embaixo da sela passavam os banhados, os currais, tudo que não tinha mais serventia para quem ia travar luta mortal contra o pai de todas as maldades" (Carvalho, 1983, p.304).

Depois de retirar os óculos para revirar suas memórias do sertão mineiro assombrado, JK os coloca novamente "para melhor ver o futuro" (Carvalho, 1972, p.159), no quadro "O futuro manda lembranças", que confere título ao texto. Em 1968, ano da entrevista, é para o ano 2000 que ele dirige seu olhar de otimismo: "As antenas de JK dizem que será um tempo bom, mais igual e mais amigo. [...] Os grandes desencontros e contradições dos nossos dias terão desaparecido. Serão memórias de um tempo de procura e transição" (Carvalho, 1972, p.159). A solução para isso poderia ser encontrada na França, como explica Kubitschek, nação antiga, com uma "respeitável certidão de idade" de mais de 2 mil anos. Focaliza-se, portanto, o centro irradiador da cultura europeia. Para o eterno otimista o futuro já teria começado, "andando nas pernas de suas máquinas maravilhosas”, mas máquinas que, José Cândido alerta, "arquivaram, como antiguidades de museu, os contos mais arrojados das Mil e uma noites" (Carvalho, 1972, p.159). E, com essa imagem do conflito entre modernidade e tradição, em que esta é soterrada por aquela, encerra-se esse sketch.

Em "Político, esse desconhecido", o biógrafo apresenta a opinião de JK de que os políticos brasileiros muitas vezes são mal compreendidos, mal interpretados. No cenário da política nacional, são citados Osvaldo Aranha e Antônio Carlos, como personalidades que JK admira, exclamando: "-Verdadeiramente sedutores, representantes de um Brasil cordial e amável. Um Brasil de primeira ordem”. E o biógrafo endossa: "Criaturas esplêndidas! [...] Em suas mãos a política era realmente uma arte de bom gosto. Uma flor de civilização" (Carvalho, 1972, p.160). Em “Orquídeas nas nuvens”, o tema da 
política permanece: faz-se uma crítica, da perspectiva de JK, aos especialistas, técnicos, economistas que, para ele, nada entenderiam de política, cuja exigência é "formação em povo". Assim, enquanto os políticos seriam os jardineiros, os técnicos seriam, por sua vez, com seus papéis, gráficos e um dialeto próprio e incompreensível, os botânicos, de modo que "Alguns cultivam orquídeas nas nuvens" (Carvalho, 1972, p.160), ou seja, seus conhecimentos teóricos e abstrações não têm proveito real e prático para o exercício de um governo. Está dada, portanto, mais uma faceta de JK: o populismo. Com efeito, "Juscelino reduziu a distância entre o presidente e os brasileiros”, afirma Claudio Bojunga (apud Werneck, 2002), autor de uma biografia de JK.

Nos fragmentos "Os audaciosos" e "Três para a história", fala-se do entusiasmo de JK para com os "homens audazes, os que sacodem as nações e dão novos destinos à vida", como os pioneiros "que espicharam o Brasil", pois "não foi atrás de escrivaninhas, fazendo torrinhas de números que o Brasil cresceu”. E, nesse sentido, JK cita três personagens que teriam visto o país para além de seu tempo: "D. João VI, Mauá e Vargas” (Carvalho, 1972, p.161). Na continuação, depois de uma referência ao livro de memórias que JK produzia, Meu caminho até Brasília, no quadro "A lavoura do tempo", retorna a figura do contador de histórias em "O impossível também acontece". O flash incorpora uma anedota ao remontar uma situação em que Juscelino, católico, conta uma piada ridicularizando o protestantismo. "Entre os livros e a vida", último fragmento, narra o contexto de término da entrevista: enquanto Juscelino atende a uma ligação telefônica, José Cândido observa os livros em seu escritório: sobre a mesa, dois romances, um de Jorge Amado e outro de Josué Montello, e uma biografia do Barão do Rio Branco. Nas paredes, aquarelas com as paisagens de Minas de céu muito azul: "Cores de Minas para os olhos castanhos e para o grande coração de JK" (Carvalho, 1972, p.162).

Esse retrato de Juscelino Kubitschek, e também de uma época, feito por José Cândido, acaba por iluminar a caracterização do herói Ponciano e ampliar os sentidos que a trama pode adquirir em face do 
contexto histórico desenvolvimentista de criação do romance. Para aceitar que Ponciano é uma representação do Brasil de meados do século XX é preciso, antes, passar pela figura histórica e lendária de Juscelino Kubitschek no exercício da presidência e também pelo modo como a compreendeu José Cândido. A figura histórica de Kubitschek e a fictícia de Ponciano fixam-se nas páginas do escritor por contornos míticos, lendários, próximos em suas características. Se Ponciano não é uma paródia da figura específica de Juscelino, ao menos é uma representação dos desejos de uma nação que sobre esse presidente se projetaram. Como herói nacional, JK se firmou no imaginário popular como uma figura que, por seus contornos gerais, aproxima-se da criação de José Cândido na personagem do coronel Ponciano. Assim, muito do que se falou a respeito do temperamento do homem $\mathrm{JK}^{4}$ corresponde, em alguma medida, à caracterização do coronel:

"Era fácil criticar JK. O difícil, o impossível, era não gostar dele." (Carlos Lacerda)

"A marca mais forte da sua grandeza foi a imaginação." (Carlos Lacerda)

"O presidente Juscelino era antes de mais nada um ser humano, um homo sapiens, um cidadão que atuava levado por seu coração." (Henrique Teixeira Lott)

"JK sabia ser galante, e não só com as mulheres - afinal, dizia Rubem Braga, a política era a arte de namorar homem." (Claudio Bojunga)

"Juscelino olhava e tratava os seus semelhantes com o respeito e a ternura dos que sentem, dos que sabem, dos que são." (Vera Brant)

"JK alcançou o que poucos estadistas alcançam: criar uma nova identidade nacional." (Fernando Henrique Cardoso)

"A partir de Juscelino, surge um novo brasileiro." (Nelson Rodrigues)

4 Essas definições de Juscelino Kubitschek foram extraídas do site do Projeto Memória, que o homenageou com uma biografia em seu centenário, comemorado em 2002, numa realização da Fundação Banco do Brasil e Odebrecht. Cf. http://www.projetomemoria.art.br/JK/. 
Nesse sentido, Ponciano pode ser entendido como o novo brasileiro, esperançoso, sonhador, que acredita na transformação, que acredita ser possível se inscrever na modernidade, buscando para si um novo perfil, uma nova identidade. Juscelino dizia "Deus poupou-me o sentimento do medo", e é desse modo que Ponciano tenta se afirmar por sua coragem, muito embora, na prática, fracasse, como que revelando também em sua figura o fim de uma época de sonhos e projetos. "Todas essas proezas que aconteceram na segunda metade da década de 1950 foram muito inspiradas por essa ideia de que o Brasil podia dar certo. Foi uma época marcada pela imaginação", afirma Cláudio Bojunga [20--]. Assim, a ira de José Cândido contra o progresso decorre, certamente, de sua frustração ao reconhecer que os esforços para obtê-lo, na esperança de que tudo pudesse melhorar, eram vãos. Logo, não é exatamente contra aqueles que sonharam com um país melhor pela tentativa de participar do progresso que o escritor se indispõe: é justamente contra a ilusão criada pelo progresso numa nação periférica. Mais do que o reflexo de um momento da história nacional, seu romance é, portanto, uma crítica a esse momento, uma forma de revelá-lo além do aparente, é a tomada de consciência, de um ponto de vista interno, da precariedade das condições do país, e a revolta contra a mecanização e a padronização do mundo.

Assim, a crítica construída nessa ficção dirige-se às consequências de um progresso que só pode ser parcial, que só pode se fazer gerando exclusão, desequilíbrios e desigualdade social. O fenômeno que José Cândido critica no romance $O$ coronel e o lobisomem é a condição de subdesenvolvimento ou ainda a situação de "modernização reflexa" por que passa o país, como Darcy Ribeiro (2007) explicaria em 1970. O Brasil, como outros países das Américas, só pôde experimentar os reflexos de uma modernização que se deu em países ricos do hemisfério norte, e esse seria o motivo do desenvolvimento desigual dos povos latino-americanos. Nesse contexto, a dimensão insólita e fantasiosa do romance exerce, para o protagonista, a função de mecanismo de compensação de uma expectativa irrealizada de mudança, enquanto que, para o leitor, surge como a denúncia da 
impossibilidade de melhorias, revelando, sob um olhar de extremo pessimismo, o caráter utópico dessa esperança. Dessa forma, o conflito entre modernização e atraso verificado no plano temático da narrativa exige uma saída formal encontrada no nível do insólito. É pelo insólito, portanto, que a realidade do subdesenvolvimento se revela.

Se se aceitar que o romance de José Cândido, enquanto arte literária, cumpre com uma função para além da mera gratuidade e entretenimento, esta seria certamente a de proporcionar uma forma de conhecimento privilegiado acerca da realidade de sua época. Conforme afirmou Antonio Candido (2002, p.85-6), em vista das relações entre literatura e sociedade, "podemos abordar o problema da função da literatura como representação de uma dada realidade social e humana, que faculta maior inteligibilidade com relação a esta realidade". Assim, os sentidos do romance se ampliam em função de seu contexto histórico, ao mesmo tempo que, inversamente, a leitura da obra se torna uma forma poderosa de compreender a realidade pelo olhar crítico de um escritor que sobre ela se projeta para revelá-la (ou reinventá-la) ficcionalmente.

\section{Subdesenvolvimento e literatura regionalista}

Aqui tudo parece que é ainda construção e já é ruína.

Caetano Veloso

É de Antonio Candido (2002) a ideia - necessária para esse ponto da discussão - de que a literatura regionalista seja tributária da condição de subdesenvolvimento de um país. Por essa relação, pode-se compreender melhor o vínculo entre a crítica social existente no romance de José Cândido de Carvalho e a tradição literária a que ele pertence. A noção de regionalismo na obra de Antonio Candido mostra-se, porém, cambiante e complexa, seja em função da diversidade de produções que o termo abrangeu, seja pelo momento histórico em que o crítico se inscreve. Em todo caso, isso exige um olhar 
cauteloso para as nuances que o conceito adquire em seus estudos, antes de transportá-lo a um romance que não integra diretamente o corpus ao qual o autor se dedica.

Desse modo, deve-se lembrar que Antonio Candido demonstrou, em certos momentos, resistência em reconhecer a qualidade de algumas obras identificadas sob esse rótulo. Em Formação da literatura brasileira, de 1959, embora sustente ser o regionalismo um fator decisivo para a autonomia da literatura nacional, Candido (2006) critica duramente o que se entende por regionalismo pós-romântico, o praticado por Afonso Arinos, Simões Lopes Neto, Valdomiro Silveira, Coelho Neto e Monteiro Lobato. Enquanto escritores do Romantismo, como José de Alencar, Bernardo Guimarães, Franklin Távora e Visconde de Taunay, teriam produzido obras regionalistas de valor, por nelas preponderarem os problemas humanos ao espaço, o outro grupo de autores (também conhecidos como pré-modernistas) teria incorrido no exotismo e eliminado a humanidade das personagens:

Já o regionalismo pós-romântico dos citados escritores tende a anular o aspecto humano, em benefício de um pitoresco que se estende também à fala e ao gesto, tratando o homem como peça da paisagem, envolvendo ambos no mesmo tom de exotismo. É uma verdadeira alienação do homem dentro da literatura, uma reificação da sua substância espiritual, até pô-lo no mesmo pé que as árvores e os cavalos, para deleite estético do homem da cidade. Não é à-toa que a "Literatura sertaneja" (bem versada apesar de tudo por aqueles mestres), deu lugar à pior subliteratura de que há notícia em nossa história, invadindo a sensibilidade do leitor mediano como praga nefasta [...]. (Candido, 2006, p.528)

A voz subjacente à argumentação de Antonio Candido é por ele revelada quando menciona Lúcia Miguel-Pereira para endossar a ideia da autora de que, mesmo aos românticos, que bem trabalharam o regionalismo conferindo humanidade às personagens, faltaria o aprofundamento de uma "pesquisa psicológica". Para se ter uma 
ideia do que significa essa influência sobre o parecer de Candido, é válido recorrer ao artigo "Regionalismo e história da literatura: quem é o vilão da história?”, de Marisa Lajolo. Nele, ao analisar o tratamento dispensado ao regionalismo ao longo da historiografia literária brasileira, Lajolo (2007) utiliza a expressão "banho de mau humor" para sintetizar a visão negativa de Lúcia Miguel-Pereira sobre o assunto. A postura da autora de Prosa de ficção, livro de 1950, seria um dos marcos para a fixação da conotação pejorativa que o termo adquiriu na crítica nacional. Marisa Lajolo, porém, demonstra que o juízo de valor de Lúcia acaba por dizer mais respeito ao lugar crítico a partir do qual fala (discurso intelectual urbano), revelando os preconceitos daí decorrentes, do que à ficção regionalista que tenta inferiorizar:

[...] os preconceitos com que a crítica e a história literária brasileiras lidam com o regionalismo podem desvelar seus contornos ideológicos e sua dimensão política: seus protocolos de leitura literária são urbanos e ortodoxos e talvez codifiquem, no rótulo regionalismo/ regionalista, sua incapacidade de dar conta do modo de ser mestiço da literatura regionalista que, produtor cultural crioulo como o país, é carimbado como estrangeiro pelos olhos urbanos e europeizados da crítica [...]. (Lajolo, 2007, p.327)

De fato, Antonio Candido compartilha por vezes dessa perspectiva alvo da crítica de Lajolo e parece tomar o binômio regional/ urbano como correspondente simétrico a particular/universal, no sentido da validade estética e do alcance da significação das obras. Observe-se que não se trata de questionar aqui a pertinência da reflexão sobre o movimento de complementariedade entre o aproveitamento de sugestões estrangeiras e a busca de recursos no próprio legado local - dinâmica que é, de fato, constitutiva da literatura brasileira e que o crítico logo reconheceu. Um tanto incômodo na crítica de Antonio Candido, na perspectiva atual, é perceber que o tratamento dado ao regionalismo parece estar ainda contaminado por uma compreensão, até certo ponto, negativa do termo. Isso ocorre, 
sobretudo, quando o autor em vez de pensá-lo em contraposição ao cosmopolitismo, como parece adequado, opõe-no ao que costuma denominar "universalismo", sugerindo que a validade estética da obra poderia estar comprometida em função do traço local.

Desse modo, quando o crítico se vê impelido a ter de aceitar a existência da dimensão regional de uma determinada obra, se a considera bem realizada, trata logo de ressaltar que essa particularidade atua em favor de algum outro aspecto mais relevante, que a tornaria válida universalmente e significativa para homens de qualquer tempo e lugar. Essa tendência de justificar a natureza regionalista das obras, como se vendo na necessidade de explicar que "apesar de regionalistas" seriam produções de qualidade, leva-o a quase negar tal dimensão na prosa de Guimarães Rosa. Daí o crítico afirmar, em 1946, quando do lançamento de Sagarana:

[...] Sagarana não vale apenas na medida em que nos traz um certo sabor regional, mas na medida em que constrói um certo sabor regional, isto é, em que transcende a região. A província do Sr. Guimarães Rosa, no caso Minas, é menos uma região do Brasil do que uma região da arte, com detalhes e locuções e vocabulário e geografia cosidos de maneira por vezes quase irreal, tamanha é a concentração com que trabalha o autor. [...] Por isso, sustento, e sustentarei, mesmo que provem o meu erro, que Sagarana não é um livro regional como os outros, porque não existe região igual à sua, criada livremente pelo autor com elementos caçados analiticamente e, depois, sintetizados na ecologia belíssima das suas histórias. [...] Sagarana nasceu universal pelo alcance e pela coesão da fatura. (Candido, 2002, p.185-6, grifos do autor)

O mesmo posicionamento se verifica quando da publicação de Grande sertão: veredas, no ensaio "O homem dos avessos", de 1957:

A experiência documentária de Guimarães Rosa, a observação da vida sertaneja, a paixão pela coisa e pelo nome da coisa, a capacidade de entrar na psicologia do rústico - tudo se transformou em 
significado universal graças à invenção, que subtrai o livro à matriz regional para fazê-lo exprimir os grandes lugares comuns, sem os quais a arte não sobrevive: dor, júbilo, ódio, amor, morte - para cuja órbita nos arrasta a cada instante, mostrando que o pitoresco é acessório e que na verdade o Sertão é o Mundo. (Candido, 1978, p.122, grifo nosso)

A ideia de "transcendência da região" se mostra eficiente na medida em que evidencia o potencial simbólico da prosa rosiana, talvez recurso que o crítico chame, no primeiro excerto, de "concentração". Com efeito, na prosa poética do escritor mineiro, as referências espaciais vão muito além do dado concreto e os sentidos condensam-se, potencializando-se. No entanto, a espacialidade rural, sertaneja, como matriz de onde emanam os sentidos, não deve ser ignorada, tampouco tomada em oposição a um outro tipo de geografia que por si só pudesse ter "valor universal". O preconceito enraizado nessa desconfiança para com o regionalismo decorre de uma generalização das fragilidades apresentadas por parte da produção assim classificada, uma vez que muitas obras foram acusadas de exóticas, pitorescas e artificiais. No entanto, a tendência da crítica de "subtrair a prosa de Guimarães Rosa à matriz regional” prejudica a compreensão de diálogos que se estabelecem no interior da tradição regionalista brasileira. Isso é o que defende o pesquisador André Tessaro Pelinser (2010, p.119) ao constatar certo "apagamento", por parte da crítica, das marcas regionais de autores consagrados, como ocorre com a obra de Guimarães Rosa ao ser vista principalmente em relação a escritores do cânone internacional: "possivelmente nossa historiografia tenha optado por estreitar os laços com os grandes nomes da prosa mundial em lugar dos regionalistas brasileiros, aprofundando ainda mais o fosso de uma classificação pertinente e desprovida de preconceitos para com o regionalismo".

Além disso, de um ponto de vista teórico, complemente-se que julgar um texto como sendo ou não literatura - enquanto texto artístico, com valor estético - é algo um tanto arbitrário, dependendo de uma série de convenções que cooperam para a atribuição de valor 
a uma obra. Segundo Terry Eagleton (2003, p.22), as obras não possuem um valor imanente, pois os juízos de valor são historicamente variáveis e atribuídos em função das mudanças da sociedade. Nesse sentido, várias instâncias são responsáveis pela legitimação do caráter artístico de um texto, como o mercado editorial, a crítica literária, a academia e o público. Assim, defende-se aqui apenas certo redimensionamento da questão: o caráter "universal" que possa ter uma obra regionalista não se alcança "apesar" do regional - como, por vezes, se leva a crer - mas "por meio" dele, por um trabalho estético com ele - caráter determinado ainda por uma série de fatores externos que ditarão a qualidade do texto, sendo os juízos passíveis de revisão futura.

De volta a Candido, conforme avaliou sarcasticamente Marisa Lajolo (2007, p.322), "o mestre é pouco paciente com histórias do sertão, sendo várias as passagens em que, com severidade, acusa-as de crime de lesa-literatura [...]”. Nesse sentido, é também interessante notar que a linhagem da literatura regionalista (a "literatura sertaneja") condenada pelo crítico em Formação é justamente aquela de que o próprio Guimarães Rosa se declara continuador, ao exigir que, na orelha da primeira edição de Corpo de Baile, de 1956, se reproduzisse integralmente um conto de seu conterrâneo Afonso Arinos ("Buriti perdido", de Pelo sertão). ${ }^{5}$ Desse modo, a questão da

5 Mônica Fernanda Rodrigues Gama (2013), em sua tese de doutorado, analisa a participação de Guimarães Rosa na elaboração da orelha dos volumes de Corpo de baile, publicados pela José Olympio em 1956. Procurando as figurações do autor em sua obra, a pesquisadora recupera um manuscrito de Guimarães Rosa, do acervo José Olympio da Biblioteca Nacional do Rio de Janeiro, que introduziria o conto de Afonso Arinos na orelha do primeiro volume de Corpo de baile: "Aqui - em tenção de homenagem - o autor quis que se transcrevesse a oração do mestre Affonso Arinos à Palmeira totêmica” (Rosa apud Gama, 2013, p.160). Para a publicação definitiva, no entanto, utilizou-se como introdução ao conto de Arinos um texto em que, em lugar da figura do homenageado, se destaca sobretudo um motivo comum à obra dos dois escritores: "O buriti é um motivo constante neste livro. Quase um personagem. Por isso, em vez de se inserirem aqui os dados biográficos acerca do autor, preferiu este que se falasse da palmeira a que Affonso Arinos consagrou a admirável página. E que melhor maneira de fazê-lo, senão transcrevendo-a?” (Rosa apud Gama, 2013, p.158). 
tradição em que se inscreve Guimarães Rosa parece estar mais definida e aceita por ele mesmo do que pela crítica que, por vezes, tende ainda a desvinculá-lo de uma linhagem de autores regionalistas para transportá-lo automaticamente ao que seria uma prosa "universal". Com isso, percebe-se que não foi apenas a literatura brasileira que se construiu em torno do conflito entre o dado local e o importado na busca da formulação de uma identidade nacional e da autonomia criadora, a própria crítica se viu às voltas com essa questão. Quer-se dizer, portanto, que também causou surpresa à crítica reconhecer que uma literatura oriunda de elementos de uma realidade local/ rural/interiorana brasileira pudesse gerar um produto de valor estético universal, equiparável às obras-primas de literaturas plenamente consolidadas. Conforme constatou Lajolo (2007), o binômio regional/urbano foi inscrito, ao longo da historiografia e da crítica literária brasileiras, na antinomia particular/universal, em um movimento de desvalorização de textos que não fizeram da cidade moderna sua matriz de inspiração ou da narrativa urbana um padrão de linguagem.

Antonio Candido parece conceder maior atenção ao regionalismo - também em sua manifestação na literatura pré-modernista - em publicações que surgem na década de 1970, época em que já estabelecera contato com o crítico uruguaio Ángel Rama. O ensaio que marca esse novo enfoque é "Literatura e subdesenvolvimento", texto produzido, justamente, a pedido de Rama, para compor o volume America latina en su literatura, publicado em 1972. ${ }^{6}$ Em entrevista a Pablo Rocca, o próprio Antonio Candido (2009, p.24) explicou que, em 1968, em uma reunião cujo propósito era definir os tópicos do livro e seus respectivos autores, Rama indicou seu nome para o tema "Literatura y subdesarrollo": "[...] aceitei a contragosto, porque achei a tarefa muito superior às minhas possibilidades. [...] Posso dizer que foi o artigo mais trabalhoso que escrevi. Labutei nele doze

6 "Literatura e subdesenvolvimento" antes de aparecer em 1972, no volume ao qual se destinava, foi traduzido para o francês e publicado também na revista Cahiers d'Histoire Mondiale, em 1970 (Candido, 1989, p.216). 
meses para me ajustar ao assunto difícil e reunir as informações, mas nesse processo aprofundei bastante o conhecimento".

Segundo Gonzalo Aguilar (2005), esse artigo significou uma nova etapa da crítica de Antonio Candido, pois foi a partir dele que o intelectual brasileiro começou a manifestar um crescente interesse pela América Latina, tanto no campo da literatura quanto no da política. Depois dele, criou a revista Argumento, na qual publicou primeiramente, em 1973, a versão em português de "Literatura e subdesenvolvimento", e começou a escrever uma série de textos envolvendo problemáticas sobre o continente: "El papel de Brasil en la nueva narrativa", em 1979, (publicado posteriormente como “A nova narrativa”), "Os brasileiros e a nossa América”, em 1989, "Literatura, espelho da América?”, em 1995. Conforme explica Gonzalo Aguilar, pesquisador que se ocupou da confluência e do diálogo intelectual entre os críticos brasileiro e uruguaio,

Até esse momento [1970] eram escassas ou inexistentes as intervenções específicas de Candido sobre a literatura hispano-americana, e a identidade do Brasil em sua exterioridade era pensada basicamente em sua vinculação com a França e outros países europeus, por cujas literaturas mostrava uma maior inclinação. Neste ponto, Antonio Candido continuava a tendência cultural brasileira, que remonta ao século XVIII, de formar corpus com as literaturas metropolitanas e apresentar a diferença nacional em relação a estas. "Literatura e subdesenvolvimento" representa uma mudança de perspectiva que põe o Brasil em outra constelação e que permite conceber esse tempo (o da sua identidade como região) sem a instância legitimadora e, ao mesmo tempo, intimidante das literaturas centrais. (Aguilar, 2005, p.109, tradução nossa)

Para Pablo Rocca (2013), o enfoque da proposta de Formação da literatura brasileira - segundo ele, o funcionamento de uma literatura como síntese de tendências particularistas e universalistas -, ao enfatizar o compromisso com o elemento nacional, impediu Antonio Candido de alcançar, inicialmente, uma visão articulada entre a 
literatura brasileira e a dos vizinhos hispano-americanos. Com efeito, é pelo estímulo de Ángel Rama, para que escrevesse "Literatura e subdesenvolvimento", que o crítico começa a incursionar por outras literaturas do continente e a pensar a condição de subdesenvolvimento que compartilham.

Por outro lado, Rama também se viu impulsionado por formulações de Antonio Candido, que favoreceram o desenvolvimento de seus trabalhos sobre a literatura na América Latina. Sobre isso, Ligia Chiappini (2013), em artigo em que destaca os empréstimos e adaptações de conceitos-chaves entre os críticos, lembra que Rama incorpora aos seus estudos a noção de "literatura como sistema", desenvolvida por Candido em Formação da literatura brasileira e também trabalhada em Literatura e sociedade. Ao expandir essa noção à América Latina como um todo, o crítico uruguaio conclui que o sistema estaria ainda incompleto no caso da literatura de países da América Latina, o que revelaria um estágio aquém do já alcançado pela literatura brasileira. Sobre essa influência de sua formulação sobre os estudos de Ángel Rama, declarou Antonio Candido (2002, p.115):

Uma grande satisfação que eu tenho, um dos meus grandes orgulhos na vida, é que o maior crítico literário latino-americano, um uruguaio, Ángel Rama, que era meu grande amigo [...], adotou o meu ponto de vista e passou a aplicá-lo sistematicamente ao estudo da literatura latino-americana, dizendo que isso faz entender a Literatura. Isso para mim é uma compensação muito grande, compensa todos os sequestros de que sou acusado.

O encontro desses dois sistemas de pensamento foi produtivo, portanto, para o trabalho de ambos os intelectuais, mas principalmente para um novo direcionamento dos estudos latino-americanos, que começaram a incluir o único país de língua portuguesa do continente em suas reflexões.

No ensaio "Literatura e subdesenvolvimento", texto em que Antonio Candido concretiza o desafio proposto por Ángel Rama, o crítico brasileiro mantém a perspectiva desenvolvida em Formação 
da literatura brasileira, ao reafirmar a condição de dependência cultural do Brasil enquanto país colonizado. Segundo Candido (1989, p.148), "este é um fato por assim dizer natural, dada a nossa situação de povos colonizados que, ou descendem do colonizador, ou sofreram a imposição de sua civilização". O crítico argumenta que as literaturas de países colonizados como o Brasil são "galhos" das metropolitanas, sendo delas dependentes por um "vínculo placentário" que as uniu. Haveria, portanto, uma "influência inevitável”, uma "inevitável dependência” em relação a elas, o que tornaria ilusória a ideia de supressão de contatos ou influências. Quando se atenua a importância dos principais países colonizadores da América Latina, Portugal e Espanha, o que ocorre é apenas uma "autonomia reflexa”, uma vez que se verifica a transferência da dependência a outros países europeus, como foi com a França no século XIX. ${ }^{7}$

A superação dessa dependência se revelaria pela capacidade de produzir obras de qualidade, influenciadas não por modelos estrangeiros imediatos, mas por exemplos nacionais anteriores, movimento de retorno à tradição que tornaria mais fecundos, inclusive, os empréstimos de outras culturas. Com o processo de tomada de consciência da condição de subdesenvolvimento pelos países latino-americanos, a imitação passa a ser, cada vez mais, "assimilação recíproca”, não havendo reprodução mecânica, mas participação nos recursos que, tomados como "bem comum" pelo estado de dependência, caminham para a interdependência:

7 Alberto Moreiras (2001), a partir da perspectiva dos Estudos Culturais, mais especificamente dos estudos subalternos, questiona o fato de Antonio Candido considerar "natural" a condição de dependência cultural do continente latino-americano. Para Moreiras, isso significaria uma postura de reafirmação de um ponto de vista imperialista sobre a cultura. Por outro lado, parece defensável o ponto de vista de Candido, no sentido de que o reconhecimento da condição de dominação e subdesenvolvimento é determinante para que se possa enfrentá-la no plano artístico. Conforme argumenta Rebeca Errazúriz Cruz (2013, p.116), analisando essa questão na crítica de Antonio Candido: "A literatura latino-americana só pode tornar-se independente no momento em que se reconhece em sua origem dependente [...]". 
A partir dos movimentos estéticos do decênio de 1920; da intensa consciência estético-social dos anos 1930-1940; da crise de desenvolvimento econômico e do experimentalismo técnico dos anos recentes [1970], começamos a sentir que a dependência se encaminha para uma interdependência cultural [...]. (Candido, 1989, p.153-4)

Nesse contexto, Antonio Candido propõe a existência de diferentes estágios da tomada de consciência da condição de subdesenvolvimento, vinculando-os a diferentes momentos da literatura regionalista, como se esta, dada sua generalidade e persistência, pudesse ser vista como um "termômetro" dessas mudanças de orientação sobre a percepção do atraso do país. Generalidade e persistência, pois o crítico (Candido, 1989, p.157) explica que utiliza o termo "regionalismo" como "toda ficção vinculada a descrições das regiões e dos costumes rurais desde o Romantismo", compreensão do conceito que aqui também se adota. Assim, seriam três os estágios de consciência da condição de subdesenvolvimento da nação brasileira, modelo que seria válido também para o restante da América Latina: no primeiro, predominaria a noção de "país novo", quando o país, sem realizações concretas, mas de modo otimista, atribuía a si grandes possibilidades de progresso futuro; essa fase daria depois lugar à "pré-consciência do subdesenvolvimento", quando superou-se o otimismo patriótico e se passou a observar a degradação do homem como consequência da espoliação econômica; e, por fim, a última fase equivaleria a uma "consciência catastrófica do atraso", ou seja, a plena consciência da condição de subdesenvolvimento. Na literatura do continente, o primeiro momento equivaleria ao período do regionalismo de exaltação nativista; o segundo se iniciaria com a ficção do decênio de 1930, configurando-se como um "regionalismo problemático", pelos chamados "romance social", "romance do nordeste"; e o terceiro, momento auge da consciência do subdesenvolvimento, se firmaria após a Segunda Guerra Mundial, na fase denominada pelo crítico de "super-regionalismo", que estaria representada pela produção 
literária de autores como Guimarães Rosa, Gabriel García Márquez e Juan Rulfo - junto dos quais se propõe aqui pensar o romance de José Cândido de Carvalho.

Diante dessa esquematização, Antonio Candido demonstra compreender o subdesenvolvimento não apenas como uma instância econômica, mas como um dado cultural. A ficção regionalista seria agora, portanto, "consequência da atuação que as condições econômicas e sociais exercem sobre a escolha dos temas" (Candido, 1989, p.156). As áreas de subdesenvolvimento e os problemas do atraso repercutiriam na sensibilidade do escritor como assuntos inevitáveis, podendo significar estímulos tanto positivos quanto negativos para a criação literária. Dessa forma, em países subdesenvolvidos ou com regiões essenciais subdesenvolvidas, o regionalismo emergiria como manifestação válida, por produzir obras de qualidade, motivo de sua relevância na literatura da América Latina:

O regionalismo foi uma etapa necessária, que fez a literatura, sobretudo o romance e o conto, focalizar a realidade local. Algumas vezes foi oportunidade de boa expressão literária, embora na maioria os seus produtos tenham envelhecido. Mas, de um certo ângulo, talvez não se possa dizer que acabou; muitos dos que hoje o atacam, no fundo o praticam. A realidade econômica do subdesenvolvimento mantém a dimensão regional como objeto vivo, a despeito da dimensão urbana ser cada vez mais atuante. Basta lembrar que alguns dentre os melhores encontram nela substância para livros universalmente significativos, como José Maria Arguedas, Gabriel García Márquez, Augusto Roa Bastos, João Guimarães Rosa. Apenas nos países de absoluto predomínio da cultura das grandes cidades, como a Argentina e o Uruguai, a literatura regional se tornou um total anacronismo.

Por isso é preciso redefinir criticamente o problema, verificando que ele não se esgota pelo fato de, hoje, ninguém mais considerar o regionalismo como forma privilegiada de expressão literária nacional; inclusive porque, como ficou dito, pode ser especialmente alienante. Mas convém pensar nas suas transformações, lembrando 
que sob nomes e conceitos diversos prolonga-se a mesma realidade básica. (Candido, 1989, p.158)

Ángel Rama foi o crítico que buscou atender à sugestão de Antonio Candido de redefinir o problema do regionalismo, de modo que as noções de super-regionalismo e transculturação narrativa dialogam na produção dos estudiosos. Sobre essa convergência de conceitos que carregam uma discussão sobre a literatura regionalista na América Latina, explicou o crítico uruguaio, em carta de 1973, ao amigo brasileiro:

[...] Me produce un cierto asombro comprobar como caminamos por sendas paralelas, que creo que se deben a perspectivas críticas similares. Enteramente de acuerdo con la tesis que te conduce progresivamente del cambio hacia el 30 del país nuevo al país subdesarrollado y a una valoración que rescata el regionalismo en una nueva perspectiva que tú llamas superregionalismo.

Eso mismo es lo que bajo el título de "Los transculturadores de la narrativa" te proponía como uno de los temas del seminario en mi visita a Sao Paulo, de tal modo que es tu artículo el que puede servir de base al debate, sin que yo agregue demasiado. (Rama, 2013, p.22)

Apesar da modéstia de Ángel Rama, Antonio Candido, na entrevista já mencionada, admite que o uruguaio "deu uma formulação mais completa e elucidativa" ao problema que ele designara como super-regionalismo:

É a sua teoria [de Rama] da fusão dos dois modos, contribuição de grande originalidade e, a meu ver, a mais perfeita formulação sobre o assunto. No ensaio intitulado "O olhar crítico de Ángel Rama" termino sugerindo como ele foi além do meu ponto de vista: "Isso (a fusão dos 'dois modos') foi sem dúvida uma criação própria do nosso universo literário, e ao defini-lo tão lucidamente Rama deu formulação madura e superior a pontos de vista que tinham sido percebidos por outros (no caso, eu) de maneira parcial e incompleta, e nunca tinham sido 
expostos com originalidade, força integradora e capacidade explicativa tão fortes". (Candido, 2009, p.24-5, grifos do autor) ${ }^{8}$

Diante dessa legitimação da confluência de conceitos pelos próprios autores, será desenvolvida, a seguir, uma leitura das proposições de ambos os críticos, que discutem as relações entre a literatura regionalista e o subdesenvolvimento, à luz do romance $O$ coronel $e$ o lobisomem. Com isso, pretende-se realizar um duplo movimento: tanto verificar como as noções de super-regionalismo, de Antonio Candido, e de transculturação narrativa, de Ángel Rama, se complementam e podem aclarar os sentidos do romance, quanto avaliar, em sentido inverso, como a análise do texto ficcional, por sua vez, pode ressignificar e atualizar as formulações do discurso crítico.

\section{Super-regionalismo e transculturação narrativa: a convergência de conceitos}

Muita coisa importante falta nome.

(Rosa, 1988, p.88)

O super-regionalismo, de Antonio Candido, e a transculturação narrativa, de Ángel Rama, são formulações críticas que auxiliam a compreender a mudança de orientação entrevista nas diferentes modalidades de representação dos romances de José Cândido de Carvalho - transição anunciada quando as obras foram aqui comparadas. Conquanto se perceba, em especial no primeiro conceito, resquícios da necessidade de ressaltar a "universalidade" das obras latino-americanas, é preciso ponderar que essa postura foi necessária àquele momento histórico da crítica, quando se tentava afirmar e consolidar, também no plano intelectual, a autonomia e a qualidade

8 Por "fusão dos dois modos", Antonio Candido refere-se à junção, percebida por Rama e comentada a seguir, de técnicas de vanguarda com elementos do universo regional. 
das literaturas do continente. Desse modo, guardada a devida cautela em relação à distância que é, por vezes, marcada entre o regional e o pretenso "universal", convém explorar as proposições de ambos os críticos e observar como podem cooperar para a análise do romance O coronel e o lobisomem.

São poucas as linhas de "Literatura e subdesenvolvimento" que Antonio Candido (1989) dedica à definição do "super-regionalismo", fato que, se por um lado, deixa a ideia um tanto lacunar, por outro, a torna sugestiva e fecunda pelo alcance de significações. Correspondendo a uma terceira fase do processo de tomada de consciência da condição de subdesenvolvimento, Antonio Candido (1989, p.160) classifica a prosa desse período como uma "florada novelística marcada pelo refinamento técnico", em que os traços antes pitorescos adquirem "universalidade". Embora insista na ideia de universalidade, instigante em sua definição são os demais elementos que destaca como característicos dessa etapa: conforme explica, trata-se de uma prosa "nutrida de elementos não realistas, como o absurdo, a magia das situações” (Candido, 1989, p.160, grifos nossos). E a explicação para a designação "super-regionalismo" não é menos reveladora do que se constatou até o momento: além de evocar o regional, fora criada, segundo Candido (1989, p.160), pensando-se em "surrealismo" ou "super-realismo", o que confirma uma estética afastada da representação realista convencional.

Para completar, o crítico afirma que essa fase, "que carrega uma dose importante de ingredientes regionais", corresponde "à consciência dilacerada do subdesenvolvimento e opera uma explosão do tipo de naturalismo que se baseia na referência a uma visão empírica do mundo; naturalismo que foi a tendência estética peculiar a uma época em que triunfava a mentalidade burguesa e correspondia à consolidação das nossas literaturas" (Candido, 1989, p.161, grifos nossos). Essa argumentação vai ao encontro das constatações de tantos ficcionistas e críticos aqui arrolados, sobre a existência de uma nova etapa do regionalismo (seja por essa ou outra denominação) em meados da década de 1950. Muitos deles notaram, inclusive, o papel crucial do insólito (em sentido amplo) para tal diferenciação no romance 
de José Cândido de Carvalho, como Zilberman, Dacanal, Bernd, além de Bernardo Élis, Érico Veríssimo, entre outros. Em vista da formulação genérica de Antonio Candido, endossada indiretamente por tantos nomes, corrobora-se, portanto, que o movimento visualizado no interior da produção de José Cândido - ao transitar de um romance com padrão de representação mimético-realista, para outro, de caráter "fantástico" - encontra correspondência com uma transformação estética da literatura regionalista brasileira da segunda metade do século XX.

Ainda nesse sentido, é interessante notar que Antonio Candido inscreve nessa nova etapa explicitamente apenas Guimarães Rosa entre os escritores brasileiros, colocando-o ao lado de outros autores latino-americanos, como Gabriel García Márquez e Juan Rulfo, que também se ocuparam do universo regional afastando-se da estética realista de representação. Mas, para constituir-se enquanto "fase", tal como Candido (1978, p.160) compreende o super-regionalismo, sua teoria parece permitir, e mesmo ensejar, a inclusão de outros ficcionistas da literatura brasileira para a composição de um rol de autores. Afinal, a ideia de fase pressupõe por si mesma um número mínimo de escritores contemporâneos, e acredita-se que, pelos próprios indícios deixados na definição de Candido, não apenas Rosa possa ser visto, isoladamente, em diálogo com os autores. Outras conexões são possíveis, tal como o demonstrou Zilá Bernd (1998), ao identificar e analisar os pontos de convergência do "maravilhoso" entre a prosa de José Cândido de Carvalho e a literatura caribenha. Dessa forma, constatar a existência de outros escritores brasileiros da época, compartilhando de traços dessa tendência denominada por Candido super-regionalista tem por efeito ampliar o âmbito de atuação de sua proposta, além de, o mais importante, favorecer a compreensão do lugar de romances como $O$ coronel e o lobisomem, que até então ficaram à margem dos esforços de definição do período.

Antes mesmo de cunhar o termo super-regionalismo e sistematizá-lo na escala que leva em conta o grau de consciência do subdesenvolvimento, Antonio Candido já havia apontado vários aspectos que definiriam essa categoria, quando analisou, em um ensaio de 1957, 
o romance Grande sertão: veredas. Nessa ocasião, Candido (1978, p.123) já reconhecia, no romance rosiano, um universo extraordinário - semelhante em muitos aspectos ao universo mágico do romance de José Cândido -, com "leis próprias", cuja compreensão dependeria de aceitar "certos ângulos que escapam aos hábitos realistas", até então, dominantes na ficção brasileira.

A preocupação com essa dimensão insólita do romance percorre todo o ensaio, de modo que o crítico observa ainda: a "coexistência do real e do fantástico, amalgamados na invenção e, as mais das vezes, dificilmente separáveis" (Candido, 1978, p.125); a existência de um "homem fantástico a recobrir ou entremear o sertanejo real"; a ação lendária articulada ao "espaço mágico"; e um sistema de "jagunçagem que remonta à lenda” (1978, p.129). Explicando o que chamou de "princípio de reversibilidade", Candido (1978, p.135) aponta a importância da ambiguidade e da fusão de contrários na obra (real e irreal, aparente e oculto, dado e suposto), que se exprimem por um estilo também ambíguo, "popular e erudito, arcaico e moderno, claro e obscuro, artificial e espontâneo". Ao leitor, caberia esquecer "os pendores realistas" para penetrar na atmosfera em que "o mágico e o lógico, o lendário e o real" se combinam (Candido, 1978, p.135). A figura do demônio no romance rosiano - também presente em $O$ coronel e o lobisomem - comporia esse cenário, pois "nada encarnaria melhor as tensões da alma, nesse mundo fantástico, nem explicaria mais logicamente certos mistérios inexplicáveis do Sertão" (Candido, 1978, p.136). Trata-se, em síntese, do "Sertão, fantástico e real" (Candido, 1978, p.132). Desse modo, essa perspectiva analítica, segundo a qual "o real é ininteligível sem o fantástico, e que ao mesmo tempo este é o caminho para o real" (Candido, 1978, p.139), pode ser entendida como uma antecipação de sua formulação sobre o super-regionalismo.

O tema reaparece em 1972, no ensaio "A literatura e a formação do homem". Nesse texto, Candido reitera a tendência de superioridade estética de obras de temário urbano na literatura brasileira, mas o faz para resgatar a vitalidade e a importância do regionalismo: 
[...] hoje, tanto na crítica brasileira quanto na latino-americana, a palavra de ordem é "morte ao Regionalismo", quanto ao presente, e menosprezo pelo que foi, quanto ao passado. Esta atitude é criticamente boa se a tomarmos como um "basta!" à tirania do pitoresco, que vem a ser afinal de contas uma literatura de exportação e exotismo fácil. Mas é forçoso convir que, justamente porque a literatura desempenha funções na vida e na sociedade, não depende apenas da opinião crítica que o Regionalismo exista ou deixe de existir. Ele existiu, existe e existirá enquanto houver condições como as do subdesenvolvimento, que forçam o escritor a focalizar como tema as culturas rústicas mais ou menos à margem da cultura urbana. O que acontece é que ele se vai modificando e adaptando, superando as formas mais grosseiras até dar a impressão de que se dissolveu na generalidade dos temas universais, como é normal em toda obra bem-feita. E pode mesmo chegar à etapa onde os temas rurais são tratados com um requinte que em geral só é dispensado aos temas urbanos, como é o caso de Guimarães Rosa, a cujo propósito seria cabível falar num super-regionalismo. Mas ainda aí estamos diante de uma variedade da malsinada corrente. (Candido, 2002, p.86-7, grifos nossos)

A discussão sobre o regionalismo, a "malsinada corrente" ou, ainda, a "tendência tão perigosa quanto inevitável" (Candido, 1989, p.206), é retomada, entre outros textos, em 1999, no ensaio "Literatura, espelho da América?”. Nessa publicação, Candido (1999) volta a percorrer os estágios da literatura regionalista brasileira desde o Romantismo até a prosa de Guimarães Rosa. Conforme afirma, o período anterior a Rosa, cujo paradigma foi a produção de Graciliano Ramos, já havia se desprendido da classificação de "romance regionalista" para dar lugar à ideia de "romance social", dado o enfoque político das obras. Porém, quando o regionalismo era considerado algo superado pela crítica, surge "a maior obra de cunho regional da narrativa brasileira, a de Guimarães Rosa" (Candido, 1999, p.110). Por essas ponderações, percebe-se que Antonio Candido "reconcilia-se" com o regionalismo, antes aceitando-o como faceta importante da obra, que tentando dela subtrair sua 
dimensão regional. Nesse sentido, Candido (1999, p.112) amplia sua formulação sobre o super-regionalismo, favorecendo-a por uma nova percepção do fenômeno:

[A prosa de Guimarães Rosa] Era algo de fato novo e mesmo inovador, mas dentro do temário regional. Guimarães Rosa elaborou as novelas de Corpo de baile e o romance Grande sertão: veredas com um sentimento de homem que supera, mas conserva, o particularismo do pitoresco. Por isso, a sua obra dava a ideia de uma narrativa de cunho regional que no entanto exprimia o que o homem tem de mais universal. Ela pertence a um certo tipo de literatura latino-americana contemporânea que constitui verdadeiro feito cultural e foi muito bem caracterizada por Ángel Rama: a fusão difícil e paradoxal das técnicas de vanguarda (que são cosmopolitas e olham para o futuro) com o mundo regional (que é local e tradicionalista, olhando para o passado).

Assim, o que antes parecia certo repúdio e menosprezo ao regionalismo surge agora sob melhor definição, buscada no trabalho crítico de Ángel Rama, diante da explicação de que houve, nessa fase, uma integração entre as técnicas vanguardistas (cosmopolitas, urbanas, voltadas ao futuro) e o universo regional (tradicional, voltado ao passado). Nesse ensaio, portanto, embora a universalidade persista enquanto horizonte, nota-se a efetivação de um novo direcionamento de sua crítica, mediante o aprofundamento de questões já prenunciadas em "Literatura e subdesenvolvimento" - conforme notou Gonzalo Aguilar (2005) -, sendo elas: a inversão da hierarquia cosmopolitismo/regionalismo, a construção de um relato alternativo ao evolucionismo modernista e a postulação de escritores canônicos do super-regionalismo. Para Marli Fantini (2003, p.46), que endossa a opinião de Candido, Guimarães Rosa fortalece, de fato, um "cânone alternativo" que, por meio de formações literárias híbridas, se constitui por um "duplo gesto de assimilação e resistência frente ao "cânone universal”". Para Candido, essa prosa representada por Guimarães Rosa: 
É uma espécie de superação do nacionalismo romântico, mediante o uso do tema regional como veículo de uma expressão de cunho universalista. O que era modalidade mais típica do particular nacional se torna fórmula do que há de mais geral. De certo modo, o particularismo romântico (regionalismo, no caso) acompanhou as mudanças da literatura e acabou se expandindo no universalismo do discurso moderno (super-regionalismo). (Candido, 1999, p.112)

O crítico brasileiro conclui que em países onde há zonas de atraso econômico e social, subdesenvolvidas, é impossível anular a representação literária desses fatores, uma vez que são realidades significativas que se impõem à consciência do escritor. Haveria, assim, uma relação necessária entre a organização interna da obra (o texto em si) e a sua ancoragem na realidade, o que lhe é exterior e de onde extrai sua matéria:

Nos países da América Latina há uma equação constante entre gratuidade e empenho, bem clara na persistência do regionalismo em sucessivas modalidades, mesmo quando as literaturas que servem de modelo (europeias, norte-americanas) já não o praticam mais em obras de alta qualidade. E essa reflexão leva a confiar na perenidade da literatura, porque ela corresponde a necessidades profundas e é capaz de assimilar a inovação sem perder a capacidade de representar as particularidades do contexto onde funciona. (Candido, 1999, p.113)

Ángel Rama, por sua vez, discutiu também as contradições vigentes no processo de formação histórica, política e cultural da América Latina. No âmbito da literatura, isso correspondeu ao reconhecimento de uma dialética entre os sucessivos estágios de modernização e a concomitante tendência à recuperação do que se considerava então arcaico, local, regional. Esse conflito resultante do contato entre diferentes culturas, com diferentes graus de modernização, ocorreria, segundo o crítico uruguaio, em dois planos geográficos: tanto "entre as metrópoles externas e as cidades 
latino-americanas", como também entre as cidades latino-americanas e "suas regiões internas", sendo que a este encontro dispensa maior atenção (Rama, 2001, p.217). Em outras palavras, Rama está pensando, no primeiro caso, na espinhosa relação entre as culturas latino-americanas (e por extensão, suas literaturas) em relação às europeias, e, no segundo, na tensão cultural que ocorre internamente nos países latino-americanos, entre suas capitais (ou os grandes centros urbanos) e as regiões interioranas rurais. Sobre esses impactos modernizadores, provenientes de questões políticas e econômicas, mas que afetam igualmente a esfera de produção cultural, o crítico afirma:

No variado panorama aculturante atual, testemunho da dinâmica das sociedades latino-americanas contemporâneas, um extenso capítulo é ocupado pelos conflitos das sociedades regionais que se deparam com a modernização incorporada por intermédio de cidades e portos, proclamada transmissora do progresso e que as elites urbanas dominantes instrumentam. [...] Os regionalistas respondem a esse conflito: tentarão evitar a ruptura, que se aproxima, entre os diferentes setores internos que compõem a cultura latino-americana, devido à desigual evolução experimentada e aos diversos ingredientes originários, enquanto assistem a uma aceleração modernizadora. (Rama, 2001, p.212-3, grifos nossos)

Diante desse quadro, a transculturação narrativa, tal como a formula Ángel Rama (2004), surge justamente como uma resposta, no âmbito literário, às tensões provocadas pelos influxos modernizadores no continente latino-americano. ${ }^{9}$ Disso decorreria o com-

9 Ángel Rama (2004, p.32) empresta o termo "transculturação" dos estudos do antropólogo cubano Fernando Ortiz, que em 1940 o propôs como modo de repensar as formas de trocas culturais. Enquanto a aculturação consistiria, basicamente, em adquirir uma outra cultura, a transculturação seria o processo de transitividade de uma cultura a outra, segundo uma visão não hierarquizada de interatividade entre esses universos em confronto. Segundo Roseli Barros Cunha (2007, p.130), essas expressões denominam, na verdade, um mesmo 
plexo e produtivo jogo entre vanguarda e regionalismo na literatura latino-americana, assunto que se tornou o motivo central da obra do crítico uruguaio. Assim, em uma época em que a crítica se voltava às vanguardas, Ángel Rama (2001, p.137) contribuiu significativamente para revalorizar o regionalismo, examinando-o como elemento também fundamental aos processos de criação da literatura do continente:

Na América Latina o regionalismo veio para ficar, e ainda é possível percebê-lo nos jovens narradores. Isso pode ser comprovado se formos capazes de conceber o regionalismo como uma força criadora que se manifesta ao compasso do processo cultural que se constrói incessantemente na região e não como fórmula estética restrita produzida nos anos de 1920 e de 1930 [...].

Com isso, o crítico enfatiza que o regionalismo foi capaz de se adaptar a novas fórmulas estéticas, maleabilidade responsável por garantir sua vitalidade nas letras latino-americanas. Conforme explica Roseli Barros Cunha (2007, p.180), estudiosa da produção do crítico uruguaio, por essa perspectiva, a tradição do regionalismo e a modernização trazida com as vanguardas se inter-relacionariam, não significando, portanto, desconfiança ou rejeição para com algum desses polos constitutivos da narrativa dos transculturadores:

[...] em Transculturación narrativa en América Latina, a vanguarda seria o próprio impacto modernizador ocorrido na sociedade latino-americana. Este não seria visto de forma negativa, pois nele residiria a possibilidade de revitalização da cultura autóctone. Como consequência desse impacto externo - vanguarda - sobre a cultura regional, produzir-se-ia a transculturación.

processo, apesar de o fazerem por diferentes enfoques: na aculturação, o foco é apenas o contato entre culturas; na transculturação, pela qual opta Rama, valoriza-se a possibilidade de respostas por parte da cultura que recebe o impacto modernizador. 
O Brasil, nesse contexto, é destacado por Rama (2004, p.119) como o "laboratório mais fecundo" para o exame de tais conflitos e de suas originais soluções no plano literário. Enquanto nos países vizinhos de língua espanhola a literatura regionalista se viu a ponto de perecer, no Brasil "a narrativa regionalista não se viu igualmente ameaçada mas simplesmente discutida mediante proposições cosmopolitas” (Rama, 2001, p.197), como as de Mário de Andrade, ao questionar o regionalismo. Porém, Rama lembra o vigor que a literatura de cunho regional continuou a ter com escritores como Rachel de Queiroz, Graciliano Ramos e José Lins do Rego. Por isso, em seu ponto de vista, Guimarães Rosa "não vai se pôr a salvar tradições ameaçadas, mas sim superar bases estilísticas que estavam em vias de se esclerosar pela formulação de um modelo único" (Rama, 2001, p.198). Desse modo, em sua opinião, se os temas, personagens, cenários e situações narrativas de Grande sertão: veredas não se afastam muito dos praticados pelo regionalismo, parecem, contudo, deles diferentes em razão da novidade dos recursos técnicos, capazes de traduzir uma cosmovisão renovada a essas categorias. Assim, haveria uma "elevação estética" que não pressuporia nem ruptura, nem anulação, mas "transformação" e abertura. Essa "elevação estética” verificada por Rama (2001, p.200) remete, seguramente, ao "refinamento técnico" de que falara Candido (1989, p.160), ponto que reitera a sintonia de perspectivas entre os críticos quando discutem a atualização expressiva do regionalismo. Ao crítico uruguaio, esse novo momento da prosa regionalista significaria, como também sugeriu Candido, o afastamento do tipo de representação mimético-realista, em favor da incorporação na narrativa do imaginário mítico, fantasioso, dos grupos mais afastados da racionalidade da civilização moderna:

O discurso literário do romance regionalista respondia basicamente às estruturas cognoscitivas da burguesia europeia. [...] Ao se rejeitar o discurso lógico-racional, produz-se novamente o retorno do regionalismo a suas fontes locais, alimentadoras, e inicia-se o exame das formas dessa cultura segundo seus praticantes tradicionais. 
É uma busca de realimentação e de sobrevivência, extraindo da herança cultural as contribuições válidas, permanentes.

Essa retomada reestabelece um contato fecundo com as fontes vivas da invenção mítica, inextinguíveis em todas as sociedades humanas, mas ainda mais alertas nas comunidades rurais. (Rama, 2001, p.277)

Note-se que essa perspectiva crítica abre caminhos para propor um ângulo de visão diferenciado em relação aos estudos do romance de José Cândido anteriormente discutidos. Neste percurso reflexivo, as formulações de Ángel Rama, ampliando as de Antonio Candido, impõem-se como embasamento consistente no sentido de suprir as lacunas do trabalho de José Hildebrando Dacanal, que desconsiderava, por exemplo, os movimentos vanguardistas e também a tradição regionalista brasileira. Essa fundamentação redimensiona, ainda, a discussão que Regina Zilberman elaborou pelo recorte do mito, situando-a como parte de um panorama crítico de maior alcance. Do mesmo modo, a leitura que Zilá Bernd realiza pelo viés do maravilhoso reconfigura-se, ganhando uma nova significação. Essas múltiplas abordagens da obra, seja pelo enfoque do épico, do mítico, do maravilhoso ou do lendário, convergem todas como pontos de vista legitimáveis diante do fenômeno reconhecido e analisado pela parceria crítica de Candido e Rama. Finalmente, diante desse painel que envolve tanto a reflexão acerca da produção intelectual e artística de José Cândido, quanto do universo crítico e historiográfico que procuraram discuti-lo, desenvolvem-se, a seguir, algumas considerações analíticas sobre o romance $O$ coronel e o lobisomem. Mantendo em vista a capacidade da obra de apreender e problematizar a realidade, o intuito deste último movimento é alinhavar alguns resultados já disseminados, colocando-os, por fim, à prova da fatura do texto e desvelando seus mecanismos composicionais. 


\section{O mundo mágico de $O$ coronel e o lobisomem}

Deus meu! No sertão, o que pode uma pessoa fazer de seu tempo livre a não ser contar histórias?

João Guimarães Rosa

O processo de modernização do país aparece nas entrelinhas de toda a produção literária de José Cândido de Carvalho, das crônicas aos romances, revelando-se como uma incessante preocupação intelectual do escritor para com as transformações de seu tempo. No romance $O$ coronel e o lobisomem, esse interesse se manifesta por meio da história de um coronel, representante decadente de uma elite agrária, que já não encontra espaço em um mundo capitalista em fase de desenvolvimento urbano e industrial. O desajuste existencial do protagonista, o coronel Ponciano de Azeredo Furtado, decorre de sua incapacidade de se adaptar às mudanças que se imprimem não apenas nos espaços em que transita, mas em toda a dinâmica política, econômica, social e cultural de sua época. Com o avanço tecnológico, mudam-se os meios de produção, as estruturas sociais, as relações de poder, e Ponciano permanece à margem desse progresso. Uma vez que o impacto da modernização se lhe impõe como uma realidade da qual não consegue escapar - a não ser pelas brechas da imaginação e da fantasia -, o romance afirma-se como uma resposta crítica e pessimista, no plano artístico, às contradições de um momento histórico de euforia desenvolvimentista.

No âmbito da América Latina, os efeitos da modernização também foram uma preocupação intelectual de Ángel Rama, que procurou analisar como as literaturas do continente a eles reagiram. Por essa razão, os estudos do crítico uruguaio fornecem bases para se pensar a criação ficcional de José Cândido. Nesse sentido, Rama (2004) reconhece dois principais impactos modernizadores por que a América Latina, de um modo geral, teria passado: o primeiro teria ocorrido no final do século XIX, e o segundo, no período entreguerras do século XX. Ambas as ocasiões teriam promovido estímulos decisivos para os rumos tomados pela literatura regionalista do 
continente, significando, portanto, momentos marcados por diferentes soluções estéticas. Essas diferentes soluções distinguiriam os "primeiros regionalistas" - entendidos pelo crítico como autores de obras da década de 1910, o que parece corresponder ao pré-modernismo brasileiro - dos "regionalistas plásticos" ou "transculturadores", cuja prosa é posterior a 1940, e entre os quais se pode situar José Cândido de Carvalho.

Para examinar a prosa destes últimos, Ángel Rama (2004) distingue três níveis em que se concretizaria o processo de transculturação narrativa. $\mathrm{O}$ primeiro deles corresponderia ao plano linguístico da narrativa, o segundo, ao estrutural, e o terceiro, ao da cosmovisão. Considerando a existência de uma relação intrínseca entre os níveis, entende-se que essa decomposição se estabelece apenas com o fim de propiciar uma melhor visualização do fenômeno examinado pelo crítico. De qualquer modo, também por motivo de clareza de exposição, o romance $O$ coronel e o lobisomem será aqui analisado sob esse enfoque organizacional, ao mesmo tempo em que se discute a proposta do crítico.

No plano linguístico, Ángel Rama (2004, p.40) reconhece que houve uma mudança significativa da prosa dos regionalistas da primeira década do século XX para a dos transculturadores de meados do século. Enquanto os primeiros procuravam marcar textualmente a distância entre a variedade linguística do narrador, que atendia ao padrão culto, e a variante do homem rural, o grupo dos transculturadores aboliu essa dicotomia, incorporando à voz do narrador a fala do homem campesino. Segundo Rama (2004, p.42),

La que antes era la lengua de los personajes populares y, dentro del mismo texto, se oponía a la lengua del escritor o del narrador, invierte su posición jerárquica: en vez de ser la excepción y de singularizar al personaje sometido al escudriñamiento del escritor, pasa a ser la voz que narra, abarca así la totalidad del texto y ocupa el puesto del narrador manifestando su visión del mundo. 
Com efeito, o trabalho com a linguagem é, seguramente, um dos pontos de maior destaque do romance $O$ coronel e o lobisomem. Isso não ocorre apenas em vista de ser a literatura a arte da palavra, o que tornaria a afirmação pertinente a qualquer outro texto de ficção. $\mathrm{O}$ caso é que a inovação da linguagem do romance fez que a obra se tornasse, inclusive, objeto de muitos estudos da área linguística. $\mathrm{Na}$ crítica literária, conforme se demonstrou, vários autores pontuaram a forma diferenciada com que José Cândido maneja a linguagem, lembrando a prosa de Guimarães Rosa, mas sendo algo novo mesmo diante dela. Não à toa, o romancista se queixava de sua luta com as palavras e da dificuldade de encontrar a expressão adequada ao universo de cada narrador.

A linguagem de Ponciano é a expressão da sua identidade e do modo como vê o mundo. Dizendo-se "de palavra educada", o narrador logo revela seu temperamento explosivo e os arroubos de que é capaz: “- Seu filho de égua, que pensa que é?" (Carvalho, 1983, p.3). Como se observa, o imaginário do coronel, constituído por referências rurais, invade sua fala pelas escolhas vocabulares, pelas comparações, metáforas e metonímias que utiliza. Homem do campo, educado por padres, quando jovem é obrigado pelo avô a estudar na cidade, mas não chega a se tornar um "doutor formado", já que "de letra", dizia, "nem queria sentir o cheiro" (Carvalho, 1983, p.7). De qualquer modo, vaidoso por sua patente de coronel, crendo-se instruído e sagaz, a linguagem de Ponciano oscila entre o arcaísmo e o refinamento, entre um estilo que se quer empolado e erudito e outro, ao sabor da informalidade oral do sertanejo, junções que conduzem ao cômico. Nota-se, com isso, uma espécie de hibridismo linguístico, expressão de narrativas da transculturação. Transitando conflituosamente entre dois mundos, entre dois universos culturais, o rural e o urbano, o rústico e o civilizado, o arcaico e o moderno, entre os valores do passado e as exigências do presente, as formações discursivas do narrador são contaminadas por essas imbricações de distintas instâncias.

As expressões, o vocabulário, os neologismos, a sintaxe, tudo converge para esse estilo peculiar, que é uma combinação de 
diferentes variantes linguísticas, oriundas de diferentes espacialidades e temporalidades, estilo herdeiro da liberdade do Modernismo e da tradição do regionalismo. Com isso, o autor elabora um narrador que fala de dentro de uma comunidade rural, valendo-se de seu sistema linguístico, mas recriando-o artisticamente. José Cândido, assim como são descritos os transculturadores, foi um escritor que vivenciou a realidade de regiões interioranas, afastadas de áreas de maior desenvolvimento. Desse modo, não se torna necessário a ele tentar "imitar de fora" a fala regional, uma vez que ele a reelabora "de dentro", como invenção estética. A voz popular passa, então, de individualizadora de uma determinada personagem, para se tornar o próprio narrador, de modo que sua linguagem manifesta sua visão de mundo e sua identidade. Essa solução linguística que restaura uma expressão e uma visão regional do mundo, reinventando-a, funciona, portanto, como uma "resposta modernizada" ao impacto modernizador, mostrando-se capaz de revitalizar uma tradição que se pensava superada.

Já no plano da "estructuración literaria" (Rama, 2004, p.43) - ou "composição literária”, conforme tradução (Rama, 2001, p.221) -, o crítico defende que houve maior dificuldade do romance latino-americano em responder ao impacto modernizador externo, pois suas formas tradicionais de narrativa eram muito diferentes das formas modernas estrangeiras. Para explicar essa distância, Rama (2004, p.43) lembra que o romance regional havia se elaborado, inicialmente, sob os modelos narrativos do naturalismo do século XIX, adequando-os às suas necessidades expressivas. O problema seria que, com o surgimento das vanguardas, o leque de recursos estrangeiros passaria a fecundar justamente as narrativas urbanas ou cosmopolitas (nas vertentes que o autor, tendo em vista a literatura de todo o continente, denomina "realista-crítica" e "fantástica"). Como o regionalismo correspondia a uma visão racionalista, descendente da sociologia e da psicologia do século XIX, o crítico vê aí a dificuldade de adaptação da literatura regionalista às estruturas dos romances vanguardistas.

Nos casos bem-sucedidos em que se superou essa dificuldade composicional, Rama reconhece que as respostas foram fornecidas, 
como no plano linguístico, pelo manancial da cultura tradicional, em que se buscaram mecanismos literários próprios, adaptáveis às novas circunstâncias e suficientemente resistentes à erosão modernizadora. Para explicar como exatamente esse retorno às fontes populares se daria em termos de técnica narrativa, o crítico apresenta, primeiramente, apenas dois breves exemplos da prosa de transculturadores. Nesse ponto, sua argumentação mostra-se, porém, um tanto limitada e sem maiores esclarecimentos quando procura opor as técnicas que considera extraídas da tradição daquelas que seriam vanguardistas: o "monólogo discursivo" de Grande sertão: veredas estaria em oposição à técnica vanguardista da fragmentação mediante o fluxo de consciência; e o "contar dispersivo das comadres" com "suas vozes sussurrantes", de Pedro Páramo, contrastaria com a técnica vanguardista do "relato compartimentado", pela justaposição de pedaços aleatórios. O próprio crítico reconhece que essas técnicas utilizadas por Rosa e Rulfo marcariam apenas uma "sutil oposição" aos recursos vanguardistas, mas defende que a origem delas estaria na narração oral e popular, razão de sua diferenciação.

O ponto que parece ser o mais decisivo à transformação formal da prosa dos "primeiros regionalistas" para a dos "regionalistas plásticos" ou "transculturadores" é, no entanto, pouco explorado por Ángel Rama (2004, p.45): embora o crítico proponha que Cem anos de solidão seja, "talvez", o melhor exemplo de resposta transculturadora no plano da composição narrativa, acaba por não desenvolver as potencialidades dessa sugestão. Rama (2004, p.45) afirma que Gabriel García Márquez resolveu estilisticamente, nesse romance, a difícil conjunção entre o "plano verossímil e histórico dos acontecimentos e o maravilhoso, em que se situaria a perspectiva das personagens sobre tais eventos reais". Diante do caminho percorrido até aqui, com auxílio da trilha já aberta pela crítica de José Cândido e, observada também, tangencialmente, na de Guimarães Rosa, pode-se supor que esteja nesse jogo entre o real e o insólito, entre o verossímil e o maravilhoso, o denominador comum dos romances ditos "transculturadores" ou "super-regionalistas". Essa perspectiva não contraria a de Ángel Rama; antes, a assegura, 
pois continua a sustentar a procedência oral e popular da narração. Como já havia apontado Antonio Candido (1989, p.160-1), essa fase da literatura apresenta "uma dose importante de ingredientes regionais" e "elementos não realistas, como o absurdo, a magia das situações”. Trata-se, portanto, da busca de mecanismos literários próprios como resposta aos recursos vanguardistas. Essas soluções estariam na recuperação de estruturas literárias associadas às formas mais próximas da oralidade, cultivadas por tradições não afalbetizadas. Em entrevista a Beatriz Sarlo, Rama (1980, p.14) comenta que o fenômeno vai além da adaptação passiva das formas estrangeiras associada a conteúdos nacionais:

[...] generar una transformación técnica trabajando no sólo en la aplicación de los instrumentos internacionales, sino de formas que derivan de las posibilidades internas de su materia literaria. Y, en los casos mencionados, ello significó sallirse de la literatura. Por eso finalmente, vuelvo a insistir en que debe variarse el concepto de literatura con la incorporación de una cantidade de materiales no literários (del cuento oral al documento histórico). Parece ésta la única posibilidade de renovación y, al mismo tiempo, de construcción de un nuevo sistema técnico para nuestra literatura.

No romance $O$ coronel e o lobisomem, como muitos de seus críticos notaram, há um desvio considerável dos padrões da narrativa realista tradicional, que haviam sido determinantes à prosa regionalista brasileira dos anos 1930 (ou o chamado "romance de 30"). Em lugar de uma narrativa de todo realista, mimética, voltada à verossimilhança, reconhece-se um tipo de representação que se inclina ao sobrenatural, ao extraordinário, ao insólito. Não se trata, no entanto, de uma ruptura total com a representação realista, de modo que não se está no terreno da fantasia plena. O romance apresenta, antes, na linha do que afirmou Rama (2004, p.45), uma "conjunção entre o plano verossímil e histórico dos acontecimentos e o maravilhoso, em que se situa a perspectiva das personagens sobre esses eventos reais". 
Conforme já ficou dito, o final da narrativa torna incontestável a dimensão sobrenatural do romance, pois é quando se percebe que se esteve diante de um narrador morto, porém inconsciente dessa sua condição, e que ainda irá lutar contra o diabo. A atmosfera insólita do romance não se limita, contudo, a esse aspecto macro da narrativa. Por todo o texto estão disseminados elementos procedentes do folclore, das lendas, do imaginário popular, das crendices e superstições ligadas ao meio rural. Povoam esse universo mágico fantasmas de antepassados, lobisomens, sereias, ururaus e boitatás (sendo esses últimos, espécies de, respectivamente, lagarto e cobra que soltam fogo). Além disso, animais comuns também ganham contornos irreais, pelo exagero de suas dimensões, força ou valentia, como são os casos das onças e cobras que rondam as propriedades de Ponciano e do valente galo de rinha que chega a ser congratulado com a patente de "capitãozinho".

Essa é a atmosfera predominante nos oito primeiros capítulos da obra, parte que termina com a luta entre Ponciano e o lobisomem. Da apresentação de Ponciano até o oitavo capítulo, do ponto de vista composicional, a narrativa de caráter biográfico (são os "deixados de Ponciano”) segue um padrão episódico, senão de todo aleatório em seu encadeamento, pelo menos sem um fio central que conduza rigidamente a sequência dos fatos. Os acontecimentos, organizados inicialmente segundo uma ordem cronológica relacionada ao crescimento de Ponciano da infância à fase adulta, passam depois a articular-se, mantendo certa autonomia entre si. Assim, pelo filtro da subjetividade do narrador, suas aventuras são harmonicamente dispostas, mas sem a necessidade de uma sequenciação rígida. Por essa relativa autonomia das histórias fantasiosas, verifica-se a fixação das estruturas dos "causos" e lendas no discurso de Ponciano, de modo que essas formas provenientes da narrativa oral e popular plasmam-se na narrativa romanesca.

Já a partir do nono capítulo, quando Ponciano passa a morar na cidade, a narrativa abandona a fabulação para se aproximar dos padrões do romance realista convencional. Isto ocorre porque, embora Ponciano tente resgatar suas histórias do sertão no meio urbano, ali 
elas perdem o sentido, não causando impacto nos ouvintes, pessoas que não acreditam nas façanhas do coronel. Há, portanto, um conflito cultural no romance, refletido em sua espacialidade e temporalidade, que isola Ponciano no meio urbano e tira-lhe a capacidade de nele interagir. Ao final, depois de se deparar com situações que expunham sua vulnerabilidade e incapacidade de se integrar aos códigos de valores e comportamentos do meio urbano, Ponciano retorna, involuntariamente, ao plano do insólito. Com a morte do coronel, o extraordinário se reestabelece de forma contundente e independente da deliberação consciente do narrador ao manejá-lo. Ao final, o sobrenatural adquire duplo sentido: enquanto faz Ponciano se crer poderoso novamente e capaz de enfrentar o demônio, denuncia ao leitor a ilusão do protagonista e sua derrocada diante da morte. Desse modo, é sobretudo pela solução encontrada para o desfecho da narrativa que o romance se inscreve, inegavelmente, no plano do sobrenatural.

Mas, e quanto aos outros eventos insólitos disseminados na primeira parte da narrativa? Seriam eles confirmações da existência dessa dimensão sobrenatural no romance? Para responder a essa pergunta, importa lembrar que o coronel cumpre um duplo papel na narrativa: é ele o protagonista das ações, mas é também ele o narrador, responsável pela exposição de sua história. Uma vez que a apresentação dos episódios extraordinários se dá por intermédio de um narrador-protagonista "invencioneiro e linguarudo" (Carvalho, 1983,p.3), que remete à figura do contador de histórias, a veracidade do narrado é posta em questão. Assim, para analisar o modo como o insólito se estabelece em alguns episódios exemplares da obra, é preciso primeiro discutir alguns aspectos da composição desse narrador pouco confiável, que dá vazão a tal conteúdo. A fim de compreender o aprimoramento do manejo do foco narrativo na prosa de José Cândido, é momento de estabelecer o contraponto prometido entre o romance em questão e a crônica "O Major", de $1958 .{ }^{10}$ Sendo ambas

10 Complementando as informações apresentadas no primeiro capítulo, quando se procurou reconstruir o percurso de criação do romance de 1964, convém 
as narrativas protagonizadas pela figura de Ponciano, a diferença que apresentam no tratamento do foco narrativo é reveladora dos efeitos alcançados pelo insólito na composição romance, conforme se verá na breve digressão a seguir.

A crônica, afastando-se da criação de um espaço autobiográfico do escritor como é típico do gênero, apropria-se da ficcionalidade e da narratividade para tratar da figuração do então "major" Ponciano de Azeredo Furtado. Assim, seu enredo consiste basicamente na apresentação dessa figura por um narrador que rememora e interpreta características e fatos da vida do major. Desse modo, há um narrador em primeira pessoa, que se ocupa em contar uma história da qual é apenas observador, exercendo, portanto, poder absoluto sobre a imagem da personagem descrita. Assim inicia-se o texto:

Qual que! Contador de história foi mesmo velho Ponciano de Azeredo Furtado, o maior patriota exaltado que já se viu em terras e águas de Campos dos Goitacases. Era a própria guerra do Paraguai em pessoa. Só muitos anos depois, lendo o Rocha Pombo e os jornais de domingo, é que me dei conta de que não foi o Major Ponciano o vencedor de Solano Lopes. Que pena! Mesmo assim, o velho ficou sempre de varanda na minha saudade. (Jornal do Brasil, Rio de Janeiro, 16 ago. $1958,1^{\circ}$ Caderno, p.3)

A partir desse trecho inicial, é possível reconhecer algumas informações acerca do narrador e de sua localização espaçotemporal. Campos dos Goytacazes é a cidade natal do cronista José Cândido, mas o tempo em que o narrador da crônica teria vivido é anterior ao

esclarecer que a crônica "O Major" insere-se em um conjunto de publicações esporádicas de José Cândido de Carvalho no Jornal do Brasil. Foram localizados textos assinados pelo autor entre julho de 1957 e maio de 1959, sendo que a maior parte deles se concentra no ano intermediário deste período, em 1958. Essas crônicas costumavam sair na terceira página do primeiro caderno do jornal, espaço em que se discutiam política e literatura. Junto aos textos de José Cândido, ocupando a mesma página do jornal, eram publicadas produções de outros renomados colaboradores do periódico, como Josué Montello, Tristão de Athayde, Manuel Bandeira, Ferreira Gullar e Fernando Sabino. 
da existência do escritor. Isso porque, ao final da crônica, explica-se que Ponciano morrera em 1914, ano de nascimento de José Cândido, logo, se o narrador conhecera o major e inclusive dele sentia "saudades", não se pode afirmar que a voz narrativa corresponda a uma vivência do autor empírico do texto, a menos que haja um deslocamento temporal na ficcionalização da experiência. De qualquer modo, deve-se frisar que, na crônica, a personagem de Ponciano aparece sob uma focalização externa, ao ter sua vida descrita pelo olhar de um outro que resgata sua história. Por meio dessa focalização, o narrador da crônica apresenta o major como um "contador de história”, desabonando a veracidade de seus feitos. Ponciano figura na crônica como alguém que se vangloria por façanhas inexistentes, como o caso citado sobre sua atuação na Guerra do Paraguai, além do que aparece na sequência da narrativa, sobre sua pretensa valentia ao intimidar lobisomens:

- Onde anda esse lobisomem?

É claro que a assombração não aparecia. E Ponciano, no outro dia, nos cafés, armava seu teatro:

- Pois foi o Major chegar e o lobisomem aparecer. Vinha de olho em brasa. Foi quando peguei o bicho pelos chifres e gritei: "Estais em poder do Major Ponciano de Azeredo Furtado e de minhas mãos não saireis". (Jornal do Brasil, Rio de Janeiro, 16 ago. 1958, $1^{\circ}$ Caderno, p.3, grifos nossos)

Nas considerações do narrador em destaque, torna-se ainda mais evidente a descrença e o descrédito nas histórias contadas pelo major. Caracterizando ainda a figura antropológica do contador de histórias, afirma o narrador: "[O major Ponciano] Cultivava um bigode longo, por baixo do qual, como rio maravilhoso, passavam as melhores aventuras que já ouvi” (Jornal do Brasil, Rio de Janeiro, 16 ago. $1958,1^{\circ}$ Caderno, p.3).

Esse procedimento diferencia-se da técnica utilizada no romance, em que o próprio Ponciano, então como coronel e não mais como major, assume a voz da narrativa e, com a autoridade deste narrar, 
relata sua vivência e seus feitos. Essa modificação da configuração do narrador entre a crônica e o romance é fundamental, uma vez que altera o modo como a figura é apresentada ao leitor, determinando a visão e a "versão" da história do militar protagonista de ambos os enredos. Enquanto a figura de Ponciano é apresentada, na crônica, sob a perspectiva de um narrador que o toma como um contador de histórias, no romance, por sua vez, a personagem é construída sob a perspectiva que ela própria possui de si. Desse modo, seus feitos insólitos aparecem, na versão romanesca, sob a autoridade de sua própria voz narrativa, que os declara verdadeiros, na maioria das vezes. Assim, no início do romance, é o próprio coronel Ponciano quem faz sua apresentação:

A bem dizer, sou Ponciano de Azeredo Furtado, coronel de patente, do que tenho honra e faço alarde. Herdei do meu avô Simeão terras de muitas medidas, gado do mais gordo, pasto do mais fino. Leio no corrente da vista e até uns latins arranhei em tempos verdes da infância, com uns padres-mestres a dez tostões por mês. (Carvalho, 1983, p.3)

Note-se que a narração, embora ocorra em um momento posterior ao dos fatos narrados, está permeada de verbos no presente, criando certa ilusão de simultaneidade ou presentificação do relato. Com isso, o coronel Ponciano narra seus feitos de uma perspectiva que se aproxima mais da visão limitada da personagem ao vivenciar os fatos do que do ponto de vista do narrador de memórias, temporalmente distanciado das ações do enunciado. O efeito disso é que o coronel narrador demonstra desconhecer a situação em que se encontra no momento da enunciação. Por isso, somente ao final da narrativa, o leitor descobre que esteve diante de um narrador morto. Essa circunstância não transparece ao longo do relato, uma vez que Ponciano parece desconhecê-la ou, ao menos, não admiti-la, já que a compreensão desse estado implicaria justamente o reconhecimento de uma derrocada que o tempo todo buscou escamotear em seu discurso. Desse modo, a despeito da linguagem e de alguns episódios do 
romance serem fortemente marcados pelo humor, como a trajetória geral do narrador-protagonista é assinalada pela queda que ele quer negar - uma vez que de coronel e proprietário de terras chega à miséria e à morte -, pode-se reconhecer na figura do Ponciano romanesco uma espécie de herói trágico.

Neste ponto, convém lembrar que Ponciano, no romance, por meio da exacerbação da própria masculinidade, virilidade, força, valentia (identificadas em diversas referências efetuadas no decurso da narrativa, como seu porte físico, a imagem da barba, a voz grave, entre outros) permanece em um constante movimento de autoexaltação. Como o que se observa ao final é um herói decadente, que fora trapaceado por aqueles que julgava serem seus amigos, chantageado pela mulher que amara, e empobrecido, percebe-se o quão frágil era a "veracidade" de seu relato, sempre o colocando sob uma perspectiva positiva e vantajosa. Logo, mesmo quando Ponciano, no romance, assume a voz narrativa e tenta atribuir a si mesmo contornos heroicos e positivos, acaba por revelar suas fraquezas e fragilidades. O leitor encontra-se, portanto, diante do chamado narrador infiel, modalidade de narrador frequente na composição da figura do contador de histórias: o narrador infiel mente deliberadamente ou faz uma falsa ideia de si ou dos fatos que descreve, de modo que sua visão é diferente daquela que se apresenta pelo "autor implícito" do texto (Carvalho, 1981, p.47).

Em outras palavras, a figura de Ponciano, quando criada na crônica sob o olhar de um narrador-personagem que o observa (narrador homodiegético), assume a configuração explícita - declarada pelo narrador - de um contador de histórias. Já na passagem da crônica ao romance, algo semelhante ocorre, entretanto, de modo mais engenhoso: quando essa narração passa a ser em primeira pessoa (narrador autodiegético), ou seja, quando a figura de Ponciano passa a apresentar a si próprio assumindo a voz da narrativa, ainda assim há uma "voz de fundo", do autor implícito, que aparece nos deslizes do discurso de Ponciano e acaba, portanto, evidenciando como o coronel continua a ser um "contador de histórias", tal como o fora o major da crônica. Em síntese, o discurso de Ponciano - que escreve 
seus "deixados" à posteridade como prova de sua valentia, como última saída para não se deixar vencer pelas circunstâncias - acaba também por traí-lo e denunciar a personagem frágil que tenta não ser.

Além disso, o próprio coronel revela, em vários momentos, sua tendência a mentir ou a exagerar os fatos, seja ou não em função de histórias sobrenaturais. Assim, as mentiras e exageros surgem com diversas finalidades, como, por exemplo, para assegurar uma posição de homem sábio e experiente, no caso, em assuntos do campo, perante seus subalternos: “[...] no corpo da discussão inventei uma raça de capim que no conhecimento de ninguém era chegada. Sustentei, em manha de advogado de lei, as prendas da tal forragem. Dei até nome: '- Capim-rabo-de-macaco'. Fiz isso por sabedoria" (Carvalho, 1983, p.18); para competir com outras personagens que tentam chamar atenção por histórias de seres sobrenaturais, como na ocasião em que se falava de um ururau: "Repeli a invenção com invenção maior" (p.99); para competir quando o assunto era "conferência sem-vergonhista": "Rebati o avantajado dele com avantajado igual. Fiz ver, apontando o queixo, que um terço de barba perdi em roçar cangote de donzela militante. - Ou mais, seu compadre, ou mais" (p.111); para convencer o padre a visitar o pervertido Juju Bezerra, seu amigo, em agonia de morte: "Sou de muito inventismo, um danado em fazer render uma parolagem - um fio de cabelo vira corda no meu trançado. [...] Inventei, espichei, pois em missão piedosa não tenho pejo de mentir e avantajar" (p.156); ou para convencer a velha Francisquinha a deixá-lo ir para a cidade: "O pior foi engambelar Francisquinha, que não queria deixar seu menino seguir viagem. Inventei imposição do governo, dever do meu ofício de coronel: - Missão de rotina, coisa de somenos" (p.153).

Alertas da pouca confiabilidade do discurso do coronel Ponciano podem ser encontradas inclusive nas falas de outros personagens, como percebeu seu avô: "Esse menino tem todo o sintoma do povo da política. É invencioneiro e linguarudo" (p.3). Note-se o efeito de humor criado pelo uso da palavra "sintoma", que remete à doença, indicando uma crítica ao "povo da política”. As mentiras de Ponciano surgem também nos momentos em que narra mais de uma vez o 
mesmo acontecimento como, por exemplo, quando depois de ter sido rejeitado por uma pretendente, afirma: "Mas o caso é que eu não dava importância a bicho de saia, tratava tudo na ponta da botina, só sabia machucar o coração das pretendentes” (p.158). O mais grave é que Ponciano parece se convencer dessas e outras mentiras.

Nesses pontos da narrativa, o leitor, apoiado tanto nas revelações deliberadas do coronel quanto nas mentiras que ele deixa escapar, adquire um conhecimento mais abrangente da situação que o próprio narrador, cuja visão dos fatos é limitada e distorcida em função de não admitir as situações desfavoráveis por que passa. Passagem semelhante ocorre quando Vermelhinho, o galo do coronel, está perdendo uma disputa com o de Caetano de Melo. Nessa altura do relato, afirma o narrador: "Reavivei a barba para mostrar segurança, acendi o charuto” (p.133). Ao contrário do modo como o Ponciano romanesco justifica seu comportamento, o leitor compreende que a atitude de acender o charuto e torcer a barba são antes ações advindas de sua preocupação e nervosismo, e não da "segurança" que ele diz querer demonstrar com tais gestos. Exemplar dessa atitude, no entanto, é o modo como Ponciano tenta camuflar sua falta de coragem e justificar aos outros (e também a si mesmo) sua "impossibilidade" de agir nas ocasiões em que é convocado a enfrentar alguma situação de risco. Quase como uma espécie de bordão, mas com muitas variantes, por várias vezes o coronel busca explicar-se por um impedimento de ordem militar, em razão de sua patente: "Não podia eu, sem deslustrar a patente, levar a guerra aos pastos de Badejo dos Santos [...]. - É da pragmática militar, seu João Ramalho. É dos regulamentos da guerra, seu compadre" (p.28). Situações como essa são recorrentes na obra e se revelam altamente irônicas, uma vez que o leitor reconhece a distância entre aquilo que se afirma e o que, de fato, acontece. A ironia, portanto, aparece como um procedimento narrativo articulado à construção dessa modalidade de narrador não confiável.

O narrador infiel de O coronel e o lobisomem, enquanto herói trágico, não consegue, no entanto, despertar antipatia no leitor, uma vez que muitas das mentiras que afloram nas entrelinhas de seu discurso 
revelam não a sagacidade e esperteza que autoproclama possuir, mas sim sua ingenuidade e vulnerabilidade no mundo que o cerca. Daí a simpatia que essa personagem complexa consegue despertar nos leitores, ao querer parecer poderoso, mas revelar-se sensível, em um misto de força e bondade, como bem ilustra o seguinte trecho: "De coração compadecido, mas ainda em berro autoritário, mandei que ficasse de pé [...]” (p.24, grifos nossos).

Do mesmo modo, Ponciano, como major na crônica de 1958, inspira também a empatia do leitor ao proclamar-se poderoso, mas, pela denúncia do narrador, revelar-se frágil. O tom lírico do final da crônica é outra antecipação do que seria desenvolvido no romance de 1964:

Mas regressou [da guerra] melancólico, cheio de rosas murchas na alma. [...] Quando começou a vestir a sua farda velha e empoeirada, eis que uma porta se abre e uma lança de vento penetrou nas costas largas do bravo homem de armas. Vento traiçoeiro. Se viesse de frente, com bravura e honestidade, bem que o Major o mandaria para as profundezas do inferno. Mas, assim, à traição, o comedor de fortalezas não pôde fazer nada. Achou melhor morrer de verdade. E morreu na cama, cheio de sinapismos e beberagens. Partiu para os arsenais de Deus de maneira mansa. Um passarinho que se afundasse em chá de erva-doce... (Jornal do Brasil, Rio de Janeiro, 16 ago. 1958, $1^{\circ}$ Caderno, p.3)

Assim, por essa comparação, nota-se que o protagonista da crônica já antecipava em sua trajetória elementos que seriam depois desenvolvidos no romance. A combinação de humor e tragicidade e a fantasia como resolução do conflito entre aquilo que se aspira ser e o que, de fato, se é já estavam, portanto, anunciados na figura do Ponciano que emergia em 1958. Heróis em desajuste com o mundo que os cercam, major e coronel, contadores de história, precisavam buscar refúgio no reino da imaginação, em que poderiam ser o que desejassem. O modo como isso ocorre, no entanto, é diferente nas narrativas em função do foco narrativo. Nesse sentido, o romance 
ganha em sofisticação quando se vale de um narrador infiel que, ao contar suas histórias mirabolantes, é traído por seu próprio discurso.

Mantendo em perspectiva o raciocínio de Ángel Rama acerca da composição das narrativas da transculturação, reconhece-se que a incorporação da figura do contador de histórias pelo romance significa a recuperação de uma forma popular, oriunda da tradição oral. Mais do que isso, ao revitalizar a figura do contador de histórias pela personagem de Ponciano e, por consequência, a forma do "causo" popular, o romance de José Cândido afirma-se como continuador de uma linhagem da literatura regionalista brasileira, pois, conforme explica Juliana Santini (2007, p.92):

A imagem do contador de histórias é recorrente na prosa literária dos últimos anos do século XIX e princípio do século XX. Autores como Valdomiro Silveira, Hugo de Carvalho Ramos e Coelho Neto encontraram, na imagem do narrador popular, solo fértil para a recuperação e a afirmação de traços sintetizadores de particularidades locais.

Observe-se que o período apontado pela pesquisadora coincide com o momento em que, segundo Ángel Rama (2004), a literatura regionalista latino-americana respondia a um primeiro impacto modernizador. Situando José Cândido de Carvalho nessa tradição, Santini (2007, p.205) estabelece uma aproximação entre Ponciano e o narrador sertanejo Romualdo, de João Simões Lopes Neto, por serem ambos contadores de história de feição cômica. Assim, a imagem do contador de histórias, ao encontrar espaço também na ficção que surge após o entreguerras, atualiza um motivo e uma forma da oralidade já inscrita no imaginário da literatura regionalista brasileira de décadas anteriores. Ponciano surge, portanto, como uma releitura da tradição literária nacional.

Segundo Walter Benjamin (1983), o tradicional contador de histórias é representado por um homem experiente, sábio, que é ou viajante, aquele que compartilha os conhecimentos adquiridos em suas andanças, ou um camponês sedentário, conhecedor das 
particularidades do lugar em que habita. Figura respeitada pela comunidade, o narrador tradicional cumpre com uma função pedagógica ao transmitir conhecimentos e valores que serão repassados de geração em geração, por meio de suas narrativas exemplares buscadas na memória. Os narradores mais autênticos seriam ainda homens justos, simples e ativos, contadores de histórias desprovidos de exaltação mítica ou exageros no emprego do maravilhoso. Diante disso, percebe-se que Ponciano é o avesso desse tipo de narrador: em lugar da memória, da seriedade e da sobriedade, surgem a invenção, o cômico e o exagero. Hiperbólico tanto em sua própria figura quanto nas histórias mirabolantes que narra, o coronel não intenta transmitir conhecimentos - mesmo porque os forja -, mas sim se tornar notório e impressionar as pessoas, no que fracassa. Trata-se, portanto, de uma paródia do narrador tradicional.

Em um episódio exemplar dessa inversão, o coronel resolve assustar Juquinha Quintanilha, sujeito simples e de sua confiança, trabalhador de suas terras. Na ocasião, Juquinha havia o procurado a fim de lhe sugerir que contratasse um famoso capitão, para dar cabo de uma onça que aparecera nos arredores do Sobradinho e andava fazendo estragos. Ponciano se declarava, sob várias desculpas, impedido de realizar o serviço, contudo, vaidoso, também não queria permitir que alguém o fizesse por ele, ainda mais que seu empregado elogiara a valentia do tal capitão. Sentindo-se em desvantagem, a saída de Ponciano foi tentar diminuir a coragem que Juquinha atribuía ao caçador, desviando o assunto para um território em que se sentia seguro:

Disse a Juquinha que encurtasse tanta vantagem:

- Quero ver esse capitão numa pendência de lobisomem.

O mulato, medroso de perder a cor, resmungou que em noite de corisco nem era de religião cuidar de visagem. Mal acabou Juquinha de ministrar esse conselho, do fundo da varanda uma coruja cortou mortalha. Ou vinha corrida do vento ou então, desmedrosa do temporal, rondava o quarto dos santos, atraída pelo azeite das devoções. Embarquei no pio da agourenta de maneira a espicaçar o medo do mulato. Falei queixoso: 
- Não há mais respeito, não há mais nada. Qualquer noite a gente tem coruja de talher na unha comendo na mesa de Simeão. (Carvalho, 1983, p.38)

Diante da impotência ou da ameaça de parecer menos poderoso do que alguém, Ponciano recorre, portanto, ao mundo das assombrações. Para tanto, o coronel se vale do que aprendeu na infância, quando estivera sob os cuidados de sua prima Sinhá Azeredo, uma beata conhecedora de rezas para todos os males, apresentada no início da narrativa como uma contadora de histórias: "Por mal dos meus pecados, o que a prima mais apreciava era conversa de assombração, de meninos desbatizados que morriam sem o benefício da água benta ou de herege esquentando em fogueira de frade" (p.4). Assim, órfão desde menino, o desenvolvimento de Ponciano foi marcado pelos referenciais de poder e masculinidade que buscou em seu avô e também pela tendência a contar histórias, herança das crendices e medos que lhe foram incutidos por Sinhá Azeredo.

De volta à noite chuvosa do Sobradinho, Juquinha, solícito e já um pouco assustado, ofereceu-se para contratar um "rezador", para espantar as corujas. Mas, dizendo-se experiente em lidar com maldições, o coronel explicou ser desnecessário: “[...] era dizer, em três sextas-feiras seguidas, desde que havendo estrelas, o santo nome de Onofre: - Não fica uma. Seca tudo no galho. Ninho, asa, bico, o diabo!" (p.38). Nesse contexto de sincretismo religioso, em que catolicismo e crenças da cultura africana se misturam, bem ao gosto popular, Ponciano, auxiliado pelos ruídos da "noite trevosa", começou a fazer comentários procurando despertar medo em Juquinha. Ao ouvirem um barulho vindo dos fundos do casarão, semelhante ao arrastar de correntes, Ponciano sugeriu: "-Esquisito, hein, seu compadre? Parece corrente de negro cativo”. Juquinha já demonstrava sinais de medo, mas Ponciano sentia-se seguro para levar a brincadeira adiante, afinal, como acredita: "Mal-assombrado não era, que esse povo da noite nunca aparece na popa da tormenta. Seguro de tal verdade, contada e recontada em dias de sua vida pela prima Sinhá Azeredo, dei mais um passo na judiação de Quintanilha” (p.38-9). 
O próximo passo é outro indício de que não se está diante de um contador de histórias convencional, como os que se pautavam apenas na memória: o coronel pega um livro (de São Cipriano) e, enquanto Juquinha pensa que o patrão pretende fazer alguma oração para cessar a tormenta, Ponciano "ri no íntimo", abrindo-o em uma parte que já conhecia: "[...] o caso de uma penitência levada da breca que em tempos dos antigos pintou e bordou num sobrado de sujeito barão. Coisa acontecida num longe antigamente [...]" (p.39). Desse modo, se ao incorporar a figura do contador de histórias no romance recria-se uma tradição oral registrando-a pela escrita, nesse ponto ocorre o movimento inverso: ao invés de se valer de um conhecimento fixado na memória, advindo de uma transmissão oral, o contador de histórias recorre à palavra escrita para alcançar o efeito que deseja sobre seu ouvinte. Ponciano, no entanto, é um leitor transgressor e coopera com o livro para fazer a história se tornar mais aterrorizante:

Passei de largo, de vela solta, pelos receios de Juquinha Quintanilha. Puxei o lobisomem do livro de São Cipriano para dentro dos ouvidos dele. Uma assombração danada de um cristão lidar com ela. Uivava de cortar o coração mais de pedra. Digo que fiz chicana de doutor velho, pois não segui tintim por tintim o que a letra de forma estipulava. Pulei, misturei, inventei em favor do lobisomem maldade de arrepiar. Juquinha amarelou e no fundo da cadeira mais parecia um rato assustado. (p.39, grifos nossos)

Juquinha Quintanilha, que já havia escutado, além dessa história, a da aparição do falecido avô de Ponciano, decide ir se deitar, amedrontado, aconselhando o patrão a não "catucar" as maldições da noite. Sozinho agora na sala, na noite de tempestade, o coronel ri da "pantomima" que armou, até que de repente, quando comicamente agachado - procurando "em que nação" andava seu chinelo - escuta um barulho que seu avô costumava fazer por dores nas articulações em função do mau tempo ou, em suas palavras, uma "remessa de lamentos muito de meu avô quando o sul apertava as dobradiças 
dele" (p.40). O contador de histórias passa, agora, ironicamente de assustador a assustado:

Pulei de lado, que ligeiro sempre fui e ainda sou neste dobrar da vida, em pulo tão avantajado que levei na frente o tal cachorro corrido do temporal. [...] mas na porta do corredor fiz pé firme. Não ia ser gemido avulso de fundo de casa que podia mandar o neto de Simeão aos cobertores, como qualquer Juquinha Quintanilha. Acalmado, inquiri:

- Quem tem o desplante de brincar a estas horas? Se é gente viva, que apareça, pois não faço reprimenda. Se é coisa morta, falecida de cemitério, que vá fazer penitência no oratório do Sobradinho. (p.40)

Embora Ponciano não obtenha resposta, o cachorro mencionado (que estava na sala se abrigando da chuva desde a cena com Juquinha) olhava com pavor na direção da antiga cadeira do falecido Simeão: "Olhava e gemia um gemido comprido de ser medido a metro. Foi quando vi, refestelado em seu assento como em dias de sua vida, o avô Simeão de Azeredo Furtado. [...] Fiquei sem poder tirar o olho do meu avô presente em forma de renda [...]" (p.40). Ponciano, que relatara já ter ouvido a prima Sinhá Azeredo tossindo pela casa depois de morta, agora está diante do espírito de seu avô. "Seria imaginação? Sonho?", indaga-se o leitor incrédulo à procura de uma explicação racional para o fenômeno, já que Ponciano, dessa vez, não teria motivo aparente para estar mentindo. Explica o coronel Ponciano, agora sentindo-se um menino amedrontado diante de seu avô:

Só dava conta de não estar em pesadelo pelo motivo de sentir, em debaixo do sofá, o choro agoniado do cachorro e o assobio do vento. Tentei chamar Quintanilha - a voz deste coronel respeitou a presença do velho, pelo que saiu fraca [...]. Fica provado, para todos os devidos fins, que eu só sabia manobrar assombração de fora. Diante de uma visagem de família, ficava de pé amarrado [...]. (p.41) 
O mais engraçado, no entanto, José Cândido guardou para o final desse "causo" às avessas, em que o próprio contador se torna motivo de riso. O corajoso coronel já iria "bater em retirada" quando é surpreendido por um imenso clarão, que o permite ver que seu avô está usando botas e esporas: "Então, sem mais delongas, abri em risadaria, despido de receios e considerações de parente" (p.41). Com isso, instala-se um momento de anticlímax na narrativa, já que, mesmo ainda vendo Simeão, o coronel perde o medo. Afinal, o que o leva a perder o medo do que vê? Para compartilhar sua descoberta, ele chega a chamar por Juquinha que, já "escondido no cobertor", não lhe responde:

Queria que o medroso visse, com os olhos de morrer, a invencionice do Sobradinho. Que mal-assombrado, que nada! Matei a charada num repente, por saber da leitura dos livros e das conversas da prima Sinhá Azeredo, que visagem anda sem pé e voa sem asa. Nunca que Simeão ia aparecer de perna inteira, quanto mais em desplante de bota e espora! Tudo não passava de bobagem, enganamento, mentira da noite trevosa. E com essa certeza dormi em sossego. (p.41-2)

Nesse ponto, o caso aproxima-se dos procedimentos narrativos da piada, como acontece em vários contos de José Cândido. Em um deles (Carvalho, 2010) as pessoas contam histórias de assombração em volta de uma fogueira, mas uma das narrativas é tão assustadora que um dos ouvintes sai voando de medo - voando, pois, na verdade, era um fantasma. A ironia dessa passagem do romance é semelhante. Ponciano mostra-se, nessa cena, tão supersticioso e convicto de suas crendices que, agora, realmente diante de uma assombração, busca argumentos nos conhecimentos que adquiriu sobre eventos sobrenaturais para explicar o que seus olhos veem. Enquanto Ponciano se tranquiliza, acreditando ter se assustado inutilmente, o autor implícito do texto, pelo recurso da ironia, dá uma "piscadela" ao leitor, com quem partilha uma visão mais ampla dos fatos. Note-se que dessa vez não se tratava de uma "invencione" do coronel, 
mas sim do próprio Sobradinho. Além disso, o cão presente na cena não é elemento gratuito, antes é a testemunha ocular do evento sobrenatural. Ou isso, ou seria necessário aceitar que Ponciano teve um delírio, o que não encontra sentido quando se considera o efeito cômico final do episódio. Assim, só resta admitir que, mesmo sendo o coronel um contador de histórias, há passagens em que os eventos sobrenaturais se impõem como "realidades" no interior da narrativa, corroborando a junção entre plano fantástico e real, tal como reconheceram Antonio Candido e Ángel Rama sobre essa nova roupagem da ficção regionalista.

Por essa dimensão "verdadeiramente sobrenatural" que a narrativa comporta, assegurada ainda pelo caráter insólito do plano macro de enunciação da obra, torna-se viável estabelecer um contraponto entre esse romance de José Cândido e os contos Histórias de Alexandre, de Graciliano Ramos. Escritos no final da década de 1930 e lançados em 1945, esses contos foram depois republicados com outras narrativas do autor em 1962, em um volume intitulado Alexandre e outros heróis. Nesses contos (Ramos, 1991a), o autor do calado Fabiano, de Vidas secas, cria a figura de Alexandre, um velho contador de histórias do sertão nordestino. Embora o escritor, pelo uso abundante dos diálogos, transfira com frequência a voz narrativa para esse protagonista contador de casos, existe um narrador em terceira pessoa responsável por controlar as informações do contexto, descrevendo o ambiente em que as histórias são narradas. Toda a esterilidade imaginativa e o bloqueio linguístico de Fabiano são revertidos em um caudal de histórias fantasiosas e mirabolantes, que ganham vida na fala de Alexandre. No entanto, essas personagens de diferentes caracterizações são unidas por um pano de fundo de extrema pobreza, que denuncia as condições de degradação e carência material em que ambas se encontram. Assim, Graciliano expõe, por meios distintos, as mazelas resultantes de um mesmo problema social, que se repete nas regiões mais afetadas pelo subdesenvolvimento brasileiro: seja pela incapacidade de sonhar com outras realidades ou, o avesso disso, pela imaginação criadora de mundos onde tudo é possível, a denúncia se impõe, apontando a mudança como sinônimo de utopia. 
Diante disso, poder-se-ia questionar, aparentemente, a validade da distinção que Alfredo Bosi (1988) estabelece entre a prosa de Graciliano Ramos e a de Guimarães Rosa, com base no argumento de que o primeiro rejeita o universo mágico dos sertanejos, enquanto o segundo incorpora esse mesmo universo. No entanto - e é por isso que se convocou o exemplo aqui-, as histórias de Alexandre não fornecem, necessariamente, uma dimensão mágica à narrativa, capaz de compor um plano em que real e sobrenatural se imbriquem. As histórias heroicas, fantasiosas e exageradas do discurso de Alexandre são claramente forjadas e se apresentam, justamente, em contraste com a realidade de miséria e precariedade que o cerca. Trata-se de uma evasão da personagem para a imaginação, como forma de compensar carências insolúveis em outros níveis - o que não implica um padrão de representação distanciado da estética realista, pautada na verossimilhança. Confirma-se, assim, a distância, também defendida por Zilá Bernd (1998), entre a modalidade de representação da prosa do escritor alagoano e a do mineiro.

O romance de José Cândido de Carvalho mantém, por sua vez, vários pontos de contato com os contos de Graciliano: Ponciano também é um contador de histórias fantasiosas, exageradas, mirabolantes, por meio das quais encontra um modo de compensar suas fragilidades, seus medos e a perda de seu poder e influência. Ponciano conta suas histórias para demonstrar sabedoria, experiência, conquistar respeito como um homem de coragem e valentia, impressionar seus subalternos, seus amigos e suas pretendentes. Ressalte-se ainda que, como Ponciano, Alexandre diz também ter sido militar, o "major Alexandre" (Ramos, 1991, p.75). Assim, a decadência dessas personagens retrata o declínio de figuras de prestígio no meio rural, em tempos em que vão desaparecendo as condições para sua existência. A despeito das diferentes regiões geográficas em que se passam as histórias desses heróis (Nordeste e Sudeste), como os cenários são áreas interioranas de um Brasil agrário, os motivos que percorrem os "causos" de Ponciano e Alexandre são também bastante semelhantes, de modo que elementos do imaginário popular rural, como onças ferozes e cobras descomunais, se fazem presentes nas narrativas. 
Na cena transcrita a seguir, Alexandre conta aos seus ouvintes entre eles o desconfiado cego Firmino, com quem tem de argumentar para assegurar a veracidade de seu relato - uma história sobre sua valentia ao matar uma temida cascavel:

- [...] Puxei a rédea, parei, ouvi um barulho de guizo, virei-me para saber de que se tratava e avistei uma cascavel assanhada, enorme, com dois metros de comprimento.

- Dois metros, seu Alexandre? Inquiriu o cego preto Firmino. Talvez seja muito.

- Espere, seu Firmino, bradou Alexandre zangado. Quem viu a cobra foi o senhor ou fui eu?

- Foi o senhor, confessou o negro.

- Então escute [...]. Machuquei-lhe a cabeça com o salto da bota. Estrebuchou, fez o que pôde para arrumar-se em novelo, depois se aquietou e ficou estirada na poeira. Baixei-me e medi o corpo mole: nove palmos e meio espichados. Isto é com o senhor, seu Firmino. Nove palmos e meio, entendeu? [...] Vá buscar o cachimbo, Cesária. E procure o chocalho da cascavel, que você guardou. (Ramos, 1991, p.40-2)

Dos ouvintes de Alexandre, vizinhos e amigos, o cego Firmino é o que mais "vê" as mentiras e questiona as contradições e os exageros do contador. Apesar disso, mantém-se uma aura de autoridade na fala de Alexandre que, além de ser respeitado por sua plateia, conta com o apoio de Cesária, sua esposa e cúmplice, que tudo confirma, remenda, evitando ver o marido em apuros com as histórias inventadas. Observe-se que o coronel Ponciano, por sua vez, também "é dos uns que mata a cobra e mostra o pau” (Carvalho, 1983, p.109), pois possui "provas cabais" de suas façanhas, como um cacho de cabelo loiro da sereia, que com ele queria se casar (p.109), e o tapete de sua sala, a pele da onça que ele diz ter matado - fama imerecida, já que o coronel confessa ter sido um menino dos pastos, brincando com uma espingarda, que deu fim ao animal - "Ficou comigo a fama e a escama de ter dado exterminação ao gato. [...] Como lembrança do 
sucedido, mandei espichar na sala do Sobradinho a pele curtida do gatão [...]"p.62).

Já o caso da cobra contado pelo coronel é ainda mais exagerado do que o narrado por Alexandre, mas nem por isso ele é questionado por seus ouvintes. É preciso lembrar, nesse sentido, que Ponciano é aqui ainda o "coronel" Ponciano da primeira metade do romance, homem respeitado por aqueles que o cercam e que tem por ouvintes os habitantes do campo. Embora não seja o protagonista do feito, o coronel se utiliza da história exagerada para se destacar, demonstrando sua autoridade no assunto, em relação a outro contador de casos com quem não simpatiza, já que este ameaça seu posto de homem conhecedor dos "sucedidos dos ermos":

[...] tive de repelir certa braçada de inventados de um limpador de pasto de Badejo dos Santos, que escumava mentira sem pejo de ser pegado em falso. Garantiu ter dado cabo de uma cobra de seus duzentos palmos de tamanho e trinta arrobas de peso:

- Provo mostrando a pele.

Nas bochechas dele desfiz do serpentão com o caso de uma monstrona que apareceu no mandiocal de Santinho Belo, primo afastado do avô Simeão. A danosa devia ter vindo das águas do mar salgado, porque pasto nenhum, por mais viçoso, podia aguentar exageramento de tal calibre. Morta a bicha, dois dias e duas noites o povo de Santinho Belo não fez outro trabalho que não puxar rolete de cobra do seu fundo covil. Foi um tirar de serpente sem fim. A pele, vendida no comércio de espichados, comportou mais de dúzias de cintos dos largos e ainda rendeu um tapete de sala [...].

O sujeito, que dava mostra de entender do riscado, concordou:

- Do modo falado pelo coronel, só podia de ser mesmo a tal serpentona do mar. (Carvalho, 1983, p.127)

Apesar de todos os exageros e a inverossimilhança das histórias que contam, o major Alexandre e o coronel Ponciano preocupam-se com a sua credibilidade e o efeito de convencimento que produzem na plateia. Assim, tentam ainda argumentar que se sentem 
incomodados com a proporção que suas histórias tomam, ao serem transmitidas e destorcidas por outras pessoas, levando a um exagero que não condiz com a "verdade" dos fatos:

[... Mas se quiserem saber a minha fama no sertão, deem um salto à ribeira do Navio e falem no major Alexandre. Cinquenta léguas em redor, de avante a ré, todo o bichinho dará notícia das minhas estrepolias. A história da onça, a do bode, o estribo de prata, este olho torto, que ficou muitas horas espetado num espinho, roído pelas formigas, circulam como dinheiro de cobre, tudo exagerado. É o que me aborrece, não gosto de exageros. Quero que digam só o que fiz. (Ramos, 1991, p.75-6)

[...] Não sou, como todo mundo sabe e conhece, loroteiro ou espalhador de falsos. (Carvalho, 1983, p.18)

Por não ser de minha natureza vestir glória dos alheios, desmenti [...]. Pois logo espalharam que eu apresentava essas modéstias para não dar parte de sujeito quebrador de promessas. Diante disso, lavei as mãos. (Carvalho, 1983, p.62)

Pelas semelhanças dos protagonistas contadores de história, reconhece-se que o romance de José Cândido se inscreve como um continuador dessa linhagem da literatura regionalista, em que também se situam esses contos de Graciliano Ramos. Porém, o coronel contador de histórias, ao assumir a voz narrativa do romance, acaba investindo de irrealidade e magia o tipo de representação da obra, diferente do que ocorre nos contos de Alexandre, em que os eventos sobrenaturais são apresentados pelo narrador como mentira e fabulação. A dimensão insólita do romance de José Cândido manifesta-se não apenas pelo desfecho de incontestável caráter mágico da narrativa, mas também, conforme demonstrado, pelos eventos sobrenaturais que permeiam momentos da realidade das personagens, sobretudo na primeira metade do livro, em harmonia com o universo imaginário de Ponciano e dos demais habitantes das áreas rurais. 
Embora o coronel Ponciano se coloque muitas vezes em uma posição superior à ingenuidade do "povo do sertão" e suas crendices, ele de fato acredita (ou até passa a acreditar) em muito do que conta para impressionar ou assustar as pessoas. Diferentemente de Alexandre, Ponciano passa por situações, para além de seus "causos", em que sua coragem e valentia são testadas. Medroso quando menino, assustado pelas histórias sobrenaturais contadas por sua prima Sinhá Azeredo que ecoam por toda sua vida adulta, Ponciano cresce, na verdade, em crise com suas crenças, oscilando entre um pensamento mítico, supersticioso, ligado à primitividade e à cultura popular, e outro, cético e racional, relacionado à modernidade, à civilização urbana $e$ ao conhecimento formal. Por ser claramente um contador de histórias, poder-se-ia afirmar que só utiliza as narrativas fantasiosas a seu favor, mentindo sem nelas crer; no entanto, seu comportamento nega esse fato quando se mostra amedrontado diante de situações em que ou o sobrenatural se manifesta ou se encontra em potencial.

Exemplo disso se dá na ocasião em que o coronel é convidado a ir até a propriedade de um amigo, o major Serapião Lorena, para resolver o caso do aparecimento de um ururau. Durante o jantar servido na casa de Lorena, um rapaz provocava Ponciano, advertindo que o animal assombrado era um dos piores já vistos no lugar, pois soltava fogo. O coronel, debochando da "invenção" do rapaz, responde à provocação: "Pois não quero ser Ponciano de Azeredo Furtado se não avivar meu charuto na brasa do amarelão" (Carvalho, 1983, p.99). Logo depois do envaidecimento, sua pretensa descrença e valentia são postas à prova por uma situação inesperada que o desmascara, de forma que a ironia se impõe novamente como procedimento narrativo, instaurando a comicidade da cena:

Mal acabei o resto da promessa, sobreveio um vento encanado e a lingueta do lampião alongou e morreu. No denegrido da sala, como coisa vinda das profundas do mar salgado, cresceu aquele ronco de gelar o ânimo mais saído. E tanto era coisa aparentada das águas que logo um cheiro de maresia e lodo deu entrada no recinto. O major abriu o peito: 
-É ele! Credo em cruz! É o ururau!

Um atropelado de gente em debandada entupiu o corredor, que para abrir caminho tive de usar da força bruta. Quando dei acordo de mim, andava no meio da desordem em lugar subalterno, atrás de uns balaios, na despensa de Lorena. E no calcanhar da arruaça apareceu aquele toco de preta munida com lamparina. Parou admirada de presenciar tanto ajuntamento de homem em compartimento de cozinha, cada qual mais escondido entre mantas de carne-seca e outras mantenças. Sou lesto de ideia e pronto salvei a honra dos assustados inventando que tal proceder era por motivo de pregar peça em Juca Azeredo, que já devia, pelo tempo, estar na sala chegado. E antes que a subalterna entrasse em pormenor e indagação, mandei, dedo apontado para o corredor, que fosse esperar a visita:

- Vá lá dentro fazer a cortesia a ele. (p.100)

Ponciano ainda pede covardemente à agregada de Lorena que confira a parte da frente da casa, de onde o som parecia ter vindo. Só depois de esclarecido o caso - era só um trovão e vento, em função do mau tempo -, o coronel recobra a aparência de homem corajoso, e ainda acusa, intimamente, os demais de medrosos e covardes: "Que ururau, que nada! O povinho de Lorena tinha arrepiado pé na frente de um trovão recaído de mau jeito no derredor da casa. Era no que dava lidar com gente espantada. [...] cambada de mariquinhas, magote de assombrados” (p.100). Sentados novamente à mesa, Ponciano pondera que, como visita, seria melhor não ofendê-los e muda de estratégia: dizendo-se "sujeito humanal", ainda tenta levantar o ânimo dos amedrontados, dos quais, é claro, se exclui. Reestabelecendo sua pose de homem valente, valoriza o modo como procederam, já que teria sido tolice enfrentar, "no peito e na raiva, o amarelão" (p.101).

Desse modo, às tentativas do coronel de parecer racional, revela-se uma mentalidade mítica, nele definitivamente incutida. Assim, o extraordinário, mesmo quando não chega a se manifestar, permanece em estado latente em decorrência do imaginário mítico do narrador e de seu grupo: "Não foi o ururau, mas podia ser" (p.101-2). 
É como se uma espécie de semicrença sintetizada no provérbio espanhol "No creo en brujas, pero que las hay, las hay" estivesse na base, na constituição psíquica de Ponciano. Se em um momento afirma que muito do que ouve não passa "de garganta, saliva de curral" (p.46), em seguida já se vê denunciando seus medos e crenças, o que faz dele um homem dividido entre uma consciência mítica e outra racional. O ex-jagunço Riobaldo também distingue-se dos demais habitantes do sertão chamando-os "povo prascóvio", logo no início do romance, mas, por outro lado, vive atormentado com o possível pacto estabelecido com o diabo. Por isso, o coronel não se encontra muito distante do dilema existencial de Riobaldo (o diabo existe?) e das questões que se manifestam com mais contundência e clareza para o narrador rosiano. Para Eduardo F. Coutinho, a crença no sobrenatural é um dos traços mais proeminentes do sincretismo religioso da América Latina, resultado dos processos de transculturação entre povos com diversos costumes, religiões e mitos. $\mathrm{O}$ crítico comenta a relevância dessa dimensão no romance de Guimarães Rosa:

O fato de que o sertão representado no Grande sertão: veredas é um mundo ilógico no sentido de que se situa em uma esfera que transcende as barreiras impostas pelo pensamento racionalista torna-se evidente no romance se pensarmos naqueles elementos que formam o complexo mental dos habitantes da região, a saber, seu misticismo, crenças e superstições, e a maneira de relacionar-se uns com os outros e com os fatos e eventos exteriores. Embora pareça irrelevante enumerar esses elementos aqui ou mesmo os discutir separadamente, por configurarem a atmosfera que invade o romance inteiro, cabe mencionar que eles se estendem de meras superstições e premonições até a crença em aparições e o respeito quase religioso pelos curandeiros e adivinhos. Dentre esses elementos, o que mais se destaca, chegando a constituir um dos principais temas da narrativa, é o temor ao diabo, sempre presente em sua ausência, que "não há, havendo", como afirma Riobaldo frequentemente. (Coutinho, 2013, p.115, grifos nossos) 
Portanto, na medida em que o romance de José Cândido afasta-se da prosa de Graciliano, aproxima-se da de Guimarães Rosa, no sentido do espaço concedido por ambos à vivência de uma dimensão insólita, aparente em um novo tipo de representação da prosa regionalista. Não se trata de um universo mágico que ganha forma apenas nos "causos" dos narradores, é antes parte integrante de suas visões de mundo, de um modo mítico de experimentar e interpretar os fatos. Para Zilá Bernd, é com O coronel e o lobisomem que se chega a um momento da prosa brasileira de plena adesão ao imaginário mágico popular.

Nesse sentido, a distância irônica que se apontou entre a voz do autor implícito e a de Ponciano, enquanto narrador infiel, não é utilizada para negar o modo mágico do homem rústico de entender o mundo, sobrepondo-lhe uma perspectiva racional, uma vez que, na cena do fantasma de Simeão, o sobrenatural afirma-se mesmo diante da discordância do herói. O narrador infiel e a ironia enquanto recurso narrativo convergem para a construção do humor, revelando que, ao invés da valentia, coragem e sagacidade propaladas, Ponciano se caracteriza pela fragilidade, medo e ingenuidade. Contudo, o autor implícito distancia-se desse narrador menos para condená-lo por essa ingenuidade e por suas crenças, que para denunciar uma contraditória e traiçoeira conjuntura do processo de modernização, responsável por sua alienação e marginalidade. Ao fazê-lo, ao criticar os impasses de uma sociedade capitalista que só pode se consolidar pela exclusão, o romance de José Cândido rompe com o padrão estético realista tradicional, revelando a realidade por um novo ângulo: a perspectiva dos que estão em conflito com as transformações impostas pela modernização, dos que têm dificuldade em lidar com suas crenças, valores e comportamentos diante de um mundo cético, desencantado e reificado. Desse modo, recria-se artisticamente uma perspectiva mágico-popular no âmbito da representação, retrocedendo a formas de pensar que se opõem ao racionalismo burguês.

Ao discutir o imaginário que enforma essas obras, passa-se a adentrar o terceiro nível, o terreno que Ángel Rama (2004) considera como a "cosmovisão" dos romances da transculturação narrativa. 
Sem perder de vista a unidade entre os três níveis, nesse plano são engendrados os significados e as ideologias de resistência que as narrativas da transculturação manifestam em relação à modernidade. No cenário ficcional anterior ao dos transculturadores, o vanguardismo (a primeira fase do modernismo, no caso brasileiro) teria questionado o discurso lógico-racionalista, que até então era utilizado pelo romance nacional em consequência da origem burguesa do gênero. A obra de Graciliano Ramos, que aparece na sequência, embora ainda orientada por esse discurso, manifestava uma mensagem combativa e antiburguesa, já aliada a uma linguagem e estrutura renovadas. No entanto, seria a produção dos escritores transculturadores que mais decisivamente colocaria em xeque esse padrão lógico-racional, uma vez que os autores se voltavam às fontes da invenção mítica, segundo o crítico, inextinguíveis em todas as sociedades humanas, mas ainda mais vivas nas comunidades rurais. Para a construção dessa perspectiva de recusa à razão teriam colaborado os estudos sobre o mito, os quais foram importados junto às tendências modernizadoras. Os transculturadores, porém, não só "manejaram" o mito, explica Rama, mas passaram a indagar pelos mecanismos mentais capazes de o gerar, o que os levou a um exercício do "pensar mítico":

Os transculturadores descobrirão o mito. Porém, essa descoberta não será feita de acordo com as espécies da narrativa culta da época [...], mas sim com um repertório quase fabuloso de elementos que não haviam sido explorados nem utilizados livremente pela literatura narrativa do regionalismo, embora vivessem ao lado dele. Contudo, mais importante ainda que a recuperação de elementos em estado de incessante emergência é a descoberta dos mecanismos mentais geradores do mito, o retorno a essa camada aparentemente sepultada, mas de enorme potencialidade, na qual se desenvolvem as ações míticas. (Rama, 2001, p.223-4, grifos nossos)

Alguns estudos compartilham, indiretamente, dessa perspectiva crítico-teórica proposta por Ángel Rama e Antonio Candido, segundo a qual o romance latino-americano de meados do século XX 
se caracteriza pela articulação de um plano histórico e realista a outro inverossímil, inclinado ao mítico, tal como se visualiza em O coronel e o lobisomem. Como denominador comum dessas propostas, encontra-se, grosso modo, a ideia de que um estilo artístico, uma tendência literária, é capaz de revelar e - o mais importante reinventar o espírito histórico de uma época. Nesse sentido, serão apresentados a seguir alguns desses pontos de vista, selecionados por potencializarem a capacidade hermenêutica das formulações de Rama e Candido e, com isso, propiciarem uma fundamentação mais consistente à continuação da abordagem do romance de José Cândido.

Segundo Octavio Ianni (1991, p.56), que adota a expressão "realismo mágico" para se referir ao momento literário em questão, essa produção se caracteriza por apresentar uma "aura surpreendente, insólita, demoníaca, encantada”. Para o crítico, trata-se de uma literatura que parodia e subverte categorias correntes do pensamento religioso, filosófico, científico ou artístico: "o senso comum, o catolicismo, o protestantismo, o calvinismo e outras modalidades de expressão ou articulação do ser, visões de mundo, são enfeitiçadas, satanizadas, encantadas, carnavalizadas, paganizadas" (Ianni, 1991, p.57). A composição de $O$ coronel e o lobisomem revela, de fato, algumas dessas dimensões, em uma mistura de magia e subversão das perspectivas convencionais. A cosmovisão mítica do coronel e das pessoas com quem convive no campo encontra suas bases em um sincretismo religioso que permeia toda a obra, misto de influências do catolicismo popular, de crenças africanas e indígenas, formadoras das lendas e das superstições pagãs do repertório latino-americano. Isso é o que revela uma cena em que Ponciano se irrita com o fato de Dioguinho do Poço advertir sobre o aparecimento de uma onça que "deitava fogo pela goela" (Carvalho, 1983, p.30). O coronel esbraveja com o vizinho, tomando como absurda a ideia. Note-se a insistência da discordância do coronel e aquilo que acaba, ironicamente, propondo ao final: 
- Que fogo que nada, Seu Dioguinho. Tenha respeito!

[...] Que negócio era esse de onça cuspir labareda? Era mesmo o que faltava! Dioguinho do Poço, dono de invernada, pai de menina já em ponto de tomar responsabilidade, de carreira arrepiada na frente do gatão:

-É demais, Seu Dioguinho. É demais! $[\ldots]$

- Seu Dioguinho, onde é que já se viu palhaçada mais vistosa? Onça de lamparina no gargalo!

[...] Sua voz [de Dioguinho] de atulhar os recintos mais largos, feita de todas as brutezas dos ermos, saltou em defesa do fogareiro da pintada. Que eu desculpasse, mas que muito povo do sertão, gente sem mentira e invencionismo, viu o alumiado, isso viu. Era um pedação de onça munida dos maiores desatinos [...].

Em fala de amizade, com Dioguinho em passeio pelos arredores das casuarinas, tirei da ideia dele a invenção da lamparina. Era bobagem, carochinha que não calhava num homem madurão e vivido. O que de fato largava fogo pela goela era o artimanhoso do dragão, maldade desaparecida desde o dia que o milagroso São Jorge do cavalo branco andou pelo mundo:

- Esse e mais outro bicho nenhum, seu compadre. (Carvalho, 1983, p.30, grifos nossos)

A indignação do coronel, as acusações de ser o caso uma "invenção", história da "carochinha", leva o leitor a pensar que acompanha um momento de ceticismo da personagem. No entanto, a explicação de Ponciano, revertendo o pensamento racionalista aparente e o senso comum, termina por confirmar um ponto de vista tão mítico quanto o de Dioguinho. Ponciano, na realidade, é uma representação paródica de uma ideia da identidade popular latino-americana e, mais especificamente, brasileira: homem que se diz batizado, católico, mas que conversa com espíritos, acredita em lendas e simpatias; além disso, é uma figura carnavalizada que oscila entre o sacro e o profano, entre o divino e o terreno, entre a pureza e a luxúria. Assim, se mal acaba de carregar o andor durante 
as procissões religiosas, logo retorna ao "viver descuidoso" dos cafés, casas de jogos e pensões "de moças desencaminhadas” (Carvalho, 1983, p.13).

Octávio Ianni aponta ainda a imaginação popular (a campesina ou a das culturas africanas e indígenas) como fator fundamental da produção latino-americana, por ser capaz de unir as dimensões do sonho e da realidade compondo uma espécie de "super-realidade" (Ianni, 1991, p.64). Nesse sentido, assim como Rama (2004), Ianni ressalta que os mitos constituem-se como mecanismos para a apreensão do real, na medida em que expressam "representações coletivas", ou seja, os mitos contribuem para a formação de uma determinada cosmovisão. O olhar mítico corresponde, então, a um modo inusitado de apreensão da realidade. Assim, nessa literatura, um fato mágico ou insólito pode desvendar dimensões recônditas e significados implícitos de uma determinada cultura, vida social, biografia ou história. Logo, ao se nutrir das diversas formas de manifestação cultural, o estilo artístico poderia ser visto tanto como uma "invenção mágica do real" quanto como um "modo de ser de uma época”:

É claro que o estado social de uma época, compreendendo as suas diversidades, ambiguidades e antagonismos, bem como as suas realizações e os seus impasses, não repercute imediatamente no romance, poesia, teatro, cinema, pintura, música. As condições sociais, econômicas e políticas da época ressoam na arte pela mediação da cultura. A realidade social sempre se expressa em relatos, descrições, explicações, narrações, estórias, boatos, lendas, fantasias, mitos; envolvendo palavras, sons, ritmos, traços, cores, gestos, expressões, imagens, metáforas. E é esse vivo acervo cultural, mesclando presente e passado, ciência, filosofia e magia, universais e singulares, que constitui o vasto arsenal de materiais, relações e significados, do qual se alimenta o artista, no qual a imaginação do artista se nutre. Assim, o estado social de uma época aparece e decanta-se na literatura, como em outras formas de expressão artística. (Ianni, 1991, p.70-1, grifos nossos) 
Sob essa perspectiva, o crítico propõe que as lutas sociais, em suas diversas formas, mas em especial a revolução popular do século XX, sejam a razão para a descoberta das dimensões mágicas, fantásticas, barrocas e grotescas da cultura. Nesse processo, Ianni tem em vista que o despertar dos povos latino-americanos para com a própria realidade revelou na arte dimensões ocultas de suas crenças, ilusões, fantasias, demônios, encantamentos. Nessa ideia ecoa a proposta de Antonio Candido (1989), sobre o super-regionalismo, momento em que se atinge, na produção da América Latina, uma consciência dilacerada do subdesenvolvimento. Assim, Ianni considera igualmente os problemas sociais que se impuseram em decorrência da rápida modificação desses países, gerando parcelas da população que não puderam se adaptar às transformações e que, por essa razão, se viram excluídas pelo sistema. Diante disso, o realismo mágico, para o autor (Ianni, 1991, p.73), corresponde a uma visão crítica da cultura, da realidade social e da história, expressa pelo rompimento com as noções e formas de pensamento racionalistas oriundas da sociedade capitalista burguesa: tempo, espaço, vozes, figuras, hierarquias de poder, tudo passa a ser revisto pelo crivo paródico da fantasia e da imaginação.

Perspectiva semelhante é a adotada pelo crítico William Spindler (1993), ao propor uma tipologia para obras do chamado realismo mágico. Em geral, os traços apontados até agora como recorrentes na ficção do período por Candido (1989), Rama (2004) e Ianni (1991), e também por Dacanal (1970), Zilberman (1977) e Bernd (1998) - traços como a espacialidade rural, a perspectiva popular, a cosmovisão mítica, a construção de uma imagem da realidade fora dos padrões realistas, a convivência entre logos e mythos - correspondem ao que Spindler (1993) denominou "realismo mágico antropológico". Tomando a expressão realismo mágico como uma categoria estética, mas reconhecendo a polêmica em relação a seu uso pela crítica, Spindler defende que as obras assim comumente identificadas apresentam certa constância temática, formal e estrutural, que exige diferenciá-las de outras modalidades próximas, como o surrealismo e o fantástico. O adjetivo "antropológico" que o crítico 
agrega à expressão diferencia, conforme explica, esse tipo de "mágico" dos outros dois propostos em sua tipologia, a saber, o metafísico e o ontológico.

Spindler (1993, p.8) sugere que por "realismo mágico antropológico" possam se indicar as obras que mostram o contraste entre a atmosfera estagnante das comunidades rurais ou provincianas e a imaginação vívida de seus habitantes. No caso da literatura brasileira, essas personagens teriam suas vidas afetadas por ecos de um passado escravagista e, como descendentes de escravos ou em contato com eles, se veriam influenciadas em suas ações e comportamentos por crenças mágicas. Em vista desse misticismo relacionado à cultura popular, Spindler (1993, p.9) constata também que essas narrativas se distinguem pela "existência de uma 'consciência mágica' nos personagens, que é observada pelo autor como igual ou superior ao racionalismo ocidental". O narrador, por sua vez, apresenta uma dualidade de vozes, ao relatar os acontecimentos ora de um ponto de vista racional (realista), ora de outro, crente em magia (mágico). Essa antinomia, no entanto, seria resolvida quando o escritor se refere aos mitos compartilhados pelo imaginário de determinado grupo étnico ou social. Para o crítico, essa ficção que apresenta uma cosmovisão mítica em convivência com uma mentalidade racional moderna não é peculiar à América Latina, manifestando-se também em regiões periféricas que enfrentam conflitos sociais semelhantes aos desse continente:

De fato, a força do Realismo Mágico na "periferia” (América Latina, África, Caribe) e sua comparativa fraqueza no "centro" (Europa Ocidental, Estados Unidos), poderia ser explicado pelo fato de que mitos coletivos adquirem maior importância na criação de novas identidades nacionais, bem como o fato mais óbvio de que crenças pré-industriais ainda representam uma parte importante na vida cultural e sociopolítica dos países em desenvolvimento. O Realismo Mágico dá o mesmo grau de importância à cultura popular e às crenças mágicas que os ocidentais dão à ciência e à racionalidade. Ao fazer isso, são favorecidas as reivindicações de igualdade daqueles 
que mantém essas crenças com as elites modernizadoras que os governam. (Spindler, 1993, p.9-10, grifos nossos)

Observe-se que Spindler tem em vista, assim como os demais autores, as condições de subdesenvolvimento e desigualdade social das áreas periféricas em que tal ficção combativa se manifesta. $\mathrm{Na}$ base dessa produção está a valorização das crenças mágicas da cultura popular, em uma atitude de questionamento do racionalismo modernizador. Nesse contexto, segundo o autor, os mitos surgem como elemento importante à criação das "identidades nacionais" desses povos. Essa ideia encontra ressonância também entre outros críticos que avaliaram esse mesmo fenômeno estético.

Com efeito, também para o pesquisador Erik Camayd-Freixas (1998), a ficção do realismo mágico apresenta uma cosmovisão mítica de resistência ao racionalismo e à crença no progresso, relacionada às fontes primitivas e à cultura popular. Segundo o autor, contribuiu para a formação dessa ideologia o relativismo cultural promovido por uma nova perspectiva dos estudos antropológicos, que passaram então a questionar as bases epistemológicas do racionalismo moderno. Além disso, o autor explica que os grandes ensaios de interpretação nacional e continental tiveram seu ápice entre as décadas de 1930 e 1950, criando uma atmosfera cultural favorável ao questionamento da realidade desenvolvido pelos ficcionistas. Por certo, como se verifica no caso brasileiro, nesse período que antecede a publicação do romance de José Cândido, emerge uma importante bibliografia em diversas áreas do conhecimento acerca da condição nacional: Casa grande Ė senzala, de Gilberto Freyre, é publicado em 1933; Raízes do Brasil, de Sérgio Buarque de Holanda, em 1936; Formação do Brasil contemporâneo, de Caio Prado Jr., em 1942; Coronelismo, enxada e voto, de Victor Nunes Leal, em 1948; Os donos do poder: formação do patronato político brasileiro, de Raymundo Faoro, em 1958; Formação econômica do Brasil, de Celso Furtado, em 1959; e Formação da literatura brasileira, de Antonio Candido, em 1959.

Desse modo, de forma semelhante a Rama, Ianni e Spindler, Camayd-Freixas (1998, p.11) propõe que a dimensão mágica dessa 
ficção, assegurada pelo mito, permite um duplo nível de significação a esses textos, sendo um literal e outro figurado. Nesse nível, se daria o que chamou "alegoria histórica": a perspectiva mágico-primitiva distancia a narração das formas miméticas do realismo tradicional, sem abandonar a realidade sócio-histórica, que reaparece, alegorizada pela ficção. Assim, segundo o autor, o mágico se converte em metáfora do real, e o mito, em alegoria da história americana. Essa alegoria, no entanto, apresenta relações menos nítidas em relação à alegoria tradicional:

En comparación con la alegoría tradicional, el realismo mágico muestra relaciones menos nítidas, más fragmentadas y difíciles. Peter Bürger ha observado que ese extremo fragmentarismo alegórico es característico del arte de vanguardia [...]. Primero, la alegoría saca un elemento de la totalidad del contexto vital, lo aísla, y lo despoja de su función original. La imagen alegórica es un fragmento, y es por tanto esencialmente opuesta al símbolo, que es orgánico. Luego, la alegoría reúne los fragmentos aislados de realidad y crea así um significado, pero un significado construido, que no se deriva ya del contexto original de los fragmentos. (Camayd-Freixas, 1998, p.94)

Finalmente, o crítico Franco Moretti (1996) também propõe uma interpretação para o realismo mágico, contudo, diferente dos demais, considera-o como uma espécie de ponto de chegada da tradição da épica moderna. Com essa formulação o crítico busca explicar a aparente anomalia de "textos sagrados" da modernidade, como Fausto, de Goethe, Ulysses, de Joyce, e Cem anos de solidão, de García Márquez. Segundo o autor, se na épica clássica o mundo do herói e suas ações compõem um sentido de totalidade, no caso das obras mencionadas, épicas modernas, ao contrário, os feitos do herói respondem apenas a um plano individual, correspondente à era do capitalismo moderno. Para resolver o impasse de representar um mundo moderno por uma forma antiga, Goethe teria recorrido, no segundo volume de Fausto, à alegoria. Para Moretti (1996, p.78), a alegoria é a "poética da modernidade", mais precisamente, da 
modernidade capitalista. Assim, Fausto, como epopeia moderna, retoma uma forma clássica da antiguidade, modificando-a pela alegoria, para representar a ascendência do moderno capitalismo europeu. O sentido alegórico permite que, retornando a um passado mítico, se apresente um mundo em processo de modernização e reificação. $\mathrm{O}$ mito fáustico, desse modo, corresponde ao mito da modernização, da criação de um mundo moderno em substituição a outro arcaico. ${ }^{11}$

No entanto, quando a épica moderna se desenvolve fora do contexto europeu, originário do capitalismo, a narrativa adquire outros sentidos e se constrói por meio de outras técnicas. É nessa "(re)reformulação" da épica que o crítico situa a ficção do realismo mágico. Para explicá-lo, Moretti menciona Grande sertão: veredas, mas trabalha prioritariamente com o paradigmático Cem anos de solidão, afirmando que, com essa obra, pela primeira vez na história da literatura ocidental, o centro de gravidade do sistema literário deslocou-se da Europa para a América Latina.

Segundo o crítico, o processo de modernização do continente latino-americano provocou também, como no europeu, um retorno do mito à literatura. Porém, diferente da Europa, a modernização na América Latina se deu de forma traumática, forçada e contraditória, o que levou a novos resultados na incorporação do mito. Assim, enquanto o Fausto de Goethe apresenta uma transição completa para a modernidade, o mito fáustico na literatura latino-americana evidencia uma modernização inacabada, problemática e paradoxal. Desse modo, ao mesmo tempo em que o pensamento mítico é revitalizado pelos estímulos da modernização, surge, na ficção do realismo mágico, como uma forma de a ela se opor. Cem anos de solidão, demonstra o crítico (Moretti, 1996, p.243), conta a história de uma "incorporação": a de uma isolada comunidade que é arrebatada

11 Franco Moretti (1996) discute o mito fáustico na mesma perspectiva proposta por Marshall Berman (1986, p.41), para quem "O Fausto de Goethe é a primeira e ainda a melhor tragédia do desenvolvimento”. Moretti também recontextualiza, no âmbito do realismo mágico, a ideia de Berman (1986, p.43) de que a figura do Fausto goethiano adquire ressonância especial em países social, econômica e politicamente subdesenvolvidos. 
pelo sistema mundial moderno, o qual a sujeita a uma aceleração inesperada e extremamente violenta. Combinando inventividade formal e preocupação política, narrativas como essa tomam vários aspectos da transformação social para reescrevê-los como fenômenos mágicos ou como o retorno de arquétipos antigos. Nesse aspecto residiria, explica Moretti, o sentido político e o caráter de resistência do realismo mágico.

Como é possível observar, unindo essas proposições de diferentes nuances encontra-se uma associação frequente entre os processos de modernização das regiões periféricas e a incorporação de uma dimensão mítica pelas literaturas delas provenientes. Essas reflexões corroboram, por esse aspecto, as proposições de Ángel Rama e Antonio Candido, críticos que trouxeram a questão para o plano da literatura latino-americana, discutindo-a em vista da tradição dos romances de feição regionalista. Diante disso, como último movimento de leitura do romance de José Cândido, serão feitas, a seguir, algumas considerações acerca do modo específico como a modernização e o mito se articulam na narrativa, gerando a cosmovisão apresentada no início deste capítulo. Para tanto, serão observados, principalmente, os conflitos culturais que decorrem do trânsito do herói por dois universos distintos, mas ambos subdesenvolvidos e afetados pelo influxo modernizador.

\section{Um lobisomem entre o sertão e a cidade: modernização, mito e identidade}

Eu acho que deviam passar um trator por cima da civilização - um trator, para ver se nascia outra nova - porque esta que está aí, não dá mesmo.

José Cândido de Carvalho (2004, p.117)

O romance $O$ coronel e o lobisomem é uma narrativa da modernização nas veredas da literatura regionalista brasileira. $\mathrm{O}$ coronel Ponciano é uma personagem presa ao passado e à origem campesina, 
mas que se vê diante do inexorável avanço da modernidade e da urbanização. Criado inicialmente pelo avô Simeão nas terras do Sobradinho, uma propriedade rural do pequeno distrito de Santo Amaro, localizado a 40 quilômetros da cidade de Campos dos Goytacazes, no norte fluminense, que fica, por sua vez, a quase 300 quilômetros da capital do estado, Ponciano passa a morar, ainda menino, em região mais afastada, onde vive a supersticiosa prima Sinhá Azeredo. A descrição do cenário confirma o isolamento da área, revelado já em seu nome: "nação de chuva - um oco de coruja chamado Sossego, onde só dava presença bicho penado. De noite, era aquela algazarra de lobisomem, pio de coruja, asa de caburé, fora outros atrasos dos ermos" (Carvalho, 1983, p.3-4). Diante desses espaços em que transita o protagonista, compreende-se que mesmo sendo uma literatura produzida no Sudeste do país, pode-se seguramente falar em "regionalismo", no sentido de uma tradição de narrativas que tematizam a vida e os problemas de áreas rurais, interioranas, afastadas dos grandes centros. Não se trata de uma paisagem-moldura dos acontecimentos, já que esse espaço é fundamental à natureza dos conflitos que movem o enredo.

Na continuação, Ponciano, menino branco, ruivo (a barba será cor-de-fogo), neto de um poderoso proprietário de terras, acaba sendo expulso do Sossego, ao ser flagrado no campo "em delito de sem-vergonhismo" com uma "pardavasquinha", ou seja, uma menina mulata. A prima beata o acompanha para a nova morada, uma chácara na Rua da Jaca, na cidade de Campos dos Goitacazes, onde ele deveria agora estudar. $\mathrm{O}$ narrador lembra da viagem de trem e das primeiras impressões do menino que deixa os "ermos" e descobre o ritmo da cidade: "[...] já a cidade apresentava suas casas e um povinho apressado corria no debaixo dos guarda-chuvas" (Carvalho, 1983, p.5). Ali Ponciano permanece até a morte de Simeão, momento em que assume o comando do Sobradinho. Representações das áreas rurais da região, sob uma perspectiva reveladora do atraso, da rusticidade e do isolamento é o que não faltam por toda a narrativa: "sem-fim dos pastos" (Carvalho, 1983, p.5), "confins" (p.6), "escondido tão distanciado", "terra mais de bugre", "bicho-do-mato, 
sem nenhuma aptidão para a cortesia” (p.7), "fundo do sertão restinguento” (p.8), "nação de boi”, "os lonjais” (p.15), "os ermos” (p.30), "pasto é lugar de lobisomem” (p.48) etc.

Já a cidade que vai aparecendo nas idas espaçadas de Ponciano a Campos é o lugar dos cafés, das casas de jogos, dos "palcos" dos cabarés, dos prostíbulos, onde, enfim, passava seus momentos de lazer e libertinagem na companhia dos amigos. Esse ambiente urbano é perpassado por algumas referências à cultura francesa, reflexos do clima de Belle Époque que chegavam da capital ao interior: "O major [...] chamava minha atenção para um Moulin Rouge chegado do Rio, bem aparelhado de rabo de saia. Por baixo dos nomes das damas, o major fez correr o lápis. Era uma estrangeirada de Zuzus e Mimis de não ter fim" (Carvalho, 1983, p.170). São esses os dois movimentos que Rama visualiza no processo de transculturação: um impacto que vem de países estrangeiros influentes e atinge as capitais e grandes centros dos países periféricos (no caso, da França ao Rio de Janeiro), e outro que ocorre dessas capitais para as regiões interioranas (do Rio de Janeiro para Campos dos Goytacazes).

Datas precisas não aparecem na narrativa, no entanto, há elementos que permitem situar o curso dos fatos entre meados do século XIX e primeiras décadas do século XX: a referência mais específica é a menção ao "Teatro São Salvador" (Carvalho, 1983, p.189) da cidade de Campos, fundado em 1845 e demolido em 1919, que aparece também no primeiro romance do autor; além desse índice, há a referência à Guarda Nacional, fundada em 1831, reformada duas vezes, uma em 1852 e a outra em 1873, e extinta em 1922. Assim, seria percorrendo esse período aproximado de tempo que Ponciano teria chegado quase "na beira dos sessenta" anos de idade (p.301). Época de transformações políticas, econômicas e sociais intensas, marcada pela transição do país da Monarquia à República, além das espacialidades diferentes, convivem no romance uma dupla temporalidade: os resquícios de um passado colonial não superado, que mantém o poder agrário (o latifúndio e o escravismo), convivem com o anúncio de futuro republicano que acena para a modernidade (a abolição da escravatura, a urbanização, a industrialização e a democracia). 
Esses espaços perpassados por uma dupla temporalidade marcam, então, o trânsito do protagonista entre dois mundos, duas culturas, dois universos de valores: o sertão rústico arcaico e a cidade civilizada em ritmo de modernização. Ponciano começa a estender suas estadias na cidade, que de poucos dias passam a durar gradativamente uma semana, uma quinzena, um mês todo. A presença de Ponciano na cidade, motivada inicialmente pela diversão, intensifica-se depois que começa a frequentar a casa de seu advogado e amigo de vida noturna, Pernambuco Nogueira. É por conta da beleza e da exagerada simpatia de D. Esmeraldina, esposa de Nogueira, que a cidade se torna tão atrativa para Ponciano, a ponto de abandonar o campo. A mulher no romance de José Cândido possui um poder nefasto. O coronel passa a almoçar todos os domingos na companhia do casal e, tendo fracassado em várias tentativas de relacionamento amoroso, se vê agora enfeitiçado pelos encantos da moça. Interessante é notar o jogo de sedução dessa Sofia machadiana: Esmeraldina logo reconhece o poder de seu fascínio sobre Ponciano e utiliza-o a seu favor. Diferente das outras mulheres com quem Ponciano tentara se casar, a Sra. Nogueira demonstra interesse pelas histórias mirabolantes do coronel, como o caso da onça, procura agradá-lo com os pratos que serve, leva-o pela mão para conhecer os cômodos da casa enquanto o marido dorme; em síntese, insinua-se, como pode, sem, no entanto, comprometer-se. O coronel, por sua vez, não se aproveita da aparente liberdade concedida, mas se apaixona perdidamente e deixa isso transparecer.

Esmeraldina é o motor da ruína de Ponciano. Ela, mulher da cidade, educada sob os padrões de comportamento de uma modernidade incipiente, procurava seus referenciais de cultura na capital francesa. Ele, homem do campo, rústico, integrante do mundo agrário do sertão, com valores e comportamentos pautados na figura de seu avô, imagem síntese de um passado de esplendor da sociedade patriarcal, baseada no mandonismo, no poderio dos grandes latifundiários; seu imaginário e o da comunidade a que pertence é povoado por lendas, crendices, superstições; seus assuntos e sua linguagem evocam os elementos do meio agrário. Fingindo estudar no tempo 
em que esteve na cidade, Ponciano pouco absorveu os códigos de comportamento e as ferramentas que garantiriam o exercício do poder no ambiente urbano. Apesar do pouco domínio mesmo sobre as rotinas do campo, é com esse ambiente que se identifica, pois nele sua função de coronel possui utilidade: os moradores da região, agregados, parentes, vizinhos recorrem a ele quando precisam resolver algum problema, de modo que seu papel é o de instaurar a ordem e a proteção aos mais fracos e desprotegidos. Na cidade, no entanto, sua patente de coronel é inútil e não lhe garante uma posição de respeito ou influência. Os símbolos de poder do coronel não têm efeito na cidade.

Ponciano entende, a seu modo, a distância cultural que o separa de Esmeraldina. Quando a conhece, encantado por seus modos e sua beleza, o coronel logo pensa nas vantagens dos homens formados, como Nogueira, sobre os demais, no momento de escolher uma mulher para tomar como esposa. Ponciano também demonstra a consciência dessa distância ao selecionar as aventuras que decide contar à moça: "Estive quase conta-não-conta o caso da sereia das águas, o que não fiz por achar que peripécias dos areais não calhava em recinto tão educado" (Carvalho, 1983, p.113). Percebe-se, nessas passagens, a dupla mentalidade, ora mítica, ora racional, de que fala Spindler (1993). Esse choque cultural que se mostra revelador das limitações de Ponciano ocorreu também em relação a outras mulheres de quem tentara se aproximar, configurando-se, como apontou Zilberman (1977), em um impedimento de seu acesso ao universo das mulheres ligadas ao meio urbano. A tentativa de conquistar Isabel Pimenta, professora, "mestra de letras", mostra-se ainda mais desastrosa em função do abismo intelectual que os separa. Na situação, o coronel não encontra respaldo em seu repertório de conhecimentos e histórias fantasiosas do campo, que se revelam ineficazes diante dos interesses e das convicções da mulher que busca impressionar. A cena, que é exemplar do choque cultural observado por Ángel Rama (2004) nas narrativas da transculturação, adquire contornos cômicos (e ao mesmo tempo trágicos), em decorrência do visível embaraço e desajuste do coronel ao tentar cortejar a moça: 
Nos rodados da menina Isabel meu atrevimento encolhia. A boca do coronel, dona de tanta fala, nessas especiais circunstâncias perdia os venenos. Lá uma vez ou outra, mesmo assim em feitio medroso, saía uma inquirição desavergonhada:

- Vossa Mercê já foi mordida de cobra?

A moça ria desses e outros despautérios, que outra coisa não podia fazer. Uma noite, estando em gozo de cadeira de balanço, no alpendre, um vagalume acendeu e apagou a brasa do rabo bem junto dela. Logo aproveitei para soltar bobagem:

- Dona Isabel já viu a pessoa de um boitatá?

Não viu, nem acreditava em invencionices do povo bronco dos ermos. Pois eu, em vez de meter o boitatá no saco, ainda tive o desplante de apresentar aos olhos de água da moça, todo apetrechado e desbatizado, um lobisomem que conheci em dias recuados da infância:

- A menina nem pode fazer ideia. Um monstrão.

A mestra de letras, no vaivém da cadeira de balanço, aturou tudo dentro dos bons ensinamentos da educação. A certa altura, eu mesmo achei que era lobisomem demais. Mudei a toada, falei do tempo:

- Vai cair água. O sul está puxando.

Só isso é que saía da minha ideia, bobajada, tolice de pegador de rês. (Carvalho, 1983, p.71)

Essa consciência que aflora em Ponciano é, no entanto, pouco duradoura. Logo que se vê na ausência de Isabel, desconsidera a distância cultural que os separa e tenta se convencer de que seu acanhamento não se justifica. Para tanto, procura consolo na imagem que faz de si como homem de sucesso nos prostíbulos, sem levar em conta a completa diferença entre as situações.

Depois, apaixonado por Esmeraldina, Ponciano tenta se adaptar à imagem que acredita ser a de um homem por quem ela se interessaria. Assim, por ela, o coronel dos pastos torna-se um entusiasta da modernização: a seu pedido, manda fazer ternos novos e, a partir disso, tenta incorporar hábitos cosmopolitas. Para agradá-la, sem perceber que está sendo manipulado e seduzido, com tudo consente: 
"Balançando a cabeça, como boi de presépio, eu concordava com tudo" (Carvalho, 1983, p.189). Entre as gentilezas de Ponciano, leva o casal de carruagem ao teatro e assiste a representações sacras; presenteia-a com joias caras e outros mimos; e empresta dinheiro a Nogueira, sem burocracias, como a um amigo de confiança. Hospedado no Hotel das Famílias, assusta-se com a percepção da passagem do tempo na cidade: "Mês de cidade tem mil pés, corre ligeiro, de parelha com o vento. Quando dei por mim, um ano havia morrido e outro entrava na folhinha [...]" (Carvalho, 1983, p.195).

Nessa altura, Ponciano ainda é um homem de posses, mas a estrutura que o levará ao fracasso financeiro começa a se constituir, tendo como base sua submissão a Esmeraldina: Pernambuco Nogueira, auxiliado pelos encantos de sua mulher que lhe servia de isca, conseguia tudo o que queria do coronel. Um risco, no entanto, surge em seu caminho de êxito pela extorsão. Envolvendo-se em especulações comerciais, Ponciano estabelece sociedade com João Fonseca, homem humilde, cauteloso e honesto que, justamente por essas qualidades, não gostava do ardiloso Nogueira. Sentindo-se ameaçado por essa parceria, Nogueira procura meios de desfazê-la. Para isso, serve-se de Fontainha, rapaz que causa intriga entre Ponciano e Fonseca, convencendo o coronel de que o sócio só lhe prejudicava, atravancando seus ganhos que poderiam ser muito superiores aos atuais. A verdade é que Fonseca era homem prudente e que conhecia o terreno oscilante das negociações, motivo porque agia com cautela, arriscando-se pouco. Desfeita a sociedade com Fonseca, Ponciano permite que Fontainha fique como responsável por cuidar dos seus negócios, agora administrados em um escritório que monta na cidade. A decoração do lugar fica por conta do novo secretário, que não poupa luxo e ostentação, valendo-se do dinheiro do coronel. Ponciano, inebriando-se com os ares de requinte e sofisticação de sua nova vida urbana como homem de negócios comerciais, além de afastar-se definitivamente de suas terras, procura também evitar que o mundo do sertão o encontre na cidade e o lembre de suas origens: "Para evitar focinho do meu povo na cidade, dei carta branca a Juquinha Quintanilha: - O que o compadre escrever eu assino em 
cruz" (Carvalho, 1983, p.204). E, desse modo, passou a delegar suas responsabilidades de proprietário.

Enquanto as terras de Mata-Cavalo estiveram sob os cuidados de Juquinha, Ponciano esteve tranquilo, pois o rapaz administrava a propriedade melhor do que ele o faria. O problema é que o bom peão adoeceu e, assim como ocorreu com Fonseca, Ponciano deixa de contar com ajuda de mais uma pessoa de sua confiança. Ressalte-se que Ponciano, coronel que cumpre a missão de proteger, se compadece pela situação do amigo, interna-o, passa noites à cabeceira da cama do doente no hospital e, por fim, faz questão de dispensá-lo dos serviços do campo, em vista de uma recomendação médica. Com as economias que possuía e ajuda financeira do coronel, Juquinha compra então um pedaço de terra, para onde muda-se com sua família.

Aproveitando-se da situação, o casal Nogueira sugere a Ponciano que coloque um primo de Esmeraldina no comando da propriedade de Mata-Cavalo, o jovem e arrogante engenheiro Baltasar da Cunha. Ponciano aceita, já que "Dona Esmeraldina não pede, Dona Esmeraldina manda" (Carvalho, 1983, p.218). Outro conflito cultural novamente se impõe, pois, afrontado desde o princípio pelos modos do rapaz, o coronel reconhece que ele não tem perfil para assumir a administração do campo: "Que ia dizer o povo da ventania sabendo no mando de Mata-Cavalo um sujeitinho tão engomado e lustrado?" (p.219). No entanto, engana-se achando que o engenheiro, "pessoa desnascida para a labuta de curral”, desistiria da empreitada quando percebesse sua inaptidão: "[...] ri sozinho ao figurar os desmandos que o ventão dos ermos ia fazer na cabeleira encaracolada do sujeitinho. No primeiro safanão do inverno, o primo Baltasar saltava mais desinfeliz que perereca em pata de boi” (p.219). Ao contrário, protegido pelo parentesco com Esmeraldina, o engenheiro acomoda-se bem a uma rotina de exigir valores elevados de Ponciano, sob a justificativa de estar promovendo bem-feitorias na propriedade.

Estrutura de degradação alicerçada no afastamento das pessoas honestas e na aproximação das oportunistas, Ponciano entrega-se cada vez mais às manipulações que o demovem a aderir à modernização. Acreditando na falsa promessa de Esmeraldina de passar 
alguns dias em Mata-Cavalo, o coronel confere total liberdade a Baltasar para investir no término da reforma da propriedade, utilizando tudo o que houvesse de melhor, sem importar o preço. A orientação é para que o engenheiro embeleze o lugar. Dessa situação surge uma cena das mais emblemáticas do embate cultural representado na narrativa, pelo choque entre uma perspectiva urbana e outra sertaneja do que seria o "belo". O olhar do coronel do sertão não consegue assimilar objetos culturais da civilização burguesa moderna que o engenheiro toma como necessários à decoração do ambiente. Qual seria a reação de um homem rústico diante de uma pintura artística como ornamentação? José Cândido, assumindo a cosmovisão do homem do campo, explora o conflito que uma situação como essa poderia render:

Não sabia mariquice mais que inventar e até quadro de parede, uma peça de metro e meio, comprou para guarnecer a sala da herança. Não sendo eu entendido nas artes da borração, pouco apreciei o tingido que representava um lacrimal onde um par de gansos, retorcidos de pescoço, refrescavam seus por-baixos no azulinho da água, enquanto certa moça de cabelo empolvilhado, num banco de jardim, abanava o leque na companheiragem de um galante enfeitadinho de rendas e penduricalhos. A dama parecia estar dentro de um repolho, tão grande era o avantajado dos seus panos. Olhei e não gostei:

- Muita roupa, muita roupa. (Carvalho, 1983, p.225)

Essa passagem deixa transparecer um olhar subversivo ao pensamento artístico burguês e explicita o relativismo do conceito, culturalmente construído, do que seja o belo. Aceitando o que sugeriu Ianni (1991) ao delinear as tendências das obras do realismo mágico, a cena do romance pode ser entendida como uma subversão de uma categoria corrente do pensamento artístico, pois apresenta um olhar paródico sobre as convenções do mundo burguês civilizado. Não bastasse essas ponderações que Ponciano realiza individualmente, "de Ponciano para Ponciano", como diria, o leitor ainda se depara com uma espécie de confraria cômica de críticos desautorizados, 
avaliadores de arte, sendo eles, o tabelião Pergentino de Araújo e Pernambuco Nogueira. Apesar dos pareceres não serem nada técnicos, a avaliação de Ponciano, homem do campo, é a que provoca perplexidade nos amigos citadinos, pois expõe sua vivência rural e a falta de domínio dos códigos urbanos:

Por ser de fino lavor, a obra ficou no escritório aguardando condução segura, do que aproveitou Pergentino de Araújo para vistoriar a compra. Com ele, veio Pernambuco Nogueira, interessado em aquilatar o gosto do primo. Franqueei a peça. Pergentino e Nogueira miraram e remiraram os seus pormenores. $\mathrm{O}$ aposentado da Justiça ficou mais cativo do anilado do céu:

- É vistoso, calha bem.

Nogueira disse que não, que bonita era a dama:

- Veja o porte, veja o afunilado da cintura!

A pedido deles, dei meu parecer. De modo a não descontentar nem um, nem outro, retorci a resposta para o lado mulherista. $O$ libertino que fosse trabalhar dama assim, tão vestida e revestida, ia perder mais de hora no descascamento dela:

- É roupa demais, seu compadre. Tem jeito de armarinho.

Nogueira mirou Pergentino espantado. E em seguimento, como um possesso, largou gargalhada estrondosa, a ponto do charuto escapulir do beiço e rolar no tapete. (Carvalho, 1983, p.225)

Tentando integrar definitivamente a classe burguesa, Ponciano é estimulado por Fontainha a deixar o Hotel das Famílias e morar em lugar mais luxuoso, que fosse condizente com a importância de sua figura: deslumbrado pelos requintes da europeização imaginária da cidade, o coronel dos pastos passa agora a morar no "Hotel dos Estrangeiros" - nome sugestivo de sua não pertença ao espaço urbano. Apesar de todo o esforço de adaptação a esse mundo de novos códigos, o coronel fracassa na tentativa de se modernizar pelo vestuário, pelos ambientes que ocupa, pelos costumes a que adere: sua figura em transformação, na verdade, representa o jogo de aparências da modernidade ao entrar na periferia do capitalismo. 
O coronel Ponciano, estrangeiro na cidade, não consegue dominar a lógica e os valores desse mundo que para ele é novo. Como coronel de um mundo arcaico, onde as relações seguem uma lógica quase feudal, pois lá protegia seus agregados enquanto obtinha deles em troca respeito e lealdade, Ponciano se depara agora com um mundo regido por outras leis de funcionamento. De uma cosmovisão pautada nas trocas de favores, Ponciano ingressa nas negociações de compra e venda de mercadoria, no mercado financeiro e impessoal dos bancos, em suma, em um mundo capitalista em que todas as relações são reificadas. Seus códigos de convivência e os símbolos de poder em que acredita estão defasados para o ambiente urbano, mas o coronel não percebe isso, então continua a valorizar elementos que supõe garantir-lhe o respeito das pessoas, como o tamanho de sua barba, a altura de sua voz e sua força física. Acreditando nas amizades e na palavra dos que tinha por amigos, o coronel não compreende a traição que sofre por aqueles que o cercavam, pessoas nas quais depositava confiança.

Ponciano trilha o caminho da falência financeira. Fontainha se une a Baltasar da Cunha e, juntos, os dois tiram o que podem do coronel, sob o argumento de que se ele tivesse algo a reclamar, que o fosse dizer ao Dr. Nogueira ou a D. Esmeraldina. Ponciano, temeroso de magoar os sentimentos da moça e perder a amizade do casal, aguenta todos os desaforos imagináveis dos funcionários. Além disso, tem vários gastos com a campanha política de Nogueira. A extorsão de Baltasar alegando investimentos em Mata-Cavalo não cessa e, como Esmeraldina sugere que passaria uns dias de descanso no Sobradinho, o coronel, tolo, acreditando novamente na promessa, começa a despender dinheiro também para a modernização da casa que era de seu avô. Não bastasse isso, ainda arca com custos de decoração para a casa do casal Nogueira e presenteia Esmeraldina com joias cada vez mais caras. Mas a cartada final ainda estava por vir.

Já fazendo empréstimos, mas esbanjando poder, decide fazer um investimento que o levará à ruína definitiva: compra toda uma safra da produção de um usineiro falido. Fonseca, que apesar de desfeita a sociedade, ainda estimava o coronel, alerta-o da loucura da manobra 
e o aconselha a se desfazer da safra mesmo que a preço baixíssimo para não se ver em mais prejuízos. $\mathrm{O}$ coronel não lhe dá ouvidos e é surpreendido, sem demora, por uma queda no preço do açúcar nunca antes vista: "Um vento de urubu varreu a Rua do Rosário, de quebrar no meio negociante forte, gente de créditos até na praça do Rio. Da noite para o dia, vi escorrer, como melado em cuia furada, os meus ganhos todos. Dei de ombros: - Dinheiro vai, dinheiro vem" (Carvalho, 1983, p.263). Todavia, o movimento do dinheiro de Ponciano só foi de ida. Devendo aos bancos e já recebendo as cartas de cobrança, Ponciano vai tirar satisfação com os bancários, que muito bem o tratavam enquanto ele era rico e podia investir. Ponciano, ingenuamente, toma como ingratidão a pressa do banco em receber, sabendo que, cliente há tantos anos, sofrera com o abalo do mercado do açúcar: "Cocei o queixo, pedi novos prazos, o que não era favor, em vista dos bons lucros que eu tinha carreado para as burras dos capitalistas" (Carvalho, 1983, p.265). Dito isso, teve de escutar que "[...] banco era casa de lucro e não sociedade de favoritismo" (p.265). Essa sentença contém a verdade da distância que separa a natureza das negociações a que Ponciano estava habituado das novas relações impostas pelo capitalismo. Ponciano foi mais um "coronel da roça" que o mercado financeiro dos créditos levou à derrocada.

E quanto mais acentua-se a decadência financeira do coronel, mais ele tenta negá-la por demonstrações de esbanjamento e luxo. Chega a rasgar dinheiro na frente das pessoas, pelo o que o tomam por louco. O resultado é que perde seus bens para cobrir as dívidas com os bancos: se vão Mata-Cavalo, em que tanto gastara, e o escritório da cidade, com todos os objetos de valor. Falido, Ponciano passa a ser desprezado por Nogueira, ingratidão que o atordoa. $\mathrm{O}$ engenheiro de Mata-Cavalo diz que levará Ponciano na justiça pelos atrasados e Nogueira dá de ombros. Esmeraldina viaja sem deixar notícias para o Rio de Janeiro e Ponciano descobre que ela traía o marido com Selatiel, ainda assim resistindo em acreditar. Fontainha e Baltasar fazem chacota de Ponciano e as pessoas da cidade o veem apenas como um homem falido, a quem não se deve respeitar. A narrativa, no entanto, não é maniqueísta a ponto de ser possível 
generalizar que o ambiente urbano, como um todo, se reduz à corrupção e ao interesse financeiro. No momento da falência, Ponciano ainda encontra algumas poucas pessoas boas que o ajudam. Além de Fonseca, que fez o que pôde para alertá-lo, Ponciano recebe a ajuda de Carqueja, um advogado pobre e honesto, grato por favores que recebera do coronel em um tempo distante. Carqueja compra a causa de Ponciano e trata de defendê-lo dos ataques de Baltasar nos tribunais. Mesmo ganhando a causa, o advogado não aceita receber pagamento do coronel, ficando apenas com o estritamente necessário para cobrir os gastos do trâmite. Diante disso, Ponciano faz um balanço do que, de fato, considera pessoas de valor e importância:

Não houve modos de receber um tostão. Todo maltratado, casaco roído na curva do cotovelo, gravata de cor perdida desde anos, Serafim Carqueja tinha ares de rei. Que eu guardasse as economias e deixasse em seu poder a amizade:

- É o que basta, é o que basta.

O mulato valia ouro em pó. Nunca que um Pernambuco Nogueira, mesmo ajudado pelo governo, mesmo de anelão no dedo, chegava às alturas dele. Era até uma falta de respeito medir no mesmo metro um e outro. Nogueira, diante da grandeza do encaminhador de papéis, ficava diminuído, menor que um rato. Virava sujeito merecedor de penas e dós, um pobre-diabo:

- Desimportante. (Carvalho, 1983, p.281)

O dinheiro, no entanto, era pouco, e Ponciano não permanece com ele por muito tempo: diante do falecimento de Fonseca, gasta-o garantindo um enterro luxuoso ao amigo. Como forma de agradecer, a viúva de Fonseca presenteia-lhe com um sabiá-laranjeira, agora a única riqueza de Ponciano: "No mais, não era de bolso vazio quem possuía um passarinho como o que herdei [...]. Muitas outras gentes tinham baús de brilhantes e brilhantins, mas cantoria de veludo só quem tinha mesmo era o coronel Ponciano, na gargantinha do seu sabiá-laranjeira" (Carvalho, 1983, p.291). As alianças que carregava consigo para caso conseguisse finalmente se casar são o último 
objeto de valor de que o coronel se desfaz. Assim, o final do livro é de uma tristeza comovente.

Juquinha, ex-empregado que agora ironicamente abriga o coronel, descobre que pessoas do governo pretendem levantar todas as dívidas de impostos não recolhidos por Ponciano, desde o princípio. Juquinha e a esposa, que sempre foram muito gratos à generosidade do ex-patrão, ficam arrasados com a notícia - ela chega a chorar junto do marido -, preocupando-se mais até do que o próprio procurado, que parece não dar o braço a torcer e se admitir derrotado. Louco, pois, a essa altura, cada vez mais seus rompantes vinham à tona, como se estivesse nos pastos, Ponciano, que já causara alvoroço na cidade, arrumando brigas, xingando as pessoas, acaba deixando também a casa de Juquinha para poder se esconder do ataque do governo no Sobradinho. Falando e gritando sozinho no trem que o levaria a Santo Amaro, as pessoas se assustavam com sua aparência. Três anos de cidade serviram para acabar com a figura de Ponciano e, agora, o lobisomem, o ser transformado e amaldiçoado é ele próprio: "Providenciei pular do trem. [...] Da janela, cara de fora, barba ao vento, eu devia ser a figuração de Satanás [...]” (Carvalho, 1983, p.293). Atordoado, chega gritando no Sobradinho, como se fosse encontrar a casa habitada. Porém, só há ruínas do que um dia foi o império de Simeão. Os únicos que aparecem no Sobradinho, depois de ouvirem os gritos de Ponciano, são três de seus ex-empregados e amigos dos arredores, que ficam espantados, quase sem nem reconhecer o coronel. Ponciano os cumprimenta e, delirando, diz ainda que irá modernizar o casarão, que ficará irreconhecível, e até quadro na parede mandará colocar. O entusiasmo se converte em desespero quando imagina ver homens do governo na porteira de suas terras. Os campeiros tentam tranquilizá-lo, dizendo que não há nada, mas, alucinado, Ponciano tem um ataque enquanto corria para buscar as armas com que iria se defender de seus inimigos imaginários.

É a partir disso que se dá a narração de sua morte: fala das pessoas falecidas que encontra, fica sem entender porque se sente tão disposto como se moço fosse e, sabendo que o diabo anda causando sofrimentos aos seus conhecidos, sai em seu encalço para a grande 
batalha. Ao final dessa narrativa da modernização, o coronel Ponciano, transformado no herói que sempre acreditara ser, vê-se acima do mundo terreno dos bens materiais, rumo à salvação da humanidade, à realização de um feito realmente superior: "Em pata de nuvem, mais por cima dos arvoredos do que um passarinho, comecei a galopar. Embaixo da sela passavam os banhados, os currais, tudo que não tinha mais serventia para quem ia travar luta mortal contra o pai de todas as maldades" (Carvalho, 1983, p.304). Compreende-se, então, o locus insólito de enunciação de onde surge a voz do narrador que afirma no início do livro: "Já morreu o antigamente em que Ponciano mandava saber nos ermos se havia um caso de lobisomem a sanar ou pronta justiça a ministrar" (Carvalho, 1983, p.3). Fechando-se a dimensão mítica, compreende-se que não é na cidade que está agora o coronel, tampouco nos pastos: está em uma realidade sobrenatural do além-morte, resolvendo, como herói que é, os grandes problemas do mundo, e não mais as mesquinharias humanas, ocupações para homens pequenos de espírito.

Essa segunda parte do romance, de maior unidade e crescente tensão, correspondente à presença do coronel na cidade, costuma ser um tanto ignorada pelas análises, perdendo em atenção para as narrativas extraordinárias do coronel no sertão. Com isso, acaba-se esquecendo que o romance de José Cândido narra, sobretudo, o processo de degradação de um homem grandioso que, justamente por essa virtude, não se adaptou ao avanço cruel da modernidade. Éa modernização contraditória de um país periférico que leva Ponciano à falência.

O conflito de Ponciano com o governo é bastante significativo de uma estrutura perversa do capitalismo que se volta àqueles que movimentam suas engrenagens. Ponciano foi um oficial superior da Guarda Nacional, ou seja, representou uma das instâncias de poder de seu país - assim como sua versão em major da crônica. A centralização da Guarda Nacional, que ocorre em meados de 1850, já foi um procedimento tomado visando a reformulação das estruturas nacionais, assim, Ponciano tem um posto que é decorrente de um período de modernização. No entanto, essa modernização se 
baseia em uma obsolescência programada, cada vez mais acelerada nos países periféricos: Ponciano, que pensa ser um fomentador da modernização, é apenas uma peça da engrenagem, e, por isso, como um produto reificado, será descartado quando preciso. Ao invés de promotor da reificação, Ponciano é também o produto dela. Ainda que seja associado a um órgão do Estado, sua função já se cumpriu, e ele pode ser descartado. A consequência disso é que mesmo como representante de uma elite, a elite agrária do país, Ponciano não se vê protegido pelo Estado, sendo, ao contrário, por ele perseguido.

Esse conflito remete a outra narrativa da literatura latino-americana de meados do século: El coronel no tiene quien le escriba, do colombiano Gabriel García Márquez (2012). Escrita em 1957, mas publicada em 1961, a novela conta a história dramática de um coronel já bastante debilitado e pobre, que aguarda ansiosamente a chegada de uma carta que trará a notícia de sua prometida aposentadoria. Apesar de ter cumprido com seu papel, servindo ao governo, o coronel passa anos de miséria, agonizando com sua esposa, também doente, e procurando modos de, ao menos, se alimentarem. Para isso, vendem tudo o que têm e começam a sobreviver de doações de conhecidos. Pela relativa semelhança entre as realidades rurais pobres da América Latina, o ambiente está permeado por elementos encontrados no romance de José Cândido. Além da semelhança mais notória, pelo posto dos protagonistas, o coronel da novela também possui um galo de rinha, que inclusive se vê a ponto de doar, por não ter condições de alimentá-lo. Essa narrativa, apesar de bastante contida em relação aos eventos mágicos de Cem anos de solidão, apresenta também uma atmosfera sobrenatural relacionada ao imaginário das personagens, que acreditam na existência de fantasmas. Em suma, trata-se de outra narrativa latino-americana em que, como ocorre em $O$ coronel e o lobisomem, o maior perigo para as personagens não está em uma realidade extraordinária de fantasmas e monstros, mas na própria vida real, na própria estrutura social a qual estão sujeitos. 


\section{Considerações finaIS}

Espera-se ter demonstrado que o romance $O$ coronel e o lobisomem, de José Cândido de Carvalho, ao contrário do que, talvez, aparente, não figura como obra isolada na produção de seu autor e tampouco no panorama da literatura brasileira da época. Em suas demais criações, José Cândido também verteu um olhar crítico e paródico à sociedade, rindo da altivez ingênua, dos modos aristocráticos, dos jogos de aparência e interesse, expondo ao ridículo as vaidades humanas, sobretudo as vaidades humanas de um país periférico. Porém, o escritor também é sensível a esses dramas e se compadece daqueles que, como Ponciano, apesar dos ares de superioridade, são pequenos e frágeis diante das engrenagens que os oprimem. A atividade jornalística de José Cândido o aproximou, certamente, da realidade visível do país. Entretanto, no momento de devolvê-la ficcionalmente, seja em suas crônicas, contos, biografias, romances, o escritor não se contentou com o facilmente apreensível, preferindo descer até níveis mais profundos e complexos, facetas recônditas de uma realidade incômoda, cruel, que ele apresenta sob as máscaras do riso e do sobrenatural. Ou seja, àquilo que é sério, responde com o riso; ao que é real, com o sobrenatural.

Herdeiro do modernismo, sua escrita alcança o equilíbrio estético ao dosar, com naturalidade e harmonia, a tradição da fala popular 
e as técnicas da escrita moderna. A espontaneidade do estilo, no entanto, não corresponde, como se viu, à facilidade para escrever, ao contrário, a ficção era o seu carregar pedras sem fim. Exigente consigo mesmo, queria o tom certo para colocar na voz de cada narrador. Não bastava criar personagens. Tanta vida nelas deposita que suas figuras só faltam saltar do livro. Os movimentos, os gestos, a "voz" do coronel, sua sintaxe, seu vocabulário, seu ritmo, fixam-se no imaginário do leitor e o tornam uma figura inesquecível.

Admirador confesso de Lins do Rego, ainda que não o fosse, seu romance de 1939 o revelaria. Mas, mais que seguir suas referências, José Cândido abriu caminhos próprios na literatura e imprimiu a sua originalidade em um terreno que já tomavam por infértil. Voltando ao que disse Rachel de Queiroz, ideia que animou este trabalho, o romancista deu vida nova ao desmoralizado regionalismo. E quem se atreveria a reavivar assuntos passados, ainda mais após o surgimento de um escritor como Guimarães Rosa, depois de quem decretavam o fim do regionalismo? Só mesmo um contador de boas histórias como José Cândido (a fala é de Ponciano, mas se ajusta bem também ao criador): "Sou de muito inventismo, um danado em fazer render uma parolagem" (Carvalho, 1983, p.156). E tanto inventava, que acabava por dizer a verdade.

Seu tema de predileção parece ser a modernização, mas observada em sua incompletude. Assim, nas crônicas, o interesse pelas figuras decadentes, como a do major contador de histórias, já se anunciava. Também no romance de 1939, o moço Eduardo vive com o pensamento em uma época longínqua dos barões. Para Octavio Ianni, uma realidade histórico-social complexa e problemática propicia a criação de tipos, por meio dos quais a realidade se revela inteligível:

Na história do pensamento brasileiro debruçado sobre a sociedade e sua cultura, são frequentes e, às vezes, notáveis os tipos que se criam e recriam, taquigrafando a difícil e complexa realidade. Assim, a história aparece como uma coleção de figuras e figurações, ou tipos e mitos, relativos a indivíduos e coletividades, a situações e contextos marcantes, a momentos da geo-história que se registram 
metafórica ou alegoricamente. Esclarecem ou ordenam o que se apresenta complexo, contraditório, difícil, como é habitualmente a realidade histórico-social, em suas formas de sociabilidade e em seus jogos de forças sociais. (Ianni, 2000, p.60)

Do apego ao mundo dos barões e coronéis, desse passado ainda não devidamente concluído, formam-se figuras como Eduardo e Ponciano, homens em crise com seu papel social e com a temporalidade em que vivem, entre um passado de glórias, e um futuro de promessas ilusórias. Saídos de uma sociedade de quase quatro séculos de escravismo, esses protagonistas estão ainda deslocados, à procura de uma identidade em um mundo em transição. Pouco afeitos à disciplina, ao trabalho como obrigação, à formalidade, $\mathrm{e}$ vivendo uma liberdade inocente, sociabilidade solta, imprevisível, convivendo com a preguiça e a luxúria, pode-se concluir que esses heróis recuperam - buscando a definição de Ianni (2000) - as características do tipo "macunaíma", que integra o imaginário brasileiro. Há nessa recuperação do tipo macunaímico uma perspectiva bastante crítica: o preguiçoso e de vida desregrada não é mais o homem pobre e negro, trata-se agora de uma sátira ao homem branco saído de uma elite. Isso parece ser uma perspectiva subversiva no sentido de que a ideologia que cria o estereótipo do pobre preguiçoso é elitista, enquanto essa, que acusa o homem branco, é de caráter popular coerente com a época em que escreve José Cândido, marcada pela ascensão das massas.

Assim, interessa lembrar que Eduardo repudiava seu tio justamente por vê-lo como um homem trabalhador e por ter "sangue negro". No preconceito de Eduardo encontra-se o eco de um pensamento herdado do passado escravagista, que faz que o trabalho seja visto como algo aviltante e uma prática para negros. Desse modo, o ataque de José Cândido é mais incisivo à figura de Eduardo. Ponciano, por sua vez, embora se refira a seus agregados e subalternos frequentemente pela pele morena, tem amigos negros e não os despreza. Isso ocorre, conforme se discutiu, pois, apesar de ambos serem representantes de uma elite agrária e se depararem com 
conflitos econômicos, sociais e culturais bastante semelhantes em suas trajetórias, Eduardo é altamente mesquinho e despótico em relação àqueles que lhe são inferiores socialmente, enquanto Ponciano é generoso e solidário com os mais humildes e indefesos. Trata-se, portanto, de uma diferença de moral. De qualquer forma, ambos são homens brancos e elitistas apontados por vícios antes relacionados a outras camadas, o que indica a presença de uma perspectiva popular.

Já no plano da forma, demonstrou-se, pela análise das obras, que o romance de 1964 aproxima-se mais de uma cosmovisão popular por incorporar o repertório mítico e lendário, marcando seu distanciamento em relação ao de 1939, este de tendência realista. Desse modo, a despeito das semelhanças que o romance de 1964 guarda, em especial, pela manutenção da mesma ambientação rural e do caráter central de muitos dos conflitos a ela inerentes, do romance de 1939 se afasta e, por extensão, da estética dos anos 1930, não apenas por sua localização temporal, mas, principalmente, pela incorporação de uma dimensão insólita à narrativa.

Confirmada a hipótese rastreada, foi possível passar à leitura do romance pela historiografia literária. Chamou a atenção, nesse ponto, o desacordo existente entre os posicionamentos sobre a relação da obra com o regionalismo, impasse aparente sobretudo quando os críticos procuram situar o autor na tradição literária. Daí que o romance parece "deslocado" na historiografia, pois os juízos são bastante flutuantes com relação à obra e sua possível vinculação ao regionalismo. Sobre o plano mágico da narrativa, outro ponto polêmico, percebeu-se que a tendência dos autores que o discutiram foi justificá-lo pela capacidade inventiva do narrador-protagonista, como, portanto, se os episódios insólitos não passassem de invenções deliberadas ou crenças imaginárias da personagem, à semelhança dos contadores de história. Na sequência, procedeu-se à leitura pontual dos textos críticos selecionados. Destaca-se aqui, sobretudo, a importância do resgate do trabalho de Regina Zilberman, não apenas por ser o de maior fôlego encontrado sobre o assunto, mas porque, como permanece em sua primeira edição, é um estudo de 
divulgação e acesso mais restritos. Por fim, a realização desse compêndio crítico foi determinante para definir o viés de análise que se conferiu à obra.

Finalmente, a leitura que se propôs ao romance procurou situá-lo em vista de seu contexto histórico, de outras produções de José Cândido, e também em relação ao questionamento de categorias críticas capazes de potencializar sua interpretação.

Reconhecer Ponciano como a representação de aspectos de um possível retrato do Brasil da década de 1950 tornou possível reavaliar a função do mágico na obra. Dessa perspectiva, o pensamento fantasioso de Ponciano encontra correspondência com a imaginação que alicerçou as expectativas de uma nação em um momento histórico de euforia e promessas de mudança. Nesse sentido, o mais significativo foi concluir que o insólito da narrativa não consiste em uma resposta positiva a um anseio ufanista: ao contrário, a convocação do mágico à narrativa serve como instrumento de revelação das fantasias nacionais, pela denúncia do caráter ilusório do progresso repentino do país. Isso assinala a existência de uma consciência da precariedade das condições do momento histórico. O mito representado funciona, assim, como a imagem de um país rústico, selvagem e arcaico, tal como Ponciano, iludido com as ideias de civilização e progresso. Conceitos críticos que levam em conta a existência de uma dimensão alegórica em narrativas como essa confirmam a viabilidade de tal perspectiva de leitura. Assim, acredita-se que, a partir das relações estabelecidas entre o romance de José Cândido e os conceitos crítico-teóricos convocados à discussão, tenha-se promovido um avanço na forma de situar e compreender essa obra.

Essa perspectiva pauta-se na percepção geral de que os processos de modernização da América Latina carregam em si o atraso, decorrente da dependência econômica mantida em relação aos países hegemônicos. No contexto dos países periféricos do grande sistema capitalista, a modernização não significa a superação total do atraso. Ao contrário, a modernização prevê, nessas regiões, sua conservação. Países como o Brasil estiveram, por algum tempo, sob as forças de dois projetos, ambos impostos pelas metrópoles: um 
projeto modernizador, capaz de aumentar o potencial consumidor do país, como forma de ampliar o alcance do mercado estrangeiro; e outro, retrógrado, que garantia justamente a manutenção de formas arcaicas, como a escravidão, para continuar favorecendo os baixos custos da produção e, por consequência, da exportação dos produtos, de modo a sustentar a modernização dos países dominadores. No final do século XIX, essas forças contrárias, que geravam um mesmo movimento paradoxal, garantiam a capacidade do país de se aproximar do progresso técnico das metrópoles. Por outro lado, ao fazê-lo, favoreciam uma minoria bastante seleta - da qual Ponciano não faz parte -, promovendo a desigualdade social e a realidade do subdesenvolvimento.

Como o atraso, portanto, não se opõe ao progresso, os países latino-americanos vivem uma temporalidade dupla. No romance, a convivência desses dois tempos se manifesta, entre outras formas, no plano do enunciado. Em O coronel e o lobisomem, esse é o dilema de Ponciano, originário de uma estrutura social arcaica, voltada ao passado e à tradição, mas que tenta ingressar na modernidade dos centros urbanos, cujo olhar se lança ao futuro buscado nos modelos estrangeiros. $\mathrm{O}$ arcaico sobrevive também na narrativa por meio do retorno do mito, como muitos críticos apontaram. No entanto, como não há um rompimento total com o mundo arcaico, o mito não pode ser resgatado em sua integridade nas literaturas periféricas.

Desse modo, a figura do lobisomem, como apontou Bernd (1998), é emblemática desse impasse: trata-se de um ser mitológico que representa a transformação, uma espécie híbrida, meio homem, meio lobo. No entanto, o mito é cíclico, então não se deve entender que o lobisomem representa a transição do homem primitivo, do ambiente arcaico do passado, para o civilizado moderno. $\mathrm{O}$ mito da licantropia representa a exclusão social, a decadência dos valores racionais superiores, e a preponderância da irracionalidade e do instinto sobre o que há de humano e racional. O lobisomem representa a irrupção do passado e do primitivo sobre o moderno. $\mathrm{Na}$ cidade, o próprio coronel, principalmente ao final, quando ensandecido, assume a condição de um lobisomem, pois passa a ser excluído, 
evitado, marginalizado pelas pessoas. Isso ocorre também com o mestre Amaro, de Fogo Morto. Em síntese, as literaturas periféricas chamam a atenção, valendo-se do mito, para o fato de que a modernização imposta conserva a ruína. No contexto da modernidade periférica, os mundos arcaicos nunca são completamente superados. Essa parece ser a mensagem final de romances como $O$ coronel e o lobisomem.

Nesse sentido, convém levar em conta a proposição de Franco Moretti (1996), de que as literaturas periféricas revitalizaram o mito fáustico ao tratarem da modernização. Também para Ángel Rama (2004), a incorporação do mito pelas literaturas latino-americanas manifesta um sentido de resistência aos valores racionais da civilização burguesa. O Fausto de Goethe, para concretizar a modernização, vale-se de um pacto com Mefistófeles. Na América Latina, no entanto, esse pacto, compreendido alegoricamente (Moretti, 1996), ocorre apenas com uma seleta minoria, as elites responsáveis pelos acordos econômicos do país com o exterior. Ponciano, então, não é um agente do processo da modernização. É a própria matéria de que se alimenta esse processo. Seu âmbito de atuação é reduzido a uma área ínfima do país, de maneira que não passa do coronel do Sobradinho, no sentido econômico. Proprietário rural na periferia (da periferia) do capitalismo, o coronel acredita, porém, no engodo do projeto modernizador e, por isso, não resiste à derrocada. Assim, o Sobradinho pode ser tomado como um microcosmos das regiões subdesenvolvidas da América Latina, como também o são a Macondo de Márquez e os Gerais de Rosa. Enquanto se constrói no primeiro plano uma possível narrativa para a modernização latino-americana - e brasileira, em específico, conforme se discutiu no início deste capítulo -, no segundo plano, subentendida, encena-se uma narrativa do domínio das elites europeias sobre a modernização do continente latino-americano.

Sem qualquer pretensão de esgotar aqui um problema que, na verdade, acaba de ser levantado, propõe-se comparar, à guisa de conclusão, os sentidos que a figura do diabo adquire para o jagunço de Guimarães Rosa e para o coronel de José Cândido. Enquanto 
permanece a dúvida, no caso de Riobaldo, sobre a possibilidade de ter realizado um pacto com o demônio, que pode ser tomado como o mito fáustico, Ponciano, por sua vez, recusa qualquer possibilidade de pacto e parte para travar uma luta contra o pai das trevas. Essa luta, que é apenas anunciada sem se concretizar, ocorreria em um plano mágico da narrativa. Assim, o olhar pessimista de José Cândido indica que não é possível resistir ao mundo da reificação sem "pactuar com o diabo", expressão que é plurissignificativa no sentido metafórico. Em outras palavras, demonstra-se, por esse final trágico, uma visão de extremo pessimismo pela impossibilidade de conciliação entre os valores humanos e os reificadores, contrapostos definitivamente pelo capitalismo. 


\section{ANeXos}

\section{Anexo A}

\section{A guerra do Paraguai em Pessoa}

O velho Bragança - major Alfredo de Assumpção Bragança comprou cadeira cativa na minha admiração. Não tenho saudades daquelas tarde fagueiras do Casemiro de Abreu "à sombra das bananeiras debaixo dos laranjais". Nada disso. Os meus bemóis sentimentais foram todos canalizados para essa figura do tempo antigo, major da Guarda Nacional e funcionário aposentado de uma repartição pública falecida antes mesmo de ser criada. Só muitos anos depois, lendo o Rocha Pombo e o "Jornal do Comércio", é que me dei conta de que não fora o major Bragança o vencedor da guerra do Paraguai. Pois estava convencido de que o velho Bragança é que dera fim a essa história de Solano Lopes. Mesmo assim, o intrépido major da Guarda Nacional ficou com crédito na minha admiração. Vejo-o agora, com uma distância imensa de anos, contando lorotas para sua clientela. Cultivava um bigode longo, por baixo do qual, como um rio maravilhoso, passavam as melhores aventuras que já ouvi. Qual Alexandre Dumas, qual nada! Contador de histórias era Alfredo de Assumpção Bragança. À tarde, enquanto a noite se arrumava para 
entrar em ação, o major falava de suas correrias pelas campinas do Paraguai. Fôra até uma pena que a guerra com Solano Lopes fôsse tão curta. Quando êle, Alfredo Assumpção Bragança, começa a arregaçar as mangas, resolveram fechar o expediente. Fizeram feriado no pobre do Lopes. Mesmo assim, ao apagar das luzes, por baixo do pano, o velho major conseguira pegar pela unha 30 fortalezas e mais 4 cidades e meia por sobremesa. Mas regressou melancólico, cheio de rosas murchas na alma. E ficou falando a vida inteira das suas proesas, do seu cavalo branco, das suas mortandades sem fim. Onde estivesse, podiam contar que a guerra do Paraguai ai estava presente, de corpo inteiro, com tiros de canhão, gritos de comando e outros pertences. Morreu em 1939, no começo da Grande Guerra nº 2. Foi uma pena, pois estou convencido de que o major daria um jeitão nela. Pelo menos encurtaria a mortandade de vários meses, talvez anos. Quando começou a vestir a sua farda velha e empoeirada, uma porta se abriu e uma lança de vento penetrou, como aço, nas contas largas do bravo homem de armas. Vento Traiçoeiro! Se viesse de frente, como gente honesta, bem que o major o mandaria para as profundas. Mas, assim, à traição, o comedor de fortalezas não pôde fazer nada. Achou melhor morrer de verdade. E morreu na cama, cheio de sanapismos e beberagens. Partiu para os arsenais de Deus de maneira mansa, como passarinho que se afogasse em chás de erva cidreira...

CARVALHO, J. C. de. A guerra do Paraguai em pessoa. A Noite, Rio de Janeiro, 5 dez. 1951, p.5.

\section{Anexo B}

\section{Conversa sem importância}

O meu famoso amigo Lúcio Cardoso, relembrando velhas conversas de mesa de café, espalhou a nova de que tenho um romance nos estaleiros. Humildemente, como certas figuras da Bíblia, vos digo que sim. Aconteceu há muito tempo. Morava eu numa 
cidadedizinha caranguejeira de beira-mar fluminense. As máquinas de Deus fabricavam por lá, em série, os mais lindos crepúsculos e madrugadas que os meus olhos já viram. Pois êsses fins de tarde, como as minhas caixas de recordações, residiam precisamente em baixo da minha janela, entre mangericões e umas trepadeiras desmoralizadas pelo amor dos gatos. E de manhã saiam para o trabalho transformadas em madrugadas tipo Guerra Junqueiro, joviais e cantadoras. Do meu varandim, assistia ao andar da cidadezinha, que era um andar antigo, do tempo do espartilho. E havia também as noites, com um luar de velas sôltas por cima dos telhados e das pessoas. Não que fôsse luar de Copacabana, desonesto e impróprio. Nada, nada. O luar de lá era respeitoso, luar para jôgo de gamão. Mundo perdido, mundo de mentira, mas gostoso como doce feito em casa. Pois diante de tanta coisa antiga, resolvi virar Balzac municipal, muito cioso de minha gloriazinha de vinte quilômetros de extensão. E foi nessa qualidade de Balzac em férias que, muito correto, um tanto solene, procurei o diretor do "Clarim", o "arauto das aspirações locais". O seu "pince-nez" comeu, ligeiro, as fôlhas que lhe entreguei. Tossiu o seu catarrinho 1830 e fungou à maneira de 100 anos atrás. E, sem meias medidas, recusou os meus rabiscos.

- Períodos curtos. Isso cheira a anarquismo. Escreva-me em estilo terso como Herculano, como o Garrett....

Como não sabia escrever em estilo roliço, não frequentei as páginas do "Clarim”. Saí desolado. Lá fora, grande como êle só, estava o mar, indiferente a períodos longos ou estreitos. Mas esta história de estilo roliço assustou o diretor do "Clarim". Desde então começou a falar de mim. Quando apareci, certa noite, com um palitó de veludo azul, foi a pá de cal.

- Paletó de veludo azul, héim? Bem que eu dizia. O homem é anarquista. Vi logo pelo estilo períodos curtos...

Resolvi reagir. Escrevi ao facínora uma carta cerimoniosa, cheia de períodos longos. E esperei que o "Clarim" saísse. E o "Clarim" saiu, meus amigos. Mas com uma vastíssima espinafração nos meus cinquenta e nove quilos. Insinuava até que o meu nome estivera envolvido em desfalque, em Maceió, em uns negócios de navios. 
Imaginem em que situação fiquei para explicar que nunca estivera em Maceió e que em matéria de navegação nunca passara líricas viagens em barcos de regata. Mas em verdade vos digo que foi o fim. É bem certo que falei em quebramento de caras, bengalas etc. O diretor do "Clarim" contrabalançou essas ameaças vestindo a sua farda de major da Guarda Nacional. Arrumei então as malas e a cidadezinha bonita, de crepúsculos para salas de jantar, ficou para trás. Na estação, de olhar feroz, uma senhora gorda, de bigode ralo, afirmou que eu era um sujeito perigoso. Uma revolução em marcha.

- Quis até subornar o Pantaleão, do "Clarim”, vejam só.

Enfim, lá se foi o tem levando a revolução que eu era. E enquanto a maquinazinha comia os trilhos, pensei, sem mágoas e sem rancores, como seria gostoso arrumar todo aquêle mundo em páginas de livros e pedir ao bom José Olímpio que lhe desse prestígio e vida. E foi assim, num pacato trenzinho de estrada deficitária a vinte quilômetros por hora, que nasceu o meu romance. $\mathrm{O}$ balzaquinho de porão que sempre viveu em mim pulou para fora. E agora, José?

CARVALHO, J. C. de. Conversa sem importância. A Noite, Rio de Janeiro, 27 out. 1953. Ilustrada, p.27.

\section{Anexo C}

\section{O Major}

Qual que! Contador de histórias foi mesmo velho Ponciano de Azeredo Furtado, o maior patriota exaltado que já se viu em terras e águas de Campos dos Goitacases. Era a própria guerra do Paraguai em pessoa. Só muitos anos depois, lendo o Rocha Pombo e os jornais de domingo, é que me dei conta de que não foi o Major Ponciano o vencedor de Solano Lopes. Que pena! Mesmo assim, o velho ficou sempre de varanda na minha saudade. Falava forte, aos berros, como convém a um herói do seu porte. Não tinha mêdo de nada, "só de Deus Todo Poderoso". Um lobisomem, por exemplo, andava 
assombrando povo de Cruz das Almas. Pois não tivessem mêdo. Ponciano lá aparecia, por horas mortas, fardado de Major da Guarda Nacional.

\section{****}

- Onde anda êsse lobisomem?

É claro que a assombração não aparecia. E Ponciano, no outro dia, nos cafés, armava o seu teatro:

- Pois foi o Major chegar e o lobisomem aparecer. Vinha de olho em brasa. Foi quando peguei o bicho pelos chifres e gritei: "Estais em poder do Major Ponciano de Azeredo Furtado e de minhas mãos não saireis". E apertei, com fôrça, o gasganete da fera que ainda teve tempo de dizer com voz engasgada: "Tenha pena de mim, Major, pois sou um lobisomem amedrontado, corrido de cachorro, mordido de cobra. Na lua que vem termino a minha penitência e já tenho emprêgo garantido. Vou ser coletor federal”.

E Ponciano, na mesa do café, para os seus admiradores:

- Vejam só como anda êste Govêrno! Um lobisomem coletor federal...

O Major era especialista nessas pequenas faxinas de coragem. Cultivava um bigode longo, por baixo do qual, como rio maravilhoso, passavam as melhores aventuras que já ouvi. À tarde, enquanto a noite se arrumava para subir, Ponciano se abria em história da Guerra do Paraguai. Êsse, sim, era o seu número maior, a sua ópera. Foi até uma pena que a briga com Solano Lopes tivesse sido tão curta! Quando êle, Ponciano de Azeredo Furtado, começou a arregaças as mangas, fizeram ponto final no assunto. Mesmo assim, ao apagar das luzes, por baixo do pano, o velho Major ainda conseguiu pegar na unha trinta fortins e umas poucas de cidades por sobremesa... 
Mas regressou melancólico, cheio de rosas murchas na alma. Não pudera exercer o seu patriotismo a todo pano. E ficou falando a vida inteira em suas proezas, no seu cavalo branco, nas suas mortandades sem fim, Onde estivesse, podiam contar, estava a Guerra do Paraguai em corpo inteiro, com tiros de canhão, gritos de comando e outros pertences. Morreu em 1914, no comêço da outra Grande Guerra. Foi uma pena. Pelo menos, encurtaria a mortandade de vários anos. Quando começou a vestir a sua farda velha e empoeirada, eis que uma porta se abre e uma lança de vento penetrou nas costas largas do bravo homem de armas. Vento traiçoeiro. Se viesse de frente, com bravura e honestidade, bem que o Major o mandaria para as profundas do inferno. Mas, assim, à traição, o comedor de fortalezas não pôde fazer nada. Achou melhor morrer de verdade. E morreu na cama, cheio de sanapismos e beberagens. Partiu para os arsenais de Deus de maneira mansa. Um passarinho que se afogasse em chá de erva doce...

CARVALHO, J. C. de. O Major. Jornal do Brasil, Rio de Janeiro, 16 ago. 1958. $1^{\circ}$ Caderno, p.3. 


\section{REFERÊNCIAS BIBLIOGRÁFICAS}

\section{Obras do autor}

CARVALHO, J. C. de. Se eu morrer, telefone para o céu. Rio de Janeiro: José Olympio, 2010. (Sabor Literário.)

. O coronel e o lobisomem: deixados do Oficial Superior da Guarda Nacional, Ponciano de Azeredo Furtado, natural da Praça de São Salvador de Campos dos Goitacases. 53.ed. Rio de Janeiro: José Olympio, 2007.

. O coronel e o lobisomem: deixados do Oficial Superior da Guarda Na-

cional, Ponciano de Azeredo Furtado, natural da Praça de São Salvador de Campos dos Goitacases. 33.ed. Rio de Janeiro: José Olympio, 1983.

. Olha para o céu, Frederico!: romance acontecido em Campos dos Goitacases nos dias do gramofone. 4.ed. Rio de Janeiro: José Olympio, 1974. (Coleção Sagarana.)

. Ninguém mata o arco-íris. Rio de Janeiro: José Olympio, 1972.

. O Major. Jornal do Brasil, Rio de Janeiro, 16 ago. 1958. $1^{\circ}$ Caderno, p.3.

. [Carta] 20 nov. 1957, Rio de Janeiro [para] SODRÉ, Nelson Werneck.

1f. Anuncia novo romance. Disponível em: http://objdigital.bn.br/acervo_digital/div_manuscritos/mss1353556.jpg. Acesso em: 18 abr. 2013.

. Conversa sem importância. A Noite, Rio de Janeiro, 27 out. 1953. Ilustrada, p.27.

. A guerra do Paraguai em pessoa. A Noite, Rio de Janeiro, 5 dez. 1951, p.5. 


\section{Obras sobre o autor}

BACEGA, M. A. (Org.). José Cândido de Carvalho: seleção de textos, notas, estudos biográfico, histórico e crítico e exercícios. São Paulo: Abril Educação, 1983. (Literatura Comentada.)

BARBIERI, I. Situação e perspectivas. In: COUTINHO, A. (Org.). A literatura no Brasil. 4.ed. rev. e ampl. São Paulo: Global, 1997. v.5, p.560-80.

BARBOSA, A. O romance regionalista brasileiro. Brasília: LGE, 2006.

BENTANCUR, P. Humor e magia. Rascunho, Curitiba, n.106, fev. 2009, p.11-2.

BERND, Z. O maravilhoso como ponto de convergência entre a literatura brasileira e as literaturas do Caribe. Revista Brasil de literatura. 1998. Disponível em: http://revistabrasil.org/revista/abertura.html. Acesso em: 2 jun. 2012. BOSI, A. História concisa da literatura brasileira. 2.ed. São Paulo: Cultrix, 1974. BRASIL, A. A nova literatura brasileira - O romance, a poesia, o conto. In: COUTINHO, A. (Dir.). A literatura no Brasil. 4.ed. rev. e ampl. São Paulo: Global, 1997. p.245-74.

A nova literatura. v.1: O Romance. Rio de Janeiro: Americana, 1973.

(História crítica da literatura brasileira.)

. Nós temos melhor. O Globo, Rio de Janeiro, 27 dez. 1969. Arte e crítica, ano I, n.22, p.9.

BUENO, L. Uma história do romance de 30. São Paulo: Edusp; Campinas: Unicamp, 2006.

BURLÁ, E. Três novos. Dom Casmurro, Rio de Janeiro, 6 jan. 1940. Crítica, p.6.

CAMPOS, G. O coronel e o lobisomem. Última Hora, 20 jul. 1963, p.3.

CASTELLO, J. A. A literatura brasileira: origens e unidade (1500-1960). São Paulo: Edusp, 1999. v.2.

COELHO, N. N. O coronel e o lobisomem. In: O ensino da literatura. São Paulo: FTD, 1966. p.339-51.

CRISTÓVÃO, F. O sertão como espaço mágico, fantástico e sobrenatural. Letras de hoje, Porto Alegre, n.91, p.7-15, mar. 1993.

DACANAL, J. H. Nova narrativa épica no Brasil. 2.ed. Porto Alegre: Mercado Aberto, 1988. . Realismo mágico. Porto Alegre: Movimento, 1970.

ÉLIS, B. Tendências regionalistas no modernismo. In: ÁVILA, A. (Org.). O modernismo. São Paulo: Perspectiva, 1975. p.87-102.

FARIA NETTO, J. L. José Cândido, onde está Frederico?. Jornal do Brasil, Rio de Janeiro, 9 mar. 1974. Suplemento Livro, p.3. 
FERNANDES, C. A. O coronel e o lobisomem: uma abordagem sócio-interacional. São Paulo: Annablume, 1999.

Considerações sobre $O$ coronel e o lobisomem. Linguagem: estudos e pesquisas. Revista do Departamento de Letras da UFG, Catalão, v.1, n.1, p.27-36, 1997.

FERREIRA, A. José Cândido de Carvalho, vida e obra. Campos dos Goytacazes: Faculdade de Direito de Campos, 2004.

MAIA, A. Romancista esquecido. A Noite, Rio de Janeiro, 11 mar. 1952, p.3.

MARCHEZAN, L. G. Fogo morto e O coronel e o lobisomem: duas vertentes de uma poética da loucura na literatura brasileira. In: MARCHEZAN, L. G.; TELAROLLI, S. (Org.). Cenas literárias: a narrativa em foco. Araraquara: UNESP, FCL, Laboratório Editorial; São Paulo: Cultura Acadêmica, 2002. p.39-56.

MARTINS, L. O coronel e o lobisomem. O Estado de S. Paulo, São Paulo, 3 dez. 1970. Caderno Geral, Crônica, p.15.

MARTINS, W. O personagem quixotesco. O Estado de S. Paulo, São Paulo, 6 jun. 1971. Suplemento Literário, p.4.

. Uma obra-prima. In: CARVALHO, J. C. de. O coronel e o lobisomem. 3.ed. Rio de Janeiro: José Olympio, 1970. p.xviii-xxiii. (Coleção Sagarana.) . Uma obra-prima. O Estado de S. Paulo, São Paulo, 11 jul. 1964. Suplemento Literário, p.2.

MIRANDA, T. de. O louvor do lobisomem. Folha de S. Paulo, São Paulo, 2 jan. 1971. Ilustrada, p.14.

MIYAZAKI, T. Y. Um tema em três tempos. Revista de Letras, São Paulo (UNESP), v.28, p.27-35, 1988.

MIYAZAKI, T. Y.; MARÍNEZ, J. H. de. O romance de José Cândido de Carvalho. Revista de Letras, São Paulo (UNESP), v.17, p.39-61, 1975.

NEJAR, C. História da literatura brasileira: da carta de Caminha aos contemporâneos. São Paulo: Leya, 2011.

NINA, C. ABC de José Cândido de Carvalho. Rio de Janeiro: José Olympio, 2011.

OLIVEIRA, F. de. José Cândido de Carvalho. In: Literatura e civilização. Rio de Janeiro: DIFEL/MEC, 1978. p.83-6.

PIRES, A. D. Trilhas do romance brasileiro da segunda metade do século XX. Itinerários, v.7, p.47-64, 2008.

POLESE, E. da S. No mato brabo da ficção: estudo sobre José Cândido de Carvalho. 2005. 115f. Dissertação (Mestrado em Letras). UFPR, Curitiba, 2005.

PROENÇA, M. C. Romance definitivo. In: CARVALHO, J. C. de. O coronel e o lobisomem. 3.ed. Rio de Janeiro: José Olympio, 1970. p.xii-xvi. (Coleção Sagarana.) 
RODRIGUES, M. H. Antecedentes conceituais e ficcionais do realismo mágico no Brasil. Revista Letras, UFPR, Curitiba, n.79, p.119-35, set./dez. 2009.

SALES, H. Boa noite, meu coronel!. In: CARVALHO, J. C. de. O coronel e o lobisomem: deixados do Oficial Superior da Guarda Nacional, Ponciano de Azeredo Furtado, natural da Praça de São Salvador de Campos dos Goitacases. 33.ed. Rio de Janeiro: José Olympio, 1983. p.305-15.

SANTINI, J. Um mundo dilacerado entre o riso e a ruina: o humor na literatura regionalista brasileira. 2007. 259f. Tese (Doutorado em Estudos Literários). UNESP, Araraquara, 2007.

SENDRA, A. P.; RANGEL, I. R. da G. "Olha para o céu, Frederico!" entre a memória e a ficção: uma possível releitura de José Cândido de Carvalho. In: Encontro Nacional de Professores de Letras e Artes, 5., 2011, Campos dos Goytacazes. Anais... 2011. Campos dos Goytacazes: Essentia, 2011. p.1-13. Disponível em: http://www.essentiaeditora.iff.edu.br/index.php/ enletrarte/article/view/2036/1192. Acesso em: 14 ago. 2013.

SODRÉ, N. W. História da literatura brasileira. 7.ed. atual. São Paulo: DIFEL, 1982.

SOUZA, E. P. de. O quixotesco em Fogo Morto e O Coronel e o Lobisomem. 2010. 148f. Tese (Doutorado em Estudos Literários). UNESP, Araraquara, 2010.

VIEIRA, C. J. O lobisomem do coronel Ponciano. 1984. 142f. Dissertação (Mestrado). UNESP, São José do Rio Preto, 1984.

ZILBERMAN, R. Do mito ao romance: tipologia da ficção brasileira contemporânea. Caxias do Sul: Universidade Caxias do Sul / Porto Alegre: Escola Superior de Teologia São Lourenço de Brindes, 1977.

\section{Entrevistas e depoimento do autor}

CARVALHO, J. C. de. Depoimento à ABL. [jun. 1987]. Depoimento concedido a Maria Cláudia de Mesquita e Bonfim. In: FERREIRA, A. José Cândido de Carvalho, vida e obra. Campos dos Goytacazes: Faculdade de Direito de Campos, 2004. p.64-122.

. Às vezes penso que o Brasil não existe. [set. 1984]. Entrevista concedida a Bella Jozef. O Estado de S. Paulo, São Paulo, 30 set. 1984. Caderno Cultura, p.11-2.

. Especialista em lobisomem. [jul. 1982]. Depoimento concedido a Maria Aparecida Bacega. In: BACEGA, M. A. José Cândido de Carvalho: 
seleção de textos, notas, estudos biográfico, histórico e crítico e exercícios. São Paulo: Abril Educação, 1983. p.3-8. (Literatura Comentada.)

CARVALHO, J. C. de. Campista, um sinônimo de bairrista. Jornal do Brasil, Rio de Janeiro, 26 jan. 1975. Caderno RJ, p.1.

. José Cândido de Carvalho, o acadêmico: detesto pessoas arrumadinhas. O Globo, Rio de Janeiro, 23 mai. 1974. Caderno Cultura, p.33.

. A campanha silenciosa de JCC por uma vaga na Academia. Diário de Notícias, Rio de Janeiro, 16 set. 1973. Escolar, p.22-3.

. José Cândido de Carvalho - Literatura compensa quem não conseguiu atravessar o Rubicão. [set. 1971] O Globo, Rio de Janeiro, 11 set. 1971. Segunda seção, p.2.

. O coronel e o lobisomem. [jun. 1964] Entrevista concedida a Eneida de Morais. Diário de Notícias, Rio de Janeiro, 28 jun. 1964. Suplemento Literário, p.2.

\section{Bibliografia geral}

AGUIAR E SILVA, V. M. de. O romance: história e sistema de um gênero literário. In: Teoria da literatura. 8.ed. Coimbra: Almedina, 1991. v.1, p.671-786.

AGUIAR, F.; RODRIGUES, J. (Orgs.). Ángel Rama: um transculturador do futuro. Belo Horizonte: UFMG, 2013. (Humanitas.)

AGUILAR, G. Ángel Rama y Antonio Candido: salidas del modernismo. In: MANZONI, C. (Org.). Violencia y silencio: literatura latinoamericana contemporánea. Buenos Aires: Corregidor, 2005. p.101-26.

ALMEIDA, J. M. G. de. A tradição regionalista no romance brasileiro (18571945). 2.ed. Rio de Janeiro: Topbooks, 1999.

ANTUNES, L. Z. Teoria da narrativa: o romance como epopéia burguesa. In: . (Org.). Estudos de literatura e linguística. São Paulo: Arte \& Ciência; Assis: Curso de pós-graduação em Letras-UNESP, 1998, p.179-220.

ARAÚJO, H. H. de. A tradição do regionalismo na literatura brasileira: de pitoresco à realização inventiva. Revista Letras, Curitiba, Ed. UFPR, n.74, p.119-32, jan./abr. 2008.

ARENDT, J. C. Contribuições alemãs para o estudo das literaturas regionais. Pandaemonium, São Paulo, n.17, jul. 2011, p.217-38. Disponível em: www. fflch.usp.br/dlm/alemao/pandaemoniumgermanicum. Acesso em: 10 abr. 2012. 
ARENDT, J. C. Do nacionalismo romântico à literatura regional: a região como pátria. Revista da ANPOLL, n.28, p.175-94, jul./dez. 2010. Disponível em: http://www.anpoll.org.br/revista/index.php/rev/article/viewFile/164/177. Acesso em: 10 abr. 2012.

BAKHTIN, M. Epos e romance: sobre a metodologia do estudo do romance. In: Questões de literatura e de estética: a teoria do romance. Trad. Aurora F. Bernadini et al. 4.ed. São Paulo: Editora Unesp, 1998. p.397-428.

BENJAMIN, W. O narrador. In: Textos escolhidos - Benjamin, Horkheimer, Adorno, Habermas. 2.ed. Trad. José Lino Grünnewald et al. São Paulo: Abril Cultural, 1983. p.57-74. (Os pensadores, XLVIII.)

BOJUNGA, C. JK: o artista do impossível. São Paulo: Objetiva, 2001. .JK: a imaginação no poder. Entrevista concedida a IHU on-line. [20--]. Disponível em: http://amaivos.uol.com.br/amaivos09/noticia/noticia. asp?cod_noticia $=6481 \&$ cod_canal $=34$. Acesso em: 23 nov. 2013 .

BOSI, A. Céu, inferno. In: __ Céu, inferno: ensaios de crítica literária e ideológica. São Paulo: Ática, 1988. p.10-32.

BÜRGER, P. Teoria da vanguarda. Trad. José Pedro Antunes. São Paulo: Cosac Naify Portátil, 2012.

CANDIDO, A. Literatura e sociedade: estudos de teoria e história literária. 12.ed. Rio de Janeiro: Ouro sobre Azul, 2011.

. A experiência hispano-americana de Antonio Candido. [set. 2004]. Entrevista concedida a Pablo Rocca. Literatura e sociedade, São Paulo, n.12, p.18-27, 2009.

. Formação da literatura brasileira: momentos decisivos. 1750-1880. Rio de Janeiro: Ouro sobre Azul, 2006.

. Textos de intervenção. Vinícius Dantas. (Org.). São Paulo: Editora 34; Duas Cidades, 2002.

. Literatura, espelho da América? Remate de Males, número especial, Campinas, p.105-13, 1999.

. Jagunços mineiros de Cláudio a Guimarães Rosa. In: . Vários escritos. 3.ed. rev. e ampl. São Paulo: Duas Cidades, 1995. p.147-79.

. O olhar crítico de Ángel Rama. In: Recortes. São Paulo: Companhia das Letras, 1993. p.140-7.

. A educação pela noite e outros ensaios. 2.ed. São Paulo: Ática, 1989.

O homem dos avessos. In: Tese e antítese. 3.ed. São Paulo: Companhia Ed. Nacional, 1978. p.119-39.

CARVALHO, A. L. C. de. Foco narrativo e fluxo de consciência: questões de teoria literária. São Paulo: Pioneira, 1981. 
CARVALHO, J. M. de. As metamorfoses do coronel. Jornal do Brasil, Rio de Janeiro, 6 mai. 2001, p.4. Disponível em: http://www.ivnl.com.br/download/jose_murilo_jornal_do_brasil_2001.pdf. Acesso em: 3 abr. 2013.

Mandonismo, coronelismo, clientelismo: uma discussão conceitual. Dados, Rio de Janeiro, v.40, n.2, 1997. Disponível em: http://www.scielo. br/scielo.php?script=sci_arttext\&pid=S0011-52581997000200003\&lng= en\&nrm=iso. Acesso em: 3 abr. 2013.

CHIAMPI, I. O Realismo Maravilhoso. São Paulo: Perspectiva, 1980.

CHIAPPINI, L. Do beco ao belo: dez teses sobre o regionalismo na literatura. Estudos Históricos, Rio de Janeiro, v.8, n.15, p.153-9, 1995.

. Velha praga? Regionalismo literário brasileiro. In: PIZARRO, A. (Org.). América latina: palavra, literatura e cultura. v.2. São Paulo: Memorial; Campinas: Editora da UNICAMP, 1994. p.665-702.

CORPAS, D. Transcendência do regional e modo de ser jagunço: observações de Antonio Candido sobre Grande sertão: veredas. Itinerários, Araraquara, n. 25, p.65-85, 2007.

. O jagunço somos nós: visões do Brasil na crítica de Grande Sertão: veredas. 2006. 270f. Tese (Doutorado em Teoria Literária). UFRJ, Rio de Janeiro, 2006.

COSTA, F. M. da. A realidade é fantástica. O Globo, Rio de Janeiro, 27 dez. 1969. Arte e crítica, ano I, n.22, p.9.

COUTINHO, E. F. Grande Sertão: Veredas - Travessias. São Paulo: É Realizações, 2013. (Biblioteca Textos Fundamentais.)

COVIZZI, L. M. O insólito em Guimarães Rosa e Borges. São Paulo: Ática, 1978. (Ensaios, 49.)

CUNHA, R. B. Transculturação narrativa: seu percurso na obra crítica de Ángel Rama. São Paulo: Humanitas, 2007.

DACANAL, J. H. A roça imigrante e o sertão mineiro: do mítico-sacral ao lógico-racional. 2008. 124f. Tese (Doutorado em Literatura Brasileira). UFGRS, Porto Alegre, 2008.

. O romance de 30 e os primórdios do capitalismo industrial. In: APPEL, J. C. et al. O romance de 30. Porto Alegre: Movimento, 1983.

ECO, U. Do modo de formar como engajamento para com a realidade. In: Obra aberta. São Paulo: Perspectiva, 1968. p.227-77.

EAGLETON, T. Teoria da literatura: uma introdução. Trad. Waltensir Dutra. São Paulo: Martins Fontes, 2003.

FANTINI, M. Guimarães Rosa: fronteiras, margens, passagens. 2.ed. Cotia: Ateliê Editorial; São Paulo: Editora Senac São Paulo, 2008.

. Heterogeneidade, transculturação, hibridismo: a terceira margem da cultura latino-americana. In: CHAVES, R.; MACÊDO, T. (Orgs.). 
Literaturas em movimento: hibridismo cultural e exercício crítico. São Paulo: Arte \& Ciência, 2003. p.51-65.

FERNANDES, F. A revolução burguesa no Brasil: ensaio de interpretação sociológica. 2.ed. Rio de Janeiro: Zahar, 1976.

FIGUEIREDO, E. (Org.). Conceitos de literatura e cultura. Juiz de Fora: UFJF, 2005. FISCHER, L. A. Uma reflexão sobre a formação regional. In: ARAÚJO, H. H. de; OLIVEIRA, I. T. de. (Orgs.). Regionalismo, modernização e crítica social na literatura brasileira. São Paulo: Nankin, 2010. p.189-204.

FLORA, L. Bildungsroman. In: E-Dicionário de Termos Literários (EDTL). Coord. de Carlos Ceia, [20--]. Disponível em: http://www.edtl.com.pt. Acesso em: 27 jul. 2013.

FREYRE, G. O manifesto de 1926/1952. In: TELES, G. M. (Org.). Vanguarda europeia e modernismo brasileiro: apresentação dos principais poemas, manifestos, prefácios e conferências vanguardistas, de 1857 a 1972. 17.ed. Petrópolis: Vozes, 1997. p.344-5.

FUNDAÇÃO BIBLIOTECA NACIONAL. A Noite. [s.d.]. Disponível em: http://hemerotecadigital.bn.br/artigos/noite. Acesso em: 3 de mai. 2013.

GALVÃO, W. N. Sobre o Regionalismo. In: Mínima mímica: ensaios sobre Guimarães Rosa. São Paulo: Companhia das Letras, 2008. p.91-118. . Anotações à margem do regionalismo. Literatura e sociedade, São Paulo, v.5, p.45-55, 2000.

GAMA, M. F. R. "Plástico e contraditório rascunho": a autorrepresentação de João Guimarães Rosa. 2013. 332f. Tese (Doutorado em Letras). USP, São Paulo, 2013.

GARBUGLIO, J. C. Fôlego de gato (o regionalismo e suas versões). Acta Semiotica et Linguistica, São Paulo, 1979, p.41-6.

. Rosa em dois tempos. São Paulo: Nankin, 2005.

GARCÍA MÁRQUEZ, G. El coronel no tiene quien le escriba. 17.ed. Buenos Aires: Debolsillo, 2012. (Contemporánea.)

GIL, F. C. A crítica e o romance rural. Revista de Letras, São Paulo, v.48, n.1, p.85-100, jan./jun. 2008.

- Contribuições da crítica latino-americana para o estudo do romance rural brasileiro. IPOTESI, Juiz de Fora, v.12, n.1, p.181-96, jan./jul. 2008. HEGERFELDT, A. Contentious contribution: Magical realism goes British. Janus Head Journal, Pittsburg, v.5, n.2, p.62-86, 2002.

HOUAISS, A. Dicionário eletrônico Houaiss da língua portuguesa. Versão monousuário 3.0. Rio de Janeiro: Objetiva. 2009.

IANNI, O. Enigmas da modernidade-mundo. 3.ed. Rio de Janeiro: Civilização Brasileira, 2003. 
IANNI, O. Tipos e mitos do pensamento brasileiro. Sociologias, Porto Alegre, ano 4, n.7, p.178-87, jan./jun. 2002.

O realismo mágico. In: . Ensaios de sociologia da cultura. Rio de Janeiro: Civilização Brasileira, 1991. p.54-73.

IMPRENSA OFICIAL. Diário Oficial do Estado do Rio de Janeiro. [s.d.]. Disponível em: http://pt.io.gov.mo/Links/record/498.aspx. Acesso em: 25 abr. 2013.

IPEA. Nelson Werneck Sodré - Perfil. Desafios do Desenvolvimento. Brasília, ano 8, n.68, p.85, out. 2011. Disponível em: http://www.ipea.gov.br/ desafios/images/stories/PDFs/desafios068_completa.pdf. Acesso em: 1 fev. 2014.

KERBAUY, M. T. M. A morte dos coronéis: política interiorana e poder local. Araraquara: FCL, Laboratório Editorial, UNESP; São Paulo: Cultura Acadêmica, 2000.

LAFETÁ, J. L. 1930: a crítica e o modernismo. 2.ed. São Paulo: Duas Cidades; Editora 34, 2000.

LAJOLO, M. Regionalismo e história da literatura: quem é o vilão da história? In: FREITAS, M. C de. Historiografia brasileira em perspectiva. 6.ed. São Paulo: Contexto, 2007. p.297-327.

LEAL, J. C. A natureza do conto popular. Rio de Janeiro: Conquista, 1985.

LEAL, V. N. Coronelismo, enxada e voto: o município e o regime representativo no Brasil. 7.ed. São Paulo: Companhia das Letras, 2012.

LEONEL, M. C.; SEGATTO, J. A. Fiçção e ensaio: literatura e história no Brasil. São Carlos: EdUFSCar, 2012.

MACIEL, M. E. de S. A eugenia no Brasil. Anos 90 - Revista do Programa de Pós-Graduação em História da UFRGS, Porto Alegre, v.7, n.11, p.121-30, jul. 1999.

MACHADO DE ASSIS, J. M.. Notícia da atual literatura brasileira - Instinto de nacionalidade. In: Obra completa. v.3. Rio de Janeiro: Nova Aguilar, 1979. p.801-9.

MARCHEZAN, L. G. Literatura e regionalismo. In: SEGATTO, J. A.; BALDAN, U. Sociedade e literatura no Brasil. São Paulo: Editora UNESP, 1999. p.79-90.

MARTINS, W. A prática da teoria. O Estado de S. Paulo, São Paulo, 15 ago. 1971. Suplemento Literário, p.4.

MOREIRAS, A. A exaustão da diferença: a política dos estudos culturais latino-americanos. Trad. Eliana Lourenço de Lima Reis; Gláucia Renate Gonçalves. Belo Horizonte: UFMG, 2001.

MORETTI, F. The World System from Goethe to Garcia Marquez. London; New York: Verso, 1996. 
NEEDELL, J. Belle Époque tropical: sociedade e cultura de elite no Rio de Janeiro na virada do século. Trad. Celso Nogueira. São Paulo: Companhia das Letras, 1993.

A ascensão do Fetichismo Consumista. Revista brasileira de Ciências Sociais, São Paulo, v.3, n.8, p.1-20, out. 1988. Disponível em: www.anpocs. org.br/portal/publicacoes/rbcs_00_08/rbcs08_03.htm. Acesso em: 1 set. 2013.

NEJAR, C. Carlos Nejar comenta sua "História da literatura brasileira". Entrevista concedida a Miguel Conde. O Globo. Blogs. Disponível em: http:// oglobo.globo.com/blogs/prosa/posts/.

2011/03/12/carlos-nejar-comenta-sua-historia-da-literatura-brasileira-368216.asp. Acesso em: 11 set. 2013.

PALMA, D. Gramofones e Gadgets para os lares do Brasil: consumo, cultura e tecnicismo na revista $O$ Echo (1902-1918). Projeto História: revista do Programa de Pós-Graduados em História e do Departamento de História da PUC de São Paulo. São Paulo: EDUC, n. 43 (Música e Artes), p.24972, jul./dez. 2011. Disponível em: http://revistas.pucsp.br/index.php/ revph/article/view/7738. Acesso em: 30 ago. 2013.

PARANHOS, P. O açúcar no norte fluminense. Histórica: revista on-line do Arquivo Público do Estado de São Paulo. São Paulo, n.8, p.1-10, mar. 2006. Disponível em: http://www.arquivoestado.sp.gov.br/historica/edicoes_anteriores/pdfs/historica08.pdf. Acesso em: 10 ago. 2013.

PELINSER, A. T. Olhares sobre o regionalismo literário brasileiro: uma perspectiva de estudo. Revista Antares - Letras e Humanidades, Caxias do Sul, n.4, p.106-20, jul./dez. 2010.

PELLEGRINI, T. Regiões, margens e fronteiras: Milton Hatoum e Graciliano Ramos. In: Despropósitos: estudos de ficção brasileira contemporânea. São Paulo: Annablume; FAPESP, 2008. p.117-36.

Milton Hatoum e o regionalismo revisitado. Luso-Brazilian Review, Wisconsin, v.41, n.1, p.121-38, 2004.

PEREIRA, M. R. Regionalismo revisitado. In: CAIRO, L. R. et al. (Org.). Dispersa memória. Assis: Faculdade de Ciências e Letras - UNESP, 2009. p.61-73.

PERRONE-MOISÉS, L. Vira e mexe, nacionalismo: paradoxos do nacionalismo literário. São Paulo: Companhia das Letras, 2007.

POZENATO, J. C. O regional e o universal na literatura gaúcha. Porto Alegre: Movimento - SEC, 1974.

RAMA, Á. Transculturación narrativa em América Latina. 4.ed. México: Siglo XXI, 2004. 
RAMA, Á. Ángel Rama: literatura e cultura na América Latina. Flávio Aguiar; Sandra Guardini T. Vasconcelos (Orgs.). Trad. Raquel La Corte dos Santos; Elza Gasparotto. São Paulo: EDUSP, 2001.

. Ángel Rama y Antonio Cornejo Polar: tradición y ruptura en América Latina. Entrevista concedida a Beatriz Sarlo. Punto de vista, Buenos Aires, n.8, p.10-4, mar.-jun., 1980.

RAMOS, G. Alexandre e outros heróis. 33.ed. Rio de Janeiro, São Paulo: Record, 1991a.

São Bernardo. 57.ed. Rio de Janeiro: Record, 1991b.

RASPE, R. E. As aventuras do Barão de Munchausen. Trad. Ana Goldberger; Ilust. Gustave Doré. São Paulo: Iluminuras, 2011. (Livros da Tribo.)

REIS, C.; LOPES, A. C. Dicionário de narratologia. 7.ed. Coimbra: Almedina, 2000.

REUTER, Y. Introdução à análise do romance. Trad. A. Bergaminni et al. 2.ed. São Paulo: Martins Fontes, 2004.

RIBEIRO, D. As Américas e a civilização: processo de formação e causas do desenvolvimento desigual dos povos americanos. São Paulo: Companhia das Letras, 2007.

RICOEUR, P. Tempo e narrativa. Trad. Marina Appenzeller. Rev. téc. Maria da Penha Villela-Petit. Campinas: Papirus, 1995. v.2.

ROCCA, P. Antonio Candido: cultura, pensamento, sociedade. In: AGUIAR, F.; RODRIGUES, J. (Orgs.). Ángel Rama: um transculturador do futuro. Belo Horizonte: UFMG, 2013. (Humanitas.)

ROSA, J. G. Tutaméia: Terceiras estórias. 3.ed. Rio de Janeiro: José Olympio, 1969.

SANTIAGO, S. O entre-lugar do discurso latino-americano. In: Uma literatura nos trópicos: ensaios sobre dependência cultural. São Paulo: Perspectiva, 1978.

SANTINI, J. A formação da literatura brasileira e o regionalismo. O eixo e a roda, Belo Horizonte, v.20, n.1, p.69-85, 2011.

SCHOLLHAMMER, K. E. As Imagens do Realismo Mágico. In:

Além do visivel: o olhar da literatura. Rio de Janeiro: 7Letras, 2007. p.125-45.

SEIDINGER, G. M. Guimarães Rosa ou a paixão de contar: narrativas de Sagarana. São Paulo: Scortecci, 2004.

SPINDLER, W. Magic realism: a typolog. Forum for modern language studies, Oxford, v.39, p.75-85, 1993.

TEIXEIRA, I. Poética cultural: literatura e história. Politeia: Hist. e Soc., Vitória da Conquista, v.6, n.1, p.31-56, 2006. 
TODOROV, T. Introdução à Literatura Fantástica. São Paulo: Perspectiva, 1975.

VALERIUS, D. M. Regionalismo e crítica: uma relação conturbada. Revista Antares - Letras e Humanidades, Caxias do Sul, n.3, p.63-80, jan./jun., 2010.

VASCONCELOS, S. G. T. Homens provisórios. Coronelismo e jagunçagem em Grande sertão: veredas, SCRIPTA, Belo Horizonte, v.5, n.10, p.321-33, $1^{\circ}$ sem. 2002.

WERNECK, H. Juscelino Kubitschek - biografia. Projeto Memória 2002. Disponível em: http://www.projetomemoria.art.br/JK/. Acesso em: 22 jan. 2014.

YOUNG, T. R. Um Realismo Mágico no Brasil? Um levantamento. Mester, University of California, v.24, n.1, 1995. Disponível em: http://escholarship.org/uc/item/7h4522h7. Acesso em: 10 out. 2013.

\section{Periódicos}

A NOITE. Rio de Janeiro, 1940-1954.

CORREIO DO PARANÁ. Curitiba, 1964.

DIÁRIO CARIOCA. Rio de Janeiro, 1960-1964.

DIÁRIO DA NOITE. Rio de Janeiro, 1964.

DIÁRIO DE NOTÍCIAS. Rio de Janeiro, 1964-1973.

DOM CASMURRO. Rio de Janeiro, 1937-1942.

FOLHA DE S. PAULO. São Paulo, 1971.

JORNAL DO BRASIL. Rio de Janeiro, 1939-1975.

O ESTADO DE S. PAULO. São Paulo, 1964-1971.

O GLOBO. Rio de Janeiro, 1969-1974. 
SOBRE O LIVRO

Formato: $14 \times 21 \mathrm{~cm}$

Mancha: $23 \times 40$ paicas

Tipologia: Horley Old Style 10,5/14

1̄a edição: 2015

\section{EQUIPE DE REALIZAÇÃO}

\section{Capa}

Megaarte Design

Edição de texto

Mauricio Santana (Copidesque)

Valéria Braga Sanalios (Revisão)

Editoração eletrônica

Sergio Gzeschnik (Diagramação)

Assistência editorial

Jennifer Rangel de França 
CULTURA

ACADÊMICA

Editora 